\title{
ESCARABEOS DEL NORESTE DE HISPANIA Y DEL SUR DE LA GALIA. CATÁLOGO, NUEVOS EJEMPLARES E INTERPRETACIONES
}

\author{
SCARABS OF THE NORTHEAST OF HISPANIA AND THE SOUTH OF GAUL. \\ CATALOGUE, NEW EXAMPLES AND INTERPRETATIONS
}

MARTÍN ALMAGRO GORBEA

Real Academia de la Historia

RAIMON GRAELLS I FABREGAT

Römisch-Germanisches Zentralmuseum

\section{INTRODUCCIÓN}

La Unión Académica Internacional lleva a cabo en uno de sus programas el Corpus de Antigüedades Fenicias y Púnicas. Dentro de este programa internacional, España ha emprendido la realización del Corpus de los Escarabeos de Hispania, ya que los escarabeos son uno de los elementos más característicos de la arqueología fenicio-púnica, a lo que se añade el especial interés que ofrecen para conocer los procesos de aculturación y de interacción entre el mundo colonial y el ámbito indígena que contribuyeron a conformar el sistema socio-ideológico de las primeras estructuras gentilicias surgidas en el extremo occidental del Mediterráneo.

Estos trabajos sobre escarabeos de la antigua Hispania pretenden proseguir los buenos estudios en su día realizados por I. Gamer-Wallert y J. Padró. A esos estudios se han incorporado los hallazgos posteriores $\mathrm{y}$, además, se ha abordado una nueva perspectiva para interpretar estos interesantes materiales no ya como meros objetos egipcios o egiptizantes cuya presencia era fruto del comercio "de pacotilla" egipcio u orientalia o, quizás mejor, de exotica (Duplouy, 2006, 153; Graells, 2010, 32), sino en el marco de la interacción entre el sistema cultural colonial y el del mundo indígena, al valorar sus aspectos económicos, pero también su significado socio-ideológico, ya que la circulación de kremata $(\chi \rho \dot{\eta} \mu \alpha \tau \alpha)$ y athirmata ( $\dot{\alpha} \theta \dot{v} \rho \mu \tau \tau)$, como objetos de prestigio, jugaría un papel fundamental en los procesos de valoración y diferenciación social (Duplouy, 2006, 153), por lo que deben considerarse de manera particular más allá de su valor comercial.

Este análisis aborda los aspectos implicados al insistir en su significado religioso e ideológico. En este sentido, los escarabeos pueden considerarse casi como un "catecismo" en imágenes, ya que permite analizar qué ideas pasaban de uno a otro sistema cultural y con qué connotaciones, en qué contextos y con qué peculiaridades, tal como han puesto en evidencia desde hace ya casi 50 años los positivos resultados iconográficos de O. Keel (1972) y de este investigador con C. Ühlinger en Oriente (Keel y Ühlinger, 1992), pautas seguidas con pleno éxito en Hispania en los estudios de la escultura fenicia (Almagro-Gorbea y Torres, 2010) y de los escarabeos (id., 2009; Almagro-Gorbea et alii, 2009), que han superado de forma definitiva los prejuicios de los estudiosos que mantenían que la iconografía de los exotica tenía un valor muy limitado como fuente para el estudio de la difusión de mitos e ideas religiosas.

El término exotica es ampliamente utilizado para designar unos pocos y particulares materiales importados de procedencia mayoritariamente oriental. Pero el término no designa de manera indiscriminada todas las importaciones "orientales", se refiere en particular a las importaciones producidas en talleres del "oriente" desde una óptica helenocéntrica, en la que esos centros estarían ubicados en el Levante del Mediterráneo y en Egipto. Además del uso de esta convención, cabe señalar la advertencia realizada por A. Duplouy $(2006,153)$, que con los escarabeos podemos demostrar la imprecisión y la comodidad de usar ese término para objetos y categorías muy diversas. Los escarabeos, particularmente, han sido usados como ejemplo de un comercio "oriental" y sólo recientemente se está desarrollando una corriente, entre la que nos incluimos, en la que no sólo se demuestra una diversificación del número y naturaleza de sus distribuidores, no todos orientales, sino que se ha demostrado para algunos momentos y regiones un monopolio exclusivo no "semita", bien de griegos o de etruscos, como ocurre en el arco noroeste del Mediterráneo.

Recientes trabajos han abordado distintas síntesis parciales sobre los escarabeos aparecidos en Portugal, Extremadura y en Villaricos. Dichos trabajos han centrado su atención en ofrecer un catálogo detallado, pero dirigido a interpretar con la mayor precisión posible la recepción y el uso de estos objetos en el marco de un sistema ideológico estructurado. Su lectura motiva la 
redacción de las páginas siguientes ocupándonos de este tema en Cataluña, aunque, por coherencia y lógica arqueológica, se ha extendido a todo el Nordeste de la Península Ibérica, incluida la provincia de Castellón y el Valle del Ebro, además de las tierras del Sur de Francia ribereñas de las costas occidentales del Golfo de León, ya que se trata de un área relativamente homogénea, dado su substrato similar de Campos de Urnas y desarrollo posterior (Ruiz Zapatero, 1985; Almagro-Gorbea y Ruiz Zapatero, 1993; Graells, 2010) y también por reflejar las mismas corrientes comerciales y culturales (Graells, 2008; 2009a; 2010).

El registro arqueológico ofrece un amplio catálogo de escarabeos en Cataluña, principalmente recuperados en contextos funerarios (Graells, 2010, 55-60), más algunos procedentes de hábitats, además de algunas piezas por desgracia de procedencia desconocida. Dichos objetos gozan de una abundante bibliografía, dispersa en múltiples artículos, principalmente a cargo de J. Padró (vid. Bibliografía), aunque no exclusivamente. El conjunto supone un total de al menos 72 ejemplares, todos ellos importados desde distintos puntos del Mediterráneo y de la Península Ibérica ${ }^{1}$, lo que permite plantear una serie de consideraciones muy diferentes de las inferidas de los escarabeos de Extremadura y Portugal (Almagro-Gorbea et alii, 2009; Almagro-Gorbea y Torres, 2009), lo que confirma la personalidad del Noreste de la Península Ibérica y áreas limítrofes, así como el interés de estos análisis desde la perspectiva planteada. Por otro lado, se prosigue el método de análisis empleado para los escarabeos portugueses y extremeños, por lo que se ofrece aquí, por primera vez, un catálogo detallado de todos los escarabeos y piezas relacionadas, que incluye desde los ejemplares más antiguos, de tipo egipcio, hasta los ejemplares posteriores de tipo púnico, griego, etrusco y romano. Dicho catálogo incorpora, además, nuevos ejemplares recientemente identificados en el marco de un estudio sobre el coleccionismo de la glíptica en Cataluña (Graells, 2011), que ha permitido ofrercer un cambio sustancial respecto al mapa de distribución existente hasta hoy (Padró, 1983; Mancebo y Ferrer, 1992, fig. 3).
De este modo, el presente estudio prosigue el análisis contextualizado por regiones de todos los escarabeos y piezas relacionadas halladas en la Península Ibérica, la antigua Hispania, del que ya se han analizado los conjuntos de Portugal (AlmagroGorbea y Torres, 2009) y de Extremadura (Almagro et alii, 2009), además del conjunto procedente de la población feno-púnica de Baria, Villaricos, en Almería (Almagro Gorbea y Almagro-Gorbea, 2009), mientras están en proceso de estudio los de Gadir y las restantes colonias fenicias de la Costa del Sol, los de Andalucía Occidental y los del Sureste. Dentro de este cuadro, el presente trabajo ofrece una visión de conjunto de estos elementos en un área de la Península Ibérica de singular interés, para lo que sigue el mismo planteamiento e idéntico esquema organizativo, pues todos estos estudios van dirigidos a comprender mejor el papel de estos interesantes elementos arqueológicos, cuya visión de conjunto se pretende ofrecer en el Corpus de Escarabeos de Hispania dentro del Corpus de Antigüedades Fenicias y Púnicas que patrocina e impulsa la Unión Académica Internacional.

Antes de terminar esta introducción, queremos expresar nuestro agradecimiento a cuantos colegas, investigadores y conservadores nos han ayudado a completar las informaciones del presente catálogo, facilitándonos trabajos en curso de publicación o, incluso, piezas inéditas: Sr. B. Egea, Dr. P. Castanyer (MAC-Empúries), D. G. Clausell (Museo Municipal de Almassora), Dr. U. R. Hansson (The University of Texas at Austin y Istituto Svedese di Studi Classici a Roma), Dr. A. Oliver Foix (Castellón), Dña. M. Santos (MAC-Empúries), Dr. M. Sureda (Museu Episcopal de Vic), Prof. M. Torres (Universidad Complutense, Madrid), Dr. Q. Tremoleda (MAC-Empúries) y A D. J. A. Faro, F. Cañada, y M. Unzu, por sus valiosas informaciones inéditas sobre la necrópolis de El Castillo de Castejón, Navarra. Por ello es justo y resulta muy grato suum quique tribuere, ya que, sin su generosidad y ayuda, este trabajo hubiera sido casi imposible $\mathrm{y}$, en todo caso, sería parcial e incompleto, por lo que a su colaboración se debe en gran medida el interés que pueda ofrecer.

\footnotetext{
1. A este número podrían añadirse los 5 escarabeos ( 2 de piedra, uno en pasta vidriada y un último engarzado sobre un anillo de oro) que fueron expuestos en la exposición retrospectiva de 1867 en Barcelona ( $\mathrm{N}^{\circ}$. Inv.: 1443-1446), quizás procedentes de Ampurias, aunque la ausencia de indicaciones sobre su lugar de hallazgo nos obliga a no incluirlos en el catálogo (Catálogo, 1867, 60).
} 


\section{CATÁlOGO}

\section{CS-SOL1. La Solivella, Alcalá de Chivert, Castellón}
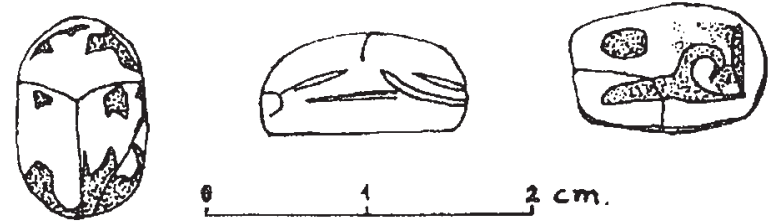

( $3 \mathrm{~cm}$.
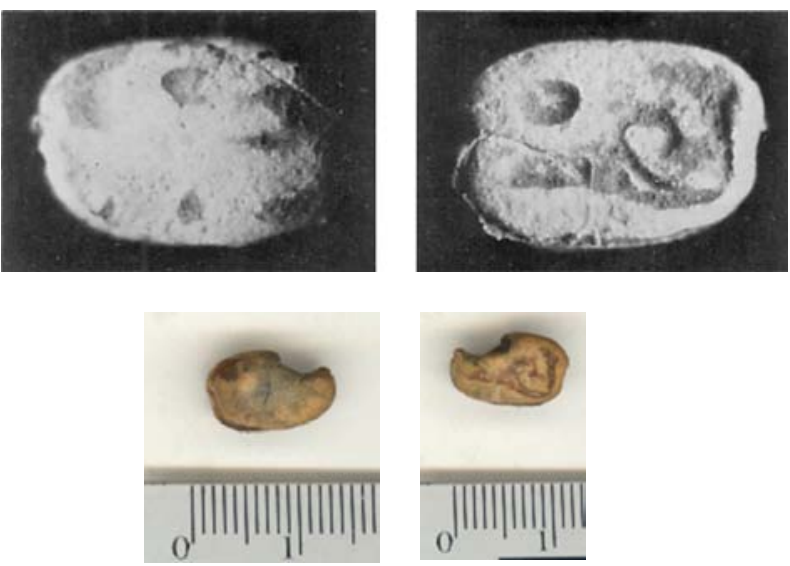

Material: Pasta de fayenza o pasta vítrea, con restos leves de vidriado verde.

Dimensiones: Largo: $12 \mathrm{~mm}$; Ancho: $8 \mathrm{~mm}$; Alto: $6 \mathrm{~mm}$.

Perforación: Longitudinal.

Soporte: No se conserva.

Tipo: Esquema dorsal de tipo IV de Newbery (1906) y

Vercoutter $(1945,72)$.

Grabado: Grabado profundo pero tosco; los laterales apenas resaltan las patas con leves incisiones.

Procedencia: Necrópolis de La Solivella 1, tumba 6.

Contexto: Aparecido en la tumba 6, con una urna cineraria de orejetas (Fletcher, 1965, 27-28, fig. 13,6), una fíbula anular de puente de alambre grueso con resorte de muelle bilateral de tipo antiguo (ibídem, 28, lám. XVIII derecha), un anillo de bronce (ibídem, 28, lám. XVIII derecha), un colgante del mismo metal (ibídem, 28, lám. XVIII izquierda) y varias cuentas de pasta vítrea (ibídem, 28, lám. XVIII superior). Esta tumba se ha fechado c. 550-400 a.C., aunque Fletcher (1965, 57-58) situó la necrópolis en el último cuarto del siglo $\mathrm{V}$ a.C., si bien es evidente que algunos materiales son más antiguos. La fíbula de la tumba corresponde al tipo Cuadrado 9 y Medellín 1, bien datado de c. 575-550 al 475-450 a.C., aunque su puente engrosado indica una datación de fines del siglo VI a la primera mitad del V a.C.

Lugar de conservación: Museo de Belles Arts de Castelló, $\mathrm{N}^{\mathrm{o}}$. Inv.: 1080

Conservación: Roto en dos fragmentos y con deterioros en su cara superior. En la actualidad ha perdido la parte superior derecha del sello, que tenía cuando se halló.

Bibliografía: Fletcher 1965, lám. XVIII, fig. 13.6; GamerWallert, 1978, 187, 280, fig. 101; Padró 1974; 1983, n ${ }^{\circ}$ 13.01, lám. LIV y LV; Graells, 2008, 79, fig. 27; 2010, 58 y $109-110$, fig. 30 y 89.

Anverso: Cuerpo del escarabajo con los élitros separados por una simple línea y cuya separación del tórax lo cons- tituyen sendas líneas convexas. La cabeza apenas parece estar modelada, lo mismo que se observa en las patas, que se limitan a meras incisiones muy esquemáticas.

Reverso: León tumbado mirando hacia la derecha; encima, signo solar circular; delante, otro signo vertical, que parece ser la pluma de Maat?

Paralelos: Gamer-Wallert $(1978,188)$ señala paralelos en Riqqa (Engelbach, 1915, lám. 18, n 35) y Náucratis (Petrie, 1886, lám. 37, $\mathrm{n}^{\circ}$ 42-45), y una pieza parecida procede de la necrópolis de Douimès, en Cartargo (Vercoutter, 1945, 202, lám. 18, no 135), pero las más parecidas proceden de Náucratis (Petrie, 1886, lám. 37, $\left.\mathrm{n}^{\circ} 45\right)$, donde se debe situar el taller de este escarabeo (Padró, 1983, 110).

Cronología: Padró (1974) fechó el escarabeo entre el 594525 a.C. y la sepultura c. 525-500 a.C. $(1983,109)$, fecha puesta en duda por Gamer-Wallert (1977, 189, n. 23), pero parece adecuada al horizonte cronológico de los escarabeos naucráticos (vid. infra) y al contexto que ofrece la sepultura en que apareció (Graells, 2010, 109-110).

Iconografía: El león tumbado fue identificado por Petrie (1889, $\left.n^{\circ} 1927-1930\right)$ con el faraón Psamético I, opinión generalmente aceptada (Padró, 1974; Gamer-Wallert, 1985 , 188), al leerlo como $R^{\prime} p^{\prime} \underline{T}^{\prime} m$, sin excluir que pueda tratarse de un criptograma simplificado (GamerWallert, 1985, 188-189).

Comentario: Puede considerarse un escarabeo del siglo VI a.C. fabricado en Náucratis, que se debe asociar a los restantes ejemplares de esa procedencia aparecidos por las costas hispanas del Mediterráneo.

\section{CS-TB1. Torrelló del Boverot, Castellón}
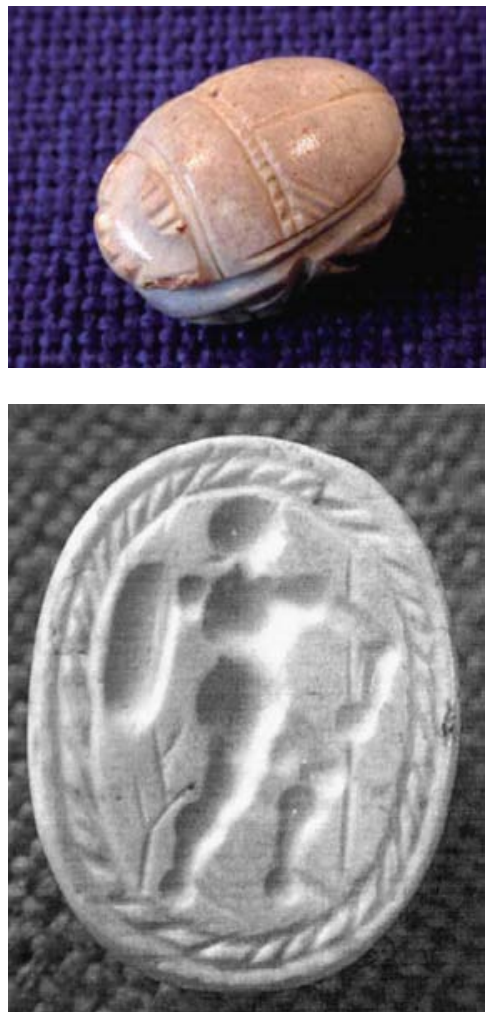
Material: El ejemplar ha sido publicado como cornalina rojiza, aunque la fotografía en color permite proponerlo como cuarzo lechoso. En cualquier caso, queda pendiente una análisis.

Dimensiones: Largo: $15 \mathrm{~mm}$; Ancho: $12 \mathrm{~mm}$; Alto: $9 \mathrm{~mm}$.

Perforación: Longitudinal.

Soporte: No se conserva.

Tipo: Escarabeo variante del tipo VI de Newberry (1906) y Vercoutter $(1945,73)$.

Grabado: Buril con aplicación de la técnica de globolo, típica de los escarabeos etruscos. Las patas talladas con cuidado.

Contexto: Recuperado en la tumba 20 de la necrópolis, casi en superficie. La necrópolis ibérica del Torrelló del Boverot, Almanzora, Castellón, situada a $300 \mathrm{~m}$. de un poblado, parece poder distinguirse de la que dio a conocer P. Bosch-Gimpera de la misma localidad, siendo más reciente la que ha sido excavada entre 1993 y 1994, como indican la cerámica griega (Claussel, 1997, 21) y los ajuares recuperados (Clausell, 1999; 2002-2003), particularmente las cerámicas áticas y una fíbula anular hispánica de tope oscilador, propia del siglo IV a.C.

Lugar de conservación: Museo Municipal de Almassora, Castellón, $\mathrm{N}^{\mathrm{o}}$. Inv.: 100056.

Conservación: Bien conservado, aunque con pequeñas melladuras y manchas de óxido de hierro.

Bibliografía: Clausell, 1999; 2002-2003.

Anverso: Cuerpo del escarabajo bien trabajado, con los élitros separados entre sí por una línea y con tres líneas oblicuas paralelas en los extremos superiores externos. Una doble línea transversal recta con trazos perpendiculares marca la separación del tórax. La cabeza aparece bien modelada en todos sus detalles.

Reverso: Guerrero desnudo hacia la derecha que adelanta su pierna izquierda en actitud de avanzar. Delante se aprecia la lanza vertical y detrás un escudo redondo y parece que cubre su cabeza con un casco hemiesférico con guardanuca. Bajo el escudo, un arbusto esquemático. Todo el campo queda rodeado por un cordón formado por dos líneas paralelas rellenas de trazos oblicuos.

Paralelos: Se trata de un típico escarabeo etrusco de la técnica de globolo evolucionada (Zazoff, 1968, 118 s.), aunque deriva de un modelo bien precisado de estilo severo (id., 55, lám. 18, nº 69).

Cronología: Siglo IV a.C.

Iconografía: El guerrero ofrece elementos iconográficos identificativos, aunque muy estilizados, que permiten interpretarlo como una figura heroica, que en el contexto cultural ibérico cabría suponer que fuera visto como representación de un Héros ktístes familiar.

Comentario: Se trata de un escarabeo etrusco, que debe relacionarse con las importaciones existentes en Hispania de bronces y otros objetos de esa procedencia (Botto y Vives, 2006; Graells, 2008; 2010), entre los que deben incluirse los escarabeos.

\section{CS-PM1. Puig de la Misericordia-1, Vinaroz, Castellón}

Material: Escaraboide de material desconocido.

Dimensiones: Desconocidas.

Soporte: Anillo de 3,5 cm de diámetro.

Dimensiones: Diámetro: $35 \mathrm{~mm}$. (con la montura).

Perforación: Desconocido.

Soporte: El escaraboide estaba montado en un soporte ( $\sin$ datos sobre su naturaleza).
Tipo: Escaraboide de forma circular.

Grabado: Indeterminado.

Procedencia: Localizada en Vinaroz en 1916 por el Sr. F. García García (noticias de prensa y Gusi, 1976, 287-288). Del ejemplar se conserva únicamente descripciones parciales (el esquema dorsal no fue atendido) y no existe tampoco ninguna documentación gráfica (A. Oliver Foix, comunicación personal, 1.7.2010).

Contexto: Desconocido.

Descripción: Objeto con "representaciones egipcias", que pudiera ser un escarabeo.

Lugar de conservación: Desconocido.

Conservación: No conocida.

Bibliografía: Padró, 1991, 443; 1977-1978, 501, nota 75; Gusi, 1976, 287-288;

Anverso: Indeterminado.

Reverso: Escena de carácter egiptizante.

Paralelos: Imposible de caracterizar con los datos disponibles.

Cronología: El yacimiento del Puig de la Misericordia presenta, como muchos de los yacimientos del norte de Castellón, una importante secuencia cronológica que inicia a finales del siglo VII a.C. y perdura hasta mediados del período Ibérico Pleno, lo que impide precisar la cronología de la pieza a partir del contexto de hallazgo, pero descarta una cronología romana o posterior.

Iconografía: Indeterminado. En cualquier caso, la montura de un escarabeo en el norte de la provincia de Castellón y en toda Cataluña es un dato interesante pues difiere de los ejemplares conocidos hasta hoy.

Comentario: Padró (1977-1978, 501, nota 75; 1991, 443) plantea la duda de que pudiera tratarse de un escarabeo de producción egipcia y propone que pudiera corresponder a una producción mediterránea, lo que resulta imposible evaluar dada la descripción disponible.

\section{CS-PN1. Puig de la Nao, Benicarló, Castellón}

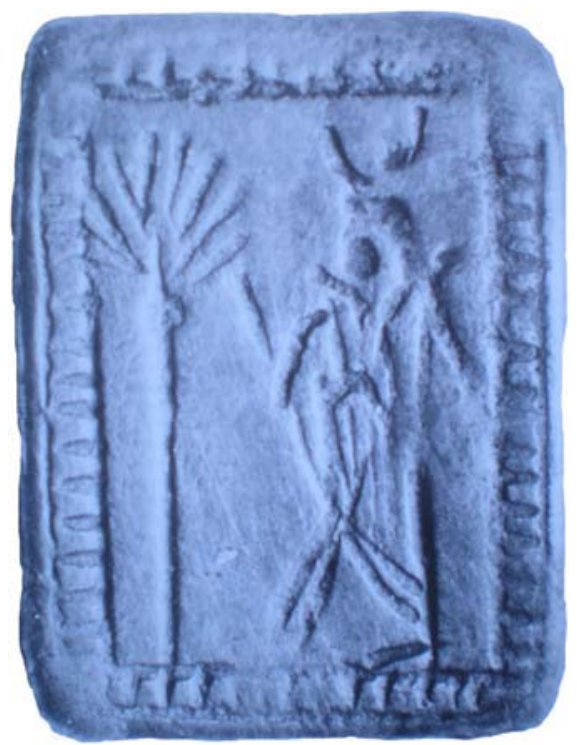

Material: Sello de plata de un anillo.

Dimensiones: Largo: $12 \mathrm{~mm}$; Ancho: $9 \mathrm{~mm}$; Alto: $1 \mathrm{~mm}$.

Peso: No indicado.

Perforación: No ofrece.

Soporte: No se conserva. 
Tipo: Sello de plata.

Grabado: Inciso a buril y muy esquemático, de estilo egiptizante de clara inspiración púnica.

Procedencia: Necrópolis del poblado ibérico del Puig de la Nao, que ocupa una importante posición estratégica sobre el litoral castellonense para controlar el comercio fenicio y colonial con la Plana de Castellón y las tierras del interior por el Puerto de Morella y el Maestrazgo (Oliver y Gusi, 1995; Oliver, 1999; 2007; Padró, 1991).

Contexto: No conocido. Procede de los saqueos en la necrópolis del Puig de la Nao realizados entre 1980 y 1981, por lo que debe proceder de una de las tumbas de la necrópolis, datadas en el siglo $\mathrm{V}$ a.C.

Lugar de conservación: Museo de Belles Arts de Castelló. $\mathrm{N}^{\circ}$. Inv.: 2348

Conservación: Buen estado de conservación con ligeros desgastes en los vértices superiores e inferior izquierdo.

Bibliografía: Oliver y Gusi, 1995, 247; Padró, 1991, 444; Oliver, 2007; Arturo Oliver Foix, comunicación personal, 1.7.2010

Descripción: Realizado con líneas incisas sobre la superficie plana de la placa mediante líneas que dan como resultado una escena muy esquemática.

Sello de plata con una escena de carácter egiptizante formada por un personaje femenino de pie, posiblemente en marcha, girado a izquierda, situado a la derecha de la escena. Parece llevar un traje largo y peluca, con cuernos sobre la cabeza y un pequeño disco solar; un trazo recto en la base indica el pié. Con la mano izquierda coge un largo astil y con la derecha otro objeto más difícil de identificar, probablemente un cetro. El personaje se dirige con la pierna derecha adelantada hacia un árbol muy esquemático situado a la izquierda en forma de palmera, pues sus ramas está hechas a base de trazos rectos abiertos en abanico, en cuya base un punto pudiera reflejar los dátiles o frutos. Toda la escena queda enmarcada por un recuadro realizado por dos rectángulos incisos relleno de líneas transversales, también incisas y realizadas desde el rectángulo interior hacia el exterior, dada la sistemática superposición de incisiones, la mayor profundidad de la incisión en ese punto y el hecho de que en muchos casos las incisiones no lleguen al rectángulo exterior.

Paralelos: Como paralelo cabe citar la representación del escarabeo del Cerro del Villar (Padró, 1991, 444; 1985, 125-127, lám. CXLII) y simios ante una palmera ofrece el escarabeo de Alcácer do Sal AS3 (Almagro-Gorbea y Torres, 2009). Más próxima resulta la representación de una divinidad femenina ante un objeto simbólico, como un tymiatherion, frecuente e escarabeos púnicos (Boardman, 1985: nº 46 s.; Padró, 1991, 444), que recientemente, han sido clasificados y muestran un amplio catálogo a partir del que puede plantearse un predominio en dicha iconografía (Boardman, 2003), aunque estos escarabeos de producción púnica ofrecen un estilo distinto al de este sello metálico. Además, es excepcional la escena de la diosa ante una palmera, que alude a mitos y ritos ancestrales, quizás todavía alusivos a la coronación real y al apoyo místico de la diosa al rey, al que da la vida eterna (Almagro-Gorbea, 2010a, 217 s.). Otro chatón en un anillo metálico con una figura inspirada en escarabeos púnicos ofrece el anillo del Castillar de Santisteban J-CS2, que evidencia el desarrollo de esta costumbre.

Cronología: La necrópolis presenta una cronología amplia, desde inicios del siglo VI a.C., por la aparición de un frag- mento de broche de cinturón de tipo Fleury, hasta avanzado el V a.C. De todos modos, la propuesta de Padró $(1991,444)$ de datar este sello en el siglo V a.C. resulta la más probable.

Iconografía: J. Padró ya propuso identificar la figura representada con la diosa Hathor, a pesar de que ni la posición ni la indumentaria apoyan esa identificación. Por ello, propuso que algunas de las líneas del cuerpo correspondieran a insignias y que la frente de la cabeza mostrara un uraeus combinado con los cuernos pschent, que permitían identificar al personaje con una representación real. En todo caso, los cuernos sobre la cabeza de la figura femenina permiten identificarla como la diosa Hathor y su asociación al Árbol de la Vida hace suponer que sea una Hathor-Astart, la diosa del Asherat o Árbol de la Vida (Keel, 1992; 1998), mito con el que se relaciona la 'Diosa de Galera' (Almagro-Gorbea, 2010a, 217 s.).

Comentario: Según opinión de J. Padró este sello de anillo sería obra de un artesano occidental (Padró, 1991, 444), aunque la ausencia de paralelos dificulta dicha afirmación. En todo caso, este sello de plata tiene el interés de evidenciar la extensión de la técnica, la iconografía y el significado de las escenas que ofrecen los sellos de los escarabeos a otros objetos de funciones similares, como los anillos metálicos con sello, hecho que debió ser más habitual de lo que hasta ahora se había documentado.

\section{T-TM1. Tossal del Moro, Piñeras, Batea, Tarragona}
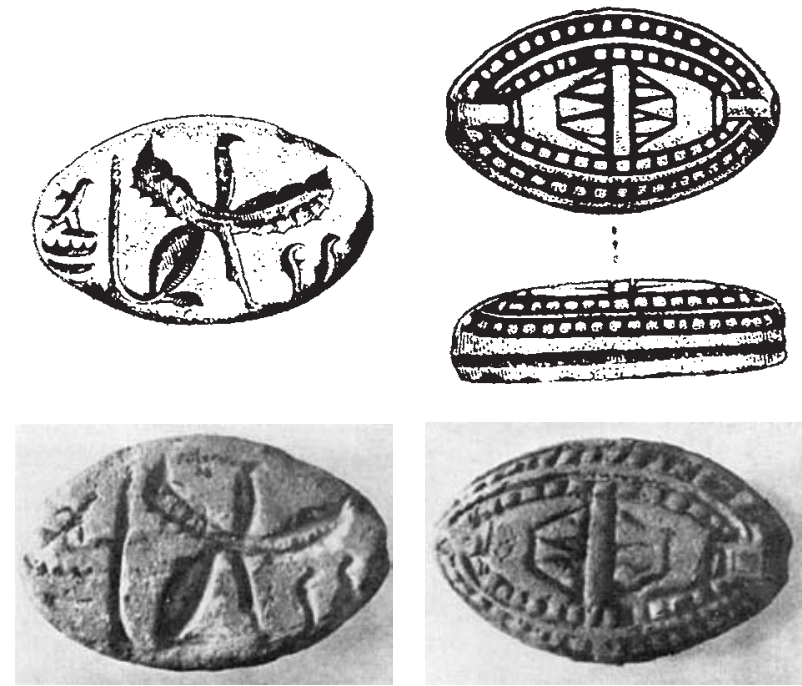

Material: Cowroide o cuenta decorada de fayenza, que conserva el vidriado verde en gran parte de la superficie.

Dimensiones: Largo: $48 \mathrm{~mm}$; Ancho: $30 \mathrm{~mm}$; Alto: $14 \mathrm{~mm}$.

Perforación: Longitudinal.

Soporte: No se conserva.

Tipo: Cuenta decorada o cowroide de forma lenticular con las superficies casi planas.

Grabado: Hecho a molde.

Procedencia: Poblado.

Contexto: Procede de las excavaciones realizadas en el yacimiento por parte de L. Pérez Temprado, sin mayores precisiones acerca de las características del mismo ni de su contexto (Arteaga et alii, 1990).

Lugar de conservación: Instituto de Arqueología de la Universidad de Barceloan. $\mathrm{N}^{\circ}$. Inv.: B148 - MACBarcelona. 
Conservación: Bien conservada.

Bibliografía: Maluquer de Motes, 1992; Gamer-Wallert, 1978, 198, fig. 108, lám. 62.a-b; Padró, 1983, 104 s., $\mathrm{n}^{\circ}$ 12.01, lám. LIII; Graells, 2009a, fig 27; 2010: fig. 30.

Anverso: Ofrece una doble flor de loto contrapuestas, separadas por dos trazos transversales y rodeadas de una doble franja reticulada.

Reverso: El sello presenta un grifo con ambas alas desplegadas, aunque también pudiera ser una esfinge con cabeza de halcón. Aparece en actitud sedente hacia la izquierda, con dos pequeños trazos delante y una inscripción jeroglífica detrás, que permite leerse como $\mathrm{Hr}{ }^{\prime} \mathrm{Mn}$ o $\mathrm{Hr}$ mnh-jb, nombre de Horus de Psamético II (Padró 1983), aunque Vercoutter leyó esta inscripción como $\mathrm{Hr} n \mathrm{nb}$ smt "Horus, Señor del Desierto (la necrópolis)" y tampoco se debe excluir un posible trigrama (Gamer-Wallert, 1978, 199).

Paralelos: Este tipo de cowroide es frecuente en Egipto, en las necrópolis de Nubia (Griffith, 1923: lám. 41, nº 15; $42, \mathrm{n}^{\circ} 18$ ), aunque perduran hasta época saita. Es obra de un taller egipcio, pero no de Náucratis, donde los grifos sedentes ofrecen un estilo y alas diferentes (Petrie, 1886, lám. 37, no 22-23, 77, 132-133).

Cronología: El momento de máximo uso de estos cowroides corresponde a la dinastía nubia, pero esta pieza debe fecharse en el siglo VI a.C., aunque no pueda atribuirse con toda seguridad a tiempos de Psamético II (595-589 a.C.).

Iconografía: Si la figura se interpreta como grifo (vid. supra), puede relacionarse con la amplia difusión de este animal durante el Periodo Orientalizante, generalmente asociado en Occidente a contextos funerarios.

Comentario: Según Vidal (1975) y Graells (2009a), el animal fantástico representado sería un grifo en vez de una esfinge, que por definición debería corresponder a un animal con cabeza humana, cuerpo de león y en algunos casos alas, en especial a partir de la dinastia XXV por influencia artística fenicia (Baquès, 1974-1975, 111). Sin embargo, el grifo presenta una cabeza de halcón, cuerpo de león con garras y se presenta siempre alado. Lo mismo puede proponerse para la representación del escarabeo de Ampurias AMP12, donde es posible que el animal representado sea más próximo a una quimera, a pesar de no ser tan clara la diferencia como en el ejemplar del Tossal del Moro. Según J. Padró (1983) correspondería a una producción naucrática, pero Gamer-Wallert $(1978,199)$ lo considera egipcio y tampoco se puede descartar una producción fenicia o chipriota (Vidal, 1975, 108 y 110).

\section{T-MM1. Mas de Mussols-1}

Material: Pasta de color amarillo con restos de barniz azul. Dimensiones: Largo: $17 \mathrm{~mm}$; Ancho: $12 \mathrm{~mm}$; Alto: $7 \mathrm{~mm}$.

Perforación: Longitudinal.

Soporte: No se conserva.

Tipo: Tipo II de Newberry y Vercoutter.

Grabado: Presenta el sello en la parte ventral, mientras que el esquema dorsal se conserva muy débilmente.

Procedencia: Procedería de la tumba $\mathrm{X}$ de la necrópolis de Mas de Mussols. Dicha tumba fue descubierta por aficionados locales y por indicaciones de los mismos $\mathrm{J}$. Maluquer cribó las tierras extraídas y completó el conjunto de materiales y escarabeos (Para una síntesis de la tumba y su análisis, Graells, 2010, 193-198).

Los escarabeos de la tumba $\mathrm{X}$ fueron hallados en dos momentos distintos: cuatro fueron hallados en las excavaciones realizadas antes de la intervención de la Universidad

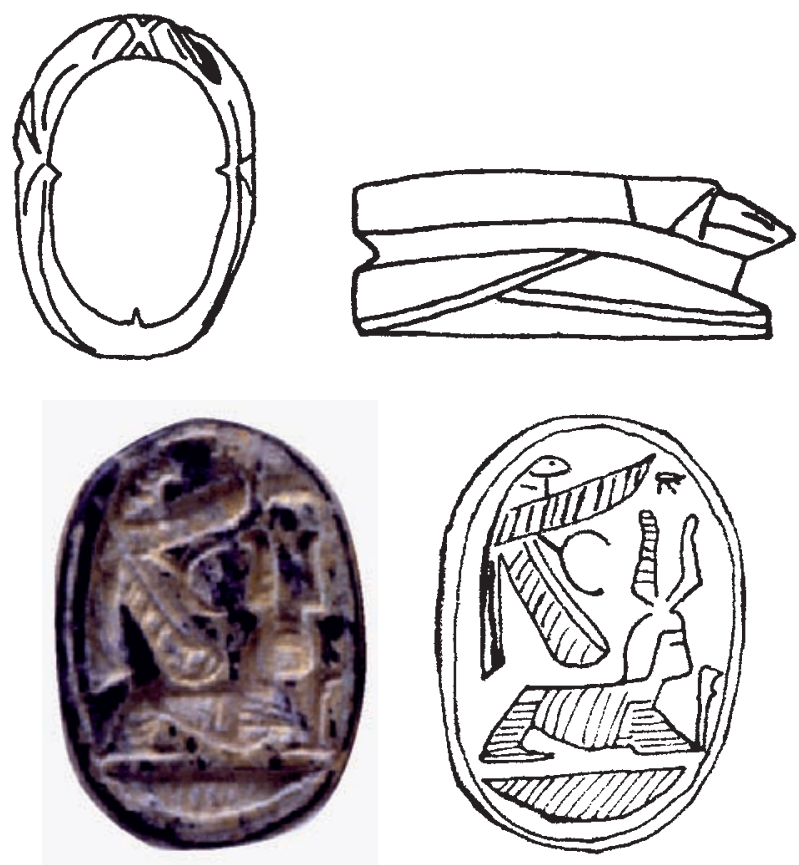

de Barcelona, el último al cribarse el sedimento señalado de la tumba en cuestión. De este modo, se considera que el conjunto de escaraboides y escarabeo corresponderían a una única sepultura (Padró, 1983, 93) y consecuentemente, a un único collar (Ferrer, 1991, 415; Mancebo y Ferrer, 1992, 316; Graells, 2010, 55). Todos los ejemplares recuperados en esta necrópolis están realizados en fayenza y se fechan en la primera mitad del siglo VI a.C.

Comentario: La tumba se fecha a mediados del siglo VI a.C. a partir de distintos materiales asociados: dos aríbalos globulares, una urna de orejetas, un broche de cinturón de tres garfios, un anillo y un brazalete de plata y una oil bottle de tipo fenicio centro-mediterráneo.

Lugar de conservación: Museu del Montsià (Amposta). № Inv.: 02155.

Conservación: Buen estado de conservación aunque la superficie ha perdido el acabado enlucido y barnizado.

Bibliografía: Padró, 1974, 71 y 78; 1983, 93-95, n 10.01: 1984, 105; Culican, 1972, 120; Maluquer, 1969; 2000, 147-148; Graells, 2010, 56, fig. 30.

Anverso: Se indica el protórax y no se representan los élitros. Las patas aparecen de manera esquemática.

Reverso: En el sello se observa una esfinge tumbada mirando a la derecha, con un Halcón con las alas abiertas y un Udjat encima, debajo el símbolo $n b$ y delante una pluma Maat. La escena está encuadrada por líneas.

Cronología: El contexto permite fechar la amortización de la pieza a mediados del siglo VI a.C. La cronología del sello de Tutmosis III propone una cronología de siglo XV a.C., pero muy posiblemente se trate de una reutilización del nombre en cronología posterior.

Iconografía: En su momento J. Padró consideró como piezas comparables los ejemplares el No. Inv. 36147, 36324 y 36236 del Museo del Cairo. Si bien este grupo de piezas egipcias se fechan en el Imperio Nuevo, particularmente bajo el reinado de Tutmosis III, recordaba el mismo investigador que el esquema dorsal de tipo II correspondía mayoritariamente a producciones hycsas y encontraba varios ejemplares con cronologías fiables en Cartago. Este grupo de piezas cartaginesas, fechadas entre el siglo VII y VI 
a.C., estaban realizadas en pasta, elementos que abogan por un renacimiento de lo arcaico en época saíta, dentro de la XXVI dinastía.

En Hispania se conocen otros paralelos con inscripciones alusivas a éste faraón: en la necrópolis de Medellín (Badajoz), con el basilíforo de Tutmosis III, pero fabricado durante el primer cuarto de siglo VI a.C., o sea, durante el reinado de Psamético II (595-589 a.C.). De Porto do Sabegueiro (Muge, Portugal) se conocen dos escarabeos, pero a diferencia del ejemplar de Medellín, parecen piezas realizadas durante el reinado de ese faraón, con lo que se propone una cronología de fabricación próxima a la mitad del siglo XV a.C. y una fecha para su llegada a la Península entre el siglo X y el VI a.C. (Horta, 1975, 175).

Comentario: Posiblemente se pueda atribuir a un escarabeo de Tutmosis III de producción saítica a imitación de aquellos (Padró, 1983, 93-95), de acuerdo con el resto de inscripciones sobre escarabeos a los que se asocia. De esta manera nos encontramos con una producción naucrática de finales del siglo VII o incios del siglo VI a.C.

\section{T-MM2. Mas de Mussols-2}
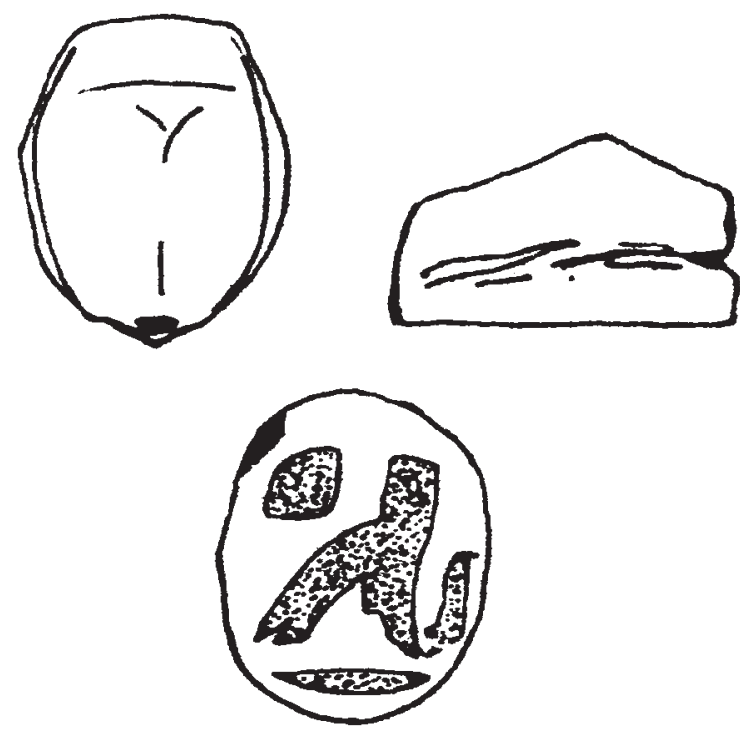

Material: Pasta dura de color verde con restos de barniz azul.

Dimensiones: Largo: $12 \mathrm{~mm}$; Ancho: $10 \mathrm{~mm}$; Alto: $7 \mathrm{~mm}$.

Perforación: Longitudinal.

Soporte: No se conserva.

Tipo: Indeterminado el esquema dorsal a causa del mal estado de conservación.

Grabado: realizado a molde.

Procedencia: Para el contexto y análisis, véase MM1.

Lugar de conservación: Museu del Montsià - Amposta. $\mathrm{N}^{\circ}$. Inv.: 02156

Conservación: Regular estado de conservación.

Bibliografía: Padró, 1974, 71 y ss.; 1983, 94-95, no 10.02; 1984, 106-107; Culican, 1972, 120; Maluquer, 1969; 2000, 147-148; Graells, 2010, 56, fig. 30.

Anverso: Indeterminado, las patas están indicadas.

Reverso: En el sello se lee el nombre de Psmtk, identificado como praenomen de Psamético II aunque podría proponerse que se tratara del nomen de Apries, como veremos, con un paralelo en la necrópolis de Can Canyís (CC3) y otro en la necrópolis del Jardín (Gamer-Wallert, 1977).
Cronología: Psamético I reinó del 663 al 609 a.C., dentro de la XXVI dinastía. A pesar de ello la perduración de las inscripciones con el mismo nombre puede proponer una cronología bajo el reinado de Psamético II (595/4-589/8 a.C.) o aún más relevante, una cronología bajo el reinado de Apris (589-570 a.C.), pues utiliza el praenomen de Psamético I (Vercoutter, 1945: 55; James, 2003, 251). Esta propuesta la refuerza la ausencia de inscripciones sobre escarabeos naucráticos del faraón Necao II (610-595 a.C.), sucesor de Psamético I y antecesor de Psamético II, hecho que apoya que el inicio de la producción de escarabeos naucráticos no es anterior a inicios del siglo VI a.C., según el modelo greco-colonial de von Bissing (1951), o entre el 570-565 a.C., según el modelo filo-fenicio de Hogarth (1898-1899; Hogarth, Lorimer y Edgar 1805, 107; discusión en James, 2003, 258).

Iconografía: Escarabeos con inscripciones de Psamético son conocidos en múltiples contextos como Náucratis, Carthago, Perachora (Gorton, 1996, 73, n 3) así como en Ibiza, Gibraltar o Can Canyís. De esta necrópolis se conoce un paralelo prácticamente idéntico en el n 3 (Padró, $1971,130)$ y destaca por su proximidad el ejemplar $n^{\circ}$ 37287 del Museo del Cairo. Según Gorton, esta representación corresponde a su grupo XXIII.A, frecuente en yacimientos griegos.

Comentario: La proximidad del lote de Mas de Mussols con el de Can Canyís es no sólo geográfica, sino también cronológica, hecho que lleva a comparar ambos lotes para precisar sus cronologías. Por ello, la proximidad entre el ejemplar que nos ocupa y el tercero del lote de Can Canyís permiten una buena comparación de contexto. En Can Canyís, su asociación al escarabeo CC12 con el nombre de Horus del faraón Psamético II permitió a J. Padró proponer que el ejemplar MM3 correspondiera a una producción de Psamético II utilizando el nombre de su predecesor, como cabe proponer para este ejemplar MM2 de Mas de Mussols.

\section{T-MM3. Mas de Mussols-3}
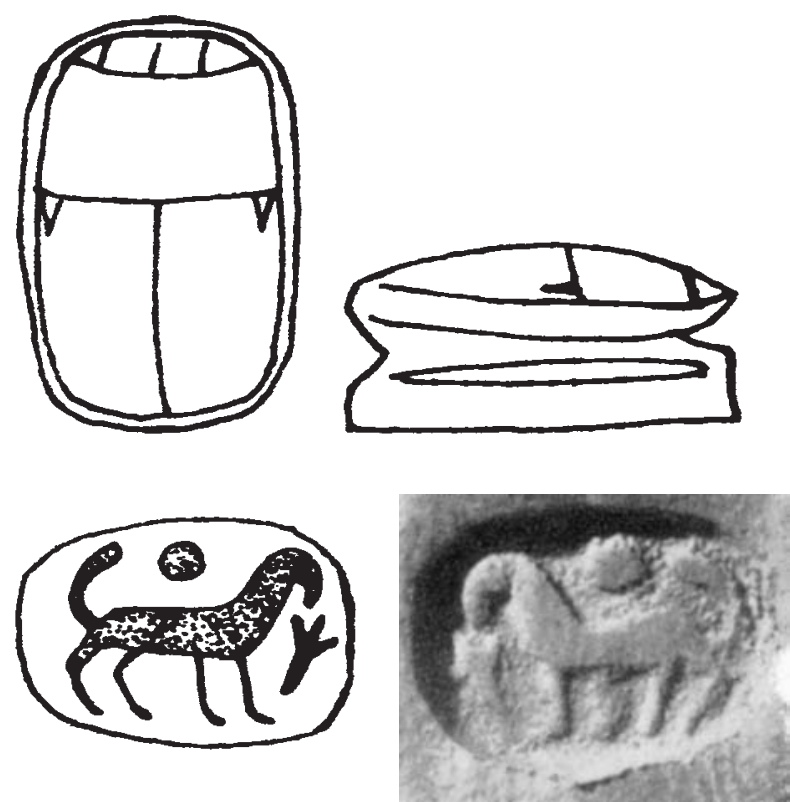

Material: Pasta dura de color verde con restos de barniz azul. 
Dimensiones: Largo: $13 \mathrm{~mm}$; Ancho: $9 \mathrm{~mm}$; Alto: $6 \mathrm{~mm}$.

Perforación: Longitudinal.

Soporte: No se conserva.

Tipo: El esquema dorsal corresponde al tipo VI de Vercoutter. Grabado: A molde.

Procedencia: Para el contexto y análisis véase MM1

Lugar de conservación: Museu del Montsià - Amposta. № Inv.: 10886.

Conservación: Buen estado de conservación.

Bibliografía: Padró, 1974, 71 y ss.; 1983, 95-96, n 10.03; 1984, 107-108; Gamer-Wallert, 1978, 202 y 263, nº A8, fig. 113, lám. 62C; Gorton, 1996, 94, nº 31; Culican, 1972, 120; Maluquer, 1969; 2000, 147-148; Graells, 2010, 56, fig. 30.

Anverso: En el sello aparece un león marchando a derecha con la cola levantada, con un sol encima y una flor de loto delante. Este último símbolo podría corresponder a otra interpretación aunque parece ésta la opción más probable.

Reverso: Presenta el detalle del protórax y los élitros marcados, con una $\mathrm{V}$ decorativa sobre cada ala.

Cronología: Se propone una cronología de primera mitad del siglo VI a.C., dada la ausencia de inscripciones anteriores a Psamético II en las producciones naucráticas (von Bissing, 1951, 65-66; James, 2003, 252; Gorton, 1996, 178).

Iconografía: Esta iconografía es ampliamente conocida en contextos cartagineses (Vercoutter, 1945, 163 y ss.), aunque la posición de los elementos o la ausencia de alguno de ellos dista ligera o sustancialmente del ejemplar aquí considerado. Aún así, el escarabeo de Mas de Mussols encuentra paralelos en Perachora (James, 1962, 502, fig. 36.517), otro en Náucratis (Gardner, 1888, lám. XVIII.8) y un último en la necrópolis de Can Canyís, CC5 (Padró, 1971, 131).

Comentario: Ha sido identificada como una producción naucrática a partir de la identificación allí de un escarabeo idéntico en cuanto a representación y dimensiones. J. Padró proponía incluso que corresponda a una producción de "técnica especial" realiza con el mismo molde (Padró, 1984, 108), hecho por otro lado nada descartable.

\section{T-MM4. Mas de Mussols-4}
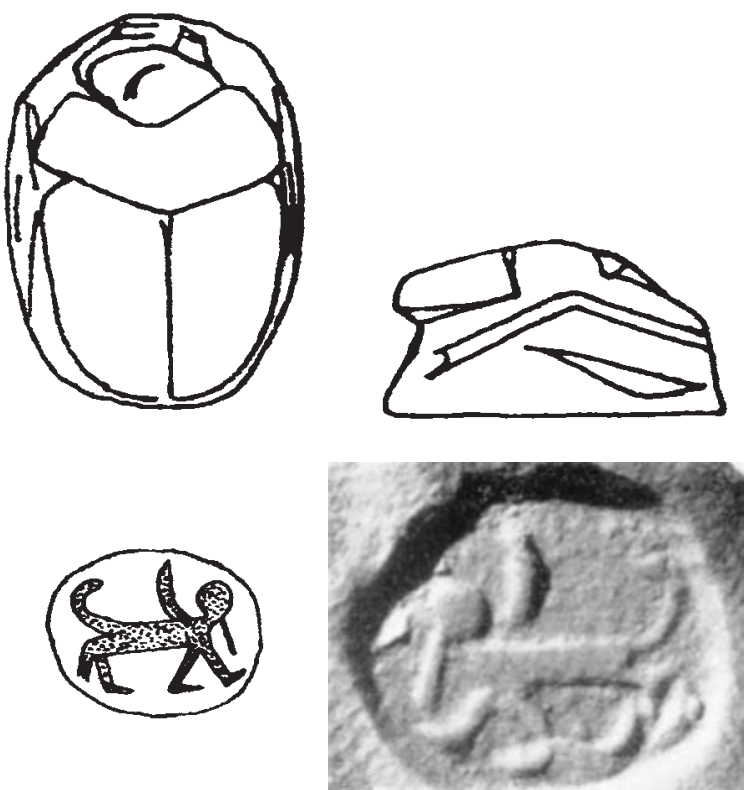

Material: Pasta dura de color verde.

Dimensiones: Largo: $13 \mathrm{~mm}$; Ancho: $10 \mathrm{~mm}$; Alto: $7 \mathrm{~mm}$.

Perforación: Longitudinal.

Soporte: No se conserva.

Tipo: V de Newberry (1906) y Vercoutter $(1945,73)$.

Grabado: Hecho a molde.

Procedencia: Para el contexto y análisis véase MM1.

Lugar de conservación: Museu del Montsià - Amposta. №. Inv.: 10887.

Conservación: Buen estado de conservación.

Bibliografía: Padró, 1974, 71; 1983, 96-97, no 10.04; 1984, 108; Gorton, 1996, 100, $\mathrm{n}^{\circ}$ 189; Culican, 1972, 120; Maluquer, 1969; 2000, 147-148; Graells, 2010, 56-57, fig. 30.

Anverso: Presenta el protórax redondeado y los élitros marcados.

Reverso: El sello presenta una esfinge alada en posición de caminar hacia la derecha con la cabeza humana barbada, que encuentra un paralelo en el Discoid Button-Seal CC10 de la necrópolis de Can Canyís. La cabeza está descubierta y la cola está levantada.

Cronología: Primera mitad del siglo VI a.C.

Iconografía: Las esfinges aladas en marcha son relativamente frecuentes. En particular, representaciones de esfinges aladas con o sin barba se documentan en Náucratis (Petrie, 1886, XXXVII.28 y 30), Cartago (Vercoutter, 1945, n' 281-286; Gorton, 1996, 75, nº 2), en la tumba 17 de la necrópolis de Douimes (Gorton, 1996, 58, $\mathrm{n}^{\circ} 17$ ), en Olbia (Gorton, 1996, 100, $\mathrm{n}^{\circ} 190$ ), en la tumba 341 de la necrópolis Fornacci de Capua (Melandri, 2010, fig. 7.4) y en el santuario complejo de Perachora (James, 1962, 502, fig. 36.532). Además, cabe incluir el ejemplar 10 de la necrópolis de Can Canyís, aunque su estado de conservación no permite asegurar la presencia de alas en su esfinge (Padró, 1971, 131; 1984, 108, n. 27).

Estas representaciones se identifican con los tipos XX.C y XXIII.B de Gorton, aunque ello no indique una cronología precisa, pues parece clara la producción naucrática, pero resulta significativa la primacía de la presencia del grupo XXIII.B en yacimientos griegos.

Comentario: Corresponde también a una producción naucràtica realizada con la llamada técnica "especial" de Vercoutter $(1945,162)$.

\section{T-MM5. Mas de Mussols-5}

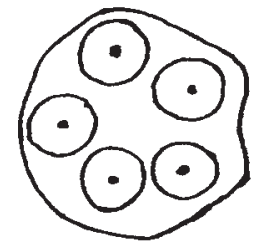

Material: Pasta roja con restos de barniz grisáceo.

Dimensiones: Diámetro: $13 \mathrm{~mm}$; Alto: $6 \mathrm{~mm}$.

Perforación: Diametral.

Soporte: No se conserva.

Tipo: Discoid Button-Seal.

Grabado: con tampón.

Procedencia: Para el contexto y su análisis, véase MM1

Lugar de conservación: Museu del Montsià - Amposta. № . Inv.: 02154.

Conservación: Frágil, la pasta de fayence se deshace. 
Bibliografía: Padró, 1974, 71; 1983, 97-98, n 10.05; 1984, 108-109; Gorton, 1996, 108, no 19; Culican, 1972, 120; Maluquer, 1969; 2000, 147-148; Graells, 2010, 57, fig. 30. Anverso: Liso

Reverso: Decoración de cinco círculos tangentes con un punto central.

Cronología: Primera mitad del siglo VI a.C.

Iconografía: La presencia de discos-escaraboide es habitual, incluso con la misma decoración, tanto en Náucratis (Petrie, 1886, lám. XXXVII.1-3; Gardner, 1888, lám. XVIII, 1-2) como en Cartago (Vercoutter, 1945, 172, lám. IX. 318). Similares al ejemplar de Mas de Mussols son varios ejemplares de Tarquinia, lamentablemente sin contexto. Según el catálogo de G. Hölbl, el ejemplar n 245 correspondería a un escarabeo en fayence con cinco impresiones (Hölbl, 1979, 51, $\left.\mathrm{n}^{\circ} 245\right)$, mientras que el ejemplar $n^{\circ} 264$ correspondería a un botón en ónice con nueve puntos (ibídem, 58, lám. 79.6). Por otro lado, puede considerarse dentro del mismo grupo 2 ejemplares de Conca (ibídem, lám. 96.5 y 97.3; Gorton, 1996, 108, n 20-21), Tarento (Hölbl, 1979, lám. 138.2, nº 1219; Gorton, 1996, 108, no 22), Perachora (James, 1962, 497, fig. 35, n 434; Gorton, 1996, 108, $\mathrm{n}^{\mathrm{o}}$ 23), 2 de Sunion (Gorton, 1996, 108, $\mathrm{n}^{\circ}$ 24-25), Lindos (ibídem, 108, n 26), Cyrene (ibídem, 108, $\mathrm{n}^{\circ} 27$ ) y 4 Náucratis (Petrie, 1886, lám. 37.2; Gardner, 1888, lám. 18.2; Gorton, 1996, 108, nº 28-31). Esta decoración mediante círculos con punto central realizada con tampón puede considerarse una evolución de una iconografía recurrente entre las producciones de tradición hyksa. La serie original presenta diferencias de composición entre sí tanto en lo que a número y disposición de los círculos se refiere como a la inclusión de elementos de distanciamiento y unión entre ellos, elementos que organizan los puntos. Por ejemplo, el ejemplar L.654 del BM procedente de la tumba 934 Tell el Farach (Gievon, 1985, 24), L.684 del BM procedente de la tumba 922 Tell el Farach (ibídem, 40), ejemplares L.1067 y L.1022 del BM procedente de Tell el-Ajjul (ibídem, 98), N.37213 de Newberry (Newberry, 1907, lám. XIII), Jericó N.299.1 y 299.1 (Kenyon, 1965). Esta característica organizativa desaparece en producciones como la del ejemplar de Mas de Mussols, demostrando así una ligera perduración cronológica.

En la Península Ibérica discos de forma similar aparecen, por ejemplo, en el conjunto de la necrópolis de Can Canyís, aunque no se conoce ningún otro ejemplar en Hispania con esta decoración.

Comentario: Es posible que se trate de una producción naucrática, aunque no sea seguro, pues, por ejemplo, A. F. Gorton no la considera como tal. En cualquier caso, ha sido clasificado dentro del tipo XXIX de Gorton (1996, 108), con una cronología y distribución idéntica a la del tipo XXVIII, dentro del arco propuesto para las producciones naucráticas.

\section{T-TOR1. Tortosa1}

Material: Pasta vidriada.

Dimensiones: Desconocidas.

Perforación: Longitudinal.

Soporte: No conservado.

Tipo: Indeterminado.

Grabado: A molde.

Procedencia: Desconocida. J. Padró considera que al haber pertenecido a la antigua colección Mestre i Noé, debería

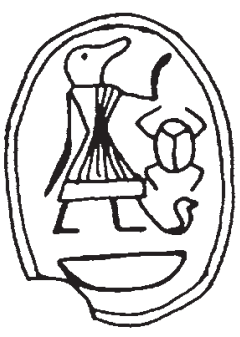

corresponder a un hallazgo local, quizás realizado en las necrópolis del entorno (Mas de Mussols, Mianes, etc.), por otro lado, se ha propuesto que pueda proceder del Barranc de Sant Antoni, junto a un ídolo fenicio, hallado entre 1910-1930.

Lugar de conservación: Desconocido. La colección Mestre i Noé ingresó en el Museo de Tortosa antes de la guerra civil, en la que desapareció.

Conservación: Buen estado de conservación a pesar de presentar el reverso una fractura en la parte superior izquierda. El estado de conservación del anverso es desconocido. Bibliografía: Jover, 1973, 114; Padró, 1971, 77, fig. 1.3; 1983, 98-99, n 10.51; Graells, 2010, fig. 30.

Anverso: Esquema dorsal indeterminado.

Reverso: Personaje de pie en movimiento a derecha, con cabeza de animal (posiblemente cocodrilo), mano izquierda alzada en ángulo recto y brazo derecho extendido al lado del cuerpo. Debajo del codo izquierdo, delante del personaje, representación esquemática del escarabajo, símbolo de la resurrección, orientado hacia arriba. Debajo del escarabajo serpiente. Debajo de la representación símbolo $n b$.

Cronología: J. Padró proponía una cronología a caballo entre el siglo VII y VI a.C. (Padró, 1983, 99) basada en la representación que ofrece.

Iconografía: El personaje puede identificarse con el dios Sobek, cuyo tipo de representación se considera dentro del gusto y tradición de las producciones hyksas, imitadas y reproducidas en gran número en época saita.

Padró presentaba varios paralelos procedentes de Egipto, particularmente $\mathrm{n}^{\circ} 36335$ y 36477 (Newberry, 1907, 85 y 120, Pl. VII) y no 36530 y 36738 (Newberry, 1907, 133 y 185, Pl. VII) del Museo del Cairo.

Comentario: La ausencia de datos y la diferencia iconográfica respecto al dossier considerado para el área "teórica" de hallazgo, pueden suponer algunas dudas para aceptar dicha pieza como de procedencia de la desembocadura del Ebro, pero el demostrado e importante comercio fenicio en el área justifican sobradamente su presencia, incluso en cronologías anteriores a los escarabeos de Mas de Mussols u otros contextos inmediatos.

\section{T-CC1. Can Canyís-1}

Material: Escarabeo de pasta de color verde-azulado, técnica "especial" de Vercoutter.

Dimensiones: Largo: $13 \mathrm{~mm}$; Ancho: $5 \mathrm{~mm}$.

Perforación: Longitudinal.

Soporte: No se conserva.

Tipo: Esquema dorsal de tipo VI de Newberry (1906, 70 s.) y Vercoutter (1945, 10 y 73).

Grabado: A molde.

Procedencia: La necrópolis de Can Canyís fue descubierta por trabajos agrícolas que destruyeron la mayoría de sus tumbas hacia 1960. Poco después S. Vilaseca realizó 

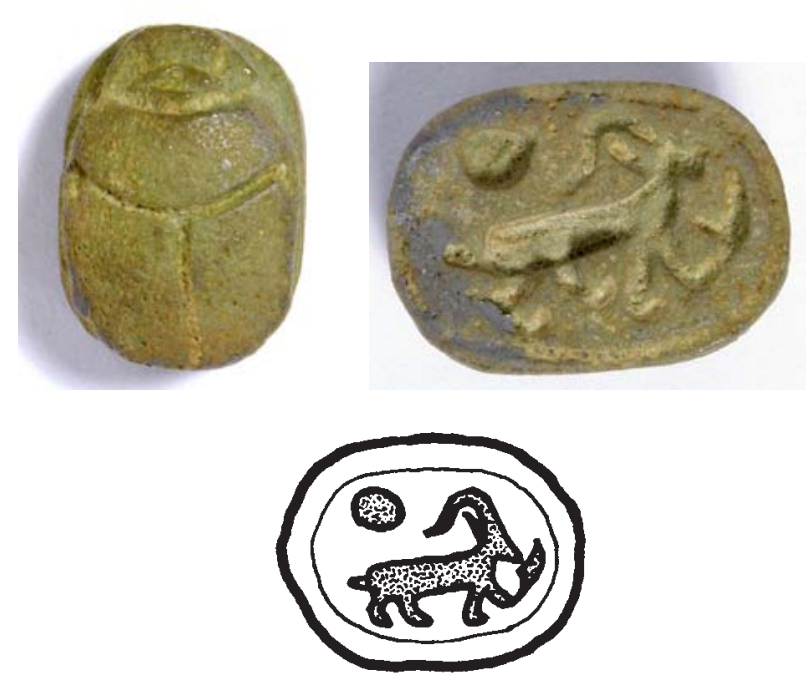

excavaciones, recuperó materiales y localizó una tumba intacta, con una documentación rigurosa de la localización de los materiales. La necrópolis fue fechada en un primer momento entre el 600-450 a.C., aunque estudios posteriores han concretado su fecha $c$. 575/550-475 a.C. (Bea, 1996). Esta nueva cronología es más acorde con los materiales, pues en dicha necrópolis no aparecen importaciones fenicias ni vasos a mano propios del paso del siglo VII al VI a.C. y, en cambio, las urnas y material metálico son propios del periodo Ibérico Antiguo del Nordeste Peninsular

En concreto, consta que los escarabeos y escaraboides recuperados en la necrópolis estaban proximos unos de otros, hecho que, junto a su semejanza tipológica, permite suponer que constituirían piezas de un mismo collar (Vilaseca et alii, 1963, 73; Padró, 1971, 129; Ferrer, 1991, 415; Mancebo y Ferrer, 1992, 316; Graells, 2010, 55). Un plano esquemático consultado en el Museu Salvador Vilaseca de Reus permite observar dónde fueron recuperados, pero sin mayores datos acerca de su contexto concreto.

Lugar de conservación: Casa Museu Àngel Guimerà Vendrell. MADV-7

Conservación: Regular.

Bibliografía: Vilaseca et alii, 1963, 54, lám. 29, nº 1; Padró, 1971, 130; 1983, 79-81, nº 09.01; Gamer-Wallert, 1978, 203, fig. 115, V.20; Gorton, 1996, 97, n 123; Culican, 1972, 120; Maluquer, 2000, 147-148; Graells, 2010, 57, fig. 30.

Anverso: El dorso presenta el protórax y los élitros separados por una única línea.

Reverso: En el sello, rodeado por una línea, representación de un antílope caminando a derecha, con pluma ante la pata adelantada y disco solar encima.

Cronología: Esta pieza corresponde al tipo XXVIII de Gorton (1996, 93), cuyos jeroglíficos de su variante B se fechan entre Psamético I y II y, aunque pueden aparecer otros nombres, raramente ayudan a la datación, esto es c. 670-570 a.C.

Paralelos e Iconografía: Según J. Padró, es de producción naucrática (Padró, 1971, 130). Este tipo ofrece varios paralelos, sin contexto, en los santuarios de Perachora (James, 1962, 501, fig. 36.489 y fig. 36. 495; Gorton, 1996, 97, $\mathrm{n}^{\mathrm{o}}$ 122), en Lindos (Gorton, 1996, 97, $\mathrm{n}^{\mathrm{o}} 121$ ), 3 de Náucratis (Gorton, 1996, 97, n 118-120; Gardner,
1888, lám. 18, nº 11-13), 2 de Conca (Hölbl, 1979, 165, no 646-647, lám. 95.6-7; Gorton, 1996, 97, no 125-126) y en la tumba 364 de de la necrópolis de San Montano en Ischia (Hölbl, 1979, 183, n 762, lám. 101.4; Gorton, 1996, 29, n $\mathrm{n}^{\mathrm{O}} 22$ ).

Comentario: Según A. F. Gorton (1996, tipo XXVIII.B), el grupo lo integrarían piezas con representaciones de animales en movimiento y en reposo dada su proximidad estilística.

\section{T-CC2. Can Canyís-2}
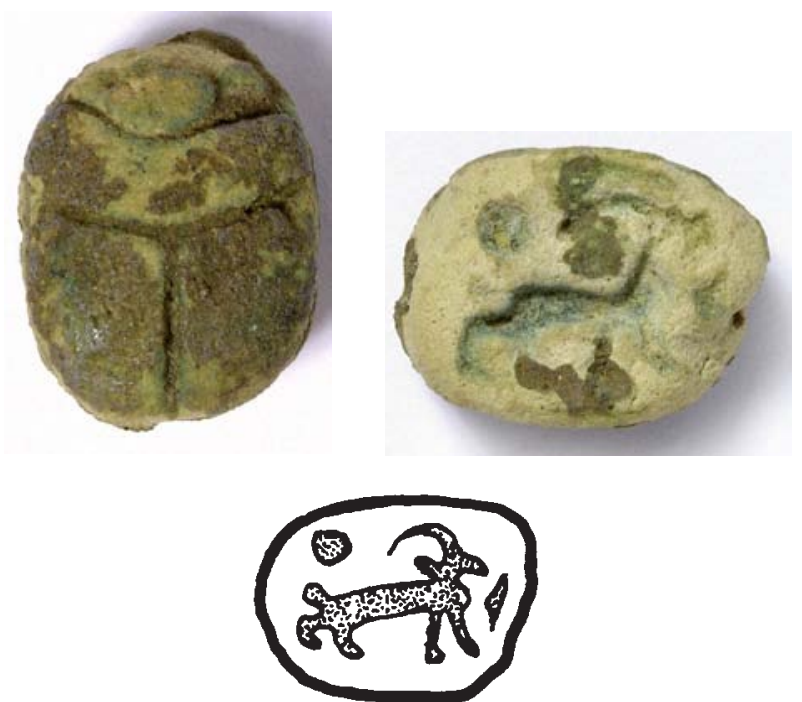

Material: Pasta de color verde-azulado, técnica "especial" de Vercoutter.

Dimensiones: Largo: $11 \mathrm{~mm}$; Ancho: $8 \mathrm{~mm}$; Alto: $5 \mathrm{~mm}$.

Perforación: Longitudinal.

Soporte: No se conserva.

Tipo: Esquema dorsal de tipo VI.

Grabado: A molde.

Procedencia: Conjunto Can Canyís, posiblemente de un único collar.

Comentario: Para un comentario del conjunto ver CC1.

Lugar de conservación: Casa Museu Àngel Guimerà - el Vendrell. MADV-8.

Conservación: Regular.

Bibliografía: Vilaseca et alii, 1963, 53, lám. 29, n 1; Padró, 1971, 130; 1983, 79-81, n 09.02; Gorton, 1996, 97, $\mathrm{n}^{\circ}$ 124; Gamer-Wallert, 1978, 203, fig. 115, V.21; Culican, 1972, 120; Maluquer, 2000, 147-148; Graells, 2010, 57, fig. 30.

Anverso: El dorso presenta el protórax y los élitros separados por una única línea.

Reverso: En el sello, rodeado por una línea, representación de un antílope caminando a derecha, con pluma en la pata adelantada y disco solar encima. Idéntica representación que el ejemplar anterior.

Paralelos y cronología: Vid. supra, CC1. Según J. Padró, es de producción naucrática (Padró, 1971, 130).

\section{T-CC3. Can Canyís-3}

Material: Pasta de color verde-azulado, técnica "especial" de Vercoutter.

Dimensiones: Largo: $12 \mathrm{~mm}$; Ancho: $7 \mathrm{~mm}$; Alto: $5 \mathrm{~mm}$.

Perforación: longitudinal.

Soporte: No se conserva. 


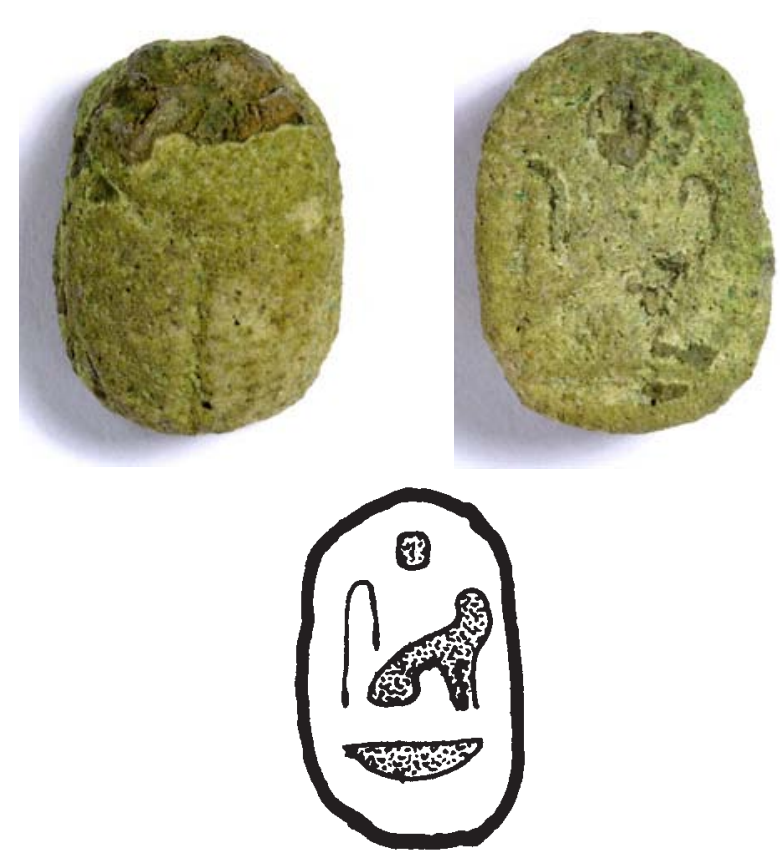

Tipo: Esquema dorsal de tipo VI.

Grabado: A molde.

Procedencia: Conjunto Can Canyís, posiblemente de un único collar

Comentario: Para un comentario del conjunto ver CC1.

Lugar de conservación: Casa Museu Àngel Guimerà Vendrell. MADV-9.

Conservación: Regular.

Bibliografía: Vilaseca et alii, 1963, 54, lám. 29, n ${ }^{\circ}$ 6; Padró, 1971, 130; 1983, 82, n 09.03; Culican, 1972, 120; Maluquer, 2000, 147-148; Graells, 2010, 57, fig. 30.

Anverso: El dorso presenta el protórax y los élitros separados por una única línea.

Reverso: En el sello: Psmtk (Psamético), con la $p$ en la parte superior, al centro la $s$ y el símbolo $m$, y debajo el símbolo $k$ (incompleto).

Cronología: Posiblemente corresponde a Psamético II, dada la incompleta ortografía del jeroglífico.

Iconografía: Encuentra paralelos en la colección del Museo del Cairo (Newberry, 1906, lám. XXXVIII.9) y en el ejemplar 2 del Mas de Mussols. Según J. Padró, es de producción naucrática (Padró, 1971, 130).

\section{T-CC4. Can Canyís-4}

Material: Pasta de color verde-azulado, técnica "especial" de Vercoutter.

Dimensiones: Largo: $10 \mathrm{~mm}$; Ancho: $8 \mathrm{~mm}$; Alto: $5 \mathrm{~mm}$.

Perforación: Longitudinal.

Soporte: No se conserva.

Tipo: Esquema dorsal de tipo VI.

Grabado: A molde.

Procedencia: Conjunto Can Canyís, posiblemente de un único collar.

Comentario: Para un comentario del conjunto ver CC1.

Lugar de conservación: Casa Museu Àngel Guimerà Vendrell. MADV-10.

Conservación: Regular.

Bibliografía: Vilaseca et alii, 1963, 53 y 73, lám. 29, nº 5; Padró, 1971, 130; 1983, 82-83, no 90.04; Gamer-Wallert, 1978, 202, fig. 111, Pl. 64a, nº 17; Gorton, 1996, 95, nº 60;

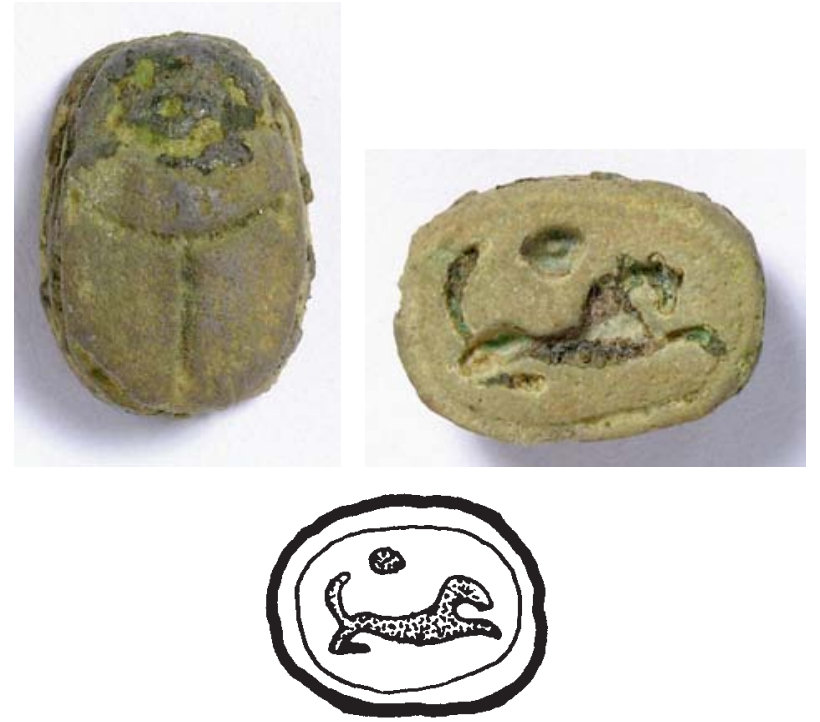

Culican, 1972, 120; Maluquer, 2000, 147-148; Graells, 2010, 57, fig. 30 .

Anverso: León tumbado mirando a derecha con disco solar encima. La representación está rodeada por una línea a modo de orla.

Reverso: El dorso presenta el protórax y los élitros separados por una única línea.

Cronología: El motivo es característico del reinado de Psamético I, pero se fecha en el reinado de Psamético II por su asociación con el resto de escarabeos de la necrópolis (Padró, 1983, 83) y por el tipo de inscripción, seguramente tardía (Padró, 1983, 110). Escarabeos de Psamético I en Hispania han aparecido en la necrópolis de Señora dos Mártires, en Alcácer do Sal (Gamer-Wallert, 1982; Gamer-Wallert y Cavaleiro-Paixâo, 1983), cuyos escarabeos se fechan entre el siglo VII e inicios del VI a.C., cronología confirmada por su asociación a enterramientos de tipo 4 (Arruda, 2002, 77). Escarabeos de Psamético II han aparecido en la tumba 9 del Cabezo de La Joya, Huelva (Gamer-Wallert, 1973; Padró, 1985) y en Gorham's Cave, Gibraltar (Culican, 1972; Padró, 1985).

Aunque la perduración de producciones de un reinado a otro puede ser considerada y es perfectamente factible datar este ejemplar en tiempos de Pasmético I, la pieza puede considerarse una perduración fechada con el resto del conjunto, que ofrece otras dos piezas con inscripciones similares (CC.8 y CC14).

Iconografía: Tiene un paralelo en la tumba 6 de la necrópolis de la Solivella. El tipo, con ligeras variantes en la que el león aparece en marcha hacia la izquierda y no tumbado, encuentra una serie importante de paralelos entre los materiales del complejo de santuarios de Perachora (Para los ejemplares idénticos: James, 1962, 503, fig. 36.538-539. Para las variantes con el león en marcha, James, 1962, 502-503, fig. 36.515-526 y fig. 36.529-536), Tarquinia (Hölbl, 1979, 51, n 246), Náucratis (Petrie, 1886, lám. XXXVII.42) o Carthago (Vercoutter, 1945, 162, n 269272).

Comentario: Según opinión de J. Padró, sería de producción naucrática (Padró, 1971, 130).

\section{T-CC5. Can Canyís-5}

Material: Pasta de color verde-azulado, técnica "especial" de Vercoutter. 


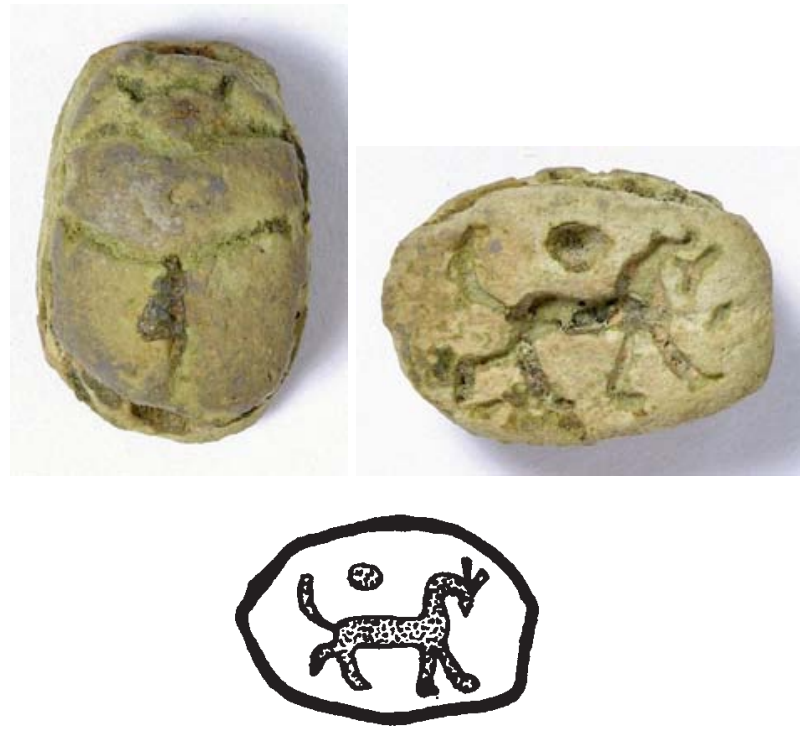

Dimensiones: Largo: $10 \mathrm{~mm}$; Ancho: $7 \mathrm{~mm}$; Alto: $5 \mathrm{~mm}$.

Perforación: Longitudinal.

Soporte: No se conserva.

Tipo: Esquema dorsal de tipo VI.

Grabado: A molde.

Procedencia: Conjunto Can Canyís, posiblemente de un único collar.

Comentario: Para un comentario del conjunto ver $\mathrm{CC} 1$.

Lugar de conservación: Casa Museu Àngel Guimerà Vendrell. MADV-11.

Conservación: Regular.

Bibliografía: Vilaseca et alii, 1963, 53 y 73, lám. 29, nº 4; Padró, 1971, 131; 1983, 83-84, nº 09.05, lám. 49; GamerWallert, 1978, lám. 64c, n V.19; Gorton, 1996, 94, n 30; Culican, 1972, 120; Maluquer, 2000, 147-148; Graells, 2010, 57, fig. 30.

Anverso: El dorso presenta el protórax y los élitros separados por una única línea.

Reverso: Cuadrúpedo con cuernos, posiblemente un ovicáprido, pasando a derecha con disco solar encima del cuerpo. J. Padró hizo notar que la representación de este animal era más frecuente que la de un león.

Cronología: La cronología del contexto corresponde al arco delimitado por el resto de ejemplares de la necrópolis de Can Canyís.

Iconografía: De segura producción naucrática. Encuentra un paralelo en el ejemplar 3 del Mas de Mussols. La semejanza entre el escarabeo de Can Canyís y el de Mas de Mussols puede fijar una cronología de fabricación de principios del siglo VI a.C. (Maluquer, 1984, 107).

\section{T-CC.6. Can Canyís-6}

Material: Pasta de color verde-azulado, técnica "especial" de Vercoutter.

Dimensiones: Largo: $13 \mathrm{~mm}$; Ancho: $7 \mathrm{~mm}$; Alto: $7 \mathrm{~mm}$.

Perforación: Longitudinal.

Soporte: No se conserva.

Tipo: Esquema dorsal de tipo VI.

Grabado: A molde.

Procedencia: Conjunto Can Canyís, posiblemente de un único collar.

Contexto: Véase CC1.

Lugar de conservación: Casa Museu Àngel Guimerà Vendrell. MADV-12.

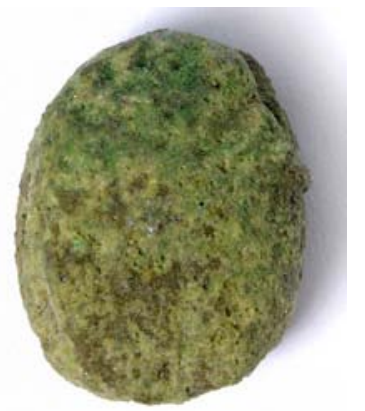

Conservación: Mala.

Bibliografía: Vilaseca et alii, 1963, lám. 29; Padró, 1971, 131; 1983: 84, lám. 49, 09.06; Culican, 1972, 120; Maluquer, 2000, 147-148; Graells, 2010, 57, fig. 30.

Anverso: El dorso presenta el protórax y los élitros separados por una única línea.

Reverso: Resulta imposible reproducir el grabado del sello.

Cronología: La cronología del contexto corresponde al arco delimitado por el resto de ejemplares de la necrópolis de Can Canyís.

Iconografía: Indeterminada.

Comentario: Según opinión de J. Padró, sería de producción naucrática (Padró, 1971, 130).

\section{T-CC7. Can Canyís-7}
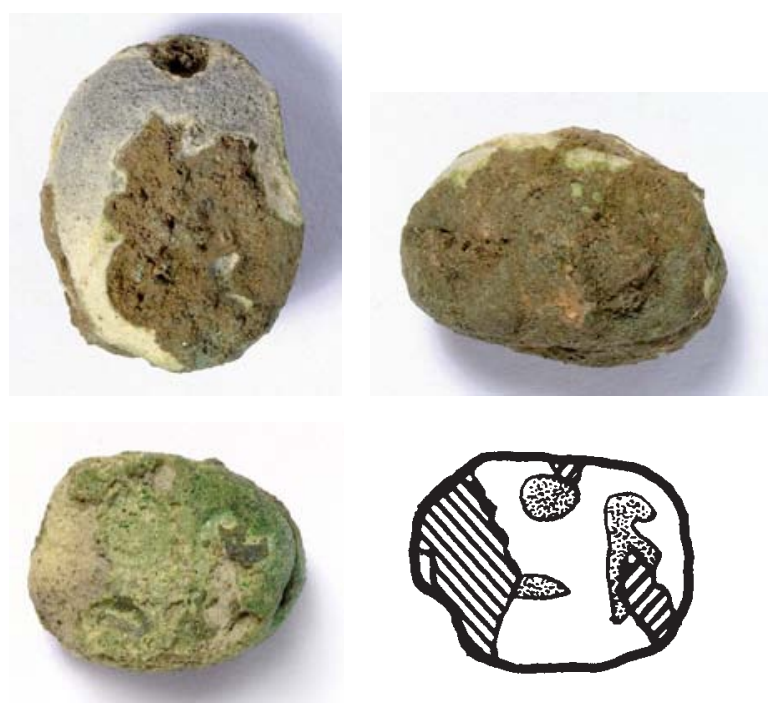

Material: Pasta de color verde-azulado, técnica "especial" de Vercoutter.

Dimensiones: Largo: $13 \mathrm{~mm}$; Ancho: $10 \mathrm{~mm}$; Alto: $6 \mathrm{~mm}$.

Perforación: Longitudinal.

Soporte: No se conserva.

Tipo: Esquema dorsal de tipo VI.

Grabado: A molde.

Procedencia: Conjunto Can Canyís, posiblemente de un único collar.

Comentario: Para un comentario del conjunto ver CC1.

Lugar de conservación: Casa Museu Àngel Guimerà Vendrell. MADV-13.

Conservación: Fragmentado e incompleto.

Bibliografía: Vilaseca et alii, 1963, lám. 29; Padró, 1971, 131, no 7; 1983, 85, lám. 49, nº 09.07; Gorton, 1996, 104; Culican, 1972, 120; Maluquer, 2000, 147-148; Graells, 2010, 57, fig. 30 . 
Anverso: El dorso presenta el protórax y los élitros separados por una única línea.

Reverso: A pesar del mal estado de conservación, en el sello parece leerse $N b-M$ ', ' $t-R$ ', que puede interpretarse como "Rey del Alto y Bajo Egipto" dentro de la tradición de Amen-hotep III (Padró, 1971, 131).

Cronología: En el sello se lee el nombre de Amenothep III (Padró, 1983, 85), con la inscripción jeroglífica neb-maat-Ra (Gorton, 1996, 104). Corresponde al tipo XXVIII de Gorton, en su variante B, atribuida a Psamético I y Pasmético II, considerada de producción naucrática.

Iconografía: Escarabeos con este nombre se encuentran en el ejemplar de Montlaurés F-MON4 (Padró, 1983, 03.04; Gorton, 1996, 104, no 70a), Cerdeña, posiblemente de Cagliari (Gorton, 1996, 104, $\mathrm{n}^{\circ}$ 70), Cartago (Vercoutter, 1945, n 308; Gorton, 1996, 104, n ${ }^{\circ} 68$ ) y en el del Cortijo de las Sombras (Padró, 1983, 25.01).

Comentario: Según opinión de J. Padró, sería de producción naucrática (Padró, 1971, 130).

\section{T-CC8. Can Canyís-8}
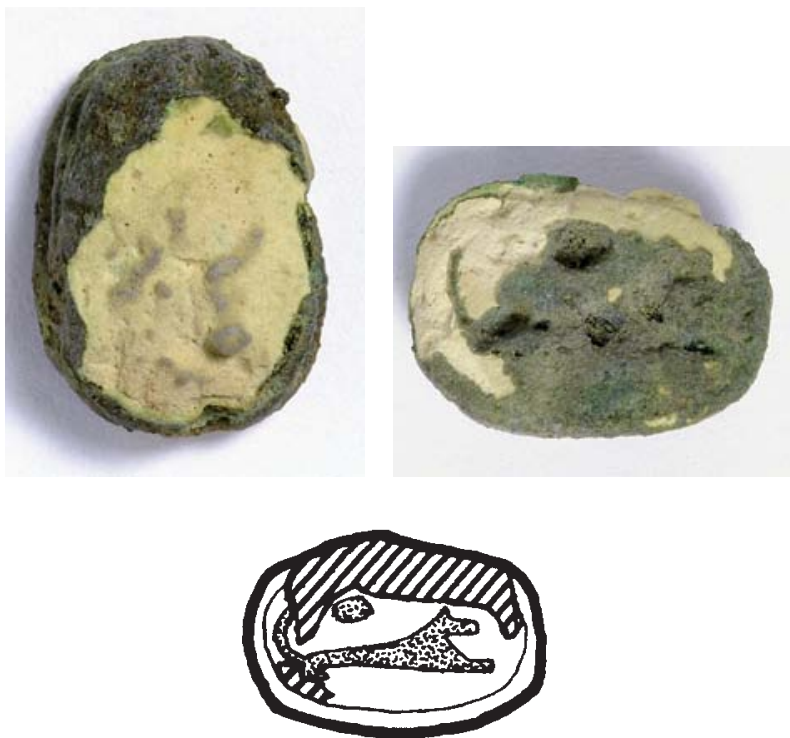

Material: Pasta de color verde-azulado, técnica "especial" de Vercoutter.

Dimensiones: Largo: $12 \mathrm{~mm}$; Ancho: $8 \mathrm{~mm}$; Alto: $6 \mathrm{~mm}$.

Perforación: Longitudinal.

Soporte: No se conserva.

Tipo: Esquema dorsal de tipo VI.

Grabado: A molde.

Procedencia: Conjunto Can Canyís, posiblemente de un único collar.

Comentario: Para un comentario del conjunto ver CC1.

Lugar de conservación: Casa Museu Àngel Guimerà Vendrell. MADV-14.

Conservación: Regular. En peor estado que el ejemplar CC4.

Bibliografía: Vilaseca et alii, 1963, 53 y 73, lám. 29, nº 3; Padró, 1971, 131; 1983, 86, nº 90.08; Gamer-Wallert, 1978, 202, fig. 112, Pl. 64a, no 18; Gorton, 1996, 95, nº 61; Culican, 1972, 120; Maluquer, 2000, 147-148; Graells, 2010, 57, fig. 30.

Anverso: El dorso presenta el protórax y los élitros separados por una única línea.
Reverso: León tumbado mirando a derecha, disco solar encima. La representación está rodeada por una línea.

Cronología: La cronología del contexto corresponde al arco delimitado por el resto de ejemplares de la necrópolis de Can Canyís.

Iconografía: Plantea el mismo problema interpretativo que el ejemplar CC4, pero este ejemplar ofrece paralelos en el tipo VIII de Gorton, particularmente en la tumba 18 de la necrópolis de Utica (Gorton, 1996, 25, fig. 4, n 11) y en 2 ejemplares de la necrópolis de la colina de Saint-Louis de Cartago (ibídem, 25, fig. 4, $\mathrm{n}^{\circ} 12$ ).

Comentario: Según J. Padró, es de producción naucrática (Padró, 1971, 130).

\section{T-CC9. Can Canyís-9}
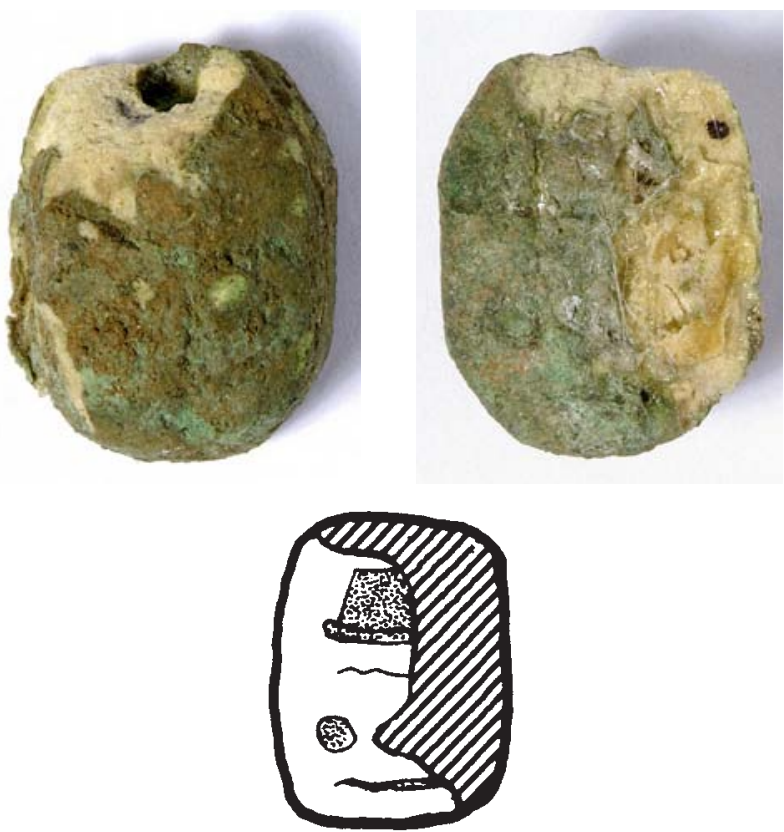

Material: Pasta de color verde-azulado, técnica "especial" de Vercoutter.

Dimensiones: Largo: $13 \mathrm{~mm}$; Ancho: $10 \mathrm{~mm}$; Alto: $7 \mathrm{~mm}$.

Perforación: Longitudinal.

Soporte: No se conserva.

Tipo: Esquema dorsal de tipo VI.

Grabado: A molde.

Procedencia: Conjunto Can Canyís, posiblemente de un único collar.

Comentario: Para un comentario del conjunto ver CC1.

Lugar de conservación: Casa Museu Àngel Guimerà Vendrell. MADV-15.

Conservación: Regular e incompleto.

Bibliografía: Vilaseca et alii, 1963, lám. 29; Padró, 1971, 131, nº 9; 1983, 86, lám. 49, nº 09.09; Gorton, 1996, 104, $\mathrm{n}^{\circ}$ 99; Culican, 1972, 120; Maluquer, 2000, 147-148; Graells, 2010, 57, fig. 30.

Anverso: El dorso presenta el protórax y los élitros separados por una única línea.

Reverso: Posiblemente Imn-r'nb (Padró, 1983, 86), transcrito como Amen-Ra (Gorton, 1996, 104, no 99) o "El señor es Amon-Re" (Padró, 1971, 131).

Cronología: Corresponde al tipo XXVIII de Gorton, en su variante $\mathrm{B}$, que se fecha entre Psamético I y II y se considera una producción naucrática. 
Iconografía: Paralelos del tipo se documentan en Náucratis (Londres Eg. 66486; Petrie, 1886, lám. 37, nº 90; Gorton, 1996, 104, $\mathrm{n}^{\circ}$ 97), Quíos (Gorton, 1996, 104, $\mathrm{n}^{\circ}$ 98), Tarento (18) (Hölbl, 1979, 225-226, nº 1113-1123, lám. 126; Gorton, 1996, 104, n $\left.\mathrm{n}^{\mathrm{1}} 100-117\right)$ y en la Península Ibérica también tiene paralelos en el Cortijo de las Sombras, Frigiliana, Málaga, fechable en el tránsito entre el siglo VII al VI a.C. (Padró, 1985), El Molar, San Fulgencio, Alicante, de mediados del siglo VI a.C. (Padró, 1983), Peña Negra, Crevillente, Alicante, con cuatro escarabeos con el trigrama de Amón, datados entre el siglo VII y el VI a.C.

\section{T-CC10. Can Canyís-10}
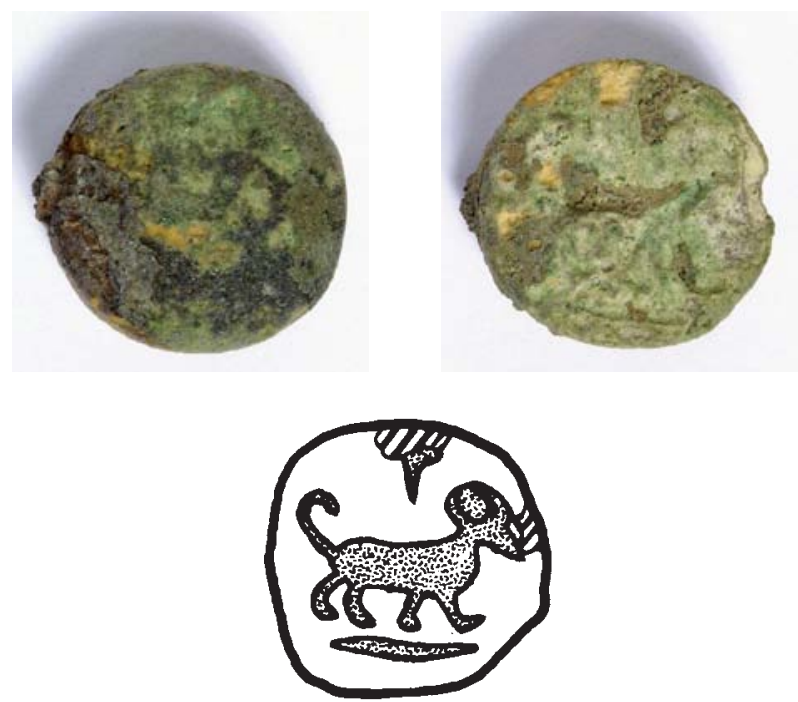

Material: Pasta de color verde-azulado, técnica "especial" de Vercoutter.

Dimensiones: Diámetro: $13 \mathrm{~mm}$; Alto: $7 \mathrm{~mm}$.

Perforación: Longitudinal.

Soporte: No se conserva.

Tipo: Discoid Button-Seal.

Grabado: A molde.

Procedencia: Conjunto Can Canyís, posiblemente de un único collar.

Comentario: Para un comentario del conjunto ver CC1.

Lugar de conservación: Casa Museu Àngel Guimerà Vendrell. MADV-16.

Conservación: Regular.

Bibliografía: Vilaseca et alii, 1963, 54, lám. 30, nº 1; Padró, 1971, 131, no 10; 1983, 87, lám. 49, no 09.10; GamerWallert, 1978, 203, fig. 117, lám. 63, n 23; Gorton, 1996, 97, no 135; Culican, 1972, 120; Maluquer, 2000, 147-148; Graells, 2010, 57, fig. 30.

Anverso: Liso.

Reverso: Esfinge caminando a derecha, con cabeza humana barbada con símbolo de la vida encima.

Cronología: Este ejemplar ha sido propuesto como tipo XXVIII de Gorton, en su serie A. Como ya se ha adelantado, la cronología del tipo se fecha entre Psamético I y Psamético II, aunque su posible producción naucrática obligue a una cronología ligeramente más reciente.

Iconografía: Encuentra paralelos en 4 piezas de Náucratis (Petrie, 1886, lám. 37, $\mathrm{n}^{\circ} 15$ y 17; Gardner, 1888, lám. $18, \mathrm{n}^{\circ} 10$ y 15; Gorton, 1996, 97, n 127-130), Camiros (Londres GR.61.4-25.21; Gorton, 1996, 97), 2 de
Perachora (James, 1962, 50, fig. 36, nº 495-496; Gorton, 1996, 97, 132-133), Cartago (Vercoutter, 1945, no 504; Gorton, 1996, 97, $\mathrm{n}^{\circ}$ 134), 1 del santuario (Hölbl, 1979, 172, nº 681, lám. 96.7; Gorton, 1996, 98, n 136) y 3 de la necrópolis de Conca (Hölbl, 1979, 169-170, n 670-672, lám. 96.8-10; Gorton, 1996, 98, nº 137-139).

Comentario: Corresponde a un Discoid Button-Seal de producción naucrática.

\section{T-CC11. Can Canyís-11}
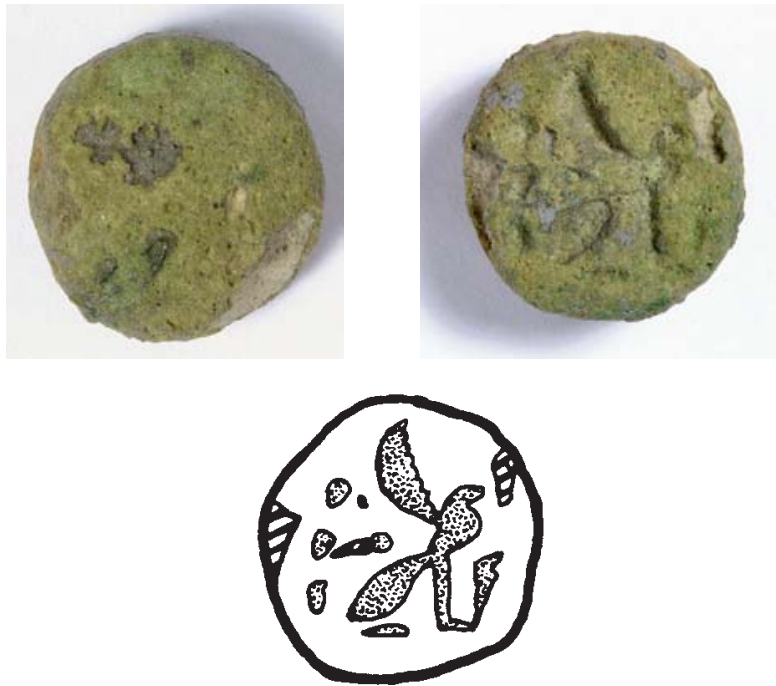

Material: Pasta de color verde-azulado, técnica "especial" de Vercoutter.

Dimensiones: Diámetro: $12 \mathrm{~mm}$; Alto: $6 \mathrm{~mm}$.

Perforación: Longitudinal.

Soporte: No se conserva.

Tipo: Discoid Button-Seal.

Grabado: A molde.

Procedencia: Conjunto Can Canyís, posiblemente de un único collar.

Comentario: Para un comentario del conjunto ver CC1.

Lugar de conservación: Casa Museu Àngel Guimerà Vendrell. MADV-17.

Conservación: Regular.

Bibliografía: Vilaseca et alii, 54, lám. 30, nº 1; Padró, 1971, 131-132, no 11; 1983, 87, lám. 49, nº 09.11; GamerWallert, 1978, 201-202, fig. 110, lám. 63; Gorton, 1996, $100, \mathrm{n}^{\circ}$ 187; Culican, 1972, 120; Maluquer, 2000, 147148; Graells, 2010, 57, fig. 30.

Anverso: Liso.

Reverso: En el sello ofrece una esfinge alada sentada a derecha, entre las patas Uraeus, detrás tres pequeños símbolos verticales ilegibles. J. Padró propuso que pudiera tratarse del nombre de algún faraón, aunque sin ejemplos (Padró, 1971, 131)

Cronología: La cronología de la pieza ofrece dudas. Sus paralelos con decoración compleja procedentes de contextos fenicios ofrecen una cronología ligeramente más alta que las producciones naucráticas, a pesar de que el soporte de la pieza y el estilo obligan a considerar más factible que sea de producción naucrática. Por tanto, su cronología debe corresponder a las producciones naucráticas, fechadas en la primera mitad del siglo VI a.C.

Iconografía: Representaciones similares a esta se conocen en la necrópolis de Tharros (Gorton, 1996, 44, fig. 7, nº 
21) y en la necrópolis de la Colina de Saint-Louis de Carthago (Vercoutter, 1945, $\mathrm{n}^{\circ}$ 133; Gorton, 1996, 44, fig. $\left.7, \mathrm{n}^{\circ} 5\right)$, hecho que permitió a Gorton plantear el tipo como propio de contextos fenicios. En cualquier caso, la pieza de Can Canyís aparece como pieza de tipo XXVIII de Gorton, con paralelos en Náucratis y Perachora (Gorton, $\left.1996,100, \mathrm{n}^{\circ} 184-186\right)$, aunque los paralelos presentados son sustancialmente más sencillos que el ejemplar de Can Canyís.

Comentario: Corresponde también a una producción naucràtica realizada con la llamada técnica "especial" de Vercoutter (Padró, 1971, 130).

\section{T-CC12. Can Canyís-12}

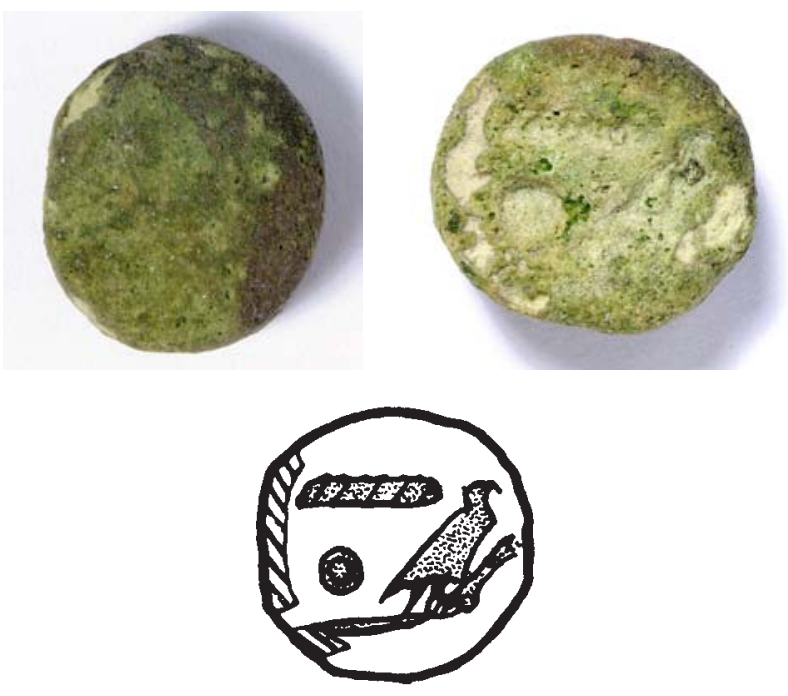

Material: Pasta de color verde-azulado, técnica "especial" de Vercoutter.

Dimensiones: Diámetro: $12 \mathrm{~mm}$; Alto: $5 \mathrm{~mm}$.

Perforación: Longitudinal.

Soporte: No se conserva.

Tipo: Discoid Button-Seal.

Grabado: Hecho a molde.

Procedencia: Conjunto de Can Canyís, posiblemente de un único collar.

Comentario: Para un comentario del conjunto ver CC1.

Lugar de conservación: Casa Museu Àngel Guimerà Vendrell. MADV-18.

Conservación: Regular.

Bibliografía: Vilaseca et alii, 1963, 54, lám. 31, n² 2; Padró, 1971, 132, no 12; 1983, 88-89, nº 09.12, lám. 49; GamerWallert, 1978, 201, fig. 201, lám. 63 a-b; Gorton, 1996, 103, nº 61; Culican, 1972, 120; Maluquer, 2000, 147-148; Graells, 2010, 57, fig. 30.

Anverso: Liso.

Reverso: Sello con el nombre de Horus de Psamético II, expresado mediante la contracción del nombre men-ib-Ra en la forma men-Ra (Gorton, 1996, 102) o Hr-mnh-[ib] - Hr-mn-R'(Padró, 1971, 132).

Cronología: Corresponde al tipo XXVIII de Gorton, variante B, fechada entre Psamético I y Psamético II, que se considera producción naucrática, aunque este escarabeo precisa el nombre de Psamético II (595-589 a.C.).

Iconografía: Encuentra paralelos en la colección del Museo del Cairo (Newberry, 1906, lám. XLI.22), Náucratis (Petrie, 1886, 37, nº 47-48; Gardner, 1888, lám. 18, nº 22;
Gorton, 1996, 103, n 58-60) y en la tumba 9 de la necrópolis de La Joya (Gamer-Wallert, 1973; Garrido, 1971).

Comentario: El nombre escrito en el jeroglífico aparece en escarabeos procedentes de Náucratis, Perachora, Cartago, Tarento y Tell Sukas (Gorton, 1996, 102-103), que repiten la distribución habitual de los paralelos de los escarabeos de Can Canyís y añaden nuevos puntos en el Sur de Italia y el Próximo Oriente.

\section{T-CC13. Can Canyís-13}

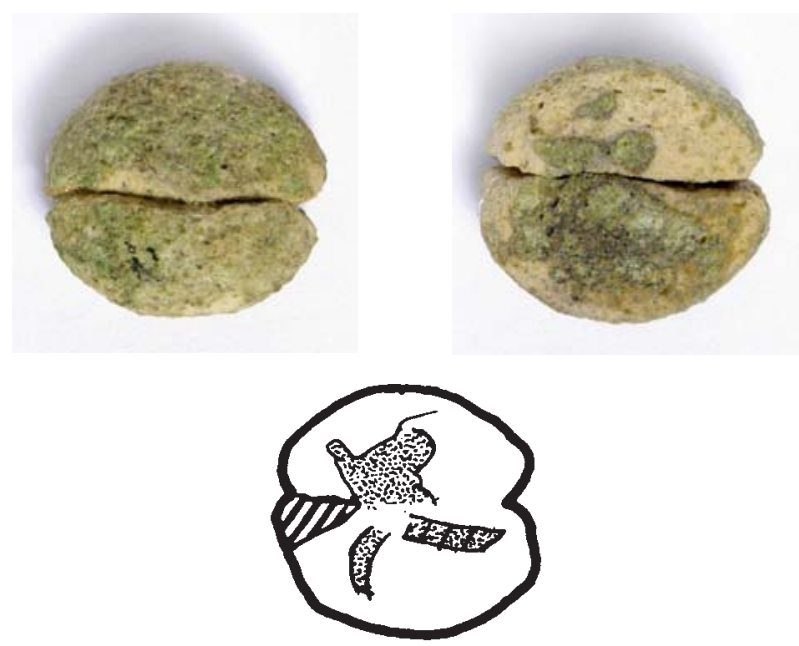

Material: Pasta de color verde-azulado, técnica "especial" de Vercoutter.

Dimensiones: Diámetro: $11 \mathrm{~mm}$; Alto: $5 \mathrm{~mm}$.

Perforación: Longitudinal.

Soporte: No se conserva.

Tipo: Discoid Button-Seal.

Grabado: A molde.

Procedencia: Conjunto Can Canyís, posiblemente de un único collar.

Comentario: Para un comentario del conjunto ver CC1.

Lugar de conservación: Casa Museu Àngel Guimerà Vendrell. MADV-19.

Conservación: Ilegible.

Bibliografía: Vilaseca et alii, 1963; Padró, 1971, 132, n 13; 1983, 89 s., lám. 49, nº 09.13; Culican, 1972, 120; Maluquer, 2000, 147-148; Graells, 2010, 57, fig. 30.

Anverso: Liso.

Reverso: Ilegible por su mal estado de conservación, pues sólo se observan trazos del grabado original.

Cronología: Corresponde al arco delimitado por el resto de ejemplares de la necrópolis de Can Canyís.

Iconografía: Indeterminada.

Comentario: Según opinión de J. Padró, es de producción naucrática (Padró, 1971, 130).

\section{T-CC14. Can Canyís-14}

Material: Pasta de color verde-azulado, técnica "especial" de Vercoutter.

Dimensiones: Diámetro: $12 \mathrm{~mm}$; Alto: $6 \mathrm{~mm}$.

Perforación: Longitudinal.

Soporte: No se conserva.

Tipo: Discoid Button-Seal.

Grabado: A molde.

Procedencia: Conjunto Can Canyís, posiblemente de un único collar.

Comentario: Para un comentario del conjunto ver CC1. 

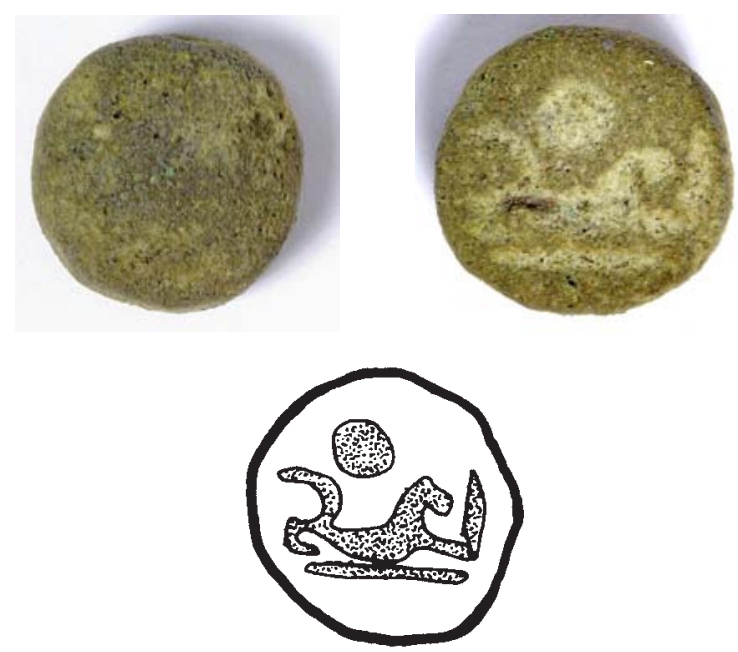

Lugar de conservación: Casa Museu Àngel Guimerà Vendrell. MADV-20.

Conservación: Regular.

Bibliografía: Vilaseca et alii, 1963, 54 y 73, lám. 30, nº 2; Padró, 1983, 90, nº 09.14; Gamer-Wallert, 1978, 202, fig. 114, lám. 63e-f, nº 22; Gorton, 1996, 95, nº 72a; Culican, 1972, 120; Maluquer, 2000, 147-148; Graells, 2010, 58, fig. 30.

Anverso: Liso.

Reverso: Sello con un león tumbado a derecha, con pluma maat entre las patas delanteras; encima disco solar.

Cronología: La cronología corresponde al arco delimitado por el resto de ejemplares de la necrópolis de Can Canyís. Iconografía: Similar a los ejemplares CC.4, CC.8 y de la t.6 de la necrópolis de la Solivella. Además, puede considerarse una representación próxima al ejemplar de la tumba 13 de Frigiliana, aunque con importantes diferencias, principalmente en la composición de la escena, ya que el sello aparece organizado con otros motivos (GamerWallert, 1975, 68-69).

Comentario: Según opinión de J. Padró, sería de producción naucrática (Padró, 1971, 130).

\section{T-CC15. Can Canyís-15}
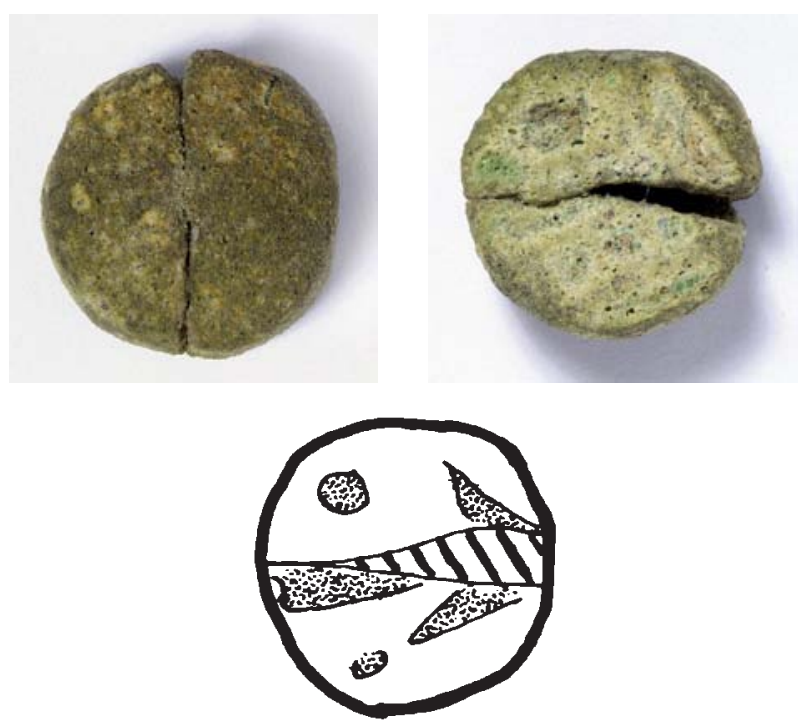

Material: Pasta de color verde-azulado, técnica "especial" de Vercoutter.

Dimensiones: Diámetro: $11 \mathrm{~mm}$; Alto: $6 \mathrm{~mm}$.

Perforación: Longitudinal.

Soporte: No se conserva.

Tipo: Discoid Button-Seal.

Grabado: A molde.

Procedencia: Conjunto Can Canyís, posiblemente de un único collar.

Comentario: Para un comentario del conjunto ver CC1.

Lugar de conservación: Casa Museu Àngel Guimerà Vendrell. MADV-21.

Conservación: Roto en dos partes, prácticamente ilegible.

Bibliografía: Vilaseca et alii, 1963; Padró, 1971, 132, n ${ }^{\circ}$ 15; 1983, 90-91, no 09.15; Culican, 1972, 120; Maluquer, 2000, 147-148; Graells, 2010, 58, fig. 30.

Anverso: Liso.

Reverso: Muy fragmentado y difícil de reconstruir. Conserva restos del grabado original, pero es imposible identificar el motivo que ofrece.

Cronología: Corresponde al arco delimitado por el resto de ejemplares de la necrópolis de Can Canyís.

Iconografía: Indeterminada.

Comentario: Según opinión de J. Padró, es de producción naucrática (Padró, 1971, 130).

\section{T-CC16. Can Canyís-16}

Material: Pasta de color verde-azulado, técnica "especial" de Vercoutter.

Dimensiones: Sin datos.

Perforación: Longitudinal.

Soporte: No se conserva.

Tipo: Escaraboide.

Grabado: Indeterminado

Procedencia: Conjunto Can Canyís, posiblemente de un único collar.

Comentario: Para un comentario del conjunto ver CC1.

Lugar de conservación: Casa Museu Àngel Guimerà Vendrell.

Conservación: Fragmentado.

Bibliografía: Padró, 1971, 132.

Anverso: Indeterminado.

Reverso: Indeterminado.

Cronología: Su cronología corresponde al resto de ejemplares de la necrópolis de Can Canyís.

Comentario: Según opinión de J. Padró, sería de producción naucrática (Padró, 1971, 130).

\section{T-CC17. Can Canyís-17}

Material: Pasta de color verde-azulado, técnica "especial" de Vercoutter.

Dimensiones: Sin datos.

Perforación: Longitudinal.

Soporte: No se conserva.

Tipo: Escaraboide.

Grabado: Indeterminado

Procedencia: Conjunto Can Canyís, posiblemente de un único collar.

Comentario: Para un comentario del conjunto ver CC1.

Lugar de conservación: Casa Museu Àngel Guimerà Vendrell.

Conservación: Fragmentado.

Bibliografía: Padró, 1971, 132.

Anverso: Indeterminado. 
Reverso: Indeterminado.

Cronología: La cronología corresponde al resto de ejemplares de la necrópolis de Can Canyís.

Comentario: Según opinión de J. Padró, es de producción naucrática (Padró, 1971, 130).

\section{T-CC18. Can Canyís-18}

Material: Pasta de color verde-azulado, técnica "especial" de Vercoutter.

Dimensiones: Sin datos.

Perforación: Longitudinal.

Soporte: No se conserva.

Tipo: Escaraboide.

Grabado: Indeterminado.

Procedencia: Conjunto Can Canyís, posiblemente de un único collar.

Comentario: Para un comentario del conjunto ver CC1.

Lugar de conservación: Casa Museu Àngel Guimerà Vendrell.

Conservación: Fragmentado.

Bibliografía: Padró, 1971, 132.

Anverso: Indeterminado.

Reverso: Indeterminado.

Cronología: Corresponde al resto de ejemplares de la necrópolis de Can Canyís.

Comentario: Según opinión de J. Padró, sería de producción naucrática (Padró, 1971, 130).

\section{T-LP1. La Pedrera-1, Collar de Tarragona-1}

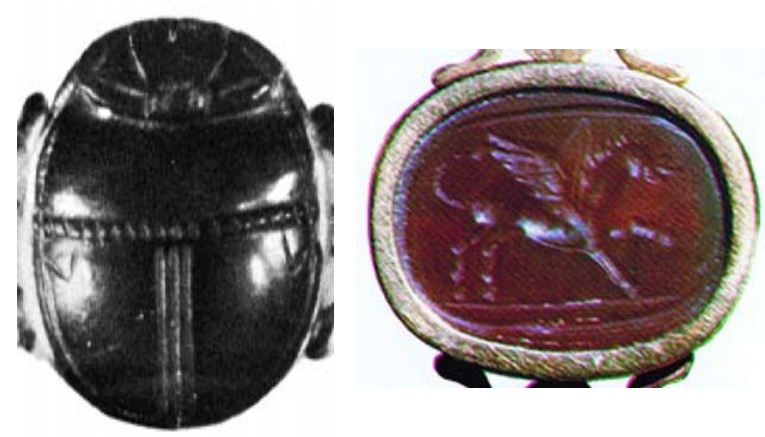

Material: Cornalina translúcida.

Dimensiones: Largo: $14 \mathrm{~mm}$; Ancho: $11 \mathrm{~mm}$.

Perforación: Longitudinal, pero no visible.

Soporte: No se conserva, aunque en la actualidad está engarzado en un sobrio aro de oro del que surgen dos apéndices o anillas articuladas que se unen a la cadena de oro, junto a otras 9 piedras grabadas.

Tipo: Escarabeo con decoración y acabado que se distancian de las tipologías egiptizantes.

Grabado: De buena calidad, profundo y preciso, aunque las patas no se observan.

Procedencia: Como ocurre con los dos ejemplares siguientes, la procedencia es indeterminada, aunque se supone que fue recuperado en las excavaciones y hallazgos del entorno tarraconense a lo largo del siglo XIX, en especial a fines del mismo, entre los que se cita el área de la Pedrera del Port o cantera del Puerto de Tarragona, donde aparecieron restos del siglo II d.C., por lo que se ha considerado como muestra de la influencia orientalista en el arte del Imperio Romano de ese siglo. Sin embargo, como hallazgo local, parece más lógico considerarlo como pro- cedente de un yacimiento destruido de época orientalizante, probablemente funerario, localizado en los alrededores de Tarragona.

Lugar de conservación: Museu Arqueològic Nacional de Tarragona, No. Inv.: 6971.

Conservación: Se conserva en buen estado de conservación con el acabado pulimentado.

Bibliografía: Rincomà, 1982, 33, n 5; Rodà, 2010, 42, fig. 13a-b; Graells, 2011, 170, fig. 37.5.

Anverso: La estructura del dorso ofrece una decoración y acabado que se distancian de las tipologías egiptizantes.

Reverso: Representa un Pegaso que vuela hacia la derecha.

Paralelos e iconografía: La representación encuentra paralelos en ejemplares romanos de Boardman (1970, 465, 512, 616, 622 y 958), y de la colección del Museo de Aquileia (Sena-Chiesa, 1966, no 1205, 1208 y 1209), así como en varios ejemplares recogidos por A. Furtwängler (1900, lám. IX.58, XI.27 y 41, XII.4 y 50-51, XXXI.7 y LXI.40), G.M. Richter (1956, nº I.368 y II.248) y M. L. Vollenweider (1979, lám. 12.6), paralelos que ofrecen representaciones de grifos próximas a las de este ejemplar tarraconense.

Cronología: La cronología propuesta para esta pieza varía entre los siglos II y I a.C.

Comentario: El collar perteneció a la Sra. María Fernández y fue donado al Museo Arqueológico de Tarragona el 1 de diciembre de 1913 por su heredero, el Sr. E. Minguell. La combinación de entalles en el mismo collar aproxima ésta colección a colecciones internacionales. Destaca el buen estado y diversidad de las piezas representadas y la presencia de dos entalles con inscripciones griegas (HKTANA y $\varsigma \kappa \lambda v v \kappa o \varsigma)$, que plantean dudas sobre la procedencia tarraconense del conjunto.

\section{T-LP2. La Pedrera-2, Collar de Tarragona 2}
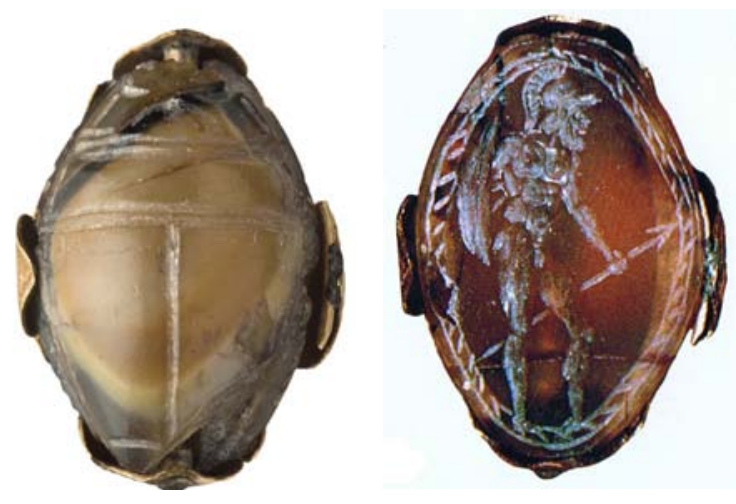

Material: Sardónice translúcida, que recientemente I. Rodà ha identificado como una calcedonia sarda.

Dimensiones: Largo: 21 mm; Ancho: 14 mm; Altura: 10 $\mathrm{mm}$.

Perforación: Longitudinal.

Soporte: Engarzado por cuatro puntos en oro formando parte de un collar de finales del siglo XIX.

Tipo: Romano.

Grabado: El grabado es de calidad y se conserva en buen estado. El grabado es una incisión irregular en la que se combina el grabado profundo de la representación humana mientras que el óvalo que rodea la figura presenta una ligera incisión con trazos angulosos que contrastan con el detalle de la figura. 
Procedencia: Igual que el ejemplar precedente y siguiente, la procedencia es indeterminada aunque se acepta como recuperado en las excavaciones y hallazgos del entorno tarraconense a lo largo del siglo XIX, particularmente en su momento final.

Comentario: Formaba parte de un collar de oro junto a otra nueve piezas entalladas. Posiblemente el collar sea de producción local, dada la simplicidad y distintos aspectos decorativos que lo distancian de las producciones europeas del momento (particularmente romanas y parisinas).

Lugar de conservación: Museu Arqueològic Nacional de Tarragona, $\mathrm{N}^{\mathrm{o}}$. Inv.: 6971 (Fotos 13722 y 13723 del MNAT).

Conservación: Excelente.

Bibliografía: Rincomà, 1982, 37, nº 8; Rodà, 2010, 43, fig. 16a-b; Graells, 2011, 170, fig. 37.7.

Anverso: El reverso presenta un grabado ligero, suave e irregular. Las líneas que esquemáticamente difinen las características del cuerpo distan mucho de las que observamos sobre producciones fenicias o etruscas, pues no son completamente rectas. Este trabajo dorsal sorprende en comparación con el ventral, mucho más preciso. El clípeo aparece insinuado por debajo del protórax decorado con una línea curva. El tórax, liso y encajado entre dos parejas de líneas paralelas. Los élitros, separados por una línea gruesa, también son lisos y ocupan no ha podido ser analizado. Cabe señalar la fractura del cuarto inferior derecho, que falta en la parte dorsal y no afecta a la ventral.

Reverso: Representación de guerrero heroizado con escudo, casco y lanza. El cuerpo, musculosos, está desnudo. La faz presenta barba. Esta representación idealizada del héroe bebe de la tradición helenística, de la que puede proponerse el prototipo. El guerrero, en pie, posa hacia la derecha dentro de un óvalo formado por dos líneas incisas con pequeñas líneas diagonales que rellenan el espacio intermedio a modo de cuerda o sogueado, tal y como se observa en ejemplares etruscos y helenísticos.

Cronología: La cronología del tipo se fecha en el siglo I a.C., a pesar de que Rincomà propuso una cronología de "influencia etrusca" y lo fechaba en el siglo II d.C. (Rincomà, 1982, 37, con la que no coincidimos).

Iconografía: La iconografía reproduce un motivo arcaico a pesar de que su factura parece ser de época tardo-republicana o incluso imperial. Por un lado el detalle del cuerpo puede compararse con ejemplares tardo-helenísticos, pero los trazos bruscos de las incisiones y la falta de plasticidad de la musculatura y, especialmente, del óvalo, indican una cronología romana, próxima ya a las producciones seriadas que colmaron el mercado del siglo I d.C.

Encuentra paralelos en los ejemplares 4-8 de la colección Ionides (Boardman, 1968) y en las recopilaciones de A. Furtwängler (1900, lám. X.4, XX.3, XXIII.6 y LXIV.40) y H.B. Walters (1926, lám. 16.1056).

Comentario: El estudio de M. Henig (1970), demuestra como el uso de representaciones de héroes diademados y desnudos con armas grabados sobre entalles proliferará particularmente en época romana, con un uso recurrente entre tropas auxiliares. Las iconografías propuestas corresponden a Teseo (Tipo I), caracterizado por la espada, y Aquiles, con lanza y casco (tipo II). Si bien la pieza aquí presentada corresponde a una iconografía más antigua, su presencia en Tarragona podría relacionarse en este sentido.
32. T-LP3. La Pedrera-3, Collar de Tarragona 3
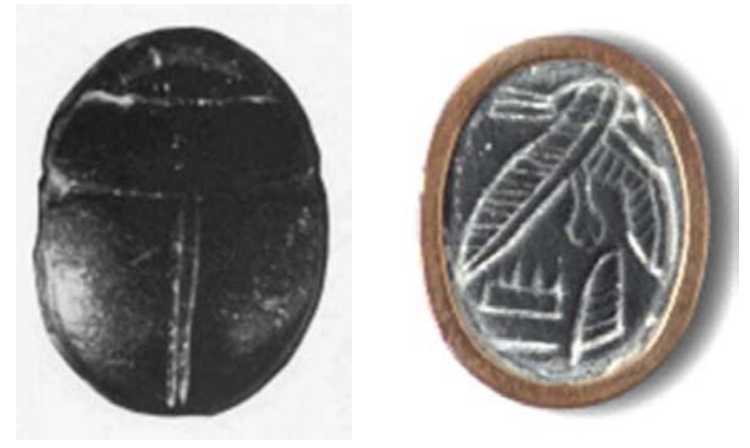

Material: Sardónice opaca, aunque I. Rodà la ha considerado una variante de serpentina sarda.

Dimensiones: Largo: 14 mm; Ancho: $11 \mathrm{~mm}$.

Perforación: Longitudinal.

Soporte: Indeterminado, aunque forma parte del collar de oro de la Sra. M. Fernández.

Tipo: Indeterminado.

Grabado: El grabado se conserva en buen estado. Realizado con profundas líneas incisas.

Procedencia: Igual que los dos ejemplares precedentes, la procedencia es indeterminada aunque se acepta como recuperado en las excavaciones y hallazgos del entorno tarraconense a lo largo del siglo XIX, particularmente en su momento final.

Comentario: La presencia de este tipo de representaciones es rara en los inventarios de piedras grabadas del Nordeste de Hispania, donde priman representaciones de tipo greco-romano y son muy raros los escarabeos de época imperial romana. Este elemento aboga a favor de que el collar pueda ser resultado de la colección de piezas del mercado anticuario internacional. Aún así, la posibilidad que el escarabeo de la Cruz de Vilabertrán y éste puedan ser hallazgos del Nordeste de Hispania, obligan a considerarlos.

Lugar de conservación: Museo Arqueológico Nacional de Tarragona, Nº. Inv.: 9682 (Nº. Inv.: de Rincomà 6971).

Conservación: Estado de conservación óptimo.

Bibliografía: Rincomà, 1982, 36, $\mathrm{n}^{\circ}$ 7; Rodà, 2010, 42-43, fig. 15 y 17b; Graells, 2011, 170, fig. 37.8.

Anverso: Dorso del escarabeo con esquema esquemático, con élitros, protórax y breve clípeo.

Reverso: Representación de halcón con las alas abiertas y garra en posición de ataque que envuelve dos símbolos, una pluma Maat y un signo rectangular.

Cronología: Se fecha entre siglo II y III d.C.

Iconografía: Representación egiptizante. Es una muestra de la influencia orientalista en el arte del Imperio Romano de ese siglo, a pesar que I. Rodà lo ha considerado dentro de las series púnicas.

\section{NA-EC1. Castillo-1, Castejón de Ágredas, Navarra}

Material: Pasta o fayenza blancuzca, a juzgar por las alteraciones de su superficie, aunque ha sido publicado como de piedra.

Dimensiones: Largo: $17 \mathrm{~mm}$; Ancho: $12 \mathrm{~mm}$; Alto: $8 \mathrm{~mm}$.

Perforación: Longitudinal, pues se aprecia el inicio en el sello, al estar parcialmente roto.

Soporte: No conservado.

Tipo: Corresponde al VI de Newberry (1907) y Vercoutter (1945, 49 y 73, fig. 2). 

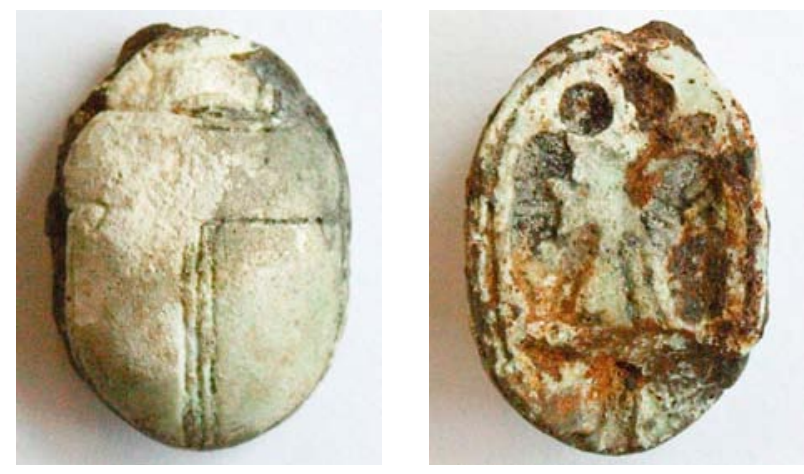

Técnica: Grabado con bastante buen estilo, con las patas esquemáticas pero bien señaladas y el fondo de las figuras con trazos paralelos oblicuos.

Procedencia: Necrópolis tumular de incineración de la necrópolis de la Edad del Hierro del Castillo de Castejón, Navarra.

Contexto: Hallado en el interior de la cista de la tumba 106, todavía inédita, pero que era la estructura funeraria de mayores dimensiones de la necrópolis (Faro, Cañada y Unzu, 2006, 53 y 60). Su ajuar contenía, entre otros objetos, un torques de bronce gallonado y una fíbula de La Tène I con pie vuelto y disco terminal (Faro, Cañada y Unzu, comunicación personal, 20.7.2011).

La necrópolis se data c. 575-300 a.C., pues ofrece broches de cinturón de un gancho, pero también ofrece fíbulas y cerámicas a torno del siglo IV avanzado o de la primera mitad del III a.C. La tumba 106 pudiera fecharse c. 500475 a.C. a juzgar por la cronología de los objetos de su ajuar, como un torques de bronce gallonado y una fíbula de La Tène I con pie vuelto y botón terminal en forma de disco (Faro, Cañada y Unzu, comunicación personal, 20.7.2011).

Lugar de conservación: Museo de Castejón de Árguedas, Inv. $\mathrm{N}^{\mathrm{o}}$ E.F. 106.12

Conservación: Conservación no muy buena, pues ofrece erosionada la parte superior izquierda del anverso y ha perdido la parte inferior del sello, pues se llega a ver la perforación transversal, además de ofrecer algunas concreciones en dicha cara que dificultan la lectura de la parte derecha del sello.

Bibliografía: AA.VV., 2002, 218, nº 2.69a; Faro, Cañada y Unzu, 2003, 73; Unzu y Faro, 2006, fig. 20.B.

Anverso: La parte superior del escarabeo ofrece el tórax separado de los élitros con una línea transversal, con triángulos sobre los ángulos externos de los élitros, mientras otra línea resalta la diferenciación de la cabeza, ésta muy erosionada, pero, al parecer, bien modelada. Los élitros quedan separados por una triple línea perpendicular.

Reverso: A la izquierda, figura sedente del dios Ptah con barba y mirando a la derecha, con un disco solar encima. A la derecha, frente al dios, se distingue otra figura, que parece ser un uraeus hacia la derecha con el cuerpo decorado con líneas paralelas y con la parte posterior de la cola arqueada hacia arriba; pudiera ser una representación de la diosa Rennut, coronada por otro disco solar. En el exergo, probablemente, un cesto $n b$ muy esquemático y roto. Una línea grabada marca el contorno de la pieza.

Paralelos e iconografía: Este escarabeo egipcio ofrece una composición característica, con buenos paralelos en Egipto, como el ejemplar de Luksor publicado por Newberry (1905, lám. 41, $\left.\mathrm{n}^{\circ} 34\right)$, con una divinidad se- dente frente a una pluma Maat y el disco solar encima. Un escarabeo de Cartago con el dios Ptah con el cetro w's procede de la necrópolis de Dermech (Vercoutter, $\left.1945,110, n^{\circ} 64\right)$, de inicios del siglo VII a.C., y otro con inscripción jeroglífica, Ptah ' $n h$ y debajo $n b$, procede de la de Saint-Louis, del siglo VII-VI a.C. (ibídem., 145, n 209). Dos escarabeos con Ptah y la pluma Maat en vez de la cobra Rennut proceden de Douimes y se han fechado en los siglos VII-VI a.C. (Vercoutter, 1945, 160, n⿳0 262-263). Otro escarabeo de Douimes ofrece una figura de Ptah con el disco solar encima y un cetro w's detrás (Vercoutter, 1945, 203, no 486).

Cronología: Siglo VI a.C., probablemente c. 600-575 a.C.

Comentario: Este escarabeo y los otros dos hallados en la necrópolis de El Castillo, de Castejón son ejemplares de Baja Época a juzgar por su estilo, en especial EC2 y EC3, ámbos datados en la XXVI dinastía, en el reinado de Psamético I (663-609 a.C) o de Apris (589-570 a.C.). Todos ellos parecen de taller egipcio, el EC1 con mayor seguridad, a juzgar por su buena calidad. Los otros dos están hechos con el mismo tipo de piedra, lo que indicaría un mismo origen, que cabe situar quizás en el Bajo Egipto, pues su estilo resulta próximo pero diferente a las piezas halladas en Náucratis.

\section{NA-EC2. Castillo-2}
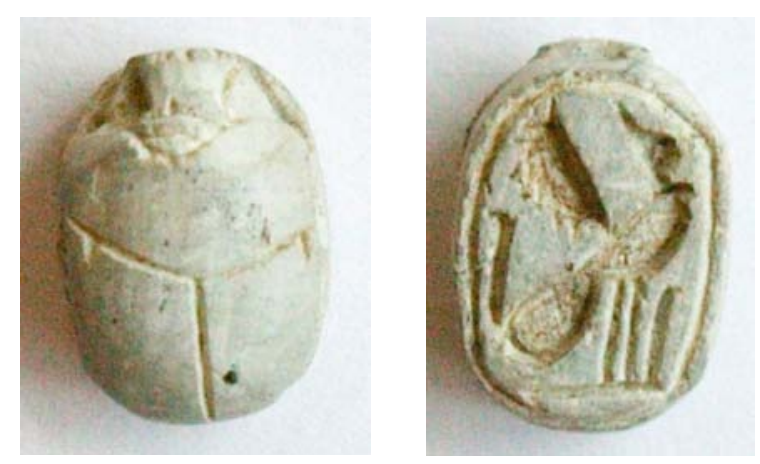

Material: Piedra, probablemente, esteatita clara, pues parece estar tallado.

Dimensiones: Largo: $10 \mathrm{~mm}$; Ancho: $7 \mathrm{~mm}$; Alto: 5,5 mm.

Perforación: Longitudinal.

Soporte: No se conserva.

Tipo: Corresponde a una variante del tipo V de Newberry (1907) y Vercoutter (1945, 49, fig. 2).

Técnica: Decoración grabada. Patas y grabado muy esquemáticos.

Contexto: Véase el escarabeo EC1, pues aparecieron en la misma sepultura.

Lugar de conservación: Museo Arqueológico de Navarra, Inv. $\mathrm{N}^{\mathrm{o}}$ E.F. 106.13.

Conservación: Buena conservación

Bibliografía: AA.VV., 2002, 218, nº 2.69b; Faro, Cañada y Unzu, 2003, 73; Unzu y Faro, 2006, fig. 20.B.

Anverso: Ofrece el tronco separado por una línea incisa simple de forma convexa, con pequeños triángulos sobre los élitros. Otra línea perpendicular separa los élitros. La cabeza aparece bien tallada, con las partes bien diferenciadas, pequeñas muescas en el borde delantero y con una forma convexa que penetra hacia el tronco.

Reverso: Figura de una esfinge con la Corona Alta del Bajo Egipto mirando a la derecha. Ofrece un ala triangular 
muy esquemática dispuesta hacia arriba y la cola que termina levemente curvada. Se sostiene sobre dos patas rectas toscas, delante de las cuales se distingue un tercer trazo vertical, quizás una pluma Maat muy esquematizada. El exergo queda marcado por una simple línea horizontal, como la que forma el contorno, ésta bastante irregular.

Paralelos: No queda lejos de los escarabeos de Náucratis por sus formas toscas y esquemáticas, así como por su ala triangular (Petrie, 1886, lám. 27, n 22-28), pero es un escarabeo de piedra, lo que parece excluir dicha procedencia.

Cronología: Siglo VI a.C., probablemente c. 600-575 a.C. Iconografía y función: Un escarabeo con esfinge y pluma Maat procede de Douimes, pero parece tener encima de la esfinge el nombre de Micerinos (Vercoutter, 1945, 198, $\mathrm{n}^{\mathrm{o}} 460$ ).

Comentario: Véase lo dicho del escarabeo EC1 y el comentario sobre el escarabeo EC3.

\section{NA-EC3. Castillo-3}
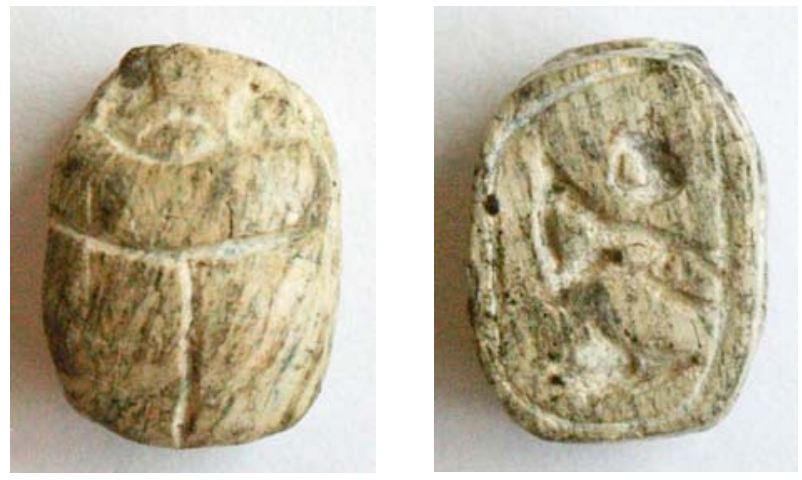

Material: Piedra, probablemente, una esteatita clara o una caliza con vetas de color verde-gris.

Dimensiones: Largo: $13 \mathrm{~mm}$; Ancho: $9 \mathrm{~mm}$; Alto: $8 \mathrm{~mm}$.

Perforación: Longitudinal.

Soporte: No se conserva.

Tipo: Corresponde al IV de Newberry (1907) y IVa de Vercoutter (1945, 49 y 72, fig. 2).

Técnica: Grabado bastante tosco, con las patas bien señaladas.

Procedencia: Hallado en el interior de la sepultura 119 de la necrópolis tumular de incineración de la Edad del Hierro.

Contexto: Procede de la EF119, estructura aparecida junto al túmulo de la tumba anterior, EF 106, lo que permite suponer una fecha no muy alejada, c. 500 a.C, aunque su ajuar contenía un fragmento de resorte de fíbula de $\mathrm{La}$ Tène, como la de la tumba EF106.

Lugar de conservación: Museo de Castejón, Inv. N ${ }^{\text {o }}$ E.F. 119.4 .

Conservación: Bien conservado.

Bibliografía: AA.VV., 2002, 218, n ${ }^{\circ}$ 89; Faro, Cañada y Unzu, 2003, 73; Unzu y Faro, 2006, fig. 20.B.

Anverso: Ofrece el tronco separado por una simple línea incisa de forma convexa y otra línea perpendicular separa los élitros. La cabeza aparece menos visible que en las piezas anteriores.

Reverso: El sello ofrece una inscripción con tres signos jeroglíficos, *W3h-íb- $R^{\star}$, que corresponden al praenomen del faraón Psamético I o al nomen de Apris (Gauthier, 1916,
104 s.; Vercoutter, 1945, 55). A la izquierda, un círculo solar muy tosco y casi cursivo, en el centro un signo $i ́ b$, también bastante esquemático, y a la derecha, el signo vasiforme ' $R$. Una línea incisa muy irregular marca el contorno.

Paralelos: Escarabeos con este nombre de faraón se conocen en Egipto, tanto en piezas de Psamético I (Newberry, 1905, lám. 38, no 10-11, 14; Hall, 1913, 251, no 25062510, 253, no 2527; Petrie, 1917, lám. LV, no 15), como de Apris (Hall, 1913, 255, no 2554), y también aparecen en Náucratis (Petrie, 1886, lám. 38, n 184-185). En Cartago son relativamente frecuentes, pues Vercoutter (1945: 76) recoge diversos ejemplares: 5 de la necrópolis de Douimès, de los siglos VII-VI a.C., 2 en cartucho asociados a otras figuras (ibídem., 94, $\mathrm{n}^{\circ} 3$ y 95, no 5), 1 asociado a una esfinge (ibídem., 195, $\mathrm{n}^{\circ} 451$ ), 1 en un sello rectangular (ibídem., 207, $\mathrm{n}^{\circ}$ 513) y otro de pasta con una inscripción que ofrece una disposición semejante al ejemplar EC3 (ibídem., 95, $\mathrm{n}^{\circ}$ 4), pieza que atribuye a Psamético I (Petrie, 1889, 60 y 62, no 1905 y 1979, de Náucratis), mientras que otra pieza de la necrópolis de Dermech II, que ya dató en el siglo V a.C., lo que no parece seguro, ofrece este nombre asociado a una figura de Maat (ibídem., 205, n 500). En la Península Ibérica se conocen otros ejemplares con este nombre de faraón, como el procedente de Mengíbar, Jaén, dispuesto en un cartucho asociado a otras figuras (García Martínez, 1997: 124, fig. 1; Padró, 1985, 135, lám. 144, nº 1.10).

Cronología: Puede considerarse del reinado del faraón Apris (589-570 a.C.), más que de Psamético I (668-609 a.C.).

Iconografía y función: Praenomen de Psamético I o nomen del faraón Apries (Vercoutter, 1945: 55), aunque estos escarabeos con nombre de un faraón cabe suponer que serían interpretados como portadores de escritura de valor mágico.

Comentario: Esta pieza permite fechar en la dinastía XXVI el escarabeo EC2, que parece proceder del mismo taller a juzgar por su estilo y por estar hecho de la misma piedra; además, como el escarabeo EC2 se halló en la misma tumba que el EC1, cabe suponer que ambos ofrecen la misma cronología y quizás procedan del mismo taller, probablemente egipcio, pero no naucrático.

\section{B-TDP1. Turó dels Dos Pins-1, Burriac, Mataró, Barcelona}

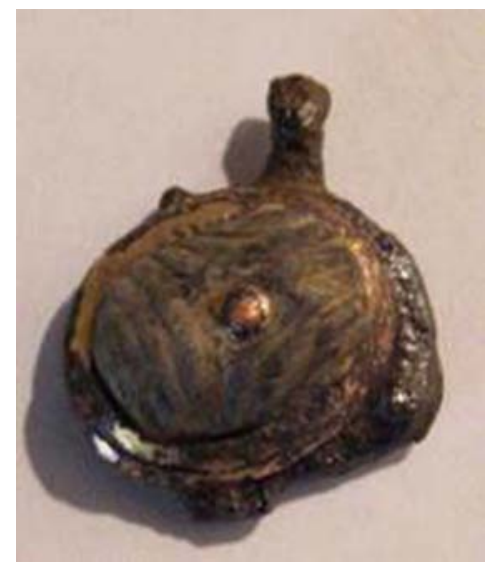

Material: Botón de marfil o hueso, con engarce de bronce. Dimensiones: Largo: $18 \mathrm{~mm}$; Ancho: $10 \mathrm{~mm}$; Alto: $6 \mathrm{~mm}$. 
Perforación: Longitudinal, pero está engarzado.

Soporte: El 'botón' está engarzado en un cabujón de bronce bañado en oro al que se fijó en un segundo momento mediante un clavo de bronce que perfora longitudinalmente el escaraboide y lo fija a una placa de hierro con anilla para poder usarlo como colgante. Esta placa de hierro impide leer los motivos o la inscripción que pudieran existir en la base del escaraboide.

Tipo: 'Botón' de forma esférica lenticular, sin adscripción tipológica (Newberry, 1906, 90; Petrie, 1925).

Grabado: Presenta grabada la parte dorsal con un dibujo complejo, pero no se observa la parte ventral, donde se supone que tendría un sello.

Procedencia: Este 'botón', procede de la excavación realizada en 1987 en la tumba T66 de la necrópolis tardoibérica del Turó del Dos Pins, próximo al Castell de Burriac en la misma comarca.

Contexto: Apareció en la tumba 66 de la necrópolis del Turó dels Dos Pins. La tumba corresponde a una estructura de tipo A1, arrasada por acción de las aguas (García i Roselló, 1993, 145-146). El ajuar de la misma lo integran dos fondos de ánfora ibérica con sendas cremaciones, una de las cuales proporcionó el 'botón' y un colgante de plata de tipo fálico. Cada una de las ánforas contenía un individuo adulto, del que no fue posible identificar el sexo.

Lugar de conservación: Museo de Mataró, №. Inv.: No conocido.

Conservación: Alterado por la corrosión del metal.

Bibliografía: Garcia i Rosselló, 1993, 145-146 y 189-190; Padró, 1995.

Anverso: Dorso trabajado a modo de semicírculos agrupados de manera decreciente en disposición radial de tres cuerpos.

Reverso: No visible, pues la placa de hierro impide leer los motivos o inscripción que pudiera existir en el sello del 'botón'.

Paralelos: Estas piezas denominadas 'boutton-seals' (Petrie, 1925) o simplemente 'botones' (Vercoutter, 1945, 204) son menos frecuentes que los escarabeos, pero están bien atestiguadas en Cartago desde el siglo VII al V a.C. Un ejemplar se ha documentado en Náucratis (Petrie, 1886, lám. XVIII, $\left.\mathrm{n}^{\circ} 25\right)$, pero deben considerarse un elemento egipcio característico desde fechas tempranas (Petrie, 1925, 2; Hall, 1913, 9, no 88 y $25, n^{\circ} 229$ ), como los escarabeos, que perduró hasta la Baja Época (Vercoutter, 1945, 204). En Hispania, a esta forma circular de botón corresponde un ejemplar CR5 aparecido en Cancho Roano (Almagro-Gorbea et alii, 2009, $\mathrm{n}^{\circ}$ CR5), otro de Mas de Mussols, MM5, y otros 5 ejemplares aparecidos en Can Canyís (vid. supra).

Cronología: El contexto general de la necrópolis se data $c$. 250-180 a.C., pero la pieza debe considerarse probablemente fabricada en Egipto en los siglos VII-V a.C., sin que se pueda precisar más, dada su estructura y estado de conservación, aunque los paralelos hallados en Hispania aconsejarían datarla posiblemente en el siglo VI a.C.

Iconografía: No resulta visible, pues queda oculta por el soporte.

Comentario: La necrópolis ofrece una cronología propia del Ibérico Reciente (250-180 a.C.), pero, como se ha indicado, la pieza debe considerarse anterior y se debe relacionar con los 'botones' de Cancho Roano y, en especial, de Mas de Mussols y de Can Canys, cuyos 5 ejemplares aparecidos denotan una relativa abundancia de este tipo de objeto, poco frecuente en Egipto e igualmente en Cartago.

\section{G-AMP1. Ampurias-1, Museo de Gerona}

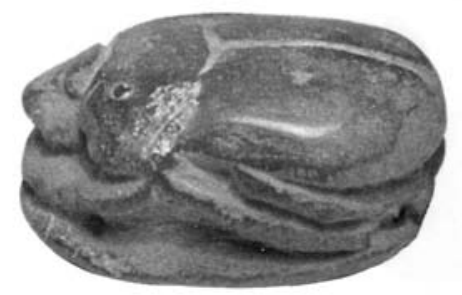

Material: Escarabeo de corazón de pasta o fayenza azulada.

Dimensiones: Largo: $51 \mathrm{~mm}$; Ancho: $33 \mathrm{~mm}$; Alto: $24 \mathrm{~mm}$.

Perforación: Cuatro perforaciones para su unión a la momia.

Soporte: Ofrece 4 perforaciones para unirlo a la momia.

Tipo: Esquema dorsal del tipo Heart Scarab.

Grabado: a molde.

Procedencia: Adquirido en 1945 como procedente de las necrópolis de Ampurias.

Contexto: Desconocido.

Lugar de conservación: Museo Arqueológico de Gerona, $\mathrm{N}^{\mathrm{o}}$. Inv.: 40.780 MAC-Girona.

Conservación: Bien conservado.

Bibliografía: Oliva, 1944, 103; Padró, 1974b, 113-115, nº 1, fig 1; 1976: 17; 1983: 33, nº 07.01, lám. XXXV; GamerWallert, 1978, 213-214 y 280-281; Graells, 2009a, no 2.23; 2010: 58 .

Anverso: Estructura del dorso con el protórax y los élitros bien marcados.

Reverso: Liso.

Paralelos: Corresponde a una producción saítica, característica de Egipto y escasamente representada fuera. Dinastías XXII a la XXVI.

Cronología: Siglos VII-VI a.C. Padró $(1983,33)$ acepta atribuirlo a la necrópolis ampuritana del Portitxol, que data en el siglo VI a.C., pero dicha procedencia no pasa de ser una mera hipótesis, dada la tipología de la pieza y la ausencia de contextos conocidos en dicha necrópolis que puedan fecharse en anterioridad al último cuarto del siglo VI a.C.

Iconografía: No ofrece sello, pues es un escarabeo de corazón (Petrie, 1914, 23, lám. 7; Bonnet, 1952, 297).

Comentario: Este escarabeo de corazón se atribuye a Ampurias, pero su procedencia del mercado de antigüedades sin referencias suficientes sobre su origen hace que su supuesta procedencia ampuritana deba ser considerada con prudencia, en especial por la rareza de este tipo de escarabeos fuera de Egipto.

\section{G-AMP2. Ampurias-2}

Material: Escarabeo de jaspe verde claro.

Dimensiones: Largo: $13 \mathrm{~mm}$; Ancho: $10 \mathrm{~mm}$; Alto: $7 \mathrm{~mm}$.

Perforación: Longitudinal.

Soporte: No se conserva.

Tipo: Escarabeo de tipo IIIa, no recogido por de Newberry (1906) y Vercoutter (1945), con élitros pero sin protórax señalado (Padró, 1983, 36).

Grabado: Grabado a buril poco diestro.

Procedencia: Excavaciones de Ampurias. 

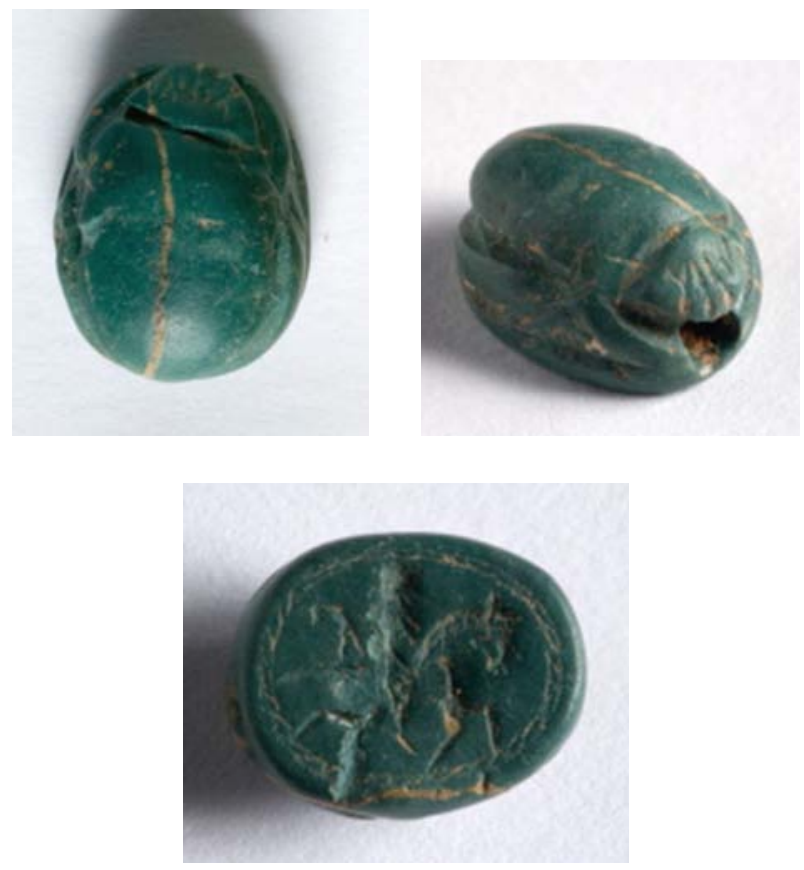

Contexto: Hallado el 17.6.1914 en una habitación al norte de la Neápolis, con cerámicas áticas de figuras rojas y un fragmento de figuras negras.

Lugar de conservación: Museo Monográfico de Ampurias, $\mathrm{N}^{\circ}$. Inv.: MAC-Empúries.

Conservación: Relativamente bien conservado pero con algunos golpes.

Bibliografía: Baqués 1976, 102-103; Padró, 1975, 115-117, no 2, fig. 2,1; 1983, 35-36, nº 07.02, lám. XXXVI; 1995; 1998; 2001; López-Grande, 1991, 194.

Anverso: Protórax no marcado y los élitros marcados por una simple línea.

Reverso: Ofrece un sello con un jinete con barba sobre un caballo que marca al paso hacia la derecha. Sobre su hombro lleva un objeto, quizá un hacha o más bien un cetro o una rama esquematizada. Toda la escena queda dentro de una cenefa de doble línea con trazos oblicuos paralelos a modo de cordón.

Paralelos: Se han señalado como paralelos piezas etruscas (Zazoff, 1968, 111, lám. 41, n 208), pero en Cartago también se han hallado escarabeos púnicos con escenas ecuestres, que parecen posteriores (Vercoutter, 1945, 227, $\mathrm{n}^{\circ}$ 603-604, lám. XVII), lo mismo que en Ibiza (Vives, 1917, no 283, 385-386, lám. XXVI.6 y 8-9; Boardman, $\left.1985, \mathrm{n}^{\circ} 157-160\right)$ y en Gibraltar (Culican, 1972, 114, fig. $3, n^{\circ}$ XXI; Boardman, 2003, 27/1), por lo que puede considerarse una temática ampliamente representada en escarabeos fenicios (Boardman, 2003, 27/21-23) y púnicos, en especial de Cerdeña (Pisano, 1996; Boardman, 2003, 27/7-16).

Cronología: Padró (1975, 116; 1983: 35) lo fecha en el siglo IV a.C. por haber sido hallado en un nivel que ofrecía cerámica ática de figuras rojas, pero su estilo parece arcaizante a pesar de su mala calidad, por lo que no se debe excluir una fecha en la segunda mitad del siglo $\mathrm{V}$ a.C.

Iconografía: Se trata de una figura de estilo helenizante, que cabría relacionar con el tema de la heroización ecuestre en el ámbito púnico (Fantar, 1966).

\section{G-AMP3. Ampurias 3}
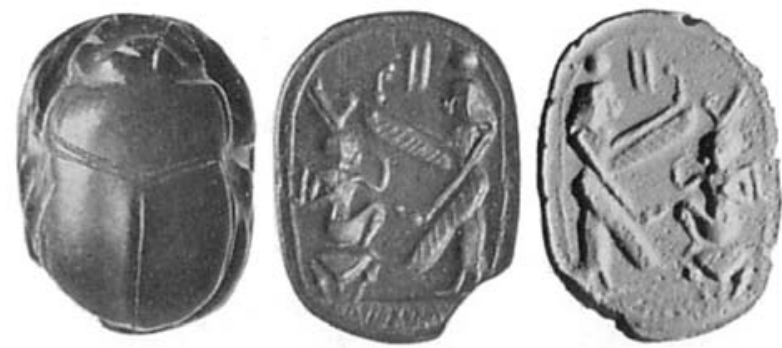

Material: Escarabeo de piedra dura, verde oscuro, con restos de pintura blanca.

Dimensiones: Largo: 15,5 mm; Ancho: $11 \mathrm{~mm}$; Alto: 7,5 $\mathrm{mm}$.

Perforación: Longitudinal.

Soporte: No se conserva.

Tipo: Escarabeo de tipo V de Newberry (1906) y de Vercoutter (1945, fig. 2, 73).

Grabado: Grabado con soltura, pero algo descuidado. Patas bien señaladas.

Procedencia: En la documentación del Museo Arqueológico de Barcelona sólo se señala que procede de Ampurias, por lo que puede tratarse tanto de un hallazgo casual como proceder de una compra a un coleccionista, en cuyo caso no se debe excluir que pudiera proceder de las necrópolis de Ibiza, donde este tipo de escarabeo es característico.

Contexto: Desconocido.

Lugar de conservación: Museo Arqueológico de Barcelona, $\mathrm{N}^{\mathrm{o}}$. Inv.: MAC Barcelona 268.

Conservación: Bastante bien conservado, pero con algunas melladuras y rota la parte inferior derecha del sello.

Bibliografía: Padró, 1975, 116-119, n 3, fig. 2.2; 1983, 3639, nº 07.03, lám. XXXVI.

Anverso: Clípeos bien marcados, protórax señalado por una doble línea curva, mientras que los élitros quedan separados por una línea simple.

Reverso: El sello representa a Horus niño (Harpócrates) tocado con la corona pschenty del Alto y el Bajo Egipto sentado en una flor de loto mirando a la derecha. Frente a él está la diosa Isis coronada por el disco solar con las alas y los brazos extendidos en actitud protectora con una pluma maat en cada mano. Encima del ala, en el campo, un doble trazo vertical. En el exergo, el signo $n b$ relleno de reticulado. Alrededor de la escena, una fina línea grabada con poca destreza.

Paralelos: Piezas con una escena similar han aparecido en Cartago, como el escarabeo de cornalina procedente de Dermech fechado en el siglo VI a.C. (Vercoutter 1945, $240, n^{\circ} 658$, Láms. XVI y XVIII) y también se han hallado en Ibiza (Vives 1917, Pl. XXIV. 3-4, 7; Boardman, 1985, 40, lám. VII, nº 43-44), pues debe considerarse un tema característico de escarabeos fenicios (Boardman, 2003, 6X/9 y 15-18). El doble trazo en la parte superior del campo ha sido interpretado como un posible jeroglífico (Vercoutter, 1945, 116, n 86; Padró, 1983, 37, n. 34), nt $r$ nfr, "buen dios". Este escarabeo debe considerarse de un taller púnico y la piedra verde empleada es característica de los talleres sardos.

Cronología: Siglo V a.C. o inicios del IV a.C. 
Iconografía: Corresponde a un modelo iconográfico originario de Egipto, ya que representa a Isis protegiendo a Harpócrates-Horus Niño, tema que, como la escena de Isis amamantando a Horus, pasó a ser popular en el mundo púnico.

Comentario: Este escarabeo AMP 3 y el AMP4, muy semejante, aunque atribuidos a Ampurias, sus características y su procedencia a través del mercado de antigüedades plantean la duda de que también pudieran proceder de Ibiza.

\section{G-AMP4. Ampurias-4}

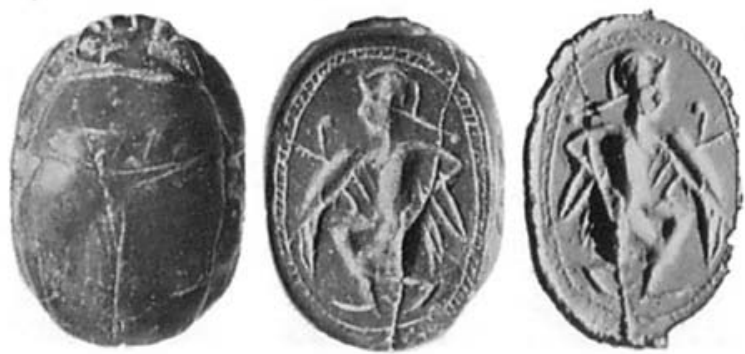

Material: Escarabeo de jaspe verde.

Dimensiones: Largo: $16 \mathrm{~mm}$; Ancho: 11,5 mm; Alto: $9 \mathrm{~mm}$. Perforación: Longitudinal.

Soporte: No se conserva.

Tipo: Escarabeo de tipo V de Newberry (1906) y de Vercoutter (1945, fig. 2.73).

Grabado: A buril, pero con un estilo descuidado que ha producido una figura algo tosca.

Procedencia: Ampurias o Ibiza? (vid. supra, AMP3).

Contexto: Desconocido.

Lugar de conservación: Museo Arqueológico de Barcelona, $\mathrm{N}^{\mathrm{o}}$. Inv.: MAC Barcelona 269.

Conservación: Ofrece golpes y una fractura longitudinal, aunque la pieza está completa.

Bibliografía: Padró 1975, 119-120, no 4, fig. 2.4; 1983, 3940, nº 07.04, lám. XXXVI; Graells, 2009a, nº 2.23.

Anverso: Esquema dorsal con los clípeos bien marcados, protórax señalado por una doble línea curva, mientras que los élitros quedan separados por una línea simple.

Reverso: El reverso ofrece un guerrero desnudo que lleva una clámide muy esquemática sobre los hombros. Camina hacia la izquierda con la cabeza cubierta por un casco semiesférico con nuquera o por un gorro con una larga borla y va armado con un escudo redondo, visto de perfil, y probablemente con una espada. Delante del escudo se aprecia un elemento ramiforme, como si portara además una rama. La figura ofrece las piernas algo encogidas para adaptarse al sello, lo que da cierta sensación de tosquedad. La escena está rodeada por una cenefa hecha con dos líneas paralelas rellenas de trazos paralelos oblicuos.

Paralelos: La figura del guerrero puede considerarse derivada de un hoplita de estilo severo, como en escarabeos publicados por Zazoff (1968, 11, lám. 3, nº 6-7). Estas figuras de guerrero son características de escarabeos de Ibiza (Boardman, 1985, lám. XXVIII-XXIX, algunos también con clámide de estilo arcaico (Boardman, 1985, $\mathrm{n}^{\circ}$ 171-172). En Cartago también aparecen (Vercoutter, $\left.233, n^{\circ} 626-637\right)$, pero es muy probable que todas estas piezas procedan de talleres sardos (Burnet y Mendleson, 1987, 103). La chlamys o clámide es una estilización de la que ofrecen escarabeos de Ibiza de estilo severo de mediados del siglo V a.C. (Boardman, 1985, $\mathrm{n}^{\circ}$ 171-172) y el posible gorro con borla también aparece en escarabeos ebusitanos (Vives, 1917, 72, lám. XXIII, nº 20) y etruscos (Zazoff, 1968, 138, lám. 54, nº 293).

Cronología: Siglo IV a.C., a juzgar por su estilo.

Iconografía: La figura deriva de prototipos griegos del tardo arcaísmo y del estilo severo, pero este escarabeo ofrece un estilo tosco y amanerado, propio de talleres púnicos, en los que son características estas figuras de guerrero que cabe relacionar con ideas de heroización del difunto, probablemente helenizadas. Sin embargo, la rama que parece portar permitiría relacionar esta figura con las represerntaciones de Melqart con un cetro acabado en una hoja (Culican, 1961; Boardman, 1985, n 73), quizás como símbolo de la 'planta de la vida'. Un escarabeo con un guerrero similar procede de La Albufereta (Padró, 1983, 117, lám. LVI), lo que evidencia la popularidad de este tema de significado heroico.

Comentario: Esta pieza y la anterior, el escarabeo AMP 3, resultan bastante parecidas en su estilo y características, lo que plantean la duda de que también pudieran proceder de Ibiza, de donde habrían pasado al mercado de antigüedades.

\section{G-AMP5. Ampurias-5}
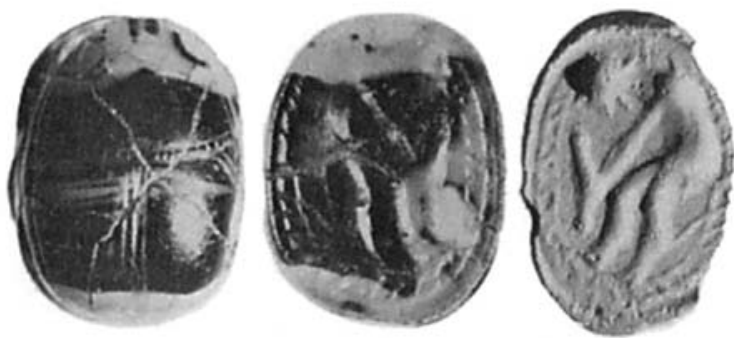

Material: Ónice con vetas de distintos colores.

Dimensiones: Largo: $13 \mathrm{~mm}$; Ancho: $10 \mathrm{~mm}$; Alto: $8 \mathrm{~mm}$. Perforación: Longitudinal.

Soporte: No se conserva.

Tipo: Escarabeo de tipo IVc de Newberry (1906) y Vercoutter $(1945,73)$.

Grabado: Descuidado y suelto, con indicios de 'globulo'. Las patas están bien labradas.

Procedencia: Se supone que de Ampurias, pero pudiera proceder del mercado de antigüedades en cuyo caso cabría atribuirle una procedencia de Ibiza.

Contexto: Desconocido.

Lugar de conservación: Museo Arqueológico de Barcelona, $\mathrm{N}^{\mathrm{o}}$. Inv.: MAC Barcelona 271.

Conservación: Bastante estropeado, agrietado y roto por la parte inferior del sello.

Bibliografía: Padró, 1974b, 120, n 5, fig. 2.7; 1983, 40, $\mathrm{n}^{\circ}$ 07.05, lám. XXXVI; Hansson, 2005, 55, n 2.4.2.b; Graells, 2009a, no 2.31 .

Anverso: Dorsal con el protórax y los élitros indicados. La separación entre los élitros es una triple línea y entre éstos y el protórax una línea transversal de puntos. En los extremos de los ángulos externos de los élitros sendos triángulos. 
Reverso: Figura de un guerrero desnudo estante hacia la derecha en actitud de ponerse la greba o cnémide de la pierna izquierda, que aparece algo adelantada y elevada. Este elemento ha sido interpretado como espada (Hansson, 2005 , 55), posiblemente como confusión entre las descripciones del ejemplar presente y el anterior. Alrededor, una cenefa en forma de doble línea con trazos oblicuos a modo de cordón.

Paralelos: La escena del guerrero poniéndose una cnémide se documenta en escarabeos desde fines del siglo VI a.C. (Boardman, 1975, $\mathrm{n}^{\circ}$ 121). Un guerrero en actitud parecida pero con una espada en el campo aparece en un escarabeo etrusco de estilo severo de muy buena calidad que representa a Aquiles armándose (Zazoff, 1968, 83, lám. 17, nº $58)$, escena que pudiera ser la representada en este escarabeo AMP5, pues se propone que a falta de una indicación mediante inscripción, todas las representaciones de personajes armados o armándose pudieran interpretarse como representaciones de Aquiles (Torelli, 2002, 134). También aparece en algún escarabeo etrusco más evolucionado (ibídem., 61, lám. 20, $\mathrm{n}^{\circ} 77$ ), ya de estilo libre de mediados del siglo V a.C., cuya disposición parece seguir fielmente, pieza inspirada en un escarabeo griego (Richter, 1968, $\mathrm{n}^{\circ}$ 90). Padró $(1983,41)$ consideró que este escarabeo AMP5 habría salido de un taller etrusco (ibídem., 118; Torelli, 2002, 103; Zazoff, 1968, n 77 y 945-950), pero este tema se reitera en diversos escarabeos ebusitanos de mejor arte (Boardman, 1985, XXVII, n 163-165).

Cronología: Aunque el modelo es de mediados del siglo V a.C., el estilo muy avanzado hace que deba fecharse en el siglo IV mejor que a inicios del III a.C. (Hansson, 2005, 55).

Iconografía: La figura del guerrero desnudo en el acto de ponerse las grebas aparece en algunas representaciones vasculares griegas del arcaísmo y del estilo severo (von Bothmer, 1985, 70 s., fig. 55-56; Barnett y Mendleson, 1987, 156, lám. 23, nº 8/3; Lissarrague, 1990, 175). En escarabeos es un tema relativamente frecuente, que quizás aluda al momento de armarse para la batalla el héroe, probablemente Aquiles, como explicita la inscripción del escarabeo de La Haya (Zazoff, 1968, 83, lám. 17, nº 58) y copian otras piezas (Zazoff, 1968, n 945-950; Torelli, 2002, 130-134). Ese carácter heroico hace alusión, quizás, al destino incierto del combate, asociado a la idea de la muerte y de paso al Otro Mundo, lo que acentúa el carácter heroico de la figura, como de otras figuras de guerrero semejantes (vid. supra, AMP4).

\section{G-AMP6. Ampurias 6}
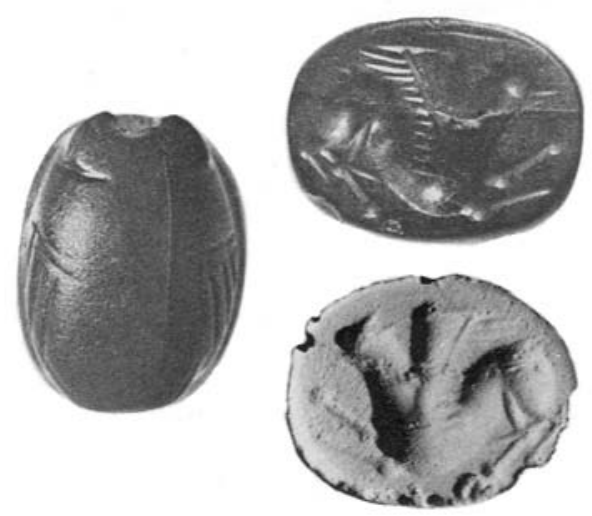

Material: Escarabeo de cornalina roja.

Dimensiones: Largo: $13 \mathrm{~mm}$; Ancho: $10 \mathrm{~mm}$; Alto: 6,5 mm. Perforación: Longitudinal.

Soporte: No se conserva.

Tipo: Escarabeo de tipo III de Newberry (1906) y de Vercoutter $(1945,72)$.

Grabado: Estilo suelto, con detalles a globolo.

Procedencia: Considerado de Ampurias, pero pudiera proceder del mercado de antigüedades, como las piezas anteriores (AMP3 a AMP 5).

Contexto: Desconocido.

Lugar de conservación: Museo Arqueológico de Barcelona, $\mathrm{N}^{\mathrm{o}}$. Inv.: MAC Barcelona 270.

Conservación: Fracturado longitudinalmente y bastante erosionado.

Bibliografía: Padró, 1974b, 120, nº 6, fig. 2.3; 1983, 41, $\mathrm{n}^{\circ}$ 07.06, lám. XXXVI; Hansson, 2005, 55, $\mathrm{n}^{\circ}$ 2.4.2.a; Graells, 2009a, $n^{\circ} 2.30$.

Anverso: Dorsal con el protórax indicado por dos dobles líneas convexas y los élitros con líneas longitudinales paralelas por su borde exterior.

Reverso: El sello ofrece un grifo galopando hacia la derecha. Tiene cabeza de ave, cuerpo de caballo, las alas desplegadas con las plumas indicadas por trazos horizontales paralelos y las patas a base de trazos rectos con pequeños toques de glóbulo en las uniones.

Paralelos: Procede de modelos griegos (Boardman, 1975, $\left.\mathrm{n}^{\circ} 100\right)$, pues se aparta de los egiptizantes y orientalizantes fenicios y derivados (Boardman, 2003, 15/36). Padró $(1983,42)$ ya lo consideró etrusco y hace referencia a una pieza similar aunque con otra postura (Zazoff, 1968, 137 , lám. $53, \mathrm{n}^{\circ} 288$ ), a la que se puede añadir otro escarabeo etrusco más parecido de una colección privada (Boardman, 1975, $\mathrm{n}^{\circ}$ 168). La misma postura ofrece otro escarabeo con una cabra galopando hacia la izquierda (ibídem., $\left.n^{\circ} 296\right)$ y también señala otro escarabeo de cornalina con un antílope procedente de Ibiza (Vives, 1917, 67, lám. XXII.19; Boardman, 1985, 77, lám. XXXVIII, nº 241). En Hispania, cabe señalar la presencia de un grifo en un escaraboide de Coimbra del Barranco Ancho, Murcia (García Cano, 1997, 261 s., n 5766), pero es de un estilo tardoclásico más helenizado.

Cronología: Fines del siglo IV o inicios del III a.C. (Hansson, 2005, 55).

Iconografía: El grifo es un animal mítico expandido durante el Periodo Orientalizante, pero pasó a formar parte de la mitología de los pueblos del Mediterráneo Occidental, tanto etruscos como íberos, aunque este ejemplar pudiera proceder del mercado de antigüedades.

\section{G-AMP7. Ampurias 7}

Material: Escarabeo probablemente de pasta o fayenza blancuzca.

Dimensiones: Largo: $16 \mathrm{~mm}$; Ancho: 13,5 mm; Alto: 9,5 mm.

Perforación: Longitudinal.

Soporte: No se conserva.

Tipo: Escarabeo de tipo IV ó V de Newberry (1906) y Vercoutter $(1945,73)$.

Grabado: Buena calidad, con las patas señaladas.

Procedencia: Considerado de Ampurias, pero pudiera proceder del mercado de antigüedades, como las piezas anteriores (AMP3 a AMP 5).

Contexto: Desconocido. 

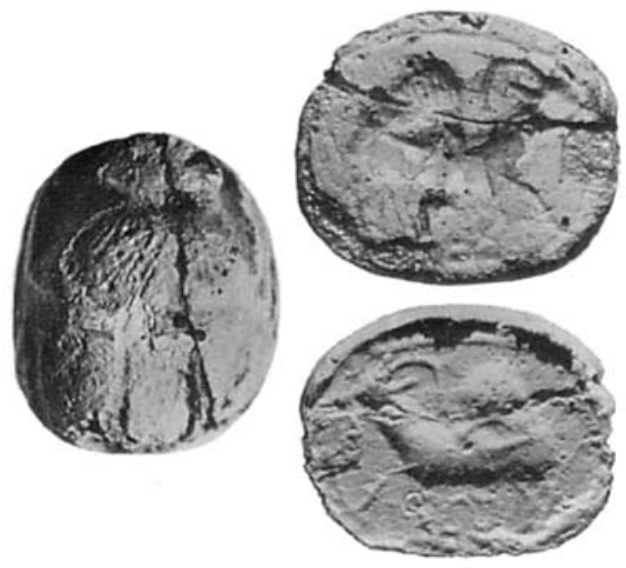

Lugar de conservación: Museo Arqueológico de Barcelona, $\mathrm{N}^{\mathrm{o}}$. Inv.: MAC Barcelona 273.

Conservación: Mal conservado y con una fractura longitudinal.

Bibliografía: Padró, 1974b, 121, nº 7, fig. 2.9; 1983, 42, nº 07.07, lám. XXXVII; Graells, 2009a, nº 2.29; 2010, 58

Anverso: Dorsal con el protórax y los élitros indicados, pero muy deteriorado.

Reverso: El sello ofrece un antílope galopando hacia la derecha, que está siendo atacado por un león? que le ha saltado sobre su lomo. Toda la escena queda dentro de una línea continua.

Paralelos: Escenas semejantes aparecen en escarabeos de Cartago (Vercoutter, 1945, 131, 159, n ${ }^{\circ} 149-150$ y n $^{\circ}$ 258), en especial en algunos con la misma escena (ibídem., $\mathrm{n}^{\circ}$ 623-625), que también aparece en Ibiza (Vives, 1917, 67 y 72, lám. XXIII.1 y XXVI.2; Boardman, 1985, 59, lám. XXIII, $n^{\circ}$ 140-141), en escarabeos que cabría atribuir a un taller púnico sardo (Barnett y Mendleson, 1987: n 27.17/11, lám. 50; 53, e.6/28). Sin embargo, el escarabeo AMP7 ofrece una simple línea de contorno, lo que, junto a su buen estilo, parece indicar un taller de otro origen, quizás fenicio.

Cronología: Siglo VII ó VI a.C., pero si realmente procede de Ampurias habría que considerar más probable una fecha c. 575-500 a.C.

Iconografía: Se trata de un motivo originario de la región sirio-palestina (Keel y Ühlinger, 1992, 166; 1998: 120, $\mathrm{n}^{\circ}$ 145a-b), donde representa al faraón atacando al enemigo, aunque también aparece en Persia (Boardman, 1975, $\mathrm{n}^{\circ}$ 83), Egipto (Vercoutter, 1945, 131) y Grecia (Boardman, $\left.1975,88, n^{\circ} 28\right)$ y pasó a ser recurrente en el mundo fenopúnico, pues aparece también en marfiles de estilo siriotartesio (Almagro-Gorbea, 2008, 428). Un escarabeo de l'Ilette, de Peyrac, Francia, ofrece un felino que ataca a un cuadrúpedo (Padró, 1983, n 04.01) y también aparece en escarabeos egipcios tardíos como el del Museo de El Cairo n ${ }^{\circ} 36456$ (Newberry, 1886, lám. VII), y, en especial, en alguno de Náucratis (Gardner, 1888, lám. XVIII,7).

El significado de la escena del león que ataca a un cáprido o un antílope es complejo. El antílope podía ser símbolo de Tammuz, en el área sirio-fenicia la cabra era el animal de Reshef (Barnett, 1957, 88) y en el área feniciopalestina lo era de la diosa de la fecundidad, Anat-Astart (Keel y Ühlinger, 1992, 166), pues la diosa como Pótnia therôn con cabras aparece desde el II milenio en Ugarit (Schaeffer, 1949, fig. 10; Lagarce, 1983, 554, lám. 99) y sendas cabras flanquean al Árbol de la Vida en una placa áurea de Tell Halaf (Bittel, 1976, fig. 308), que seguramente alude a la diosa, cuyos templos tenían rebaños de cabras o gacelas (Mallowan y Herrmann, 1974, 10, $n^{\circ} 3$ ). Bonsor $(1928,8)$ ya observó que en los marfiles hispanofenicios o tartesios, los animales responden a un ranking claramente establecido: esfinge/grifo > león > toro/cabra, lo que revela un campo mítico coherente y bien estructurado, como en Oriente, y permite adentrarse en el significado más profundo de este escarabeo. En este contexto, el cáprido atacado por un león simbolizaría al dios-rey o faraón que vence al enemigo (Keel y Ühlinger, 1998: 120, $\left.\mathrm{n}^{\circ} 145 \mathrm{a}-\mathrm{b}\right)$, cuya abstracción es el enemigo o el Mal vencido por el Bien.

\section{G-AMP8. Ampurias 8}

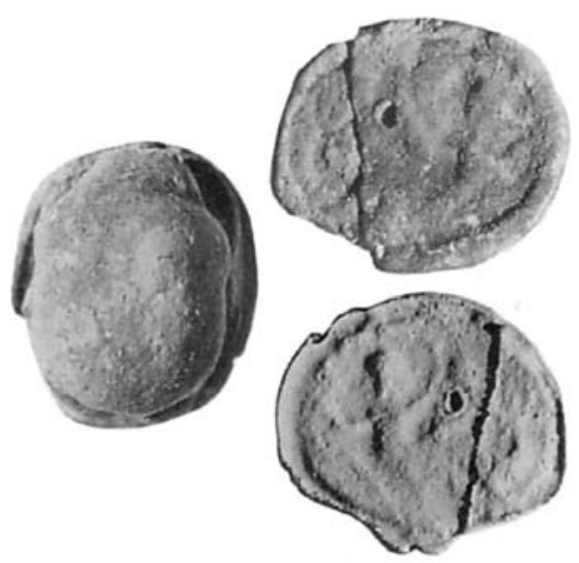

Material: Fayenza o pasta grisácea.

Dimensiones: Largo: $15 \mathrm{~mm}$; Ancho: $12 \mathrm{~mm}$; Alto: $8 \mathrm{~mm}$.

Perforación: Longitudinal.

Soporte: No se conserva.

Tipo: Escarabeo de tipo I de Newberry (1906) y Vercoutter $(1945,72)$

Grabado: Las patas están bien marcadas.

Procedencia: Véase Ampurias AMP3.

Contexto: Desconocido.

Lugar de conservación: Museo Arqueológico de Barcelona, $N^{\circ}$. Inv.: MAC Barcelona 274/9362.

Conservación: Roto y desgastada la figura del sello.

Bibliografía: Boardman, 1985, 49, n 86; Padró, 1974b, 121, $\mathrm{n}^{\circ}$ 8, fig. 2.8; 1983, 43, nº 07.08, lám. XXXVII; Graells, $2009 \mathrm{a}, \mathrm{n}^{\circ} 2.28 ; 2010,58$.

Anverso: Dorso en el que no se han trazado ni el tórax ni los élitros, aunque la pieza aparece muy desgastada.

Reverso: Padró $(1983,43)$ apreció una figura casi imperceptible por el desgaste con la cabeza alzada y los brazos abiertos. Un examen atento permite identificar un tronco humano hacia la izquierda con los brazos alzados, pero la figura se prolonga hacia atrás a modo de tritón o ser mixto cuya cola de aspecto pisciforme forma una curva y termina hacia arriba. En el campo, detrás del torso, estrella. Este escarabeo ofrece un grueso reborde alrededor del sello con la figura.

Paralelos: La forma del escarabeo es muy peculiar, pero su iconografía permite suponer que proceda de un taller fenicio más que púnico, pero no egipcio. Un ser pisciforme aparece atacado por una divinidad, probablemente Baal, en el conocido escarabeo de Ibiza 3650, de ini- 
cios del siglo V a.C. (Boardman, 1985, lám. XIII, nº 73; $2003,21 / 7$ ), pero un paralelo mejor son dos escarabeos de Ibiza con un ser pisciforme de estilo arcaico en la misma actitud de alzar los brazos (Boardman, 1985, 49, lám. $\mathrm{XV}, \mathrm{n}^{\circ}$ 85-86), uno de ellos con una estrella en el campo (ibídem., $\mathrm{n}^{\circ} 86$ ), lo que permitiría plantear que procedan del mismo taller. Aunque este tipo de ser marino aparece en escarabeos griegos desde el siglo VI a.C. (Richter, 1968, 34, n 23), esta iconografía también aparece en escarabeos de Cartago (Vercoutter, 1945, 173) y es bastante frecuente en escarabeos púnicos de Cerdeña e Ibiza que mantienen un esquema arcaico, generalmente con símbolos astrales en el campo (Boardman, 2003, $26 / 16$ a 26/35).

Cronología: Fines del siglo VI o inicios del siglo V a.C.

Iconografía: La iconografía de un ser mixto pisciforme ya aparece en relieves sirio-hititas (Bittel, 1976), pero en el mundo feno-púnico es habitual en escarabeos (Boardman, $2003, n^{\circ} 26 / 14$ y 26/15A), en los que cabría interpretarlo como el dios Yam, divinidad del mar y de la navegación. Sin embargo, dicha figura mítica también pudiera considerarse una síntesis del dios sobre un hipocampo, quizás Melqart, que ofrecen las monedas de Tiro a partir de fines del siglo V a.C. (Jenkins, 1972, 153, n 328; Nas, 1992, 320, fig. 251) y las de Biblos de c. 350 a.C. (Jenkins, 1972, 153, no 330), así como diversas terracotas púnicas (Fantar, 1966, 27), que confirman la popularidad de este motivo, en todo caso relacionado con la divinidad del mar, sea Yam o Melqart.

\section{G-AMP9. Ampurias-9}

Material: Escarabeo de cornalina.

Dimensiones: Largo: $15 \mathrm{~mm}$; Ancho: $10 \mathrm{~mm}$.

Perforación: Longitudinal.

Soporte: No se conserva.

Tipo: Escarabeo de tipo desconocido.

Grabado: No conocido.

Procedencia: Véase AMP3.

Contexto: Desconocido.

Lugar de conservación: Museo Arqueológico de Barcelona. En la actualidad, en paradero desconocido.

Conservación: Desconocida.

Bibliografía: Padró, 1974b, 121, n 9, 1983, 44; Grells, 2009a, n 2.27.

Anverso: No documentado.

Reverso: Sello con la figura de un escorpión.

Paralelos: Escarabeos con la figura de Isis-escorpión se conocen en Ibiza (Boardman, 1985, lám. XVI, nº 93) y Cerdeña (Vives, 1917, 69, lám. XXIV, nº 21 ) y escarabeos con un escorpión se documentan en Ibiza (Boardman, 1985, lám. XXII, n 136), Utica y Ard-el-Khebir, en contextos del siglo IV a.C. (Vercoutter, 1945, 236, $n^{\circ}$ 639640).

Cronología: Probablmente, siglo IV a.C.

Iconografía: El escorpión aparece en Palestina asociado desde el Hierro I a una cabra o vaca como símbolo de la Diosa Madre (Keel y Ühlinger, 1998, 125, 149 s., etc.), o de un dios (Keel y Ühlinger, 1998, 140), pero es más difícil precisar su significado en la mitología de Occidente, donde cabe suponer que pudo tener un significado apotropaico y, al mismo tiempo, también astrológico o, en todo caso, relacionado con las divinidades de la noche y las constelaciones (Keel y Ühlinger, 1998, 294, n 290).

\section{G-AMP10. Ampurias 10}

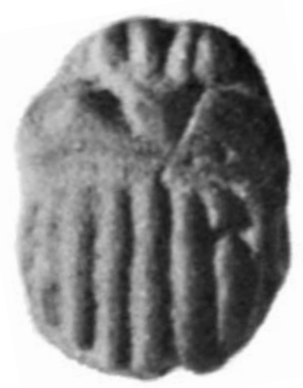

Material: Escarabeo de pasta o fayenza de color grisáceo. Dimensiones: Largo: $9 \mathrm{~mm}$; Ancho: $6 \mathrm{~mm}$; Alto: $4 \mathrm{~mm}$.

Perforación: Longitudinal.

Soporte: No se conserva.

Tipo: Escarabeo de tipo intermedio III o IV de Newberry (1906) y Vercoutter $(1945,72-73)$.

Grabado: No ofrece sello.

Procedencia: Ampurias.

Contexto: Desconocido.

Lugar de conservación: Museo Monográfico de Ampurias, $\mathrm{N}^{\circ}$. Inv.: MAC-Empúries 4550, A13.

Conservación: Superficie muy alterada.

Bibliografía: Baqués 1976, 102-103; Padró, 1974b: 122, no 10, fig. 2,6; 1983: 44, lám. XXXVII, nº 07.10; 1995; 1998; 2001; López-Grande, 1991, 194; AAVV, 2005; Graells, 2009a, n 2.26 .

Anverso: Dorso decorado con profundas acanaladuras hechas a molde.

Reverso: Liso.

Paralelos: Este ejemplar corresponde a una serie producida de manera grosera, masiva y descuidada en talleres egiptizantes tardíos, que en su mayoría son producciones de pasta con vidriados de color verde azulado. Normalmente, este grupo, presenta un gravado ventral poco profundo que en muchos casos no se conserva suficientemente. Los paralelos propuestos para dicho ejemplar se extienden en el tiempo y en el espacio encontrando un grupo muy próximo con una distribución fundamentalmente oriental y fechada entre el siglo I a.C. y II d.C. Quizás pueda considerarse como una producción colonial griega, cuyo centro productor pudo estar en la colonia milesia de Panticapea. El catálogo lo integran ejemplares de Tanais (Hodjash, 1999, 197 y $310, n^{\circ} 1636$, en el Museo di Taganrog), de Urbnisi, Georgia, de una tumba sármata de Grozny, Chechenia (Hodjash, 1999, 198 y 311, n 1654, 1655, 1656), de una tumba escita de Ustlabinskaia (Krasnodar Krai), de una tumba sarmata de Novo-Filippovka, Ucraina, y de otras de Panticapea y Bakhchisarai, en Crimea (Hodjash, 1999, 197 y 310, nº 1638-1645), de la región de Rostov, Armenia (Hodjash, 1999, 196 y 310, no 1629-1636) y del Cáucaso septentrional (Hodjash, 1999, 197 y 311, $\mathrm{n}^{\mathrm{o}}$ 1646-1653).

Sin embargo, los escarabeos sin sello son frecuentes en Cartago (Vercoutter, 1948, 175, lám. X) y también se conocen en Ibiza (Vives, 1917, 108) y en Egipto (Petrie, 1914: lám. VII y XI). En la Península Ibérica cabe señalar dos escarabeos de pasta de vidrio del anillo del tesoro de Aliseda AL5 y, probablemente, AL4 (Almagro-Gorea et alii, 2009), aunque la forma estriada de los clípeos es muy similar al escarabeo hallado en una tumba de la ca- 
lle Tolosa Latour de Cádiz en 1987 (Perdigones y Baliña, 1987), fechado a inicios del siglo V a.C.

Cronología: Si se trata de un producto del Ponto pudiera datarse entre el siglo I a.C. y II d.C., pero no puede descartarse relacionarlo con el escarabeo de Cádiz fechado a inicios del siglo $\mathrm{V}$ a.C.

Iconografía: Carece de sello, pero los escarabeos sin sello del tesoro de Aliseda AL5 y, probablemente, AL4 (Almagro-Gorea et alii, 2009) aparecen utilizados en cabujones de anillo con el escarabajo como elemento de 'adorno' mágico, función que pudiera haber tenido este ejemplar de Ampurias AMP10, tal como parece indicar su pequeño tamaño.

\section{G-AMP11. Ampurias 11}

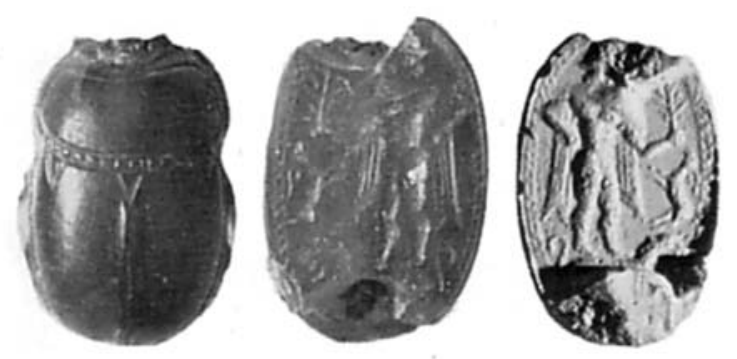

Material: Escarabeo de cornalina de color rojo oscuro.

Dimensiones: Largo: 14 mm; Ancho: 10 mm; Alto: 6 mm.

Perforación: Longitudinal.

Soporte: Insertado en un anillo de bronce muy corroido (Almagro, 1953, fig. 15,1).

Tipo: Escarabeo de tipo VI de Newberry (1906) y de Vercoutter $(1945,73)$.

Grabado: Estilo arcaico final más que severo, grabado con evidente calidad, tanto el anverso como el reverso. Las patas del animal están bien representadas.

Procedencia: Necrópolis de Ampurias.

Contexto: Inhumación 15 de la Necrópolis Martí, que consistía en una tumba de fosa cubierta de lajas de piedra, probablemente perteneciente a un niño, pues sólo medía 1 $\mathrm{m}$. El resto del ajuar consistía en un scalptorium, una fíbula de La Tène I, varios fragmentos de bronce, dos cuentas de collar de pasta de vidrio y otra de ámbar rojizo, 26 astrágalos, alguno de ellos cortados, y un lekythos italiota decorado con retícula a modo de redecilla, del 400-350 a.C. (Trías, 1967, 51-52, lám. XIII,4).

Lugar de conservación: Desconocido.

Conservación: Superficie algo alterada y fracturada y perdida los extremos superior e inferior del sello.

Bibliografía: Almagro, 1953: 43, 52, fig. 15, lám. XIII.19; Solier, 1960, 77; Padró, 1974b: 122, nº 11, fig. 2,5; 1983: 45, nº 07.11, lám. XXXVII y XXXVIII,1.

Anverso: Esquema dorsal con protórax con un reborde y separado por una línea de puntos de los élitros, a cuya altura se estrecha el cuerpo del animal. Los élitros están bien señalados y su separación queda bien marcada; en la parte superior, junto al protórax, forman un triángulo, como otros dos existentes en la parte superior externa.

Reverso: El sello ofrece una figura varonil desnuda y con barba hacia la izquierda que sostiene en la mano izquierda una rama, mientras que la derecha parece apoyarla en la cadera. Una chlamys o clámide cubre sus hombros y cae con elegancia a los lados. Esta figura aparece estante, con su pierna izquierda adelantada, sobre el dorso de un animal, posiblemente un león, quizás tumbado, cuya cola arqueada sobresale por detrás y su cabeza por delante. En el campo, en la parte situada sobre la cabeza del león y debajo del brazo del personaje aparece una gacela o cáprido corriendo dispuesto en sentido vertical. Alrededor, una moldura de trenzado de tradición orientalizante rodea todo el campo.

Paralelos e Iconografía: Padró $(1983,47)$ consideró esta pieza etrusca con influjos del estilo de glóbulos, pero debe considerarse de un taller helénico arcaico o quizás fenicio fuertemente helenizado, a juzgar por su composición y su estilo.

Este escarabeo ofrece un estilo arcaico de indudable calidad, con buenos paralelos en el mundo griego (Boardman, 1970 y 1975), como evidencia la tela del hombro, que aparece en monedas de Poseidonia (Boardman et alii, London 1967: 138,4) y Caulonia (Boardman et alii, London 1967: 138,4) de c. 530-510 a.C. Sin embargo, piezas con figuras de un estilo similar, alguna también con un animal enfrente dispuesto en sentido vertical, se han señalado en Cartago (Vercoutter, 1945, 227, 244, nº 602 y 672, lám. XVII y XIX).

Un elemento iconográfico muy peculiar es la disposición de la figura sobre un león siguiendo un esquema ampliamente utilizado para representar divinidades orientales o reyes divinizados (Bittel, 1976, fig. 285, 303, 326, etc.). La divinidad puede aparecer sobre un toro alado o ‘querubín' (Keel y Ühlinger, 1998, 340, 331b), sobre un simple toro (Keel y Ühlinger, 1998, $\mathrm{n}^{\circ}$ 285a-b) o un caballo (Keel y Ühlinger, 1998, $n^{\circ} 71-72$ ), pero lo más habitual es que se represente sobre un león, como las esculturas de bulto redondo del gran conjunto hitita de Fasillar (Bittel, 1976, fig. 264) y de los reyes divinizados sirio-hititas de Zinzirli (Orthmann, 1975, fig. 342) y Carquemish (Akurgal, 1966, fig. 24.a), éstas asociadas al culto funerario (Bonatz, 2000, 151 y ss.). La misma disposición de Baal sobre un león utiliza la 'Estela de Amrit' del Museo del Louvre, divinidad que, además, sostiene por el rabo a un león con la mano en la misma disposición que el cáprido del escarabeo. Esta estela se ha datado en el siglo V a.C. (Chéhab, 1975: fig. 122), pero Genge (1979: fig. 65) la dató c. 650 a.C., aunque parece próxima a inicios del siglo VI a.C. Este tipo de escena también aparece en escarabeos (Keel y Ühlinger, $\left.1998, n^{\circ} 71-72,285 a-b, 331 b\right)$ y en cilindro sellos siriochipriotas, como el procedente de Vélez-Málaga (García Alfonso, 1998), y prosigue en escarabeos de Ibiza con una diosa sobre un león (Boardman, 1985, 44, lám. XI, $n^{\circ} 60$ ), que confirma el uso de este esquema iconográfico en Occidente.

Respecto a la rama que lleva en la mano, es un atributo asociado a imágenes de Apolo (Jenkins, 1972, n 127), que se interpreta como una rama para la lustración, pero en este caso cabe suponer que sea una rama de cedro, lo que permitiría suponer que se trata de Baal, cuya iconografía se caracteriza por sostener una rama de cedro en su mano izquierda, como en un escarabeo de La Fonteta, LF2, en el que la divinidad aparece simbolizada por el animal del dios egipcio Seth (Olcina y Ramón, 2010: 105).

En consecuencia, la figura representada en este escarabeo AMP11 debe considerarse una divinidad oriental, aunque 
su desnudez es característica claramente helénica propia de divinidades o personajes heroizados. Por tanto, este interesantre escarabeo pudiera ser considerado fenicio, en ese caso muy helenizado a pesar de su temprana fecha, pero la desnudez de la divinidad y su estilo y composición más bien inclinan a pensar que sea obra de un taller helénico en estrecho contacto con las creencias y la iconografía de Oriente.

Cronología: La inhumación Martí 15 ofrece una datación anterior al 400 a.C. para este escarabeo, pero su estilo todavía arcaico, aunque avanzado, lleva a fecharlo hacia el último cuarto del siglo VI a.C., c. 500 a.C. como máximo, pues la disposición y el estilo de la figura es muy similar al de las monedas de Poseidonia (Jenkins, 1972: $\mathrm{n}^{\circ}$ 128; Boardman et alii, 1967, fig. 138,4) y de Caulonia (Jenkins, 1972, $\mathrm{n}^{\circ}$ 127; Boardman et alii, 1967, fig. $138,6)$, esta última con la misma disposición del manto sobre los hombros, acuñaciones datadas c. 530-510 a.C., pues la estructura y estilo de esa figura resulta claramente anterior al escarabeo de Berlín datado c. 500 a.C. (Richter, $\left.1968, n^{\circ} 122\right)$ y a las representaciones en vasos áticos del arcaismo final de inicios del siglo $\mathrm{V}$ a.C. La misma fecha se deduce del animal dispuesto en sentido vertical frente a la diviniodad, propio de escarabeos arcaicos anteriores al estilo severo, tanto griegos (Richter, 1968, n 38 y 97, c. 530 a.C.), como etruscos (Zazoff, 1968, 51, nº 33, lám. 12.33).

Comentario: Este escarabeo debe considerarse una de las piezas más interesantes hasta ahora halladas en Hispania, pues probablemente es uno de los primeros que documentan la helenización del estilo, pero manteniendo plenamente los esquemas orientales.

\section{G-AMP12. Ampurias-12}
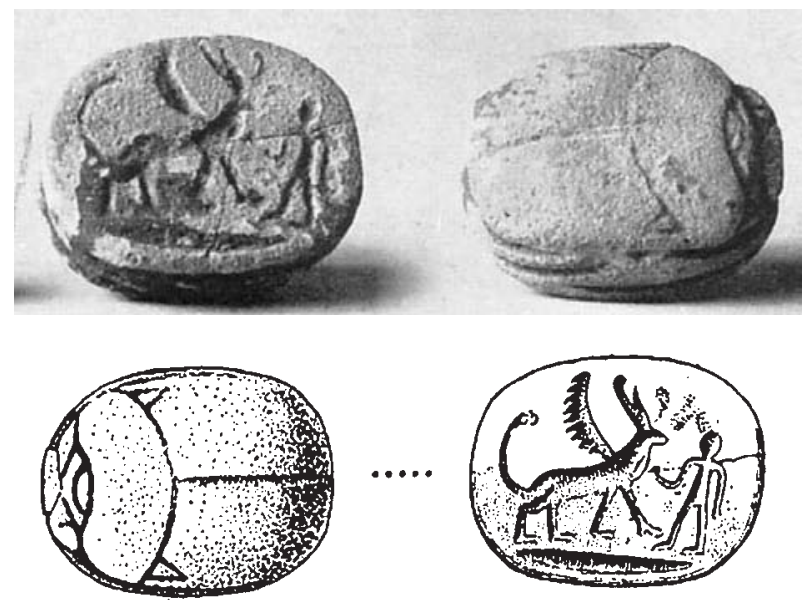

Material: Escarabeo de fayenza de color blancuzco.

Dimensiones: Largo: $32 \mathrm{~mm}$; Ancho: $24 \mathrm{~mm}$; Alto: $13 \mathrm{~mm}$.

Perforación: Longitudinal.

Soporte: No se conserva.

Tipo: Escarabeo de tipo VI de Newberry (1906) y Vercoutter (1945). El reverso de tipo E de Petrie (1917, lám. 60, no 98).

Grabado: Grabado con bastante tosquedad, pero las patas están bien modeladas. Parece obra del taller de Náucratis.

Procedencia: Ampurias, necrópolis de la Muralla NE (Noreste).
Contexto: Tumba 11 de la necrópolis de la Muralla Noreste de Ampurias (Almagro, 1955, 355-356; Graells, 2010, 105, fig. 79), fechada entre el 575 - 525 a.C. (Graells, 2010, 105). La estructura de la tumba aprovechaba una grieta en la roca, donde se contenía todo el ajuar (un escarabeo de pasta de vidrio, una fíbula de pie sobreelevado, una anilla de bronce, un colgante esferoidal, unas pinzas, un broche de cinturón de dos garfios, un simpulum, un cuchillo de hierro, una urna tetránsil realizada a mano, dos vasos de pequeñas dimensiones con perfil en $\mathrm{S}$ y dos cuencos hemisféricos, con y sin ónfalo). El ajuar permite identificar que se trata del ajuar de un personaje de élite.

Lugar de conservación: Museo de Ampurias, Nº Inv.: 2179, A12 MAC-Empúries.

Conservación: Mal conservado, pero se aprecian bastante bien sus detalles.

Bibliografía: Almagro, 1955, 362, fig. 1, lám. XVI, $\mathrm{n}^{\circ}$ 13.a-b; Solier, 1960, 78; Gamer-Wallert, 1978, 214, fig. 118, lám. 71.a-b; Arribas y Wilkins, 1969, 208; Baqués 1976, 102-103; Padró, 1974b, 123, no 12, fig. 3; 1983, 47, no 07.12, lám. XXXVII y XXXIX; 1995; 1998; 2001; López-Grande, 1991, 194; AAVV, 2005; Graells, 2008, 79-80, fig. 27; 2009a, n 2,22; 2010, 58 y 105, fig. 30 y 79 .

Anverso: Esquema del dorso con el protórax separado por una línea muy curva, mientras que otra línea perpendicular separa los élitros, que en su parte superior ofrecen sendos pequeños triángulos.

Reverso: El sello ofrece la representación de un grifo o una esfinge alada con cabeza de halcón con la doble corona pschent que camina hacia la derecha y se dirige hacia un hombre de pie situado frete a ella con un objeto recto casi horizontal en su mano derecha, que debe ser una espada, por lo que parece tratarse de una grypomachia. En el exergo, un signo $n b$ muy fino y alargado.

Paralelos: Gamer-Wallert $(1978,214)$ señala paralelos de la XXV dinastía (Petrie, 1917, lám. 60, nº 98; 1925, lám. $\left.9, \mathrm{n}^{\mathrm{o}} 314\right)$ y Padró $(1983,49)$ indica que se trata de una producción naucrática, fechable a mediados del siglo VI a.C., pues de Náucratis parece proceder el tipo de grifo (Petrie, 1886, lám. 37, nº 132-133; Gardner, 1888, lám. $18, \mathrm{n}^{\circ} 53,55$ y 60$)$ y el personaje humano con un objeto en la mano (Gardner, 1888, lám. 18, n 46-47), como también debe considerarse griega la idea de representar una grypomachia, tema extraño a la iconografía egipcia, pero no a la oriental, pues es habitual en la eboraria (Mallowan y Herrmann 1974). La representación de un grifo o esfinge con cabeza de halcón, aunque en otro tipo de escenas, se documenta en Cataluña en el ejemplar de Can Canyís CC11 y en el escaraboide del Tossal del Moro de Pinyeres, TM1.

Cronología: Siglo VI a.C., c. 600-550 a.C.

Iconografía: Frente a la interpretación de un faraón adorando una esfinge (Padró, 1983, 49), este escarabeo representa una grypomachia, que puede considerarse la más antigua documentada en Hispania. Este tema mítico tuvo un evidente éxito en la cultura ibérica, como evidencia su representación reiterada en el herôn de Porcuna, Jaén (Blanco Freijeiro, 1987; Olmos, 2000), en vasos áticos importados (Trías, 1967: 256, 471 s., 476; 1968: lám. 127,8-14, 229, 235), en la plaquita de Cabezo Lucero (Uroz, 2006), etc., hecho que se explica por formar parte de los mitos del 'Héroe fundador' (Almagro-Gorbea, 2009a; Almagro-Gorbea y Lorrio, 2011), que eran la base ideológica de la élites emergentes en la I Edad del Hierro. 


\section{G-AMP13. Ampurias-13}
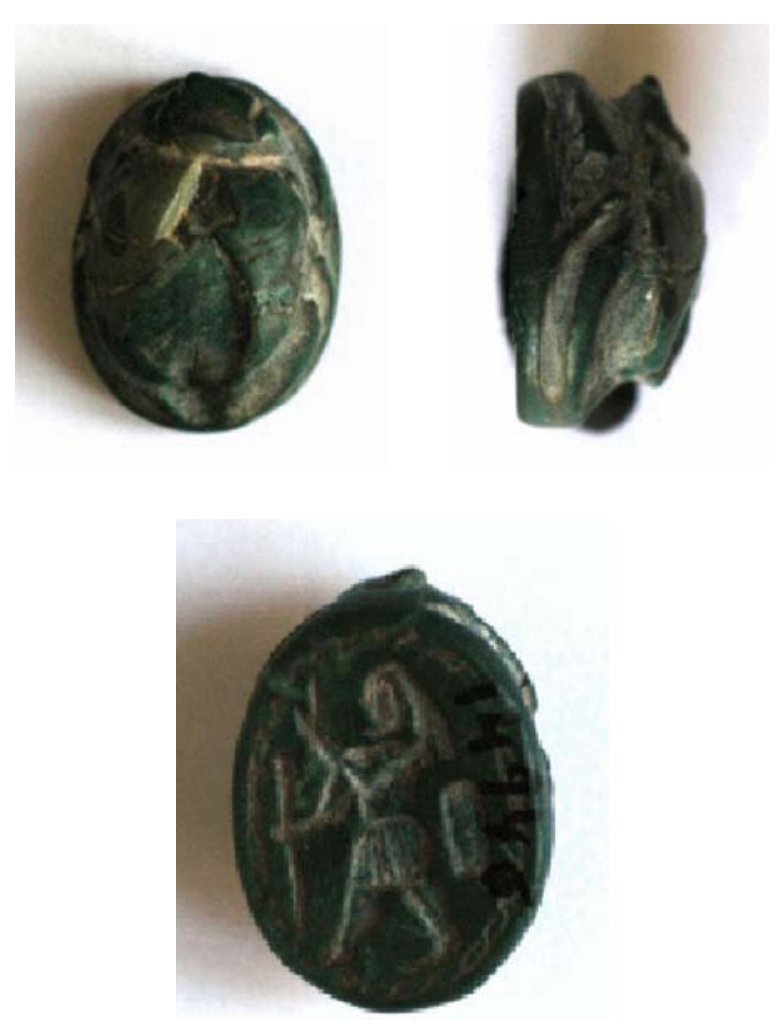

Material: Escarabeo de piedra verde muy oscura, posiblemente jaspe.

Dimensiones: Desconocidas.

Perforación: Longitudinal.

Soporte: No conservado.

Tipo: Muy mal conservado, aunque el lateral del cuerpo (patas y perfil) es articulado y completo, pero toda su superficie carece de detalles.

Grabado: Incisión a buril

Procedencia: Hallado en Ampurias antes del inicio de las excavaciones oficiales en 1907.

Contexto: Desconocido.

Lugar de conservación: Museo Arqueológico de Gerona, MAC-Girona, $\mathrm{n}^{\circ} 14946$, aunque Padró $(1983,50)$ lo considera desaparecido desde 1908.

Conservación: El dorso está mal conservado pues ofrece diversas fracturas, pero el sello presenta buen estado de conservación.

Bibliografía: Botet, 1908, 38, fig. 62; Padró, 1974b, 124, n. 59; 1983, 50-51.

Anverso: Muy mal conservado, aunque se observa el pequeño tamaño del dorso respecto a la base, así como algunos trazos decorativos conservados. El clípeo y el protórax son lisos, pero el clípeo sobresale del límite que marca la base. Los élitros no pueden caracterizarse ni tampoco su unión al protórax.

Reverso: Figura masculina de 'estilo egipcio' o egiptizante de un personaje masculino con faldellín plisado y larga cabellera que avanza hacia izquierda con el brazo izquierdo flexionado hacia arriba en actitud del saludo ritual con la mano abierta. El brazo derecho, extendido hacia abajo, sostiene un báculo recto en posición vertical. Detrás del personaje aparece un símbolo rectangular, que pudiera ser la esquematización de un cartucho real. Toda la escena se enmarca en un círculo de pseudo-sogueado inciso hecho a base de trazos en $\mathrm{Z}$.

Paralelos: Figuras masculinas egiptizantes aparecen en escarabeos púnicos, como algunos de Tharros (Barnett y Mendleson, 1987: nº 19/22 y 25/15) y de Ibiza (Boardman, 1985, lám. XI-XII, nº 62 a 66), entre los que es característica la actitud de saludo ritual (Boardman, 1985, $\mathrm{n}^{\circ} 4$, 10-11, 16, 19-20, 67 a 71, etc.). El rectángulo de la parte posterior del campo puede compararse a los pseudocartuchos que ofrecen algunos escarabeos púnicos de buen estilo, datables en el siglo VI o primera mitad del V a.C. (Boardman, 1985, $\mathrm{n}^{\circ}$ 16, 73 y 223).

J. Boardman ofrece numerosos paralelos de esta figura en escarabeos fenicios, como los ejemplares MACBarcelona 9385 (Boardman, 2003, 17/50) y MANMadrid 36993, ambos procedentes de Ibiza (Boardman, 2003, 17/51), Cagliari 19768 (Boardman, 2003, 17/54) y BM.ANE 133721 (Boardman, 2003, 17/55), ambos de Tharros, Carthago 617 (Boardman, 2003, 17/56). Además de ello, Boardman recopiló la serie de personajes-divinidades sentadas con idéntica expresión (Boardman, 2003, serie 17/1-44, con ligeras variaciones).

Cronología: Este escarabeo pudiera ser del VI o de inicios del V a.C., a juzgar por el pseudocartucho, que no aparece en escarabeos posteriores, cronología que avala la iconografía egipcia del personaje representado.

Iconografía: El personaje con faldellín es un tema egipcio que pasó a la iconografía fenicia egiptizante. La actitud del personaje, su báculo recto y el cartucho como atributos indican su carácter real, quizás como 'antepasado divinizado', idea bien documentada en estatuas hispanofenicias del siglo VI a.C. (Almagro-Gorbea y Torres, 2010: 235 s.).

\section{G-AMP14. Ampurias-14}

Material: Escarabeo de piedra verde muy oscura.

Dimensiones: No documentadas.

Perforación: Longitudinal.

Soporte: Desconocido.

Tipo: Desconocido.

Grabado: Desconocido.

Procedencia: Hallado en Ampurias antes del inicio de las excavaciones oficiales en 1907.

Contexto: Desconocido.

Lugar de conservación: Museo Arqueológico de Gerona. Desaparecido después de 1908 (Padró, 1983, 50).

Conservación: Sólo se conservaba un fragmento.

Bibliografía: Botet, 1908, 38, fig. 62; Padró, 1974b, 124, n. 59; 1983, 51

Anverso: Desconocido.

Reverso: Tema de 'estilo egipcio' o egiptizante.

Paralelos: Desconocidos.

Cronología: Desconocida, pero cabe suponer que de los siglos V al IV a.C.

Iconografía: Tema egipcio o egiptizante, pero no precisado.

\section{G-AMP15. Ampurias-15}

Material: Escarabeo de pasta o fayenza verde azulada.

Dimensiones: No documentadas.

Perforación: Longitudinal.

Soporte: Desconocido.

Tipo: Desconocido. 
Grabado: Desconocido.

Procedencia: Hallado en Ampurias en 1908 en las excavaciones emprendidas por la Comisión de Museos de Barcelona.

Contexto: Desconocido.

Lugar de conservación: Desconocido, pero Padró (1983, 52) supone que puede ser alguna de las piezas de los museos de Barcelona o Ampurias de procedencia desconocida.

Conservación: Desconocida.

Bibliografía: Botet, 1908, 39 y 62; Padró, 1974b, 124, n. 59; 1983, 52.

Anverso: Desconocido.

Reverso: Tema de 'estilo egipcio' o egiptizante.

Paralelos: Desconocidos.

Cronología: Desconocida, pero cabe suponer que de los siglos V al IV a.C.

Iconografía: Tema egipcio o egiptizante, pero no precisado.

\section{G-AMP16. Ampurias-16}

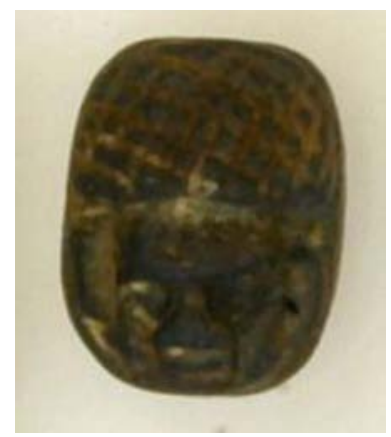

Material: Escaraboide de piedra o de pasta o fayenza de color verde muy oscuro.

Dimensiones: Desconocidas.

Perforación: Longitudinal.

Soporte: No conservado.

Tipo: Desconocido.

Grabado: Desconocido.

Procedencia: Hallado en Ampurias antes del inicio de las excavaciones oficiales en 1907.

Contexto: Desconocido.

Lugar de conservación: Museo Arqueológico de Gerona. MAC-Girona, Inv. $\mathrm{N}^{\circ} \mathrm{C} 180$. Este escarabeo constaba como desaparecido del Museo Arqueológico de Gerona después de 1908 y J. Padró $(1983,52)$ llegó a suponer que pudiera ser alguna de las piezas de los museos de Barcelona o Ampurias sin procedencia conocida.

Conservación: Indeterminada.

Bibliografía: Botet, 1908, 38; Padró, 1974b, 124, n. 59; 1983, 52.

Anverso: Cabeza de un negro.

Reverso: Tema de 'estilo egipcio' o egiptizante.

Paralelos: Este tipo de ecaraboide con cabeza humana 'negroide' aparece en Palestina desde la Edad del Hierro I-IIB, c. 1150-800 a.C. (Keel, 1997, 532-533, $\mathrm{n}^{\circ} 4$, $748-749, \mathrm{n}^{\circ} 2$ ), donde prosiguen prototipos del Bronce Reciente originarios de la XVIII dinastía (Keel, 1997, $\left.530-531, n^{\circ} 3\right)$. El tipo es bien conocido en Egipto, donde se fabricaron entre los siglos VII-VI a.C. (Jaeger, 1982, 115-116, fig. 284-286), siendo frecuentes en Náucratis (Petrie, 1886, lám. 37, $\mathrm{n}^{\circ} 4,9,11,14,26,65,83,100$, 133, 141, 142, 145; Griffith, 1888, lám. 18, nº 59-61), donde han aparecido moldes para hacerlos en un taller situado frente al Templo de Afrodita (Griffith, 1888, lám. 38, no 8-11; Griffith, 1888, lám. IV; Gorton, 1996, 177, fig. 35), lo que permite suponer que este ejemplar ampuritano pueda ser una producción naucrática. Feghali Gorton (1996, 44-45, $\mathrm{n}^{\mathrm{o}}$ 36) recoge en su tipo XVA un ejemplar de la necrópolis de Dahr el Morali que considera de tipo fenicio, aunque aparecen en tumbas púnicas de los siglos V-IV a.C. (Gorton, 1996, 48) y piezas similares han aparecido en Cartago (Vercoutter, 1945, 195-200, n ${ }^{0}$ 450-467, lám. XIII, 450-467) y también en Cerdeña (Matthiae Scandone, 1975, 53-54, lám. XII, E4, 71, lám. XVIII, $n^{\circ} 45,83$, lám. XXIII, no G16). En Hispania un ejemplar procede de Porto do Sabugueiro, en Portugal (García Martínez, 2001, n 37.01; Almagro-Gorbea y Torres, 2009, $\mathrm{n}^{\circ}$ PS1) y otra pieza similar se considera procedente de Hasta Regia, en Cádiz (García Martínez, 2001, 177).

Cronología: Siglo VI a.C.

Iconografía: El tema del sello debía ser egipcio o egiptizante, pero no se ha descrito.

\section{G-AMP17. Ampurias-17. Colección Victor Català-1}
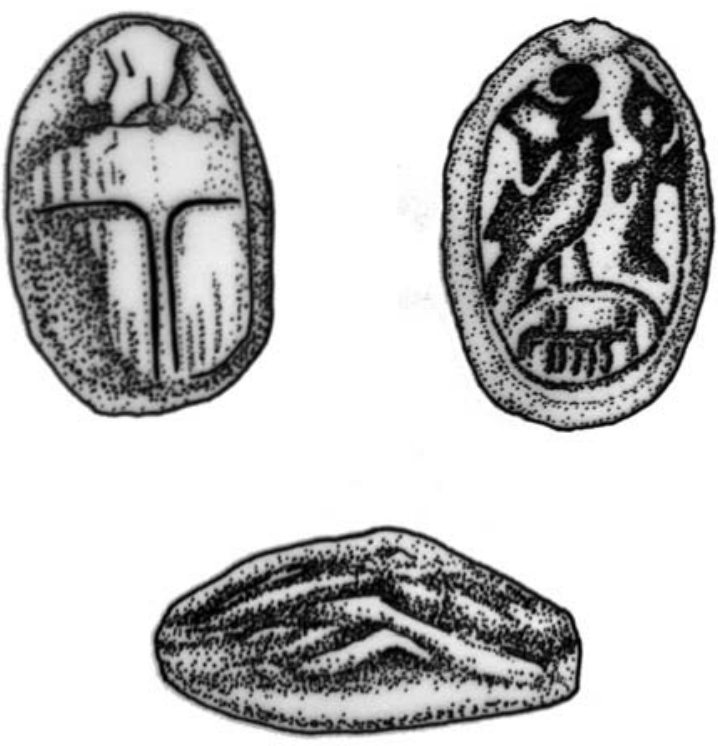

Material: Desconocido, pues el ejemplar no se conserva, aunque el tipo puede corresponder a un ejemplar de pasta o quizás en esteatita.

Dimensiones: Largo: $23 \mathrm{~mm}$; Ancho: $15 \mathrm{~mm}$; Alto: $11 \mathrm{~mm}$.

Perforación: Longitudinal, pues se aprecia una ligera escotadura en la parte del sello.

Soporte: No se conserva.

Tipo: Escarabeo de tipo II de Newberry (1906) y Vercoutter $(1945,72)$.

Grabado: Al parecer profundo y bastante tosco, según se observa en el dibujo conservado. El grabado dorsal y lateral presenta un detalle completo de los elementos diacríticos y las patas están bien marcadas, pero de forma bastante esquemática.

Procedencia: Como el resto de materiales de la colección arqueológica de la Sra. Catalina Albert o Victor Català, de La Escala, debe aceptarse la procedencia emporita- 
na, pues dicha colección estaba formada en su mayoría por piezas procedentes de Ampurias, yacimiento al que cabría atribuir este escarabeo. Aunque no hay datos para proponer una procedencia concreta, este escarabeo debe proceder de la tradición se búsqueda de materiales en el yacimiento emporitano a finales del siglo XIX, cuando se expoliaron las necrópolis situadas al Este de la ciudad romana, lo que lleva a plantear que este escarabeo AMP13, así como el siguiente AMP14, procedan de un contexto funerario.

Contexto: Desconocido.

Lugar de conservación: Colección Caterina Albert o Victor Català, de La Escala. Paradero actual desconocido.

Conservación: A partir del dibujo de C. Albert puede suponerse un buen estado de conservación. El dibujo de este escarabeo se conserva en la libreta de notas $1 \mathrm{de}$ C. Albert, realizado por la misma coleccionista. Las hojas en papel milimetrado han permitido conocer sus dimensiones.

Bibliografía: Graells, 2011, 172, fig. 40.49-51.

Anverso: El esquema dorsal presenta los élitros bien marcados y separados por una doble línea, que gira a los lados para formar la separación del tórax. El protórax y un pequeño clípeo lamentablemente no se observan bien a causa del estado de conservación del dibujo.

Reverso: Halcón de Horus? hacia la derecha, al parecer con la Corona del Alto Egipto o la Corona sekhemti del Alto y del Bajo Egipto. Delante, un signo, que parece ser la cruz de la vida, anq. El halcón se apoya sobre una línea convexa a modo de exergo, que pudiera ser el signo $n b w$, aunque también pudiera tratarse de una gran flor de loto, en ese caso mal interpretada. Toda la composición queda rodeada por una línea simple.

Paralelos: Puede proponerse un paralelo peninsular recuperado en la necrópolis de San Fulgencio-El Molar.

Cronología: Siglo VII o VI a.C.

Iconografía: El Halcón es un tema repetitivo en escarabeos fenicios egiptizantes (Boardman, 2003: tipo 9), como uno de los escarabeos de Ibiza (Boardman, 1985, 37, lám. $\left.I V, n^{\circ} 26\right)$. El signo $n b w$ de la base aparece en escarabeos de Ibiza (Boardman, 2003, n 2/19), Biblos (Boardman, 2003, 2/22), etc., pero es más habitual en escarabeos feno-púnicos de Ibiza, Tharros y Fenicia la composición del Halcón de Horus sobre flores de loto (Boardman, 2003, 9/4-5, 9/32, 9/45, 9/X8, etc.). Esta iconografía pudiera interpretarse como expresión de buenos deseos (Newberry, 1906, 78), como el ejemplar 17189 del British Museum (Newberry, 1906, 189, lám. XXXIX.8), sin excluir que pueda tratarse de un criptograma.

Este hecho lo confirma un escarabeo con halcón y anq, de piedra veteada, seguramente ágata, de fines del siglo VII a.C. hallado en Ibiza (Fernández y Mezquida, 2011: 511 s., fig. 2,5) y otro escarabeo de pasta muy próximo, pero con los signos en orden inverso (anq + Halcón), de la necrópolis de Dermech I-Ben Attar I de Cartago, fechado en el siglo VII a.C. (Vercoutter, 1945: 118, n 98). Su significado sería "Horus vive" o "Horus (da) la vida" (Vercoutter, 1945: 118), con paralelos en Egipto (Newberry, 1907: $n^{\circ}$ 37251, lám. VIII).

Comentario: Parece tratarse de un escarabeo egipcio de Baja Época, más que de una copia fenicia o naucrática, aunque no se pueda excluir esa posibilidad puesto que no se ha podido ver la pieza original.
54. G-AMP18. Ampurias-18. Colección Victor Català-2
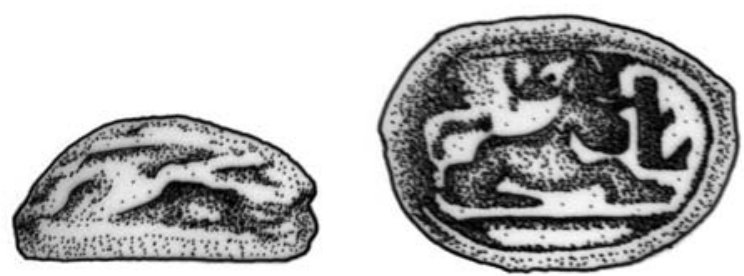

Material: Desconocido, pues no se conserva, aunque el tipo puede corresponder a un ejemplar de pasta o quizás de esteatita.

Dimensiones: Largo: $23 \mathrm{~mm}$; Ancho: $17 \mathrm{~mm}$; Alto: $12 \mathrm{~mm}$.

Perforación: En el dibujo del perfil parece apreciarse el inicio de la perforación longitudinal.

Soporte: No se conserva.

Tipo: Escarabeo de tipo II de Newberry (1906) y Vercoutter $(1945,10$ y 72$)$.

Grabado: Parece ofrecer un grabado profundo y relativamente tosco, según el dibujo conservado. Las patas están marcadas de forma esquemática.

Procedencia: Colección Victor Català, de La Escala, formada en gran medida con piezas procedentes de Ampurias, procedencia que cabría atribuir a este escarabeo, lo mismo que a la pieza anterior.

Contexto: Desconocido, pero la ausencia de excavaciones en esa época en la polis griega, particularmente en niveles arcaicos, obligan a plantear que este escarabeo, como el anterior, procedan de un contexto funerario.

Lugar de conservación: Colección Victor Català, de La Escala. Paradero actual desconocido.

Conservación: Bien conservado, según la documentación existente en la libreta de notas 1 de $\mathrm{C}$. Albert, realizado por la misma coleccionista, aunque en el borde del sello parece ofrecer una ligera melladura. Las hojas en papel milimetrado han permitido precisar sus dimensiones.

Bibliografía: Graells, 2011, 171-172, fig. 40,55-56.

Anverso: No documentado, pero el lateral es complejo y las patas permiten considerar un esquema dorsal con élitros detallados, protórax y pequeño clípeo (muy próximo al ejemplar Newberry, 1906, 73-74, fig. 71).

Reverso: Parece ofrecer una figura de esfinge tumbada hacia la derecha, con corona atef o, quizás, con sekhemti o Corona del Alto y del Bajo Egipto. Delante se aprecia un signo vertical con la base doblada, pero que pudiera ser una pluma o el vaso $h \_s$, «favor». Sobre la esfinge, en la parte superior, indicios de otro signo representados de forma más imprecisa, quizás un uraeus alado o un signo solar circular, que impide apreciar bien una ligara melladura en el borde. Por debajo, una línea horizontal debe representar en signo neb a modo de exergo. Toda la composición queda rodeada por una línea simple.

Cronología: La cronología de los paralelos y de la representación proponen una cronología de fines del siglos VII o, mejor, del VI a.C.

Paralelos e iconografía: El tipo es característico del Imperio Nuevo, en especial de Tutmosis III y Ramsés II (Boschloos, 2006, 231, no 91), pero tuvo amplia difusión pues aparece en el depósito protocorintio de 1932 de Perachora (James, 1962, 505, fig. 37.574) y también en Chipre, en Agia Irini (Gjerdstad et alii, 1935, lám. 247.9 y $26, \mathrm{n}^{\mathrm{o}} 2488$ y 2550 ), pero la aparente peor calidad de esta 
pieza ampuritana hace suponer que sea un producto de fabricación fenicia o naucrática de Baja Época.

Comentario: Como el caso anterior, parece tratarse de un escarabeo egipcio de Baja Época, sin que se pueda excluir que sea una copia fenicia o naucrática $\mathrm{y}$, como la mayor parte de los objetos de la colección arqueológica de la Sra. Catalina Albert, debe aceptarse la procedencia emporitana.

\section{G-AMP19. Ampurias-19. Museu Episcopal de Vic}

Material: Escarabeo o escaraboide de ámbar.
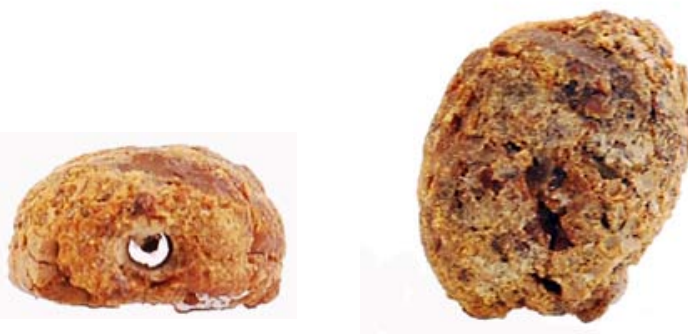

Dimensiones: Largo: $16 \mathrm{~mm}$; Ancho: $13 \mathrm{~mm}$; Alto: $6 \mathrm{~mm}$. Perforación: longitudinal, diám.: $2 \mathrm{~mm}$.

Soporte: No se conserva.

Tipo: El estado de conservación no permite una identificación tipológica. Presenta la parte ventral plana, con la curvatura del cuerpo y la perforación longitudinal asimilable a un escarabeo o a un escaraboide.

Grabado: No se observa dibujo ni grabado.

Procedencia: Recuperado en Ampurias antes del año 1918.

Comentario: La fecha de ingreso en el Museo Episcopal de Vic antes de 1918 relaciona este hallazgo con las excavaciones de Monseñor J. Gudiol en Ampurias y su relación con Víctor Català (pseudónimo de la Sra. C. Albert). Estas excavaciones, por un lado, y las relaciones con coleccionistas de La Escala permitieron a Mon. Gudiol reunir en el Museo Episcopal de Vic una pequeña colección de materiales emporitanos, entre los que destaca una notable colección glíptica. Si bien la actividad del Mon. Gudiol en Ampurias no ha sido aún objeto de un estudio detallado, la publicación de parte de la correspondencia con la Sra. C. Albert permite ver el interés del clérigo hacia la glíptica (Bofarull, 1992, 518; Graells, 2011, 165). Esa correspondencia con la Sra. Albert también muestra el interés de Mon. Gudiol por excavar en necrópolis, pues menciona las de Les Corts y de Les Coves, en uso desde finales del siglo VI a.C. Ambas informaciones permiten proponer que la pieza corresponda a un hallazgo del Mon. Gudiol en las necrópolis de Ampurias, aunque no hay datos para plantear su procedencia de ningún punto particular, si bien las necrópolis anteriormente mencionadas, en especial la de Les Coves, podrían suponer un origen verosímil.

Lugar de conservación: Museu Episcopal de Vic (MEV), $\mathrm{N}^{\circ}$. Inv.: 6546.

Conservación: Presenta mal estado de conservación, con la superficie craquelada y en algunos puntos perdida.

Bibliografía: Inédito

Anverso: Superficie lisa.

Reverso: Superficie lisa.

Cronología: Piezas de ámbar rojo de similares características morfológicas se han recuperado en contextos itálicos durante los siglos VII-VI a.C.

Iconografía: No documentada.
Comentario: Piezas discoidales o elipsoidales en ámbar son habituales en contextos itálicos, particularmente de la koiné adriática y de las distintas culturas nord-italianas. Si bien los tipos presentan una perforación transversal en su extremo superior con el fin de actuar como colgantes, la perforación longitudinal no es extraña y se reconoce en distintos contextos. Cabe decir que la forma principal es la discoidal bicónica con agujero longitudinal central y que sus usos son como cuentas de collar y únicamente los ejemplares más grandes corresponden a colgantes en posiciones destacadas (De Marinis, 2007; Miari, 2007; Nava y Salerno, 2007). Este escarabeo AMP19 no es una cuenta $\mathrm{y}$, aunque la ausencia de decoración y de detalle grabado permite considerarlo una producción itálica egiptizante, no se debe excluir que sea una pieza feno-púnica, como el escarabeo RO1 de Rosas (vid. infra).

\section{G-AMP20. Ampurias 20}

Material: Sardónice roja y blanca.
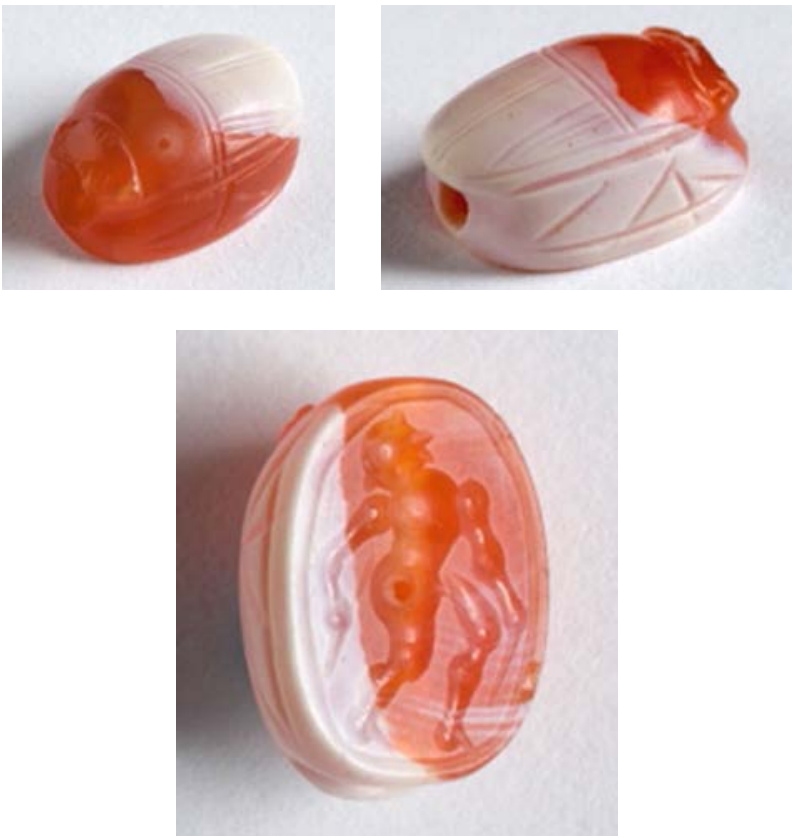

Dimensiones: Longitud: $15 \mathrm{~mm}$; Ancho: 11,2 mm; Altura: $6,7 \mathrm{~mm}$

Perforación: Longitudinal.

Soporte: No conservado.

Tipo: Etrusco, con un tipo de esquema dorsal característico de siglo IV a.C., con la decoración de detalle de los laterales superiores externos de los élitros, aunque la tipología de los esquemas dorsales de los escarabeos etruscos presenta muchos problemas, pues existen numerosas variantes y faltan publicaciones adecuandas.

Grabado: Buril y técnica de globolo.

Procedencia: Hallado por D. Domingo Gámito Font en la plaza del templo de Zeus-Serapis, el 12 de octubre de 1994.

Lugar de conservación: Museo Monográfico de Ampurias. Inventario $\mathrm{N}^{\mathrm{o}}$ : MAC-Empúries 4521.

Conservación: Buen estado de conservación. A pesar que el valor del escarabeo es el de sello, puede que el juego de colores del soporte sea aquí importante de considerar pues en la parte dorsal el color blanco ocupa los élitros y el rojo la parte delantera. La parte ventral, presenta un lateral (el 
izquierdo) en blanco dejando la mayor parte de la figura dentro del color rojo.

Bibliografía: Inédito.

Anverso: Esquema dorsal esquemático. El clípeo es sencillo con escaso detalle frontal. El protórax es liso y separado de los élitros por una doble línea incisa. Los élitros, decorados por una triple línea diagonal en los costados exteriores, están separados entre sí por una doble línea incisa. Visto el escarabeo de lado, el dorsal ocupa únicamente el tercio superior, pues la mayor parte del costado lo ocupa la franja con las patas, extremadamente esquemáticas, indicadas por sólo cuatro líneas incisas, mientras la base representa una línea fina, lisa, indicativa de una producción menor.

Reverso: Personaje masculino desnudo que avanza hacia la derecha con la cabeza ligeramente hacia atrás y con un objeto alargado en cada mano, quizás sendos puñales o cuchillos. Los detalles anatómicos están conseguidos con una combinación de glóbulos sin complementos incisos, lo que evidencia la simplicidad del trabajo y dificulta su interpretación

Cronología: La combinación de las características morfológicas del esquema dorsal y de la escena ventral permiten aproximar su cronología al paso del siglo IV al III a.C.

Iconografía: El paralelo más preciso puede considerarse el escarabeo 330 de P. Zazoff (1968, 145). El estilo a globolo de la representación ventral corresponde a un estadio avanzado, posiblemente del siglo III a.C. Respecto a la representación ventral, la ausencia de atributos impide considerar al personaje como una representación heraclea, que acostumbra a dominar este tipo de producciones, en cambio, parece más probable una representación de Kapaneus, como propuso P. Zazoff (1968, 127 y 129; Hansson, 2005, 132, P1. 30.30-32). La sugerente identificación, generalmente compartida (Torelli, 2002; Hansson, 2005; Giovanelli, 2010), de la representación de uno de los siete héroes que lucharon contra Tebas, en el momento en que es castigado por blasfemo con el relámpago de Zeus en la cabeza, o en el momento inmediatamente sucesivo, queda justificado por la representación de los brazos, caídos, y del cuerpo, en proceso de desmayo, iconografía transversal a varios estilos gracias a los que disponemos de inscripciones y combinaciones con el rayo que aseguran dicha afirmación.

De esta manera, para este ejemplar de Ampurias puede indicarse una filiación en un grupo que integran los ejemplares 247 - BM. 855 - y 249 -Paris Cab.Med. 1671 - del catálogo de P. Zazoff $(1968,127)$ y posiblemente también el no 248 - Thorv.M. 80 - del mismo catálogo y el ejemplar 192 - Colección privada - del catálogo de Boardman $(1975,45)$. Por el contrario, con tipos distintos, la iconografía de Kapaneus encontraba hasta 34 ejemplos en el catálogo de P. Zazoff $\left(1968, \mathrm{n}^{\circ}\right.$ 62-63, 65, 78, 83, 141, 247, 249-250, 832-856; Torelli, 2002, 123) que recientemente U. R. Hansson ha revisado y reintepretado, presentando ahora un catálogo de hasta quince ejemplos de representaciones del mismo héroe (Hansson, 2005, 153: nn. 237, 239, 252, 320, 359, 448, 687, 762, 814, 862, 1195, $1219,1236-1237,1245)$.

Comentario: Producción de la Italia central, posiblemente del último cuarto del siglo IV a.C.

\section{G-AMP21. Ampurias 21}

Material: Cornalina.

Dimensiones: Longitud: 14,9mm; Ancho: 11,2mm; Altura: $6,7 \mathrm{~mm}$.
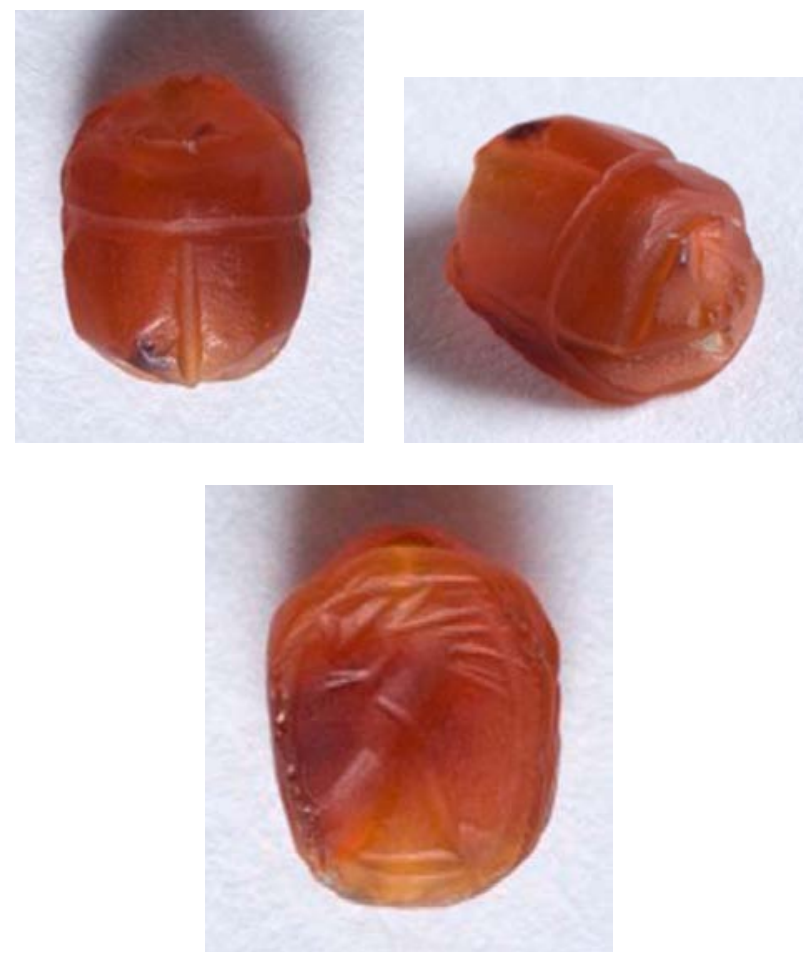

Perforación: Longitudinal.

Soporte: No conservado.

Tipo: Probablemente etrusco. El lateral muestra una representación de las patas en forma de dos triángulos.

Grabado: Buril e incisión profunda.

Procedencia: Hallado por D. Domingo Gámito en las tierras de la excavación del camino de entrada realizado el dia 26 de enero de 1988.

Lugar de conservación: Museo Monográfico de Ampurias. Inv. No: MAC-Empúries 4451.

Conservación: Buen estado de conservación.

Bibliografía: Inédito.

Anverso: Esquema dorsal extremadamente sencillo y grosero. El clípeo es liso, con una pequeña articulación de la parte frontal. Una profunda línea separa el clípeo del protórax liso y otra línea, igualmente profunda, lo separa de los élitros, a su vez también separados entre sí por una profunda línea.

Reverso: El sello muestra una figura, posiblemente alada, dentro de una orla de pseudo-sogueado. La representación es muy esquemática y parece estar orientada en sentido vertical, pues muestra una ligera línea de base en la parte estrecha del escarabeo sobre la que se sustenta la figura.

Cronología: El detalle del trabajo, especialmente el dorsal, permiten considerar este ejemplar como un trabajo decadente, posiblemente de cronología tardía: segunda mitad del siglo III a.C. o inicios del II a.C. Esta cronología se vería ratificada por la línea de base de la parte ventral, anómala en los escarabeos etruscos y, en cambio, progresivamente más utilizada en producciones romanas.

Iconografía: La extrema esquematización de la representación ventral no permite mayores aproximaciones acerca de la iconografía que la de indicar que se trata de un ser híbrido, gryllos o Mischwesen (Torelli, 2002, 103), posiblemente alado. 
Comentario: Aunque este escarabeo de cornalina de talla esquemática podría indicar una producción etrusca muy tardía, posterior a las series a globolo, nos inclinamos por considerarlo ya romano.

\section{G-AMP22. Ampurias 22}
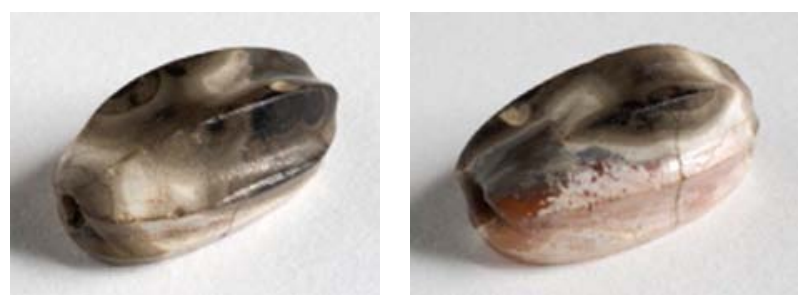

Material: Escaraboide de cuarzo gris con vetas rosadas.

Dimensiones: Longitud: $17 \mathrm{~mm}$; Ancho: 7,2 mm; Altura: 9 mm.

Perforación: Longitudinal.

Soporte: No conservado.

Tipo: Indeterminado

Grabado: Sin decoración.

Procedencia: Ampurias.

Contexto: Desconocido.

Lugar de conservación: Museo Monográfico de Ampurias. Inv. $\mathrm{N}^{\circ}$ MAC-Empúries 4489.

Conservación: Buen estado de conservación.

Bibliografía: Inédito.

Anverso: Dorso estriado, pues ofrece cuatro estrías longitudinales separadas por profundos acanalados que confieren a la pieza un aspecto agallonado.

Reverso: El plano ventral no presenta decoración.

Paralelos: Es difícil de precisar su taller de origen, pero el tipo de piedra y de trabajo hacen pensar en un producto etrusco tardío.

Cronología: La pieza aparece inventariada con una cronología entre el siglo V y IV a.C., aunque esta última fecha parece más conveniente.

Comentario: El tipo de material y la tipología de la pieza se insertan en un amplio abanico cronológico, pero en Ampurias el tipo de material se aproxima al de los escarabeos etruscos más recientes.

59. G-AMP23.Ampurias 23. Colección Raimon Casellas-1 Material: Cornalina.

Dimensiones: Desconocidas.

Perforación: Longitudinal.

Soporte: No conservado.

Tipo: Etrusco, púnico o griego.

Grabado: Indeterminado.

Procedencia: Se considera procedente del "Campo de las Cornalinas" de Ampurias, cuya existencia real se ha discutido, pues parece un término utilizado con finalidad mercantil (Graells, 2011, 190-191).

Lugar de conservación: Desconocido.

Conservación: A partir de las descripciones se intuye un buen estado de conservación.

Bibliografía: Botet i Sisó, 1879, 123; Pujol 1890: 166; Aguilar 1895: 329; Graells, 2011, 162-163.

Anverso: No documentado, sólo se indica que es una "magnífica cornelina, que afecta la forma de un escarabajo".

Reverso: Las referencias indican únicamente que corresponde a un escarabeo con "un Hércules con la clava en una magnífica cornelina, que afecta la forma de un escarabajo, del señor Casellas".

Cronología: Al no conocerse la pieza directamente, caben dos opciones acerca de su cronología: Una cronología alta, en los siglos V y IV a.C., anterior a las producciones a globolo, y una cronología posterior, de segunda mitad del siglo III a.C. La cronología antigua coincidiría con las aún importantes importaciones etruscas hacia Ampurias, mientras que para la segunda encontramos el escarabeo del collar de Tarragona (LP-2).

Iconografía: La iconografía de Héracles es habitual en escarabeos griegos, púnicos y etruscos. La combinación de la forma de escarabeo que ofrece la pieza, el uso de cornalina y el motivo representado, Héracles, hacen que en Ampurias ofrezca una alta probabilidad que se trate de una pieza etrusca de buen arte, anterior a las esquemáticas obras a globolo.

El catálogo de P. Zazoff ofrece hasta 225 representaciones del héroe tebano (Zazoff, 1968, 157 s., no 40-41, 66-68, 72, 74-76, 81, 93, 95-98, 100-103, 108, 113-114, 118, $122,159,164,166-168,175-176,178,181,183,193$, 203-204, 210, 226, 230, 232-236, 238, 262-267, 278, 287, 298, 544-719; Torelli, 2002, 123) a las que progresivamente se han incorporado nuevos ejemplares que ratifican el predominio de esta iconografía, particularmente, en las producciones etruscas (Boardman, 1975, 42-43; Hansson, 2005, 98-99).

\section{G-PE1. Peralada-1, Gerona}

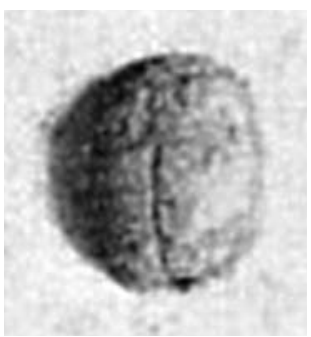

Material: Escarabeo de piedra o fayenza oscura.

Dimensiones: Desconocidas.

Perforación: Desconocida.

Soporte: No conservado.

Tipo: No documentado.

Grabado: Tallado.

Procedencia: Escarabeo aparecido en la necrópolis de Campos de Urnas de la Edad del Hierro I de Peralada.

Contexto: Desconocido.

Lugar de conservación: Paradero actual desconocido. Se conservaba en el palacio de Perelada hasta 1960.

Conservación: Desconocida.

Bibliografía: Padró, 1983, 28, nº 06.01, lám. 35; Graells, 2008, 80; 2009a, no 2.33; 2010, 58-59.

Anverso: Ofrece el protórax y los élitros bien diferenciados por una simple línea.

Reverso: No documentado.

Cronología: Su cronología se puede suponer semejante a la de la gran mayoría de los escarabeos orientalizantes de Hispania y, en concreto, de Ampurias, lo que permite datarlo a partir del primer cuarto del siglo VI a.C. (Pons y Vila, 1975), pues de la necrópolis proceden varios broches de cinturón de 2 y de 3 garfios que indican su uso a lo largo del siglo VI hasta inicios del V a.C. 
Paralelos: Padró $(1983,28)$ lo considera egipcio, lo que puede ser aceptado.

Iconografía: No documentada.

Comentario: La pieza es conocida a través de una fotografía junto a otros elementos recuperados en esa necrópolis, pero está perdida en la actualidad y únicamente se conserva la fotografía publicada por J. Padró (1982-1983; 1983: lám. $\left.35, \mathrm{n}^{\circ} 06.01\right)$.

\section{G-RO1. Rosas-1. Escarabeo de Rosas, Gerona}

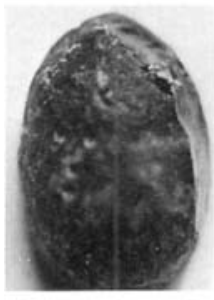

05.01
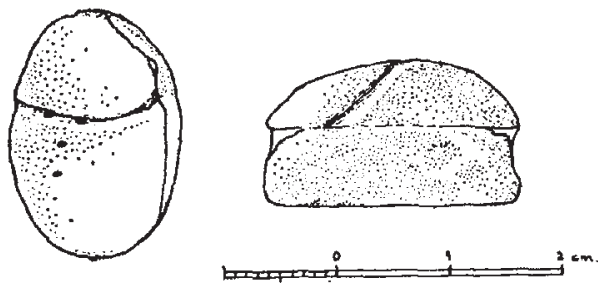

Material: Ámbar rojo.

Dimensiones: Largo: $22 \mathrm{~mm}$; Ancho: $15 \mathrm{~mm}$; Alto: $13 \mathrm{~mm}$. Perforación: longitudinal.

Soporte: No se conserva.

Tipo: III de Vercoutter (1945, 10 y 72).

Grabado: Grabado globular sencillo, conservado regularmente.

Procedencia: Recuperado en abril de 1968 durante las excavaciones del sector del Hospital (cata 2).

Comentario: El contexto ha sido considerado como nivel helenístico de la colonia griega.

Lugar de conservación: Museo Arqueológico de Gerona, $\mathrm{N}^{\mathrm{o}}$. Inv.: 41305 MAC-Girona.

Conservación: La pieza está muy afectada por erosión.

Bibliografía: Arribas y Wilkins, 1969, 208; Padró, 1969, 293 y ss.; 1974: 125; 1983: 24, lám. XXXIV; 2001; Graells, 2008, Fig 27; 2010, fig. 30.

Anverso: Ligera indicación del esquema dorsal. Se documenta ligeramente el detalle del clypeus y del tórax pero no se observan los élitros a causa del estado de conservación de la pieza.

Reverso: Ofrece una representación algo esquematizada de Bes visto de frente, con su corona de plumas característica.

Cronología: La cronología del contexto fecha la amortización del ejemplar entre el final del siglo IV y el inicio del siglo III a.C., lo que permite datarlo en el siglo IV a.C.

Iconografía: La iconografía de Bes parece corresponder a una cronología tardía, normalmente de producción no egipcia (Padró, 1983, 25; Vercoutter, 1945, 210 y 344), pues este divinidad pasó a ser muy popular en el mundo feno-púnico, lo que explica su representación en escarabeos (Boardman, 2003) y, en especial, en las monedas de Ebusus (Campo, 1976).
Comentario: La ausencia de escarabeos en ámbar en el mundo fenicio y púnico ha sido señalada por J. Padró mientras que en contextos etruscos e itálicos su presencia es relativamente mayor. J. Padró señalaba Vetulonia como núcleo etrusco con presencia de escarabeos del mismo tipo. Los recientes estudios sobre ámbar en el sureste de Francia y en la Península Itálica evidencian una abundante presencia de objetos de ámbar, pero con una cronología sustancialmente más alta a la que aquí se considera. Por otra parte, los objetos trabajados sobre ámbar raramente ofrecen motivos egipcios o egiptizantes. Por ello parece posible suponer que sea de procedencia púnica, donde el tema era tan popular.

\section{G-VIL1. Cruz de Vilabertrán-1, Vilabertrán, Gerona}

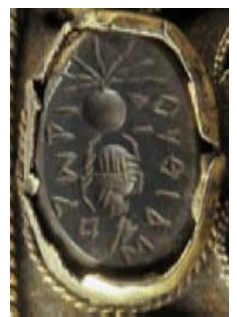

Material: Jaspe verde.

Dimensiones: Desconocidas.

Perforación: Indeterminado, aunque puede suponerse una perforación longitudinal.

Soporte: La pieza aparece engarzada en una Cruz de plata de primer cuarto del siglo XIV de producción gerundense (Sobre la Cruz, Graells, 2011, 122-128 con bibliografía).

Tipo: Indeteminado.

Grabado: Grabado en excelente estado de conservación y realizado mediante profundas líneas incisas.

Procedencia: Pieza engarzada en el disco inferior de la Cruz de Vilabertran. La Cruz, obra maestra de la joyería en plata gerundense del primer cuarto del siglo XIV, fue un regalo para las nupcias de Jaime II con Blanca de Anjou o de Nápoles en 1292. La procedencia de las piedras nos es desconocida y se divide entre dos tendencias opuestas (Para una discusión, Graells, 2011, 119-127). Por un lado los investigadores que defienden una procedencia local, véase emporitana, a partir de la proximidad del yacimiento, además de ser un regalo del conde de Ampurias. Por otro lado, la propuesta opuesta es la que considera las piedras de la Cruz de Vilabertrán como procedentes de recolectas en el Mediterráneo central y posiblemente en el entorno campano, de donde era originaria la esposa. Un argumento fundamental a favor de esta hipótesis es la comparación entre tipos de soportes representados en la Cruz y los porcentajes representados en las colecciones procedentes de Ampurias. Mientras que la Cruz carece de pastas vítreas, en Ampurias representan valores entre el 25 y $30 \%$ de los entalles.

Comentario: Aunque existen dudas sobre la procedencia originaria de este escarabeo, se ha incluido en este trabajo dada la proximidad a Ampurias.

Lugar de conservación: Cruz de Vilabertrán, conservada en la Iglesia de Santa María de Vilabertrán, Gerona.

Conservación: Excelente estado de conservación.

Bibliografía: Roulin, 1899, 207; Németh y Canosa, 2000; Canós, 2002, 158-161; Németh, 2007, 1008-1009; Mas et alii, 2008, 296; Graells, 2011, 125, fig. 18. 
Anverso: La parte dorsal no puede observarse al estar engarzada en la Cruz.

Reverso: Representación de escarabeo rodeado de inscrip-

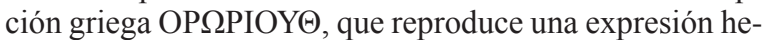
brea: "Luz de luces". Según E. Roulin $(1899,207)$ se trataría de un "Scarabée et globe solaire surmonté de rayons. Pierre curieuse par l'inscription gnostique grecque qui entoure le sujet, et qui, cependant, n'offre pour nous aucun sens. Nous avons là une gemme gnostique d'origine Égyptienne, mais de l'époque impériale romaine. Jaspis gris foncé".

Cronología: La invocación cristiana de la inscripción y su simbología gnóstica indican una fecha del siglo IV d.C., aunque Németh propone el siglo III d.C.

Iconografía: Se considera la inscripción y el motivo como una representación gnóstica de tradición cristiana.

\section{F-MON1. Montlaurès-1, Narbonnes, Aude}

Material: Piedra verde, probablemente jaspe.

Dimensiones: Desconocidas.

Perforación: Longitudinal.

Soporte: No se conserva.

Tipo: Indeterminado, pues los confusos datos acerca de la pieza dificultan una correcta adscripción.

Grabado: Según opinión de J. Padró el trabajo de grabado sería mediocre.

Procedencia: Recuperado por el Sr. Ducros en anterioridad a las excavaciones de H. Rouzaud.

Comentario: No se tienen datos acerca de las circunstancias del hallazgo ni existe un dibujo ni una fotografía.

Lugar de conservación: Indeterminado.

Conservación: Indeterminada.

Bibliografía: Gallet de Santerre, 1964, 479; Benoit, 1965, 68; Padró, 1983, 14-16, n 03.01.

Anverso: No hay datos sobre el esquema dorsal.

Reverso: Según J. Padró, ofrece una escena con una representación zoomorfa con dos pájaros o pájaro y un animal de forma poco precisa, compuesto quizás por un cuervo y un gato o zorro, que aparecen sobre un símbolo $\mathrm{nb}$ relleno de rayas. Todo el conjunto queda enmarcado por un óvalo de puntos.

Cronología: Posiblemente pueda fecharse en el siglo IV a.C., aunque los argumentos son insuficientes y deberían ampliarse siguiendo los márgenes consensuados para los escarabeos en piedra verde, principalmente púnicos y particularmente sardos, que podrían empezar en el siglo $\mathrm{V}$ a.C. y terminar en el siglo III a.C.

Iconografía: Indeterminada.

\section{F-MON2. Montlaurès-2}

Material: Cornalina.

Dimensiones: Indeterminado.

Perforación: Longitudinal.

Soporte: No se conserva.

Tipo: Esquema dorsal en representación de cabeza humana. Grabado: Interminado.

Procedencia: Recuperado por H. Rouzaud el 17 de febrero de 1907, en la ladera frente a Bougna.

Comentario: Igual que ocurre con el ejemplar Montlaurès-1, son confusos e insuficientes los datos sobre el hallazgo, que no permiten valorar su contexto originario. La ausencia de contexto obliga a tomar con cautela la propuesta de J. Padró de recurrir al comercio fenicio-púnico para explicar la presencia de escarabeos en el Sur de Francia. La au- sencia de un impacto comercial real del mundo fenicio a partir del siglo V a.C. tanto en Lattes como en Ampurias, permiten plantear otras hipótesis para explicar la presenia de estos escarabeos.

Lugar de conservación: Indeterminado.

Conservación: Indeterminado, aunque la descripción de la pieza ("of good workmanship") permite suponer que en el momento de su hallazgo la pieza estaría en buenas condiciones.

Bibliografía: Benoit, 1965, 68; Padró, 1983, 16, 03.02.

Anverso: No indicado.

Reverso: Vista frontal de una cara que en opinión de Padró, que sigue las descripciones de Rouzaud, sería obra de un buen artesano.

Cronología: Para una aproximación cronológica vid supra AMP-16, aunque la materia utilizada en el ejemplar aquí considerado obliga a situar su cronología a partir del siglo V a.C., sin mayores precisiones.

Iconografía: La reproducción de caras en posición frontal sustituyendo los esquemas dorsales habituales de los escarabeos permite una serie de consideraciones básicas a falta de poder analizar en detalle las características particulares de la pieza en concreto.

La representación de caras en posición frontal como esquema dorsal de escarabeos se documenta desde el segundo período intermedio y perduró más allá de la producción naucrática. En las producciones antiguas, los soportes corresponden a esteatita, caliza y pasta de fayenza, mientras que el uso de la cornalina y otras piedras duras empieza a utilizarse a partir del sigloV a.C.

Comentario: Su presencia en Montlaurès se atribuyó al comercio fenicio (Padró, 1983, 16), pero ni la cronología ni los materiales asociados permiten mantener dicha propuesta.

\section{F-MON3. Montlaurès-3}
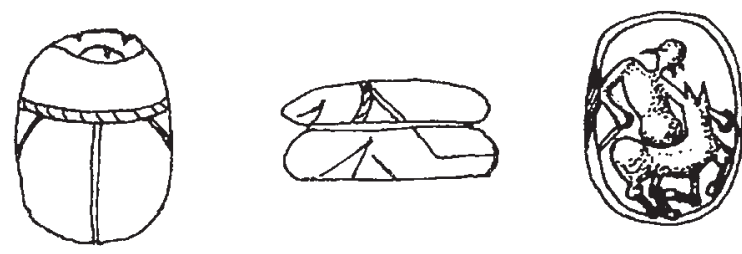

$2 \mathrm{~cm}$

Material: Cornalina roja.

Dimensiones: Según J. Padró, ofrece las siguientes dimensiones: Largo: $11 \mathrm{~mm}$; Ancho: $8 \mathrm{~mm}$; Alto: $5 \mathrm{~mm}$; según H. Guiraud sus dimensiones son: Largo: $12 \mathrm{~mm}$; Ancho 9 $\mathrm{mm}$; Alto: $7 \mathrm{~mm}$.

Perforación: longitudinal.

Soporte: No se conserva.

Tipo: D según AGDS-II, 49-50.

Grabado: Incisión mediante técnica de globolo.

Procedencia: Indeterminado, aunque perteneciente a la colección Charra, quien lo adquirió a H. Rouzaud como pieza recuperada en Montlaurès.

Comentario: J. Padró detectaba la no correspondencia de esta pieza con las que Rouzaud describe como recuperadas en Montlaurès, por lo que no es segura su adscripción a Montlaurès, aunque se incluya con las piezas de ese yacimiento. 
Lugar de conservación: Museo Arqueológico de Narbona.

Conservación: Buen estado de conservación.

Bibliografía: Benoit, 1965, 68; Padró, 1983, 16-17, $\mathrm{n}^{\circ}$ 03.03; Guiraud, 1973, 177-178, nº 6 ; 1980, 80, nota 56; 1988, 153, lám. XXXIX, nº 558.

Anverso: Esquema dorsal de tipo VI, con el tórax y los élitros separados por un línea sogueada y los élitros, que presentan un tríangulo en la parte superior, por dos líneas.

Reverso: Según opinión de J. Padró el ejemplar presentaría un jinete y caballo a derecha, dentro de un óvalo, opinión que comparte también H. Guiraud. Algunas precisiones deben realizarse y cambiar la interpretación. La no representación de las piernas del personaje resulta anómala en representaciones de jinetes (Christie's-NY, lote 9538 de 6.12.2000; Spier, 1992, n 153-155, del J. Paul Getty Museum; Zazoff, 1968, $\mathrm{n}^{\circ}$ 283, del Museo Nazionale Romano $\mathrm{N}^{\mathrm{o}}$.Inv.:103174) y obliga a suponer que se trate de una representación distinta, en la que el primer plano lo ocupa un cuadrúpedo, posiblemente un cánido y un segundo plano con un personaje humano armado con un posible pedum (quizás una espada o clava) en la mano derecha.

Cronología: Guiraud y Padró lo fecharon en el siglo III a.C., aunque su cronología debe situarse en el siglo IV a.C. a partir de los paralelos que suponen los escarabeos etruscos de tipo globolo.

Iconografía: La composición puede interpretarse de diferentes maneras. Puede considerarse una mera escena de caza, pero bajo la que caben dos posibles lecturas mitológicas: una es relacionar el mensaje del sello con su función y proponer una lectura en la que el sello permitiera reconocer al propietario, por lo que quizás representaría la escena de la Odisea en la que Ulises es reconocido por su leal perro Argosiglo. Otra propuesta permite identificar al personaje con Héracles y el perro con Cerbero. A favor de esta segunda opción está la frecuente representación de Héracles en los escarabeos etruscos, hasta un $59 \%$ de los casos (Grummond, 2010, 15) y la existencia de hasta 11 ejemplos con representaciones próximas (Zazoff, 1968; Torelli, 2002, 125).

La escena tiene un paralelo próximo pero de procedencia indeterminada (Zazoff, 1968, 136, n ${ }^{\circ} 283$, lám. 53), aunque la composición ofrece mayores similitudes en ejemplares de Malibu (Hansson, 2005, Pl. 7.31), Cetamura (De Grummond, 2010) y posiblemente de Gabii (AlmagroGorbea, 1982), interpretados como representación de Heracles y Cerbero. La composición con el perro encuentra paralelos en 1 ejemplar del MAN-Nápoles (Zazof, 1965, n 285), 2 de Boardman (1975, no 195-196) y 2 del J. Paul Getty Museum (Spier, 1992, n $\left.^{\circ} 158-159\right)$. El arma encuentra paralelos en Malibu y en Cetamura (Hansson, 2005, Pl. 7.31; De Grummond, 2010, 14-15).

Este ejemplar es particularmente ilustrativo de la difusión del imaginario iniciático aristocrático: la caza, tema muy frecuente en época tardoclásica, como lo indican hasta 9 representaciones que se han denominado 'escenas de joven y perro' (Torelli, 2002, 111).

Comentario: J. Padró $(1983,17)$ aceptó con prudencia que este ejemplar fuera una producción etrusca.

\section{F-MON4. Montlaurès-4}

Material: Pasta verde, vidriada.

Dimensiones: Largo: $11 \mathrm{~mm}$; Ancho: $8 \mathrm{~mm}$; Alto: $7 \mathrm{~mm}$.

Perforación: Longitudinal.
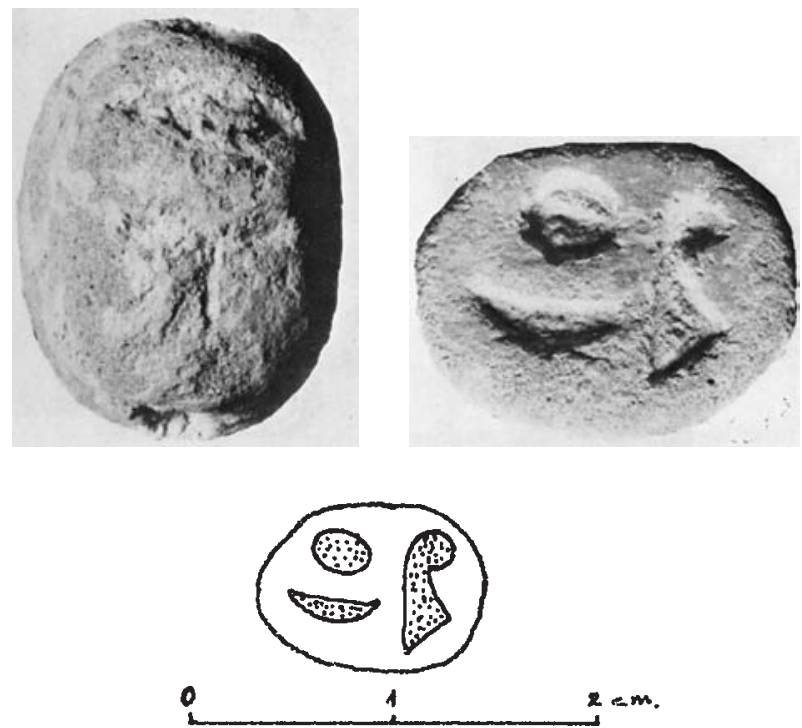

Soporte: No se conserva.

Tipo: Esquema dorsal de tipo IVa

Grabado: A molde.

Procedencia: Procede de una sepultura de neonato, recuperada durante las excavaciones de J. Giry en 1961, en el lado sur del yacimiento, dentro de una estructura de $4 \mathrm{x}$ 4,5 m; aunque las ofrendas de ajuar en neonatos son raras (Dedet, 2008, 153-154), su presencia obliga a considerarlo como un individuo infantil de primer año o pre-Infans I.

Comentario: En su momento se propuso la estructura como un pequeño santuario con un sacrificio infantil, aunque el catálogo de hallazgos de sepulturas infantiles en la región y su variación de tipos permite hoy descartar esa primera interpretación (Graells, 2009b, con una panorámica y bibliografía).

Lugar de conservación: Colección Giry en la Iglesia Parroquial de Nissan.

Conservación: Correcto.

Bibliografía: Padró, 1983, 17-18, nº 03.04.

Anverso: El tórax y los élitros están delimitados por una fina línea.

Reverso: Jeroglífico de $N b-M \int ' t-R$ ' interpretado como "rey del alto y bajo Egipto", nombre de Amenhotep III.

Cronología: El contexto del hallazgo sitúa la pieza en el siglo VI a.C., que coincide con las características de fabricación, asimilable a producciones naucráticas.

Iconografía: Los paralelos para dicha iconografía y jeroglíficos en Can Canyís 7.

Comentario: Su presencia en Montlaurès se atribuyó al comercio fenicio (Padró, 1983, 16), pero ni la cronología ni los materiales asociados permiten mantener dicha propuesta.

\section{F-MUR1. Murviel-lès-Montpellier-1, Hérault}

Material: Piedra calcárea.

Dimensiones: Longitud: $10 \mathrm{~mm}$.

Perforación: Indeterminado.

Soporte: No conservado.

Tipo: No corresponde a los tipos de Newberry (1906) ni de Vercoutter (1945).

Grabado: Realizado con detalle. El lateral presenta un cuerpo muy detallado, con importante relieve de las extremidades sobre restos de un podio, aparentemente liso, 

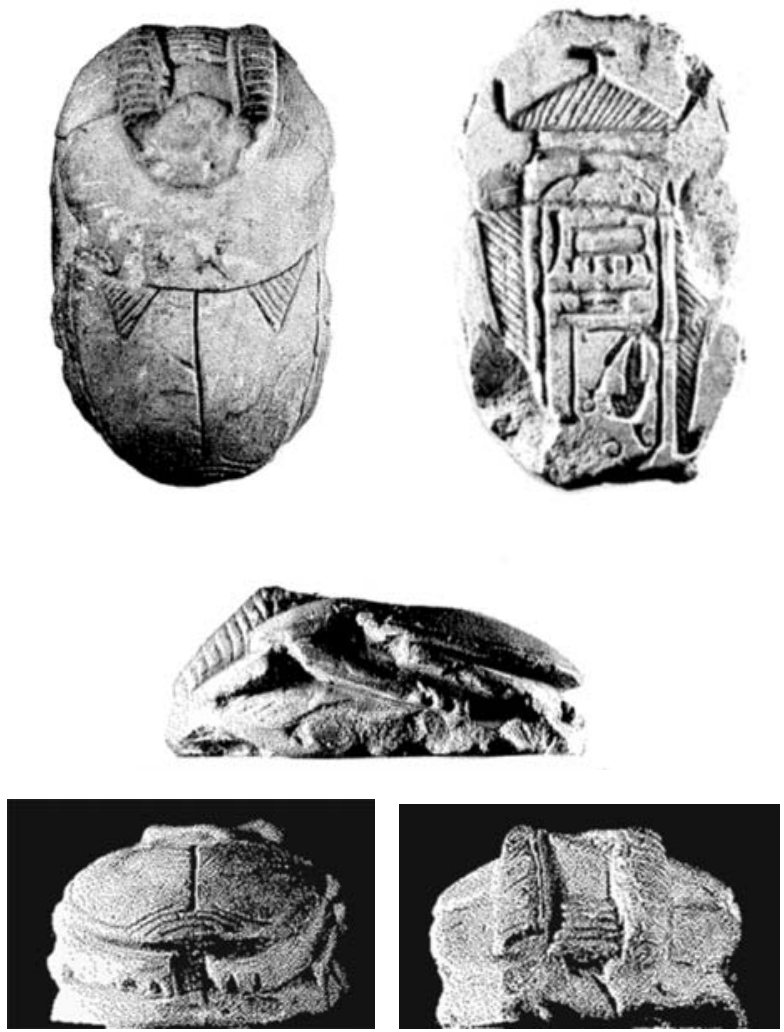

aunque el estado de conservación y las fotografías de que disponemos pueden afectar a esta apreciación.

Procedencia: Hallado en un arroyo a $1 \mathrm{~km}$ de la muralla de Murviel-lès-Montpellier, Hérault.

Lugar de conservación: Desconocido.

Conservación: Buena en apariencia, aunque falta el extremo de la cabeza.

Bibliografía: Demangel, 1935; Benoit, 1965, 68.

Anverso: Dorso con el clípeo sustituido por un cuello que habría terminado en una cabeza humana, como denotan los restos de la peluca trenzada, unida al cuerpo. El protórax, liso, se separa de los élitros mediante una línea incisa. Los élitros, finos como evidencia la vista lateral de la pieza, están resaltados por una fina línea incisa, separados por otra más profunda y decorados, en la parte superior central, por un triángulo con el vértice en el lado opuesto a la cabeza, relleno de líneas incisas diagonales orientadas hacia el exterior. La parte posterior de los élitros finaliza en unos acanalados que simulan la cola del animal.

Reverso: En la parte ventral destaca un cartucho con la inscripción wsr-m3ct-Rc mry-Ymn, que fue interpretada como nombre de coronación de Ramsés III (Demangel, 1935, 2).

Cronología: Según Benoit, correspondería a una producción romana, identificación que ya había anticipado Demangel en el primer trabajo sobre la pieza.

Iconografía: Responde al gusto romano egiptizante.

Comentario: La extrema rareza de la pieza explica que no haya sido considerada en otros trabajos sobre glíptica del sur de Francia, quizás ante la duda de que pueda tratarse de una pieza del comercio anticuario, como otras del entorno de Murviel.

\section{F-ENS1. Ensérune-1, Nissan, Hérault}

Material: Indeterminado.

Dimensiones: Indeterminado.
Perforación: Indeterminado.

Soporte: Indeterminado.

Tipo: Indeterminado.

Grabado: Indeterminado.

Procedencia: Procedente de las excavaciones anteriores a las de M. Claustres.

Lugar de conservación: Indeterminado.

Conservación: Indeterminado.

Bibliografía: Solier, 1960, 78; Benoit, 1965, 68; Padró 1983, 7, nº 01.01 .

Anverso: Indeterminado.

Reverso: Indeterminado.

Cronología: Indeterminado

Iconografía: Indeterminado

Comentario: Indeterminado

\section{F-ENS2. Ensérune-2}

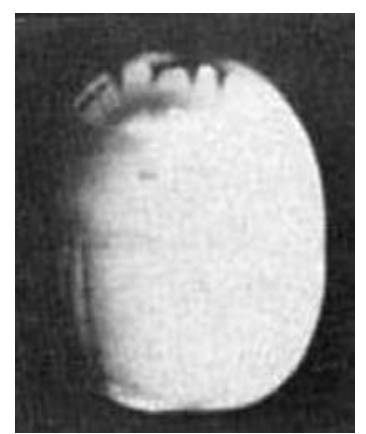

Material: Ágata blanca.

Dimensiones: Indeterminado.

Perforación: Indeterminado.

Soporte: Indeterminado.

Tipo: Esquema dorsal tipo IVb.

Grabado: Indeterminado.

Procedencia: Indeterminado.

Lugar de conservación: Teóricamente en la Société Archéologique de Béziers, después de la donación del primer propietario el M. Gondard.

Conservación: Indeterminado.

Bibliografía: Padró, 1983, 8, nº 01.02; Benoit, 1965, 68; Guiraud, 1980, 80, nota 57; 1988, 35, 185, n. 14.

Anverso: Representación de los clípeos, el tórax y los élitros están separadas por dos líneas.

Reverso: Representación de cuadrúpedo alado, posiblemente interpretable como Pegaso.

Procedencia: Corresponde a una pieza de producción etrusca, identificable dentro del llamado estilo de globolo.

Cronología: Siglo IV a.C.?

Iconografía: Indeterminado e imposible de analizar a partir de la reproducción fotográfica disponible.

Comentario: J. Padró considera la pieza de tipo etrusco (Padró, 1983, 8).

\section{F-ENS3. Ensérune-3}

Material: Pasta de vídrio verde clara.

Dimensiones: Longitud: 19,5 mm; Ancho: $15 \mathrm{~mm}$; Altura: $8 \mathrm{~mm}$.

Perforación: Indeterminado.

Soporte: Indeterminado.

Tipo: Imitación de escarabeo.

Grabado: A molde, seguramente resultado de la impronta de un escarabeo original. 


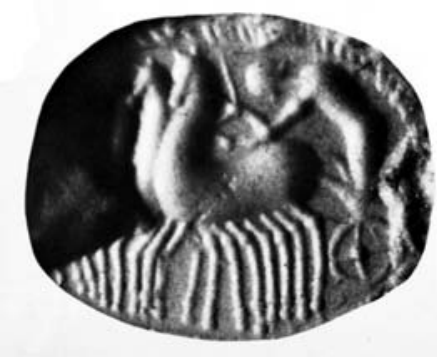

Procedencia: Indeterminado, dentro de Ensérune.

Lugar de conservación: Nissan-lèz-Ensérune, $\mathrm{N}^{\circ}$.Inv. OS812

Conservación: Buen estado de conservación de la parte ventral a pesar de una ligera fractura en la parte izquierda de la escena. El estado de la parte dorsal resulta desconocido. Bibliografía: Guiraud, 1980, 70-71, nº1; 1988, 562, Pl. XXXIX; Hansson, 2005, 54-55, nº 2.4.1.

Anverso: Indeterminado.

Reverso: Cuádriga a izquierda, donde se observa completo el cuerpo del auriga y dos de los cuatro caballo. El cuerpo de los dos caballos desaparecidos se intuye a partir de las patas, no afectadas por la fractura anteriormente comentada.

Cronología: La cronología de la pieza plantea serias dudas. La representación puede fecharse en la segunda mitad, seguramente en el último cuarto del siglo IV a.C. Por el contrario, la ausencia de paralelos en pasta de vídrio, obligan a atribuir la pieza a un momento posterior, quizás incluso a época romana, por lo que podría ser una reproducción de una pieza antigua, aunque no podemos afirmarlo.

Iconografía: La representación de carros con caballos en escarabeos etruscos es frecuente. Ejemplos próximos a este son los escarabeos 265 (con tres caballos) y 266 (con cuatro caballos) del Ashmolean Museum (Boardman y Vollenweider, 1978, 63) o el ejemplar con dos caballos BM.647 (Zazoff, 1968, 138, $\mathrm{n}^{\circ}$ 292, lám. 54). Otras 6 representaciones de cuadrigas recopila Zazoff $\left(1968, \mathrm{n}^{\circ}\right.$ 464, 470-471m 477, 481 y 485), 17 ejemplos de triga (ibídem, $\mathrm{n}^{\circ} 460,466,469,476,479,482-484,486$ y 487-494) y 24 bigas (ibídem, n ${ }^{\circ} 292,456-459,461-463,465,467-$ $468,472-475,478,480$ y $495-501)$.

Comentario: Los catálogos de Zazoff (1968) y Boardman (1975) muestran una mayoría de escarabeos etruscos de cornalina, siendo excepcionales los de sardónices, ágatas y ónices. La identificación por parte de $\mathrm{H}$. Guiraud de esta pieza como pasta vítrea imitando a un escarabeo etrusco confieren a este ejemplar una relavancia particular, pues permite pensar en una producción no etrusca, bien del entorno de Ensérune o de un punto indeterminado, quizás incluso romano.

\section{F-ILL1. L’Illette-1}

Material: Pasta azulada, vidriada.

Dimensiones: Largo: $13 \mathrm{~mm}$; Ancho: $11 \mathrm{~mm}$; Alto: $7 \mathrm{~mm}$.

Perforación: Longitudinal.

Soporte: No se conserva.

Tipo: Esquema dorsal tipo IVa.

Grabado: A molde.

Procedencia: Recuperado en 1957 durante unas labores agrícolas que dieron lugar a un pequeño sondeo con niveles poco claros y una cronología amplia.

Lugar de conservación: Museo de la Société Archéologique de Peyriac-de-Mer. No. Inv.: No documentado.
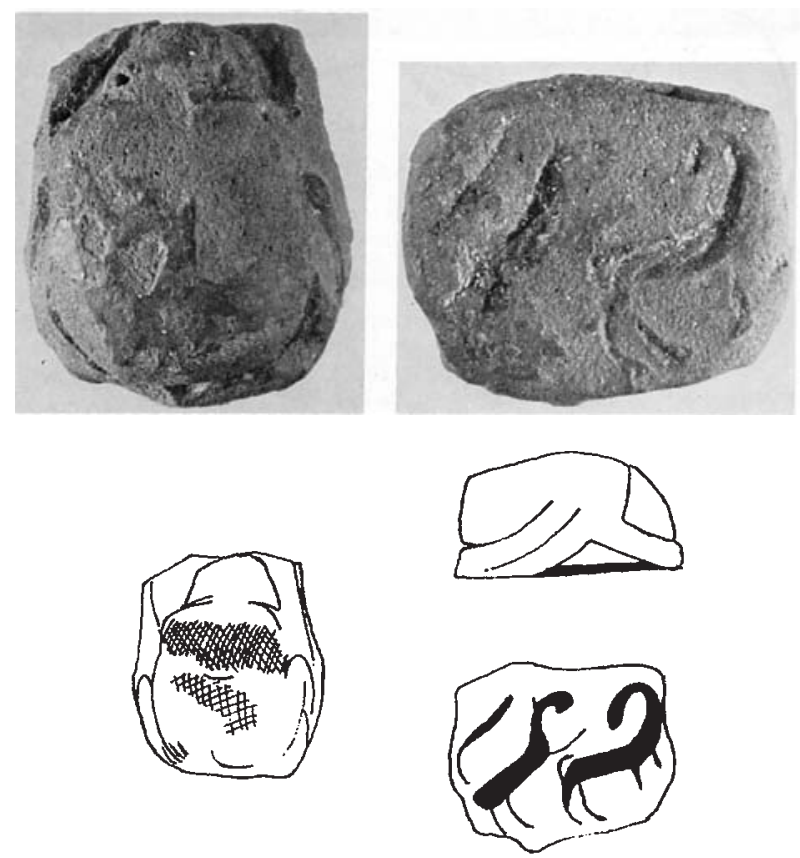

1 $2<m$

Conservación: Buen estado de conservación.

Bibliografía: Gallet de Santerre, 1962, 618; Padró, 1983, 1922, no 04.01; Benoit, 1965, 68; Gorton, 1996, 115, n 27a.

Anverso: Los élitros están bien definidos. Las patas se observan con claridad y están representadas de manera esquemática.

Reverso: Representación de un león atacando por detrás a un antílope.

Cronología: Se considera una producción naucrática de primera mitad del siglo VI a.C. El contexto no ofrece una aproximación válida para conocer el momento de su amortización.

Iconografía: La representación aparece de tipo oriental, con paralelos muy semejantes en Náucratis (Petrie, 1886, lám. XXXVII, n 140 ; Gardner, 1888, lám. XVIII.7), Cartago (Vercoutter, 1945, 131, 159 y 232, no 149-150, 258 y 623-625, lám. V, VIII y XVII), Ibiza o Ampurias (Padró, 1974b, 121; Padró, 1983, nº 07.07).

Comentario: Se trata, muy probablemente, de un producto de Náucratis, lo que deja suponer que llegado a través del comercio focense. Gorton $(1996,114)$ lo incluye en su tipo XXXIIA, caracterizado por la influencia oriental y las representaciones de caza. Pero las representaciones de caza de dicho grupo son distintas de las que ofrecen el ejemplar aquí considerado y los de Náucratis (2), Perachora (2), Heraion de Argos, Cumas (2), Cartago (2) (Gorton, 1996, 115), lo que indica un motivo propio del ámbito griego más que del púnico, frente a la propuesta de Padró (1971, 21-22) de cómo llegarían estos escarabeos a las élites languedociences.

\section{F-LAT1. Lattes-1}

Material: Jaspe verde oscuro.

Dimensiones: Largo: $13 \mathrm{~mm}$; Ancho: 9,7 mm; Alto: $7 \mathrm{~mm}$. Perforación: Longitudinal.

Soporte: No se conserva.

Tipo: Púnico, pero no se precisa el tipo de Newberry (1906) y Vercouter (1945). 


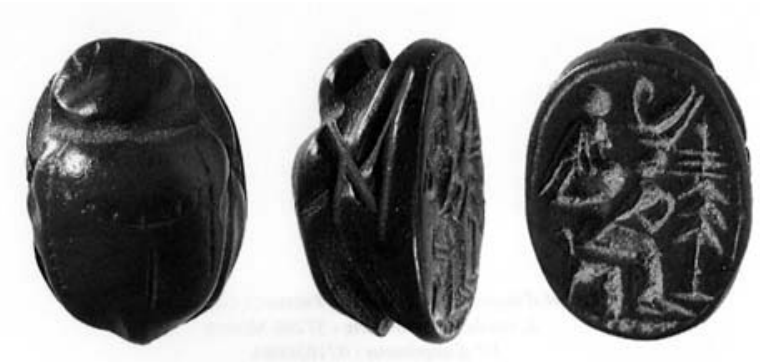

Grabado: Incisión. Según opinión de J. Padró, la técnica y estilo utilizado son de baja calidad, considerándose obra mediocre (Padró, 2010, 757).

Procedencia: Recuperado en la zona 1, nivel 53060, junto a un elevado número de importaciones áticas e ibéricas.

Lugar de conservación: Musée de Lattes. $\mathrm{N}^{\mathrm{o}}$. Inv.: No documentado.

Conservación: Ligeramente gastado por la parte dorsal, que en algunos puntos ha perdido el detalle inciso. El sello también presenta desgaste, evidente en la pérdida de la incisión de la orla, pero menos clara en la escena, que conserva todo el detalle. El aspecto general presenta bordes redondeados.

Bibliografía: Janin, 2008, 135; Padró, 2010.

Anverso: El reverso presenta un esquema dorsal con todas las partes bien delimitadas, aunque con detalle sencillo en el que únicamente los élitros aparecen separados por una doble línea y su separación del protórax se produce mediante una línea decorada con puntos. El detalle lateral representa las extremidades y morfología del cuerpo mediante líneas rectas, muy esquemáticas.

Reverso: Representación de Isis, sentada a derecha y coronada con el disco solar, amamantando a Harpókrates con la doble corona del Alto y Bajo Egipto. Al lado derecho se dispone un thymiatérion, que J. Padró ha interpretado como "autel vertical" con el signo $\mathrm{nb}$ en la parte inferior de la escena (Padró, 2010, 757).

Cronología: El contexto arqueológico se fecha entre 450425 a.C., pero la fecha de los ejemplares varía desde el siglo VI a.C. para los ejemplares cartagineses hasta el V a.C. para los ejemplares de Ibiza y Cancho Roano, aunque este tipo de escarabeo se ha fechado entre los siglos V y III a.C. (Vercoutter, 1945, 210; Conde, 2003, 237; Almagro-Gorbea et alii, 2009, 72).

Iconografía: Según J. Padró, la iconografía de Isis tuvo particular difusión en el Mediterráneo Occidental, aunque también en el Mediterráneo Central italo-sardo. El estudio del ejemplar de Cancho-Roano ya permitió observar la adaptación de la iconografía egipcia al gusto feniciopúnico, probablemente aplicado a Astart como diosa nutricia (Acquaro, 1988, 388). Conde (2003, 234 y ss.)

\section{ESTUDIO DE CONJUNTO}

El escarabeo es un talismán mágico originario de Egipto, usado desde el Imperio Antiguo (Newberry, 1906; Petrie, 1914; Bianchi, 1984). Este objeto tuvo una difusión muy amplia por todo el Mediterráneo durante el Periodo Orientalizante (Furtwängler, 1900; Vercoutter, 1945; Zazoff, 1968; Hölbl, 1979, 1986a; Padró 1983; Barnett y Mendleson, 1987; Gorton, incluye 12 paralelos de la diosa kurotrofa sobre trono, de los que sólo 2 proceden de Oriente (Almagro-Gorbea et alii, 2009, 72-73).

Los paralelos más próximos se documentan 2 en Cartago: (Vercoutter, 1945, 196, n 453, lám. XIII; Vercoutter, 1945, n' 569; Boardman, 2003, 11/104; Gubel, 1987, n ${ }^{\circ}$ 148); 1 en Útica (Vercoutter, 1945, 218, nº 569, lám. XVI; Boardman, 2003, 11/99), 4? en Kerkouan (Boardman, 2003, 11/100-11/103); 15 en Tharros: BM-ANE-133363 (Walters, 1926, no 364; Barnett y Mendelson, 1987, lám. 56c; Hölbl, 1986, n 70; Boardman, 2003, 11/78); BMANE-136023 (Boardman, 2003, 11/95; Walters, 1926, lám. 6, n 353; Gubel, 1987, nº 104; Hölbl, 1986, nº 62); Museo Civico de Como (Boardman, 2003, 11/96; Pisano, 1978, lám. 6.2; Gubel, 1987, n 107, Hölbl, 1986, nº 63); Boardman, 2003, 11/83 (Hölbl, 1986, n64, lám. 152; Gubel, 1987, n 138); Cagliari 19749 (Boardman, 2003, 11/84); Cagliari 38542 (Boardman, 2003, 11/85; Gubel, 1987, $\mathrm{n}^{\circ}$ 108; Hölbl, 1986, $\mathrm{n}^{\circ}$ 66bis); Cagliari 349451 (Boardman, 2003, 11/86; Gubel, 1987, n 136; Hölbl, 1986, no 58 y 60; Acquaro, 1980, 45, lám. 7.2; Garbini, 1993, lám. 8.1); Boardman, 2003, 11/87 (Furtwängler, 1900, lám. XV.7); Boarman, 2003,11/88 (Hölbl, 1986, nº 61); Cagliari 362 (Bordman, 2003, 11/89; Gubel, 1987, $n^{\circ}$ 105; Hölbl, 1986, no 59); Cagliari 357 (Boardman, 2003, 11/90; Gubel, 1987, n 106; Hölbl, 1986, n 69); Cagliari 357bis (Boardman, 2003, 11/91); Cagliari 363 (Boardman, 2003, 11/93; Gubel, 1987, n 137; Hölbl, 1986, n 66); Cagliari 380 (Boardman, 2003, 11/94); Colección Chessa (Boardman, 2003, 11/98; Hölbl, 1986, $\mathrm{n}^{\circ}$ 68); Caralis-Tumba 941 (Boardman, 2003, 11/97; Gubel, 1987, n 135; Hölbl, 1986, n 67); Túnez, en el Metropolitan Museum, New York (Richter, 1956, n 190; Boardman, 2003, 11/106); 5 de Ibiza (Fernández y Padró, 1982, 31-41 y 73, no 5; Boardman, 1984, 42-43, n' $52-$ 55, lám. IX-X; Gubel, 1987, nº 94-96 y 134); 1, Cancho Roano (Maluquer, 1981, 350, fig. 54; Celestino, 2001, 64; Conde, 2003, 231-237; Garcia Martínez, 2001, 148-149, $\mathrm{n}^{\circ}$ 29.01, lám. II. X-XI; Almagro et alii, 2009, 72-73); 1, Ashkelon 14745 (Boardman, 2003, 11/107); 1, Jerusalem IAA-32649 (Boardman, 2003, 11/108; Gubel, 1987, $\mathrm{n}^{\circ}$ 79); 1, de procedencia indeterminada (Boardman, 2003, 11/112 y 11/113; Gubel, 1987, n 139; Zwierlein-Diehl, 1973, 17, IX.213); 1, de la colección De Clerq en la Biliothèque Nationale, Paris $n^{\circ} 2734$, quizás el ejemplar más próximo al de Lattes por su trazo sencillo y estructura (De Ridder, 1911, lám. 18; Boardman, 2003, 11/110; Gubel, 1987, nº 71).

Comentario: Fue publicado inicialmente como un escarabeo egipcio sobre piedra dura (Janin 2008), pero el estudio pormenorizado de J. Padró $(2010,758)$ lo identificó como un escarabeo púnico.
1996; Boardman, 2003; etc.), difundido especialmente gracias a los fenicios y su valor mágico perduró hasta el final de la Antigüedad. Los escarabeos son uno de los elementos más característicos de los asentamientos fenicios y púnicos de Occidente desde el siglo VIII al IV a.C., en Cartago (Vercoutter, 1945), Cerdeña (Matthiae Scandone, 1975; Hölbl, 1986a; Barnett y 


\begin{tabular}{|c|c|c|c|c|c|c|c|c|}
\hline $\mathrm{N}^{\mathrm{o}}$ & Procedencia & Fecha & Material & Tipo & Iconografía & Taller & Contexto & Fecha id. \\
\hline 1 & SOL1. Solivella-1 & $594-525$ & $\mathrm{~F}$ & IV & león & Náucratis & tumba & $550-525$ \\
\hline 2 & TB1. Torrelló Boverot-1 & $400-300$ & $\mathrm{CO}$ & VI & guerrero & Etruria & tumba & $400-300$ \\
\hline 3 & PM1 Puig Misericordia-1 & ¿? & ¿? & ¿? & ¿? & ¿? & hábitat & $550-300 ?$ \\
\hline 4 & PN1. Puig de la Nao-1 & $500-400$ & $\mathrm{Ag}$ & anillo & persona+árbol & púnico & hábitat & $500-400$ \\
\hline 5 & TM1. Tossal Moro-1 & $600-500$ & $\mathrm{~F}$ & cowroi. & grifo & Egipto & hábitat & $575-525$ \\
\hline 6 & MM1. Mas Mussols-1 & $625-550$ & $\mathrm{~F}$ & II & esfinge & Náucratis & tumba $X$ & 550 \\
\hline 7 & MM2. Mas Mussols-2 & $589-570$ & $\mathrm{~F}$ & $?$ & epígrafe & Náucratis? & tumba X & 550 \\
\hline 8 & MM3. Mas Mussols-3 & $600-550$ & F & VI & león+loto & Náucratis & tumba X & 550 \\
\hline 9 & MM4. Mas Mussols-4 & $600-550$ & F & $\mathrm{V}$ & esfinge & Náucratis & tumba $\mathrm{X}$ & 550 \\
\hline 10 & MM5. Mas Mussols-5 & $600-550$ & F & botón & círculos & Náucratis & tumba X & 550 \\
\hline 11 & TOR1. Tortosa-1 & $663-588$ & F & ¿? & Sobek+escarb. & Egipto & ¿? & i? \\
\hline 12 & CC1. Can Canyís-1 & $663-588$ & F & VI & antílope & Náucratis & tumba & $575-550$ \\
\hline 13 & CC2. Can Canyís-2 & $600-550$ & $\mathrm{~F}$ & VI & antílope & Náucratis & tumba & $575-550$ \\
\hline 14 & CC3. Can Canyís-3 & $595-588$ & $\mathrm{~F}$ & VI & epígrafe & Náucratis & tumba & $575-550$ \\
\hline 15 & CC4. Can Canyís-4 & $595-588$ & $\mathrm{~F}$ & VI & león & Náucratis & tumba & $575-550$ \\
\hline 16 & CC5. Can Canyís-5 & $600-550$ & F & VI & cabra & Náucratis & tumba & $575-550$ \\
\hline 17 & CC6. Can Canyís-6 & $600-550$ & $\mathrm{~F}$ & VI & ¿? & Náucratis & tumba & $575-550$ \\
\hline 18 & CC7. Can Canyís-7 & $663-588$ & $\mathrm{~F}$ & VI & epígrafe & Náucratis & tumba & $575-550$ \\
\hline 19 & CC8. Can Canyís-8 & $600-550$ & $\mathrm{~F}$ & VI & león & Náucratis & tumba & $575-550$ \\
\hline 20 & CC9. Can Canyís-9 & $600-550$ & $\mathrm{~F}$ & VI & epígrafe & Náucratis & tumba & $575-550$ \\
\hline 21 & CC10. Can Canyís-10 & $625-588$ & $\mathrm{~F}$ & botón & esfinge & Náucratis & tumba & $575-550$ \\
\hline 22 & CC11. Can Canyís-11 & $600-550$ & $\mathrm{~F}$ & botón & esfinge & Náucratis & tumba & $575-550$ \\
\hline 23 & CC12. Can Canyís-12 & 595-589 & $\mathrm{F}$ & escde. & epígrafe & Náucratis & tumba & $575-550$ \\
\hline 24 & CC13. Can Canyís-13 & $600-550$ & $\mathrm{~F}$ & botón & i? & Náucratis & tumba & $575-550$ \\
\hline 25 & CC14. Can Canyís-14 & $600-550$ & $\mathrm{~F}$ & botón & león & Náucratis & tumba & $575-550$ \\
\hline 26 & CC15. Can Canyís-15 & $600-550$ & $\mathrm{~F}$ & botón & ¿? & Náucratis & tumba & $575-550$ \\
\hline 27 & CC16. Can Canyís-16 & $600-550$ & $\mathrm{~F}$ & escde. & ¿? & Náucratis & tumba & $575-550$ \\
\hline 28 & CC17. Can Canyís-17 & $600-550$ & $\mathrm{~F}$ & escde. & ¿? & Náucratis & tumba & $575-550$ \\
\hline 29 & CC18. Can Canyís-18 & $600-550$ & F & escde. & ¿? & Náucratis & tumba & $575-550$ \\
\hline 30 & LP1. La Pedrera-1 & $200-100$ & $\mathrm{CO}$ & & grifo & romano & tumba? & $200-1$ \\
\hline 31 & LP2. La Pedrera-2 & $100-1$ & Sardónic. & ¿? & guerrero & romano & tumba? & $200-1$ \\
\hline 32 & LP3. La Pedrera-3 & $100-300 \mathrm{JC}$ & Sardónic. & & halcón & romano & tumba? & $100-300 \mathrm{JC}$ \\
\hline 33 & EC1. Castejón-1 & $625-575$ & $\mathrm{~F}$ & VI & Ptah+ureo & Egipto & tumba & $575-350$ \\
\hline 34 & EC2. Castejón-2 & $600-500$ & EST & V & esfinge & Egipto? & tumba & $575-350$ \\
\hline 35 & EC3. Castejón-3 & $663-550$ & EST & IV & esfinge & Egipto? & tumba & $575-350$ \\
\hline 36 & TDP1. Turó dels 2 Pins- 1 & $600-500 ?$ & $\mathrm{M}$ & botón & ¿? & Egipto & tumba & $250-180$ \\
\hline 37 & AMP1. Ampurias-1 & $600-500$ & $\mathrm{~F}$ & cor. & liso & Egipto & ¿? & $600-500 ?$ \\
\hline 38 & AMP2. Ampurias-2 & c. 400 & $\mathrm{~J}$ & IIIa & jinete & púnico? & habitat & $400-300$ \\
\hline 39 & AMP3. Ampurias 3 & $425-375$ & $\mathrm{~J}$ & V & Isis + Horus & púnico & ¿? & ¿? \\
\hline 40 & AMP4. Ampurias-4 & $400-300$ & $\mathrm{~J}$ & $\mathrm{~V}$ & guerrero & púnico & ¿? & ¿? \\
\hline 41 & AMP5. Ampurias-5 & $400-300$ & Ónice & IVc & guerrero & etrusco? & ¿? & ¿? \\
\hline 42 & AMP6. Ampurias 6 & $325-275$ & $\mathrm{CO}$ & III & grifo & etrusco & ¿? & i? \\
\hline 43 & AMP7. Ampurias 7 & $700-500$ & $\mathrm{~F}$ & IV óV & antílope+león & fenicio & ¿? & post. 550 \\
\hline 44 & AMP8. Ampurias 8 & c. 500 & $\mathrm{~F}$ & I & Yam & fenicio & ¿? & ¿? \\
\hline 45 & AMP9. Ampurias-9 & $400-300 ?$ & $\mathrm{CO}$ & ¿? & escorpión & púnico? & ¿? & ¿? \\
\hline 46 & AMP10. Ampurias 10 & $500-475$ & F & III ó IV & liso & fenicio & ¿? & ¿? \\
\hline 47 & AMP11. Ampurias 11 & $525-510$ & $\mathrm{CO}$ & VI & dios + león & griego? & tumba & $400-350$ \\
\hline 48 & AMP12. Ampurias-12 & $600-550$ & $\mathrm{~F}$ & VI & grypomachia & Náucratis & tumba & 550 \\
\hline 49 & AMP13. Ampurias-13 & $550-475$ & $\mathrm{~J}$ & ¿? & egipcio? & fenicio? & ¿? & ¿? \\
\hline 50 & AMP14. Ampurias-14 & $500-300 ?$ & $\mathrm{~J}$ & ¿? & egipcio? & púnico? & ¿? & ¿? \\
\hline 51 & AMP15. Ampurias-15 & $500-300 ?$ & $\mathrm{~F}$ & ¿? & egipcio? & púnico? & ¿? & ¿? \\
\hline 52 & AMP16. Ampurias-16 & $600-525$ & $\mathrm{~J}$ & escde. & cabeza negro & Náucratis? & ¿? & ¿? \\
\hline 53 & AMP17. Victor Català-1 & $650-550$ & F ó EST & II & Horus-Halcón & Egipto & tumba & ¿? \\
\hline 54 & AMP18. Victor Català-2 & $625-525$ & F ó EST & II & esfinge & Egipto & tumba & ¿? \\
\hline 55 & AMP19. MEV & $650-500$ & Ámbar & ¿? & i? & fenicio? & tumba? & ¿? \\
\hline 56 & AMP20. & c. 300 & Sardónic. & & guerrero & etrusco & habitat & ¿? \\
\hline 57 & AMP21. & $100-1$ & $\mathrm{CO}$ & & grifo? & romano & habitat & ¿? \\
\hline 58 & AMP22. & $400-300 ?$ & Cuarzo & & liso & etrusco? & ¿? & ¿? \\
\hline 59 & AMP23. Col. Casellas.1 & $450-350 ?$ & $\mathrm{CO}$ & & Heracles & etrusco? & ¿? & i? \\
\hline 60 & PER1. Peralada-1 & $600-525$ & F? & ¿? & ¿? & Egipto? & tumba & $575-450$ \\
\hline
\end{tabular}




\begin{tabular}{|c|c|c|c|c|c|c|c|c|}
\hline 61 & RO1. Rosas-1 & $350-300$ & Ámbar & III & Bes & púnico & hábitat & $325-275$ \\
\hline 62 & VIL1. Vilabertrán-1 & $300-400 \mathrm{JC}$ & $\mathrm{J}$ & & inscripción & griego & & c. $1300 \mathrm{JC}$ \\
\hline 63 & F-MON1. Montlaurès-1 & $400-300$ & $\mathrm{~J}$ & ¿? & ave + gato? & púnico? & hábitat & ¿? \\
\hline 64 & F-MON2. Montlaurès-2 & $500-300 ?$ & $\mathrm{CO}$ & escde. & cara de frente & púnico & hábitat & ¿? \\
\hline 65 & F-MON3. Montlaurès-3 & $400-300$ & $\mathrm{CO}$ & VI & Heracles? & etrusco & hábitat & ¿? \\
\hline 66 & F-MON4. Montlaurès-4 & $600-525$ & $\mathrm{~F}$ & IVa & Jeroglífico & Náucratis & tumba & $600-500$ \\
\hline 67 & F-MUR1. Murviel-1 & ¿? & Caliza & ¿? & ¿? & romano? & ¿? & ¿? \\
\hline 68 & F-ENS1. Ensérune-1 & ¿? & ¿? & ¿? & ¿? & i? & hábitat & $500-300$ \\
\hline 69 & F-ENS2. Ensérune-2 & 400-300? & Ágata & $\mathrm{IVb}$ & Pegaso & etrusco & hábitat & $500-300$ \\
\hline 70 & F-ENS3. Ensérune-3 & $325-300$ & $\mathrm{~F}$ & ¿? & cuádriga & ¿? & hábitat & $500-300$ \\
\hline 71 & F-ILL1. L'Illette-1 & $600-550$ & $\mathrm{~F}$ & IVa & león + antílope & Náucratis & hábitat & ¿? \\
\hline 72 & F-LAT1. Lattes-1 & c. 450 & $\mathrm{~J}$ & & Isis + Horus & púnico & hábitat & $450-425$ \\
\hline
\end{tabular}

Figura 1: Cuadro resumen de los escarabeos del Nordeste de Hispania y del Sur de la Galia.

Mendleson, 1987; Gorton, 1996; etc.), Ibiza (Fernández y Padró, 1982; Boardman, 1984) y en Hispania (Gamer-Wallert, 1978; Padró, 1980 a 1995; López de la Orden, 1990; García Martínez, 2001), pero también aparecen con relativa frecuencia en ambientes etruscos, griegos e indígenas, por lo que constituyen uno de los elementos más representativos del proceso de interacción y aculturación, además de aparecer siempre asociados a las élites sociales que controlaban dichas relaciones.

El actual proyecto de recopilar un Corpus de Escarabeos de Hispania como parte del Corpus des Antiquités Pheniciennes et Puniques que patrocina la Union Académique International tiene la finalidad de actualizar las recopilaciones hasta ahora realizadas de objetos egipcios y egiptizante de la Península Ibérica (Gamer-Wallert, 1978; Padró, 1980 a 1995; García Martínez, 2001), cuya calidad y utilidad deben ser resaltadas. Sin embargo, su principal objetivo es, a partir de esos estudios, analizar los escarabeos por áreas culturales, para comprender mejor su contexto arqueológico y cultural y, al mismo tiempo, para aprovechar la información que ofrecen estos objetos sobre los procesos de contacto y aculturación en el plano socio-ideológico de fenicios, y también de los griegos, con las poblaciones indígenas con las que estaban en contacto.

Para lograr dicho objetivo se ha planteado llevar a cabo distintos estudios regionales, a fin de contrastar semejanzas y diferencias. En estos análisis, la zona del Noreste de la Península Ibérica, entendida en sentido amplio, con su irradiación por el Valle del Ebro y hacia el Sur de Francia, ofrece gran interés, pues corresponde a áreas ocupadas por gentes que proceden de un substrato de los Campos de Urnas muy distinto del que caracteriza otras áreas de la Hispania prerromana (Almagro-Gorbea y Ruiz Zapatero, 1993), cuyo análisis evidencia la existencia de distintas influencias. Esta

\begin{tabular}{|c|c|c|c|c|c|c|c|c|}
\hline $\mathbf{N}^{\circ}$ & Procedencia & Fecha & Material & Tipo & Iconografía & Taller & Contexto & Fecha id. \\
\hline 43 & AMP7. Ampurias 7 & $700-500$ & $\mathrm{~F}$ & IV óV & antílope+león & fenicio & ¿? & post. 550 \\
\hline 11 & TOR1. Tortosa-1 & $663-588$ & $\mathrm{~F}$ & ¿? & Sobek+escarb. & Egipto & ¿? & ¿? \\
\hline 12 & CC1. Can Canyís-1 & $663-588$ & $\mathrm{~F}$ & VI & antílope & Náucratis & tumba & $575-550$ \\
\hline 18 & CC7. Can Canyís-7 & $663-588$ & $\mathrm{~F}$ & VI & epígrafe & Náucratis & tumba & $575-550$ \\
\hline 34 & EC2. Castejón-3 & $663-570$ & EST & $\mathrm{V}$ & jeroglífico & Egipto? & tumba & c. 500 \\
\hline 35 & EC3. Castejón-2 & $663-550$ & EST & IV & esfinge & Egipto? & tumba & $500-475$ \\
\hline 53 & AMP17. Victor Català-1 & $650-550$ & F ó EST & II & Horus-Halcón & Egipto & tumba & ¿? \\
\hline 55 & AMP19. MEV & $650-500$ & Ámbar & ¿? & ¿? & fenicio? & tumba? & ¿? \\
\hline 21 & CC10. Can Canyís-10 & $625-588$ & $F$ & botón & esfinge & Náucratis & tumba & $575-550$ \\
\hline 33 & EC1. Castejón-1 & $600-575$ & $\mathrm{~F}$ & VI & Ptah+ureo & Egipto & tumba & $500-475$ \\
\hline 6 & MM1. Mas Mussols-1 & $625-550$ & $\mathrm{~F}$ & II & esfinge & Náucratis & tumba $\mathrm{X}$ & 550 \\
\hline 54 & AMP18. Victor Català-2 & $625-525$ & F ó EST & II & esfinge & Egipto & tumba & ¿? \\
\hline 22 & CC11. Can Canyís-11 & $600-550$ & $\mathrm{~F}$ & botón & esfinge & Náucratis & tumba & $575-550$ \\
\hline 24 & CC13. Can Canyís-13 & $600-550$ & $\mathrm{~F}$ & botón & ¿? & Náucratis & tumba & $575-550$ \\
\hline 25 & CC14. Can Canyís-14 & $600-550$ & $\mathrm{~F}$ & botón & león & Náucratis & tumba & $575-550$ \\
\hline 26 & CC15. Can Canyís-15 & $600-550$ & $\mathrm{~F}$ & botón & ¿? & Náucratis & tumba & $575-550$ \\
\hline 27 & CC16. Can Canyís-16 & $600-550$ & $\mathrm{~F}$ & escde. & ¿? & Náucratis & tumba & $575-550$ \\
\hline 28 & CC17. Can Canyís-17 & $600-550$ & $\mathrm{~F}$ & escde. & ¿? & Náucratis & tumba & $575-550$ \\
\hline 29 & CC18. Can Canyís-18 & $600-550$ & $\mathrm{~F}$ & escde. & ¿? & Náucratis & tumba & $575-550$ \\
\hline
\end{tabular}




\begin{tabular}{|c|c|c|c|c|c|c|c|c|}
\hline 8 & MM3. Mas Mussols-3 & $600-550$ & $\mathrm{~F}$ & VI & león+loto & Náucratis & tumba $\mathrm{X}$ & 550 \\
\hline 9 & MM4. Mas Mussols-4 & $600-550$ & $\mathrm{~F}$ & $\mathrm{~V}$ & esfinge & Náucratis & tumba X & 550 \\
\hline 10 & MM5. Mas Mussols-5 & $600-550$ & $\mathrm{~F}$ & botón & círculos & Náucratis & tumba X & 550 \\
\hline 13 & CC2. Can Canyís-2 & $600-550$ & $\mathrm{~F}$ & VI & antílope & Náucratis & tumba & $575-550$ \\
\hline 16 & CC5. Can Canyís-5 & $600-550$ & $\mathrm{~F}$ & VI & cabra & Náucratis & tumba & $575-550$ \\
\hline 17 & CC6. Can Canyís-6 & $600-550$ & $\mathrm{~F}$ & VI & ¿? & Náucratis & tumba & $575-550$ \\
\hline 19 & CC8. Can Canyís-8 & $600-550$ & $\mathrm{~F}$ & VI & león & Náucratis & tumba & $575-550$ \\
\hline 20 & CC9. Can Canyís-9 & $600-550$ & $\mathrm{~F}$ & VI & epígrafe & Náucratis & tumba & $575-550$ \\
\hline 48 & AMP12. Ampurias-12 & $600-550$ & $\mathrm{~F}$ & VI & grypomachia & Náucratis & tumba & 550 \\
\hline 71 & F-ILL1. L'Illette-1 & $600-550$ & $\mathrm{~F}$ & IVa & león + antílope & Náucratis & hábitat & ¿? \\
\hline 52 & AMP16. Ampurias-16 & $600-525$ & $\mathrm{~J}$ & escde. & cabeza negro & Náucratis? & ¿? & ¿? \\
\hline 60 & PER1. Peralada-1 & $600-525$ & $\mathrm{~F}$ ? & ¿? & ¿? & Egipto? & tumba & $575-450$ \\
\hline 66 & F-MON4. Montlaurès-4 & $600-525$ & $\mathrm{~F}$ & IVa & jeroglífico & Náucratis & tumba & $600-500$ \\
\hline 36 & TDP1. Turó dels 2 Pins & $600-500 ?$ & $M$ & botón & ¿? & Egipto & tumba & $250-180$ \\
\hline 5 & TM1. Tossal Moro-1 & $600-500$ & $\mathrm{~F}$ & cowroi. & grifo & Egipto & hábitat & $575-525$ \\
\hline 37 & AMP1. Ampurias-1 & $600-500$ & $\mathrm{~F}$ & cor. & liso & Egipto & ¿? & $600-500 ?$ \\
\hline 23 & CC12. Can Canyís-12 & $595-589$ & $\mathrm{~F}$ & escde. & epígrafe & Náucratis & tumba & $575-550$ \\
\hline 14 & CC3. Can Canyís-3 & $595-588$ & $\mathrm{~F}$ & VI & epígrafe & Náucratis & tumba & $575-550$ \\
\hline 15 & CC4. Can Canyís-4 & $595-588$ & $\mathrm{~F}$ & VI & león & Náucratis & tumba & $575-550$ \\
\hline 1 & SOL1. Solivella-1 & $594-525$ & $\mathrm{~F}$ & IV & león & Náucratis & tumba & $550-525$ \\
\hline 7 & MM2. Mas Mussols-2 & $589-570$ & $\mathrm{~F}$ & $?$ & epígrafe & Náucratis? & tumba X & 550 \\
\hline 49 & AMP13. Ampurias-13 & $550-475$ & $\mathrm{~J}$ & ¿? & egipcio? & fenicio? & ¿? & ¿? \\
\hline 47 & AMP11. Ampurias 11 & $525-510$ & $\mathrm{CO}$ & VI & dios + león & griego? & tumba & $400-350$ \\
\hline 44 & AMP8. Ampurias 8 & c. 500 & $\mathrm{~F}$ & $\mathrm{I}$ & Yam & fenicio & ¿? & ¿? \\
\hline 46 & AMP10. Ampurias 10 & $500-475$ & $\mathrm{~F}$ & III ó IV & liso & fenicio & ¿? & ¿? \\
\hline 4 & PN1. Puig de la Nao-1 & $500-400$ & $\mathrm{Ag}$ & anillo & persona+árbol & púnico & hábitat & $500-400$ \\
\hline 50 & AMP14. Ampurias-14 & $500-300 ?$ & $\mathrm{~J}$ & ¿? & egipcio? & púnico? & ¿? & ¿? \\
\hline 51 & AMP15. Ampurias-15 & $500-300 ?$ & $\mathrm{~F}$ & ¿? & egipcio? & púnico? & ¿? & ¿? \\
\hline 64 & F-MON2. Montlaurès-2 & $500-300 ?$ & $\mathrm{CO}$ & escde. & cara de frente & púnico & hábitat & ¿? \\
\hline 72 & F-LAT1. Lattes-1 & c. 450 & $\mathrm{~J}$ & & Isis + Horus & púnico & hábitat & $450-425$ \\
\hline 59 & AMP23. Col. Casellas.1 & $450-350 ?$ & $\mathrm{CO}$ & & Heracles & etrusco? & ¿? & ¿? \\
\hline 38 & AMP3. Ampurias 3 & $425-375$ & $\mathrm{~J}$ & $\mathrm{~V}$ & Isis + Horus & púnico & ¿? & ¿? \\
\hline 38 & AMP2. Ampurias-2 & c. 400 & $\mathrm{~J}$ & IIIa & jinete & púnico? & habitat & $400-300$ \\
\hline 45 & AMP9. Ampurias-9 & $400-300 ?$ & $\mathrm{CO}$ & ¿? & escorpión & púnico? & ¿? & ¿? \\
\hline 58 & AMP22. & $400-300 ?$ & Cuarzo & & liso & etrusco? & ¿? & ¿? \\
\hline 69 & F-ENS2. Ensérune-2 & $400-300 ?$ & Ágata & $\mathrm{IVb}$ & Pegaso & etrusco & hábitat & $500-300$ \\
\hline 2 & TB1. Torrelló Boverot-1 & $400-300$ & $\mathrm{CO}$ & $\mathrm{VI}$ & guerrero & Etruria & tumba & $400-300$ \\
\hline 40 & AMP4. Ampurias-4 & $400-300$ & $\mathrm{~J}$ & $\mathrm{~V}$ & guerrero & púnico & ¿? & ¿? \\
\hline 41 & AMP5. Ampurias-5 & $400-300$ & Ónice & IVc & guerrero & etrusco? & ¿? & ¿? \\
\hline 63 & F-MON1. Montlaurès-1 & $400-300$ & $\mathrm{~J}$ & ¿? & ave + gato? & púnico? & hábitat & ¿? \\
\hline 65 & F-MON3. Montlaurès-3 & $400-300$ & $\mathrm{CO}$ & $\mathrm{VI}$ & Heracles? & etrusco & hábitat & i? \\
\hline 61 & R01. Rosas-1 & $350-300$ & Ámbar & III & Bes & púnico & hábitat & $325-275$ \\
\hline 70 & F-ENS3. Ensérune-3 & $325-300$ & $\mathrm{~F}$ & ¿? & cuádriga & ¿? & hábitat & $500-300$ \\
\hline 42 & AMP6. Ampurias 6 & $325-275$ & $\mathrm{CO}$ & III & grifo & etrusco & ¿? & ¿? \\
\hline 56 & AMP20. & c. 300 & Sardónic. & & guerrero & etrusco & habitat & ¿? \\
\hline 30 & LP1. La Pedrera-1 & $200-100$ & $\mathrm{CO}$ & & grifo & romano & tumba? & $200-1$ \\
\hline 31 & LP2. La Pedrera-2 & $100-1$ & Sardónic. & ¿? & guerrero & romano & tumba? & $200-1$ \\
\hline 57 & AMP21. & $100-1$ & $\mathrm{CO}$ & & grifo? & romano & habitat & ¿? \\
\hline 32 & LP3. La Pedrera-3 & $100-300 \mathrm{JC}$ & Sardónic. & & halcón & romano & tumba? & $100-300 \mathrm{JC}$ \\
\hline 62 & VIL1. Vilabertrán-1 & $300-400 \mathrm{JC}$ & $\mathrm{J}$ & & inscripción & griego & & c. $1300 \mathrm{JC}$ \\
\hline 3 & \begin{tabular}{|l|} 
PM1 Puig Misericordia \\
\end{tabular} & ¿? & ¿? & ¿? & ¿? & ¿? & hábitat & $550-300 ?$ \\
\hline 67 & F-MUR1. Murviel-1 & ¿? & Caliza & ¿? & ¿? & romano? & ¿? & ¿? \\
\hline 68 & F-ENS1. Ensérune-1 & ¿? & ¿? & ¿? & ¿? & ¿? & hábitat & $500-300$ \\
\hline
\end{tabular}

Figura 2: Cuadro de los escarabeos del Nordeste de Hispania y del Sur de la Galia ordenados por fechas. 
zona del Mediterráneo, en contacto con múltiples culturas, mantuvo su propia personalidad, lo que ilustra de manera particular los múltiples usos de los escarabeos más allá de su uso "tradicional", como sello y elemento de autorrepresentación (Torelli, 2002, 102), además de como elemento renovador del imaginario colectivo y de la iconografía, como aquí se evidencia.

En esta amplia y variada región se conocen actualmente 72 escarabeos (vid. supra nota 1) (Fig. 1), repertorio que ha sido estudiado de manera exhaustiva y casi exclusiva por J. Padró ${ }^{2}$, a quien se hace referencia de forma continua. Se trata de uno de los conjuntos más numerosos de Hispania, que puede compararse y en muchos casos supera las cantidades aparecidas en otras áreas de la Península Ibérica, con la excepción de Ibiza, cuyas necrópolis han proporcionado el conjunto más destacable, que supera ampliamente los 100 ejemplares. Otros conjuntos importantes son los cerca de 40 de la cueva-santuario de Gorham's Cave, en Gibraltar, y las piezas cada día más numerosas de las necrópolis y de la ciudad de Gades, cuyo número, incluidas las crétulas, supera los 30 ejemplares, a los que habría que sumar, por una parte, los del área tartésica de las provincias de Huelva, Cádiz, Sevilla, que constituye su hinterland directo, y, por otra, las 19 piezas de las colonias y factorías de la Costa del Sol y los más de 15 ejemplares situados en el hinterland de éstas, en la Andalucía centro-oriental, junto a los que hay que incluir los más de 20 escarabeos del Sur de Portugal y los más de 25 de Extremadura. Otro importante conjunto los forman los escarabeos del Sureste, cuyo creciente número ya supera los 50 ejemplares, entre los que destacan 12 piezas, entre escarabeos y entalles púnicos, de Villaricos. Este contexto regional explica el interés de los escarabeos del Nordeste de Hispania, pues ofrecen características propias, que reflejan corrientes comerciales y culturales distintas y, también, como ya hemos avanzado, un substrato cultural diferente.

\section{TIPOLOGÍA Y CRONOLOGÍA}

El conjunto de 72 escarabeos del Nordeste de Hispania y su hinterland ofrece una tipología no muy variada (Cuadro 1), formada por 39 escarabeos, de los que 1 es de corazón, AMP1, aunque su procedencia no sea del todo segura, 6 escaraboides, 7 'botones' o

2. Padró 1971; 1971-1972; 1974a; 1974b; 1976-1978; 1980; 1982-1983; 1983; 1985. Destacan también distintos trabajos sobre piezas concretas, normalmente en los estudios monográficos de los yacimientos donde aparecieron: J. Maluquer (1962) en Tossal del Moro de Pinyeres; D. Fletcher (1965) en la necrópolis de la Solivella; M. Almagro-Basch (1953, 1955) en las necrópolis de Ampurias, etc. También resulta muy útil la recopilación de I. Gamer-Wallert (1978) en su amplio trabajo sobre los materiales egipcios de la Península Ibérica. sellos y 1 cowroid, además de 1 sello de plata, PN1, inspirado en un escarabeo púnico (Fig. 1), 5 piezas de época romana y 12 piezas cuyas características no es posible conocer por haberse perdido y sólo conservarse de ellos la noticia, en ocasiones muy incierta, de su aparición.

La tipología de estos escarabeos (Newberry, 1906, 70 y ss.; Vercoutter, 1945, 10 y 72 y ss.) permite señalar que 1 es del tipo I; 3 del II, 4 del III, 7 del IV, 4 del V y 15 del VI. A este respecto, es interesante que el tipo I se fecha c. 500 a.C.; el II, del 650/625 al 550/525 a.C.; el III, del 500 al 275 a.C.; el IV, del 650 al 525 a.C., aunque las variantes IVb y IVc se fechan ya $c$. 400-300 a.C.; el V ofrece un amplio margen, 600-375 a.C.; y los del VI, los más numerosos, se fechan de $c$. 650 al 500 a.C., aunque dos ejemplares de cornalina del tipo VI, TB1 y MON3, ofrecen una cronología mucho más baja, c. 400-300 a.C. (Fig. 2).

Los escarabeos constituyen importaciones, que cabe considerar como exotica, que presentan una evolución tanto cuantitativa como cualitativa. Resultan muy raros en el arco noroeste del Mediterráneo Occidental al aparecer a fines del siglo VII o, más probablemente, ya iniciado el VI a.C., pero a partir de $c$. 575 a.C. se evidencia una creciente "divulgación" de su uso, aunque sin dejar nunca de ser piezas de circulación "social" limitada, ya que resulta evidente que, desde su aparición, constituían objetos sumamente preciados, aunque se constata un aumento significativo en su uso desde el siglo VI a.C., ya al final del período orientalizante, hasta su progresivo desuso en los siglos siguientes.

Respecto al material con el que han sido fabricados, la mayoría de las piezas, 36, son de pasta o fayenza originariamente vidriada, pero 2 de los escarabeos no es seguro si son de pasta o de esteatita. También son numerosos los fabricados con piedras semipreciosas: 10 de jaspe o diaspro verde, 10 de cornalina, 2 de ámbar, 2 quizás de esteatita, 1 de ágata, 1 de ónice, 1 de marfil y 3 ó 4 de sardónice. La cronología de los distintos materiales permite observar que los ejemplares de pasta o fayenza se datan c. 650-500 a.C., aunque 32 de las 35 piezas identificadas corresponden al periodo 575-525 a.C. Los 2 escarabeos de pasta o de esteatita se fechan 650-525 a.C.; el botón de marfil debe fecharse en el siglo VI a.C.; los 9 escarabeos de jaspe o diaspro verde son de c. 525-300 a.C., fecha que coincide con los de cornalina, aunque una de estas piezas es ya de época romana. Los 2 escarabeos de ámbar parecen fecharse hacia el siglo V o IV a.C., aunque uno de ellos, AMP19, pudiera ser algo anterior; los de ágata y ónice también se fechan en el siglo IV a.C, así como los dos de sardónice etruscos. Por último, los de sardónice de La Pedrera de Tarragona son de época romana.

La morfología de las piezas y el material empleado evidencian una clara secuencia evolutiva, a pesar de la escasez de datos sobre su contexto arqueológico, que podría precisar la fecha de cada uno de los escarabeos. En este sentido, es muy ilustrativo que la 
clara secuencia evolutiva que refleja la cronología de las piezas (vid. infra) evidencia, más que modas, las corrientes comerciales e ideológicas ocurridas durante el tiempo en que estuvieron en uso estos objetos, que en el Nordeste de Hispania queda precisado en unos tres siglos, desde poco después del 600 a.C. hasta el 300 a.C., como tope máximo (Figs. 2 y 3).

A lo largo de dicho periodo se diferencian varias fases en el uso de los escarabeos y piezas relacionadas. La primera se extiende aproximadamente desde c. 600/575 a.C. hasta fines del siglo VI a.C. Algunas piezas relacionadas con Psamético I (663-609 a.C.) pudieran ser algo anteriores y remontarse a la segunda mitad del siglo VII a.C., como las CC1, CC7, EC3, AMP17 y TOR1. Sin embargo, tanto en Can Canyís como en Ampurias y en El Castillo de Castejón esas piezas aparecen asociadas a otras datadas con seguridad en la primera mitad del siglo VI a.C., por lo que esta cronología parece la más segura para la comercialización y fabricación de todas ellas, ya que forman parte de conjuntos cerrados de composición muy homogénea. En consecuencia, a la primera mitad del siglo VI a.C. corresponden 40 piezas, que suponen más del 55\% del total. Aunque esta cifra está claramente deformada por los conjuntos de Mas de Mussols y de Can Canyís, en principio debe considerarse como un hecho evidente y de indudable interés, pues aun teniendo en cuenta dicho factor, es evidente que, a partir de c. 550 a.C., se observa una evidente disminución de los escarabeos, que probablemente deben relacionarse con la crisis de Focea c. 540 a.C. y también con el cierre de la factoría de Náucratis en el último cuarto del siglo VI a.C. Por ello no debe extrañar que los escarabeos disminuyan en esta segunda fase a tan sólo 3 ó 4 piezas, que apenas representan un $4 \%$ del total.

Los esquemas dorsales de los escarabeos de Can Canyís corresponden todos al tipo VI, según la tipología propuesta Newberry (1906, 70 y ss.) y Vercoutter (1945, 10 y 73), a excepción de los ejemplares CC10 y CC15, identificados como 'botones' o Discoid Button-Seals. La cronología del importante conjunto de Can Canyís varía según los autores. Padró (1983) propuso una datación en la primera mitad del siglo VI a.C., pero D. Bea (1996) propone una cronología más concreta, en el primer cuarto del siglo VI a.C. Sea como sea, la datación no puede ser en ningún caso anterior a los años de reinado de los faraones identificados en los sellos (Amenhotep III, Psamético I, Psamético II y Apris). La diacronía aparente entre algunas piezas, como la de Amenhotep III (1386-1350 a.C.), se explica por la frecuente copia de este nombre en época saíta (Padró, 1983, 18). Más problemática es la de Psamético I (663-609 a.C.), que debe interpretarse como una perduración hasta época de Psamético II (594-588 a.C.) y de Apris (589-570 a.C.), reinados que dan una segura fecha ad quem a estos productos y probablemente post quem para su llegada a Hispania. La fecha del escarabeo de la necrópolis de La Solivella, que apareció en la tumba 6 (Fletcher,

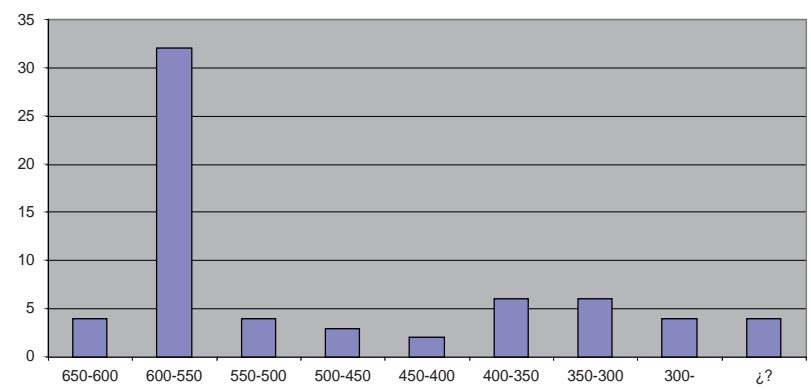

Figura 3: Histograma de la distribución de los escarabeos a lo largo del tiempo.

1965; Padró, 1974a; 1980; 1983, 108 y ss.), ha sido discutida por su atribución a Psamético I, aunque J. Padró lo fechó en la primera mitad del siglo VI a.C. por analogía con las piezas de Can Canyís y del Mas de Mussols (Padró, 1983, 110), pues, además, el tipo de inscripción, como en el ejemplar de Can Canyís, corresponde a una variante tardía. De todas formas, el ajuar de la tumba 6 en que apareció el escarabeo se sitúa claramente en el último cuarto del siglo VI a.C. Por otro lado, la mayoría de los escarabeos de Ampurias proceden de los hallazgos de sus necrópolis (Padró, 1974; 1980), pero las tumbas con escarabeos asociados del siglo VI a.C. se reduce a un solo caso, ya que la mayoría de los escarabeos recuperados carecen de contexto.

Sobre esta fase inicial de los escarabeos del Noreste de la Península Ibérica cabe hacer algunas observaciones. La primera es que el repertorio se compone principalmente de piezas de producción egipcia, pero en su inmensa mayoría naucrática, esto es, probablemente jonia o incluso focense, pues los 28 ejemplares identificados como tales representan algo más del $75 \%$ del total de ese periodo, seguidas de lejos por 8 piezas de origen egipcio en sentido estricto, que representan otro $21 \%$, mientras que las de origen fenicio parecen ser sólo 2, lo que supone tal sólo un $5 \%$, hecho que puede considerarse significativo, como también lo es la inexistencia de piezas griegas y etruscas ${ }^{3}$ (Fig. 4).

Lamentablemente, la mayoría de los escarabeos, escaraboides y piezas relacionadas halladas en el Noreste de Hispania no han aparecido en excavaciones

3. En fases posteriores sí que se identifican ejemplares fenicios, griegos y etruscos, pero la fase I la forman exclusivamente ejemplares amortizados en siglo VI a.C. La existencia de algunos escarabeos de producción etrusca ya fue señalada por J. Padró (1983), a los que se suma el ejemplar posteriormente publicado del Torrelló del Boverot (Clausell, 2002-2003). Además, el reciente catálogo de escarabeos fenicios realizado por J. Boardman (2003) ha identificado como fenicias algunas piezas previamente consideradas egipcias, aunque el ejemplar de la Colección de Clerq (Boardman, 2003, $\mathrm{n}^{\mathrm{o}}$ 26.34) no procede de Tortosa en España (Boardman, 2003, 141), sino de Tarso (Boardman, 2003, 81; J. Boardman, comunicación personal a R. Graells). 


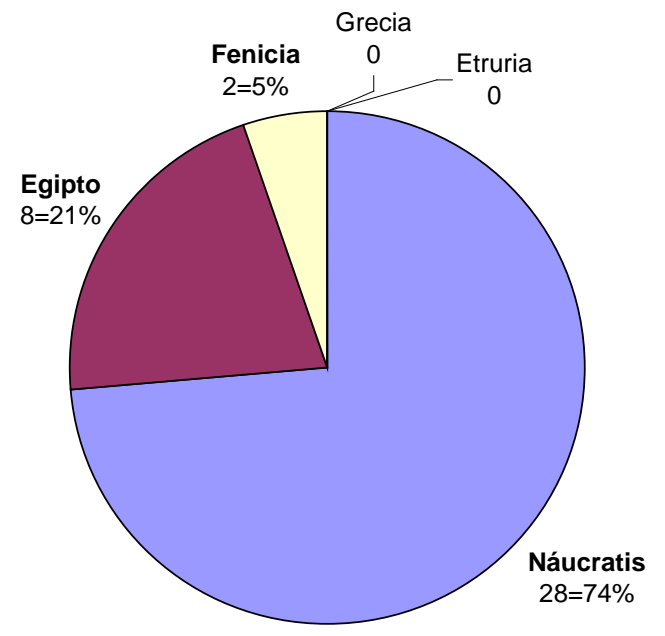

Figura 4: Proporciones de los escarabeos del siglo VI a.C. en el arco noroeste del Mediterráneo.

científicas, como ocurre con la totalidad de los ejemplares de Can Canyís y uno de los escarabeos de la necrópolis del Mas de Mussols, lo que dificulta conocer su contexto arqueológico original, ya que únicamente han sido hallados en excavaciones los escarabeos de la tumba Muralla NE 11 y de la inhumación Martí 15 en las necrópolis de Ampurias, el de la tumba 6 de la Solivella y otros tres ejemplares de la necrópolis de El Castillo, en Castejón, Navarra.

Sin embargo, a esos escarabeos hay que sumar los conjuntos cerrados de piezas cuyas circunstancias de hallazgo permiten concluir que proceden de la misma tumba. Este es el caso de los conjuntos de escarabeos y piezas relacionadas de las necrópolis de Mas de Mussols y de Can Canyís (Vilaseca et alii, 1963, 73; Padró, 1971, 129; Ferrer, 1991, 415; Mancebo y Ferrer, 1992, 316; Graells, 2010, 55), cuya tipología confirma que constituían sendos depósitos cerrados, tal como ratifican otros hallazgos de la Hispania meridional, donde algunas tumbas contenían numerosos amuletos de tipo egipcio y fenicio que formarían collares ${ }^{4}$.

Otro hecho a destacar en los escarabeos del Nordeste de la Península Ibérica, por su significado aun mayor, es que nunca han aparecido asociados a elementos fenicios (Graells, 2010, 55), ni siquiera el numeroso conjunto de escarabeos y piezas similares de la necrópolis de Can Canyís, ya que ésta no ha proporcionado ningún elemento que permita alzar su

4. Por ejemplo, la tumba 5 de la necrópolis de Les Casetes, con un colgante en pasta vítrea de tipo "máscara demoníaca", cuentas de pasta vítrea oculadas y 4 amuletos de esteatita egipcios (García Gandía, 2005, 351, fig. 12; 2009, 47-49, fig. 23), la tumba 5 de la zona B de la necrópolis de Puente de Noy, con 22 amuletos egipcios en hueso, tres en fayenza, un escarabeo de cornalina, 6 cuentas de collar de pasta vítrea, tres de piedra, uno de fayenza y otro de cornalina (Molina, Ruiz y Huertas, 1982, 45-49, fig. 18 y 19), al margen, como en la tumba anterior, de otros elementos. cronología más allá del 575 a.C. y lo mismo cabe decir de El Castillo de Castejón, en Navarra. En consecuencia, los escarabeos y piezas relacionadas del Nordeste son claramente posteriores al horizonte de las importaciones fenicias en Cataluña de fines del siglo VII a.C. (Graells, 2010, 196 y 228-234, fig. 132), por lo que deben considerarse contemporáneos del primer horizonte focense, que cabe relacionar con la fundación de Emporion, c. 575 a.C. Este dato desvincula los escarabeos del comercio fenicio y, en cambio, los relaciona con el comercio griego focense, directo o vía Etruria, como indicaría el peso del comercio griego entre la colonia naucrática y Gravisca, entre otros enclaves, lo que ayuda a comprender la abundancia de piezas procedentes de Náucratis, la famosa factoría griega en Egipto, de la que formaba parte Focea (Herod. II, 178). El mismo hecho se constata en la tumba $X$ del Mas de Mussols, datada con seguridad en torno al 550 a.C. (Graells, 2010, 193-198), y en la necrópolis de la Muralla NE de Ampurias, que ya corresponde a la segunda mitad del siglo VI a.C. Por lo tanto, se trata siempre de contextos posteriores al segundo cuarto del siglo VI a.C., hecho que confirma su estrecha relación con el comercio focense e impiden relacionar estos objetos con el horizonte colonial fenicio.

En este sentido, hay que señalar que estos escarabeos producidos en Náucratis, que parecen haber sido distribuidos por los focenses, alcanzan también Andalucía (García Martínez, 2001, 177), como la necrópolis de Jardín, en Málaga (Schubart y MaassLindemann, 2007, lám. 9,4.16), Gibraltar (Culican, 1972, 114, fig. 3, lám. XX,4), Cádiz (Perdigones et alii, 1990, fig. 38,21 y lám. 13-14) y la zona atlántica de Portugal (García Martínez, 2001, no 36.01, 02, 03 y 37.01), por lo que ofrecen especial interés para precisar un horizonte de importaciones focenses, datado c. 575-540 a.C., que se extiende desde Massalia a Tartessos, como evidencian los hallazgos de Huelva (Cabrera, 1989). Con este horizonte se relacionan los aryballoi de Náucratis y las copas jonias de tipo B2 que aparecen por todas las costas de Hispania, así como los broches de cinturón jonio-tartesios (Parzinger y Sanz 1986) y alguna selecta importación, como el Centauro de Rollos en Albacete (Olmos, 1983) o la placa de marfil de El Turuñuelo, en Badajoz (Jiménez Ávila y Ortega, 2004, fig. 54). Este horizonte merece ser analizado con atención en el futuro, pues intuimos que se asocia a los primeros mercenarios 'celtas' profocenses que actuaron en los conflictos en Tartessos y que parecen documentarse en las sepulturas de guerrero con lanzas de larga punta y regatón (Lorrio, 2008), asociadas a grebas (Farnié y Quesada, 2005), a cuchillos de dorso curvo (Lorrio, 2008a) y a broches de cinturón de garfios jonio-tartesios (Parzinger y Sanz, 1986), que aparecen desde el Suroeste, por ejemplo en Alcácer do Sal y Medellín (Lorrio, 2008), en la tumba Les Casetes 20, de Villajoyosa, Alicante, en el Sureste (García Gandía, 2005, fig. 2; 2009, 78-82, fig. 87) y también en el Nordeste, en Mas de Mussols (Maluquer, 
1987, fig. 3-4), Can Canyís (Vilaseca et alii, 1963) y otras necrópolis catalanas (Graells, 2010), elementos que penetraron profundamente hacia el interior, como evidencia la necrópolis de El Castillo de Castejón, en Navarra, asociados a escarabeos atribuibles a dicho horizonte (Faro et alii, 2003; Unzu y Faro, 2006).

De este modo se comprende el significado histórico de estos exotica, pues indican cómo los focenses, apoyados en una pequeña factoria como Emporion, prácticamente carente de fuerza demográfica, gracias a esos exotica asociados al vino y la vajilla para beber y a cinturones y telas, supieron estructurar un inteligente sistema clientelar de mercenarios que les permitieron intervenir en Tartessos y desequilibrar el círculo fenicio de Gadir y establecer un sistema colonial desde el Sureste a Massalia, basado en el protectorado o 'indirect rule', ya que se apoyaría sobre estas élites guerreras por ellos promocionadas. Estos hechos y los documentos arqueológicos que parecen constatarlos ayudan a comprender los cambios ideológicos introducidos desde el mundo colonial en el ámbito indígena, para cuyo conocimiento es esencial la información que ofrecen los escarabeos, ya que, a través de estas élites guerreras indígenas debió arraigar el sistema gentilicio clientelar, cuya ideología heroica se basaba en el Héroe Fundador, probablemente tras asimilar mitos griegos (Almagro-Gorbea y Lorrio, 2011), tal como parece evidenciar el escarabeo naucrático de la tumba 11 de la Necrópolis NE de Ampurias, AMP12. Este sistema ideológico pasó a constituir el fundamento del poder de toda la Hispania indoeuropea, incluidas amplias áreas del mundo ibérico, frente a la tradición de monarquías sacras de las áreas meridionales (Almagro-Gorbea, 1996).

También resulta de evidente interés comparar los escarabeos del Nordeste de Hispania con los hallazgos de Portugal (Almagro-Gorbea y Torres, 2009), Extremadura (Almagro-Gorbea et alii, 2009) y Andalucía (Gamer-Wallert, 1978; Padró, 1985; García Martínez, 2001). Resulta evidente que en el Noreste de Hispania no aparecen escarabeos fenicios arcaicos, salvo 1 o 2 piezas (AMP7 y, probablemente, AMP8), además, relativamente tardíos, hecho que debe relacionarse con la introducción de este elemento por los focenses, seguramente junto a sus abundantes importaciones de piezas de Náucratis, tal como se ha señalado.

Este panorama cambia radicalmente a partir de fines del siglo VI e inicios del siglo V a.C., fase en la que sólo se han hallado 2 ó 3 escarabeos en Ampurias. Uno es el escarabeo arcaico de cornalina AMP11, datado c. 530-510 a.C., de singular interés por su iconografía oriental de estilo helénico, lo que deja incierto su taller, quizás griego oriental o, más bien, fenicio, por lo que constituye una pieza muy especial en el conjunto de los escarabeos de Hispania, aunque evidencia un largo uso hasta su amortización en la inhumación Martí 15, posterior al 400 a.C. A su vez, el escarabeo AMP8, por el contrario, es fenicio y puede fecharse en la segunda mitad del siglo VI o inicios del
V a.C., como probablemente el AMP7, que pudiera ser incluso anterior.

Tras esta fase de transición, a partir del siglo $\mathrm{V}$ a.C., se constata un evidente cambio en las corrientes comerciales de los escarabeos y en sus centros productores, con un creciente predominio de los productos genéricamente denominados 'púnicos', entre los que cabe destacar las producciones de talleres sardos, en su mayoría todavía muy mal identificados. Dichos productos debían llegar en gran medida a través de Ibiza, cuyos contactos con Ampurias son bien conocidos. Sin embargo, destaca la variedad de materias primas en que están elaborados, como 8 de jaspe, seguramente púnicos (AMP2-AMP4, AMP13, AMP14, AMP16, LAT1, MON1) y 9 de cornalina, de ellos 1 greco-fenicio? (AMP11), 2 púnicos (AMP9 y MON2) y 6 etruscos (AMP6, AMP21, AMP23, TB1, MON3 y LP1) a los que se suma uno en sardónice (AMP20). Siempre de producción etrusca podemos añadir un ejemplar de ágata (ENS2), otro de ónice (AMP5) y uno más en pasta de vidrio imitando un escarabeo (ENS3). Más problemático resulta un ejemplar de ámbar (RO1) que parece ser feno-púnico, más que etrusco, y, para terminar, otro de ámbar (AMP19), de procedencia indeterminada, que quizás sea una imitación itálica.

Los diferentes estilos que ofrecen reflejan multitud de talleres, entre los que faltan los griegos, pero a partir del siglo IV a.C. destaca la presencia de escarabeos de talleres etruscos (AMP5, AMP6, AMP20, AMP21, TB1, MON3, ENS2, ENS3, BO1), procedencia que predomina proporcionalmente en la Galia mediterránea y que resulta muy escasa en el resto de Hispania, pues, además del ejemplar de El Boverot, BO1, en Castellón, apenas cabe señalar algún otro en colonias púnicas como Ibiza (M. J. Almagro Gorbea, 1986, 266), Almuñécar (Molina, 1986, 211) y Cádiz (Nicolini, 1990, $\mathrm{n}^{\circ}$ 128), todos ellos del siglo IV a.C. En su conjunto, este periodo indica la creciente apertura del Mediterráneo Occidental a distintas corrientes comerciales y culturales que representaban el desarrollo del helenismo y que culminan con su total integración en el imperio romano a partir del siglo II a.C., con ejemplos como el escarabeo AMP10, si su centro de producción estuviera situado en el Mar Negro.

Un último hecho a señalar es la falta de información sobre el contexto arqueológico de la mayoría de ejemplares, que impide asociar el uso de escarabeos a hombres o a mujeres, así como conocer el tiempo de uso de las piezas. La única excepción son los escarabeos de Castejón EC1 y EC2, que proceden de una tumba masculina principesca, seguramente regia, por ir asociados a armas, arreos de caballo y al más rico ajuar con elementos de banquete. También cabe señalar que los conjuntos del Mas de Mussols y de Can Canyís indican que fue breve el lapso de tiempo transcurrido entre la fabricación del escarabeo y su amortización en una tumba, hecho que cabe hacer extensivo a la incineración de la Muralla NE 11, igualmente atribuible a un personaje de la élite indígena de 


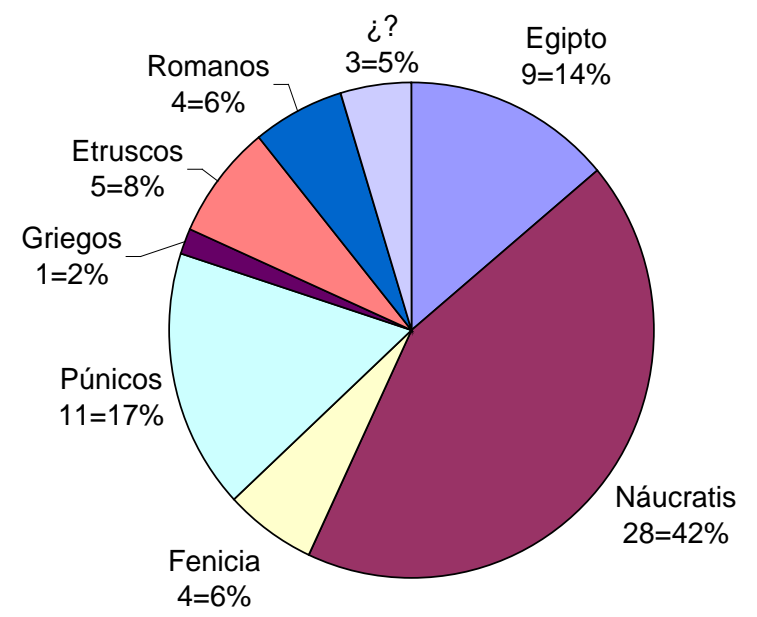

Figura 5: Procedencia de los escarabeos hallados en el arco noroeste del Mediterráneo.

los Campos de Urnas de la Edad del Hierro, como el escarabeo aparecido en la sepultura infantil de Montlaurés-4. Igualmente, el escarabeo de la tumba 6 de la necrópolis de La Solivella, datada c. 525-500 a.C. por su ajuar, puede considerarse prácticamente contemporáneo, pues se data c. 594-525 a.C. Lo mismo cabría decir del escarabeo de Lattes LAT1 hallado en un nivel de c. 450-425 a.C., contemporáneo, por no decir anterior, a la fecha que ofrece por motivos estilísticos. Por el contrario, una excepción la constituyen los escarabeos de El Castillo de Castejón, datados c. 600-575 a.C. y enterrados en tumbas de c. 500-475 a.C. y el mismo fenómeno ofrece la inhumación Martí 15, datada después del 400 a.C., pues en ella apareció un escarabeo fechado c. 530-510 a.C., lo que supone un lapso de casi 4 generaciones, aunque este hecho no debe sorprender, ya que resulta relativamente atestiguado en este tipo de objetos, como se constata en Cancho Roano (Maluquer de Motes, 1981; AlmagroGorbea et alii, 2009) y en la necrópolis de Villaricos (Almagro Gorbea y Almagro-Gorbea, 2009).

Se puede concluir que el momento de eclosión en el uso de los escarabeos corresponde a un grupo de piezas producidas en sincronía cronológica y espacial, principalmente en Náucratis (Fig. 4). La particular concentración de aegyptiaca, sincrónicos y tipológicamente afines, en Mas de Mussols y Can Canyís, con una amortización coetánea, permite algunas reflexiones que, lamentablemente, deben quedar como hipótesis, ya que no se pueden confirmar por falta de datos de excavación. Por un lado, la presencia de piezas de las mismas series en los dos conjuntos puede interpretarse como resultado de una misma importación y de una posterior redistribución desde un contexto ibérico. Por otro lado, la escasa distancia entre el momento de producción de los escarabeos $\left(2^{\circ}\right.$ cuarto del siglo VI a.C.) y el de su amortización (c. 550 a.C), permite proponer que no serían piezas tesaurizadas, sino que, probablemente, serían amortizadas por su primer propietario. De poder confirmar esta segunda propuesta, los escarabeos y su eventual selección iconográfica se erigen en transmisores de una ideología destinada a las élites y en instructores de una iconografía coetánea, que, aunque culturalmente pueda parecer lejana, los ejemplos conocidos evidencian una intencionada selección de los temas. El mejor ejemplo en el escarabeo de la Muralla NE de Ampurias, que ofrece una escena de grypomachia que indicaría la identificación de su posesor con un antepasado heroico.

En conclusión, la tipología de las piezas halladas en el Noreste de Hispania es acorde con su cronología, pues ofrecen una clara evolución, aunque limitada en el tiempo, lo que explica la ausencia de ejemplares fenicios antiguos o de tipo oriental y el claro predominio inicial de piezas de Náucratis, que parecen indicar un control, casi absoluto, del comercio y de los contactos por parte de los focenses. Más sorprende la relativa escasez en periodos posteriores de piezas de estilo helenizante, en su mayoría constituidas por producciones púnicas, quizás de talleres sardos, y por algunos escarabeos etruscos. Dentro de este cuadro, destaca casi en todas las épocas la diversidad de talleres de procedencia, naucráticos, egipcios, feniciopúnicos y etruscos, éstos mucho más frecuentes que en el resto de Hispania, mientras que, por el contrario, casi resultan ausentes los ejemplares de origen griego (Fig. 5). El conjunto denota una gran diversidad de corrientes comerciales con las debían llegar hasta las lejanas tierras del Noroeste del Mediterráneo estos preciados objetos, que reflejan los cambios de gusto y, sobre todo, los cambios ideológicos ocurridos a partir de mediados del I milenio a.C. en el Mediterráneo.

\section{DISPERSIÓN}

Resulta también interesante realizar un breve análisis de la dispersión geográfica. La primera evidencia que se desprende es que en el arco noroeste del Mediterráneo los escarabeos ofrecen una dispersión sumamente costera (Fig. 6A), que contrasta con la de otras regiones de Hispania, incluido el Sureste (Gamer-Wallert, 1978; Padró, 1980-1985; Almagro-Gorbea y Torres, 2009; Almagro-Gorbea et alii, 2009). La única excepción son los escarabeos recientemente aparecidos en El Castillo de Castejón, Navarra (Faro et alii, 2003; Unzu y Faro, 2006), que evidencian la profunda penetración de estos productos por el Valle del Ebro. Por el contrario, los ejemplares de Lattes, Murviel, Ensérune, Montlaurés o Batea no alteran el señalado aspecto costero de la dispersión.

El análisis cuantitativo resulta menos revelador (Fig. 6B). El mayor conjunto, por lógica, aparece en la colonia focense de Emporion, aunque cabe destacar el conjunto situado en la desembocadura del Ebro, en las costas de Tarragona y Castellón, concentración que ayuda a comprender la sorprendente penetración de estos productos hasta la zona de Navarra. Un tercer foco, ya menor, puede señalarse en el Hérault, 

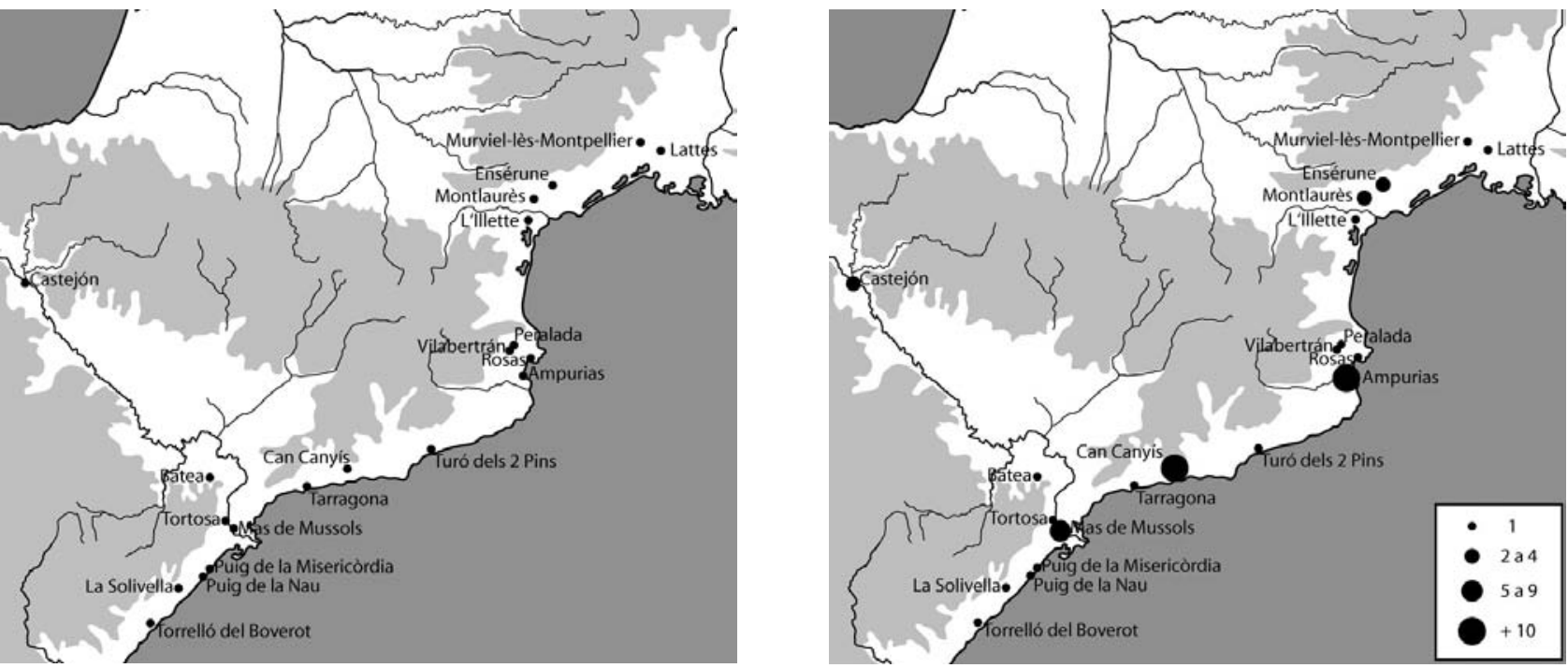

Figura 6: A, Área analizada con los yacimientos que han ofrecido escarabeos. B, Número de escarabeos aparecidos en cada yacimiento.

ampliable hasta la zona de Lattes, en el que destaca una relativamente alta proporción de escarabeos etruscos, así como de púnicos, que probablemente indican relaciones con Ibiza, quizás a través del comercio ampuritano, más que con Cerdeña, aunque esta posibilidad deberá ser analizada en el futuro.

Más difícil es poder señalar otras características, dado el limitado tamaño de la muestra, como la dispersión de los distintos talleres (Fig. 7A) y su dispersión geográfica según su cronología (Fig. 7B). En todo caso, escarabeos de origen egipcio al norte de los Pirineos cuentan con un único ejemplar, mientras que los escarabeos etruscos proporcionalmente predominan en la Galia meridional, aunque están ampliamente representados en Ampurias, pero ya no en otros yacimientos, con la excepción de El Torrelló del Boverot. Sin poder ser concluyentes, estas apreciaciones parecen reflejar la dirección contrapuesta del comercio fenicio y del etrusco, sin excluir que unos y otros, pero en especial los escarabeos fenicios, llegaran a través del comercio focense (vid. supra).

Los productos de Náucratis se concentran en las costas de Tarragona y de la desembocadura del Ebro, además de aparecer en Ampurias y un ejemplar en L'Illete. Su relación con el comercio focense ya ha sido señalada (vid. supra), por lo que reflejan una precisa dirección de los intereses comerciales en el siglo VI a.C., c. 575-525 a.C. Por último, es interesante señalar que los escasos escarabeos de talleres fenicios se concentran en Ampurias, mientras que los púnicos aparecen ampliamente difundidos desde el sur de al Galia hasta las costas de Castellón y más allá, pues alcanzan plenamente el Sureste, si bien ofrecen una clara concentración en Ampurias, que refleja las
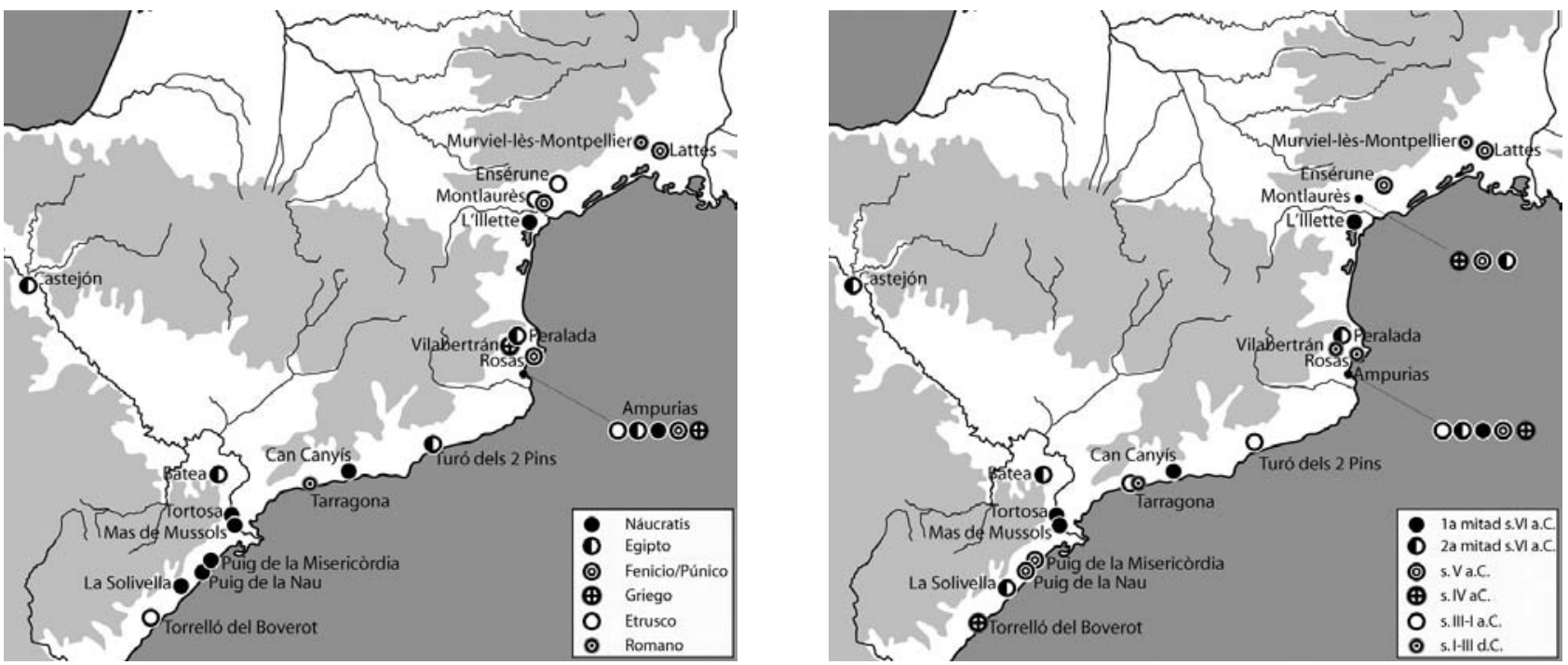

Figura 7: A, Dispersión de los escarabeos según su origen. B, Dispersión de los escarabeos según su fecha. 
intensas relaciones comerciales entre Emporion y Ebusus, relaciones cuyo auge se produce ya en fechas más avanzadas.

En conclusión, el análisis de la dispersión geográfica refleja en su conjunto pequeñas variaciones regionales de indudable interés, aunque el cuadro resulta relativamente unitario, en especial si se compara con otras regiones de Hispania, ya que las evidentes diferencias señaladas se deben interpretar, sobre todo, como reflejo de la complejidad de las corrientes comerciales que incidían sobre las distintas regiones del arco noroeste del Mediterráneo.

\section{ICONOGRAFÍA}

Un especial interés ofrece analizar la iconografía de los 72 escarabeos y sellos hallados en el Noreste de Hispania y en la Galia mediterránea, una vez superadas las reticencias sobre la capacidad de comprensión de la iconografía y del significado de estos objetos, tema muy debatido en los últimos años, al considerarse de manera tópica que la iconografía y los objetos traídos por los fenicios tenían un valor exclusivamente de adorno y, en todo caso, "mágico", sin que sus adquirientes fueran capaces de comprender su significado religioso e ideológico. Estas posturas escépticas contrastaban con los resultados de las investigaciones en Oriente (Keel y Ühlinger, 1998) y también con los alcanzados en la Península Ibérica (Almagro-Gorbea, 2002; 2005; Almagro-Gorbea y Torres, 2009; Almagro-Gorbea et alii, 2009), que demuestran la perfecta comprensión del significado de los símbolos e imágenes del repertorio orientalizante tanto por los fenicios como por las poblaciones indígenas que los adquirían, ya que constituía un verdadero lenguaje gráfico.

Ante la práctica ausencia de fuentes directas y el muy escaso desarrollo de la iconografía antes del periodo helenístico, probablemente son los escarabeos la mejor documentación existente sobre los mitos y creencias que circulaban por el ámbito colonial y, en especial, entre las élites indígenas que los adquirían para su uso, por lo que ofrecen pistas insustituibles para conocer el sistema ideológico y su evolución a lo largo del tiempo.

De los 72 escarabeos del NE de Hispania sólo se han podido analizar 56 ejemplares (Fig. 1), pues 3 carecen de sello (AMP1, AMP10, AMP22) y otros son ilegibles por su mal estado de conservación y otras causas (CC6, CC13-17, AMP19) o por haberse perdido el ejemplar sin estar bien documentado (AMP1315, ENS1, PM1).

A pesar de este número relativamente escaso de piezas, los escarabeos actualmente conocidos permiten identificar más de 77 figuras, que cabe agrupar en 25 motivos iconográficos distintos (Fig. 8), algunos de ellos repetidos, lo que constituye un repertorio bastante reducido si se compara con los de Extremadura (Almagro-Gorbea et alii, 2009) e, incluso, con los de
Portugal (Almagro-Gorbea y Torres, 2009). La causa estriba en que muchos escarabeos ofrecen escenas de cierta complejidad, con más de un motivo simple, en especial los escarabeos con sello epigráfico, cuyos jeroglíficos se pueden contabilizar por la iconografía epigráfica de los signos que ofrecen, como el ureo, el disco solar o el halcón, además de como evidencia del valor mágico que la escritura ofrecía en sí misma. Junto a estos símbolos, también se debe valorar el simbolismo del propio escarabeo (Bianchi, 1984), como podría ser el caso en las dos piezas que carecen de sello (AMP1, AMP10), aunque la primera pudiera proceder del mercado de antigüedades. Por el contrario, no se ha contabilizado el signo $n b$, situado en el exergo de muchos escarabeos egipcios y feno-púnicos, aunque es evidente que pudo interpretarse como referencia a que lo que había encima tenía carácter divino y sacro.

Los escarabeos con jeroglíficos son 8, 5 de ellos con nombres de faraones, lo que supone una alta proporción, pues supera el $75 \%$ de los que tienen jeroglíficos: dos a nombre de Amenhotep III (CC7 y MON4, Nb-M', 't-R', neb-maat-Ra); 2 de Psamético I (CC3 y MM2, Psmtk), otro con el nombre de Horus de Psamético II (CC12, Hr-mn-R') ) y otro con el praenomen de Psamético I o el nomen de Apris (EC3, *W3h-íb$\left.R^{`}\right)$. Todos son nombres de faraones que aparecen con frecuencia en escarabeos de Baja Época. Además, un escarabeo ofrece la leyenda "El señor es Amón-Ra" (CC9, Imn-r'nb) y dos ejemplares ofrecen posibles criptogramas de Amón (EC1 y AMP17).

Los escarabeos cuyo sello ofrece representaciones de divinidades egipcias constituyen otro apartado de interés, junto a las que cabe señalar los seres y símbolos míticos, muchas veces identificados en los símbolos epigráficos de los jeroglíficos. Las representaciones de divinidades egipcias son muy escasas, pues se reducen a 1 de Ptah (EC1), 1 de Sobek (TOR1) y a 2 de Isis con Horus (LAT1, AMP3). Las divinidades egipcias son bien conocidas en el panteón feno-púnico y eran populares en otras áreas de Hispania (AlmagroGorbea y Torres, 2009; Almagro-Gorbea et alii, 2009), pero su menor representación en el Noreste debe considerarse una característica que se puede interpretar como un indicio indirecto de una temprana tendencia hacia la helenización.

Según opinión de M. Torelli (2002, 120), el uso de sellos con representaciones de divinidades se distanciaría de una autorrepresentación mediante la imagen del Dios y, en cambio, demostraría una exhibición de la devotio del propietario que aseguraría, al mismo tiempo, una protección directa al portar la imagen de la divinidad en su talismán. Sin embargo, también caben otras interpretaciones, pues la recurrencia de figuras de guerrero y otras asociadas a mitemas relacionados con el Héroe Fundador permiten relacionar los escarabeos en dichos casos con esa conocida figura mítica (Almagro-Gorbea y Lorrio, 2011).

Otro conjunto de representaciones son los animales reales y los seres míticos relacionados con la 
divinidad, de la que eran su símbolo, conjunto en el que cabe incluir unas 31 representaciones. Destacan las 8 representaciones del león, en muchos casos como símbolo jeroglífico, mientras que en otros aparece de manera explícita como el animal símbolo de la divinidad suprema, como en Oriente, tal como evidencia el ejemplar de la tumba Marti 15 de Ampurias (AMP11), simbolismo que pasó al mundo mítico tartesio-ibérico, como documenta el monumento de Pozo Moro (Almagro-Gorbea, 1983; Almagro-Gorbea, 2010a, 184 s.). Es interesante que en muchos casos el león aparece asociado a un símbolo solar circular (CC4, CC8, CC14, SOL1), bien conocido en la tradición céltica hispana (Almagro-Gorbea y Torres, 1999, 70) y norpirenaica (Green, 1992), mientras que en otros se asocia a la flor de loto como símbolo de la vida (MM3) o aparece como la fiera que ataca a una cabra o antílope como símbolo del poder real y del triunfo del Bien sobre el Mal (AMP7 y ILL1 con antílope). Esta asociación tan precisa procede de la ideología oriental del poder, lo que quizás explique su total desaparición tras el Periodo Orientalizante, como se observa en la escultura ibérica (Almagro-Gorbea, 2010b, 375 s.).

Otro ser mítico tan popular casi como el león es la esfinge, en algún caso igualmente usada como símbolo epigráfico, pero generalmente representada aislada o, en todo caso, también asociada a un círculo solar. Son 8 las esfinges identificadas en escarabeos (CC10, CC11, MM1, MM4, AMP18, AMP21, EC2, EC 3) y, como ocurre con los leones, todas aparecen en ejemplares del siglo VI a.C., pues aunque este ser mítico perduró en el imaginario ibérico tras helenizar sus formas (Chapa, 1980; 1986), no parece haber ocurrido lo mismo en sus representaciones en escarabeos.

Por el contrario, ofrecen más interés las 4 representaciones de grifos, animal mítico de origen oriental que se helenizó y arraigó profundamente en la cultura ibérica. El grifo del escarabeo AMP6 es etrusco y el LP1, posiblemente ya romano, mientras que el representado en el cowroid de Tossal del Moro (TM1) parece ser egipcio del siglo VI a.C., por lo que cabe relacionarlo con las representaciones del animal en marfiles (Le Meaux, 2005, fig. 2; Almagro-Gorbea, 2008, 405 y ss. y 506) y en cerámicas fenicio-tartesias (Belén et alii, 1997, 145 y ss.; Blánquez y Belén, eds., 2003). Sin embargo, conviene llamar la atención sobre la escena de grypomachia representada en el gran escarabeo naucrático de la tumba 11 de la Necrópolis NE de Ampurias (AMP12). Esta iconografía es ajena al mundo egipcio, aunque era originaria y característica del mundo oriental, desde el que pasó a Tartessos, como evidencian los marfiles (Almagro-Gorbea, 2008, 506), como igualmente desde Oriente pasó también a Grecia. El escarabeo AMP12 parece documentar cómo desde Jonia, ya a mediados del siglo VI a.C., el mitema de la grypomachia había arraigado entre las élites gentilicias de los Campos de Urnas, lo que ayuda a comprender su aparición en la Cultura Ibérica, seguramente asociado a mitos del Héroe Fundador

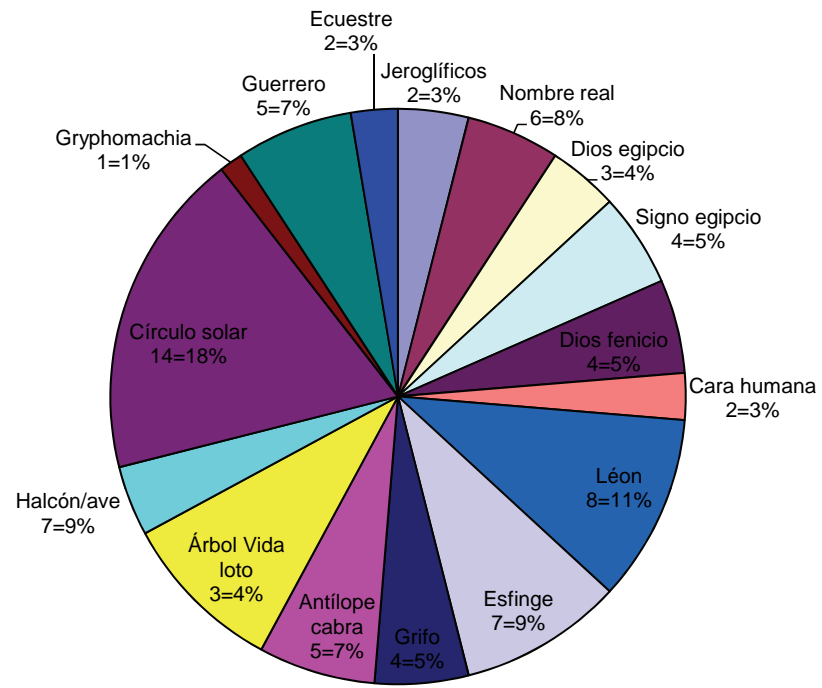

Figura 8: Principales tipos iconográficos identificados en los escarabeos del arco noroeste del Mediterráneo.

(Almagro-Gorbea, 2009a; Almagro-Gorbea y Lorrio, 2011). La grypomachia del escarabeo AMP12 constituye el precedente directo de la del herôn de Porcuna (Blanco Freijeiro, 1987; Olmos, 2002) y de otras representaciones helenizantes del tema a juzgar por su estilo jonio-ibérico o íbero-focense, como en la plaquita con una grypomachia de Cabezo Lucero (Uroz, 2006), cuyo estilo no es posterior al 500 a.C. Estas piezas manifiestan ya a inicios del siglo $\mathrm{V}$ a.C. el relevante papel que debieron haber tenido los focenses en la difusión de mitos asociados a la ideología heroica del Héroe Fundador, que pasó a ser uno de los elementos más importantes como sustento del poder de las élites emergentes, por lo que a los focenses cabe atribuir su propagación entre las élites detentadoras del poder en el mundo ibérico originario del substrato de los Campos de Urnas (Almagro-Gorbea, 1996, 77 s.), proceso que puede considerarse el inicio de la helenización ideológica de la sociedad ibérica, que, sin solución de continuidad, prosigue hasta la Romanización.

También destaca la relativa abundancia de representaciones de aves, en especial del Halcón solar o de Horus (AMP17, LP3, CC12, MM1, MM2), así como una de buitre (CC10) y otra indeterminada (MON1). Se trata de símbolos epigráficos o iconográficos de la cultura egipcia y, por extensión, del mundo fenopúnico, pero cabe sospechar que su uso por los indígenas pudiera indicar sincretismos con creencias ancestrales propias de su substrato indoeuropeo. Así debe interpretarse la relativa abundancia que suponen 14 escarabeos con un círculo interpretable como símbolo solar (MM2-3, MM5, MON1, CC4-CC6, CC10-CC15), en ocasiones asociado al león (SOL1) y a otros animales, frecuencia del círculo que cabe asociar a las concepciones cosmológicas celtas simbolizadas en la rueda (Green, 1992; Almagro-Gorbea y Torres, 1999, 70). Otro motivo de origen egipcio y 
oriental que pudo tener una interpretación propia en la mentalidad indígena son las piezas decoradas con cabezas humanas, ya sea en su anverso (AMP16) o en su sello (MON2). Piezas similares son los escarabeos de Porto do Sabugueiro-1, otro recientemente hallado en Huelva (M. Torres, comunicación personal) y otro de Mesas de Asta, en Cádiz, además de los escaraboides con "cabezas cortadas" del Tesoro de de Aliseda (Almagro-Gorbea, 1977, lám. 32B; Almagro-Gorbea et alii, 2009, $\mathrm{n}^{\mathrm{o}} 17$ ), cuyas cabezas hay que relacionar con las que ofrecen las joyas orientalizantes de los Celtici del Suroeste (Berrocal, 1989). Por ello, resulta lógico poner en relación esos escarabeos del Noreste de Hispania con el monumento de San Martí sa Roca, en Cataluña (Sanmartí, 1994), y con la tradición de las 'cabezas cortadas o 'têtes coupés' de la Galia mediterránea (Benoit, 1957; Langloys, 2000), ya que debieron ser interpretados desde la ideología heroica de las poblaciones celtas del Occidente de Europa.

Por último, entre las figuras simbólicas de origen egipcio también se documenta el uraeus (EC1, TOR1, PN1), el anq o Signo de la Vida (AMP13 y PN1) y una posible figura de gato? (MON1), cuya interpretación desde la perspectiva local resultan más problemáticas. Lo mismo cabe decir de la pluma maat (SOL1?, MM1, CC7, LP3, EC2 y AMP3?), cuyo significado por el momento debe considerarse con precaución, ya que no parece ser un motivo muy recurrente en el ámbito ibérico ni tartésico, a pesar de su frecuente presencia en jeroglíficos y de su evidente significado escatológico, dado que en la mitología egipcia la pluma de avestruz era el atributo de Maat, la diosa de la Justicia y del Orden Cósmico, que presidía el fiel de la balanza junto a Thot, el dios de la Sabiduría, en el juicio en que se pesaba el corazón del muerto ante el Tribunal de Osiris, para saber si el difunto ha superado su condición humana y su alma está libre para ser conducido al reino de Osiris, pues dicha pluma simbolizaba la ligereza espiritual frente al cuerpo material, lo que permite suponer que tuviera dicho simbolismo en los escarabeos.

Tras los símbolos de origen egipcio, adoptados en su mayoría por los fenicios y púnicos, se deben relacionar los que son propiamente fenicios. Los escarabeos fenicios resultan relativamente escasos en el Nordeste de Hispania, por lo que sus esquemas iconográficos se reducen a 5 ó 6 , de los que sólo 4 ofrecen imágenes de divinidades, a las que cabría añadir los escarabeos ya citados de Isis con Horus (LAT1, AMP3), dada su arraigo y popularidad en el mundo púnico. Entre los escarabeos con iconografía oriental el más interesante es el que ofrece una figura de estilo griego arcaico de un dios sobre el lomo de un león (AMP11). Su fecha puede colocarse a fines del siglo VI a.C., antes del 500 a.C. en todo caso, pero su identificación con una divinidad concreta, sea del panteón fenicio, púnico o griego no resulta segura, ya que lleva en la mano una rama, que podría ser el atributo de Baal en el mundo fenicio o la rama de lustración de Apolo para un griego. Este escarabeo AMP11 es, junto al de la tumba Muralla NE 11 (AMP12) con una grypomachia, otro de los más interesantes de toda esa región, por no decir de toda Hispania. La talla cabe atribuirla por su calidad a un taller helénico, como confirma un detalle tan esencial como la concepción desnuda de la divinidad, que se conjuga bien con su composición y estilo griegos. Sin embargo, su iconografía es característica del mundo fenicio y piezas de estilo similar se han señalado en Cartago (Vercoutter, 1945, 227, 244, $n^{\circ} 602,672$, lám. XVII, XIX), lo que lleva a concluir, no sin dudas, que quizás fuera labrada para un fenicio, muy helenizado en una fecha tan temprana como el siglo VI a.C., en un taller helénico en estrecho contacto con las creencias y la iconografía de Oriente, quizás en Chipre o en la Grecia Oriental.

También es característica la escena de una persona ante un árbol que ofrece el sello de plata PN1, que cabe interpretar como una diosa, seguramente HathorAstart-Asherat ante el Árbol de la Vida. Otra figura característica es el personaje pisciforme del escarabeo de Ampurias AMP8, que cabría relacionar con el dios marino Yam, aunque en un contexto griego esta figura pudo ser interpretada como Typhon o como un Tritón, ya que su estilo es helenizante, si bien el símbolo astral que ofrece en el campo revela su relación con la cosmología oriental, pues es una figura bien documentada en escarabeos feno-púnicos. La figura de Bes (RO1) no ofrece dudas de su origen feno-púnico, donde resulta muy frecuente su aparición en escarabeos como divinidad apotropaica (Boardman, 2003, tipo 22). Respecto a los animales que aparecen en escarabeos de origen fenicio ya se ha hecho referencia a los que son de origen egipcio (vid. supra). A ellos cabe añadir 5 escarabeos con un antílope o una cabra, animales no siempre fáciles de distinguir uno de otro en estas piezas (CC1, CC2, ILL1, CC5), en algún caso atacado por un león (AMP7). Ya se ha señalado que el antílope o cabra era un animal de la diosa Astart y que la escena del león que ataca a un cáprido o un antílope simbolizaría al dios-rey vencedor de sus enemigos y, por extrapolación, sería una representación del Mal vencido por el Bien. Aunque el antílope podía simbolizar a Tammuz, la cabra era el animal de Reshef en el área sirio-fenicia (Barnett, 1957, 88) y de la diosa Astart en la fenicio-palestina (Keel y Ühlinger, 1992, 166), donde sus templos tenían rebaños de cabras o gacelas (Mallowan y Herrmann, 1974, 10, n. 3). Más incierto queda en este contexto ideológico el significado del escorpión (AMP9), que cabe interpretar como símbolo divino con sentido apotropaico y quizás también astrológico, aunque su sentido concreto en el contexto que estamos analizando sea difícil de precisar.

Un último grupo formado por sólo 7 escarabeos ofrecen figuras y escenas que cabe relacionar con el mundo griego. Ya se ha hecho alusión al escarabeo de Náucratis con una grypomachia (AMP12) y al griego arcaico con una divinidad oriental (AMP11), que documentan la invisible transición entre las creencias de Oriente y de Occidente. Más habituales son 
las escenas de tipo heroico, generalmente expresadas por guerreros heroizados, pues se representan armados pero desnudos. En este grupo, en parte originario de talleres púnicos, probablemente sardos, pero también producidos por talleres etruscos, cabe incluir 1 escarabeo con una posible escena de Heracles y Cerbero (MON3) y 6 piezas con representaciones de guerreros heroicos (AMP4, AMP5, AMP20, AMP23, TB1, LP2), alguno de los cuales en sus modelos originarios pudo ser interpretado como Aquiles, Heracles o $\mathrm{Ka}$ paenus, el primero identificado en la escena en que se pone una cnémide para armarse, Heracles, por su clava y el último fulminado. Sin embargo en el contexto indigena hispano parece más lógico asociar este héroe, muchas veces sin atributos identificables, al Héroe Fundador, sea cual fuera su significado exacto, ya que estas representaciones serían interpretadas desde la ideología local en relación con mitos del Héroe Fundado (Almagro-Gorbea y Lorrio, 2011), cuya existencia ya testimonia el escarabeo con la grypomachia de Ampurias a mediados del siglo VI a.C.

Al mismo ámbito ideológico, pero a su aspecto ecuestre, cabría relacionar otros 3 escarabeos, reflejo de la aparición de nuevas elites de tipo ecuestres (Almagro-Gorbea, 1996, 79 s.): uno ofrece un Pegaso (ENS2), símbolo de Emporion y de Belerefonte como héroe ecuestre por excelencia, otro es una simple figura de jinete (AMP2), cuya interpretación entra de lleno en el campo de la heroización ecuestre, bien documentada en el ámbito púnico (Pisano, 1996) y en las abundantes representaciones del heros equitans Hispanus, sobretodo en monedas (Almagro-Gorbea, 1995); el tercero es una cuádriga (ENS3), que posiblemente aluda a la heroización de Heracles, tema representado en una de las páteras de Tivissa (Raddatz, 1969, 69 s. y 258 s.), que procede de un contexto regio de culto al antepasado (Almagro-Gorbea, 1996, n. 233). La frecuencia de estos temas indica que la elección de la iconografía heroica no es casual. Frente a lo anteriormente indicado respecto a la iconografía divina, para Torelli $(2002,126)$ las representaciones heroicas pretenderían identificar las virtudes del propietario con las de su héroe, aunque la ideología y las creencias de la Hispania prerromana plantean que, seguramente, esa figura mítica sería interpretada como un Héroe Fundador (Almagro-Gorbea, 2009a), esto es, como divinidad protectora de quien llevaba el escarabeo (Almagro-Gorbea y Lorrio, 2011).

Es interesante también llamar la atención sobre la total ausencia de otras figuras y símbolos populares bien conocidos en las áreas meridionales de la Península Ibérica y en el mundo feno-púnico, como el disco solar alado, el oudja o la vaca amamantando a su ternero, como ocurre con representaciones de divinidades púnicas tan populares como Baal sedente o las de Melqart, ausentes de esta región del noroeste del Mediterráneo a pesar de su frecuencia en Ibiza y en otras áreas de Hispania, como resulta igualmente significativo la casi total ausencia de representaciones tan habituales en el imaginario tartésico como el Árbol de la Vida (PN1) y la flor de loto (MM3, AMP13?). Todo lo dicho parece confirmar que estos seres y símbolos míticos tendrían su propio significado para quienes los usaban, apoyado por tradiciones literarias orales que se irían introduciendo desde el mundo colonial en el imaginario colectivo de las élites rectoras del Nordeste de Hispania y de la Galia mediterránea según su capacidad de adaptación al ideario procedente de su propio substrato cultural. El león, la esfinge y el grifo son animales relacionados con la diosa Astart y quizás también originariamente con la protección del monarca, lo que explicitaría su carácter apotropaico, relacionado de algún modo con cultos solares. Los halcones, aves y símbolos circulares cabe plantear que serían relacionados con la divinidad solar, como ciertamente el disco solar y quizás también el uraeus del escarabeo de Castejón, en Navarra. Por ello, el culto solar aparece como una de las principales ideas cosmológicas, sin que sea posible profundizar mucho más en este sentido.

Al margen del signo $n b$ y de la pluma maat, que no se han contabilizado, los temas iconográficos identificados pueden ser analizados según su frecuencia. El grupo más numeroso lo constituyen los animales míticos divinos o sagrados, como leones $(8=11,5 \%)$, esfinges $(8=11,5 \%)$, grifos $(4=5,8 \%)$, cabras o antílopes $(5=7,2 \%)$ y el Halcón solar y otras aves $(7=10 \%)$, que suman en conjunto un $46 \%$, más de un tercio de todas las representaciones. A continuación cabe señalar las divinidades, egipcias (4=5,8\%), feno-púnicas $(4=5,8 \%)$ y los dioses y héroes de tipo heleno $(8=11,5 \%)$, a los que hay que añadir las 'cabezas humanas' $(2=2,9 \%)$, conjunto que suma en total 18 escarabeos, un $25 \%$. Tras estos dos grupos, destacan el simple círculo solar, atestiguado al menos en 14 piezas, un $21 \%$. El puesto siguiente lo ocupa los escarabeos con inscripciones jeroglíficas, que suman en total 7 piezas, un $9 \%$, destacando los 4 que ofrecen título real (6\%). Quedan, por último, 4 con signos egipcios (6\%), 3 con lotos o con el 'Árbol de la Vida (4,5\%) y los que hacen referencia a la heroización ecuestre, documentada en 3 escarabeos, otro 4,5\%.

La escasez de la muestra hace que sea difícil hacer un análisis diacrónico de la evolución de los motivos iconográficos (Fig. 9). Sin embargo, cabe diferenciar una etapa inicial, en la que predominan las piezas de origen egipcio, por lo que la iconografía corresponde a inscripciones jeroglíficas con nombres de faraones y divinidades egipcias y animales y símbolos de la mitología egipcia. Esta fase parece datarse a partir de fines del siglo VII a.C., aunque parece más probablemente que este tipo de escarabeos pertenezcan a la primera mitad del siglo VI a.C.

Una segunda fase corresponde al apogeo del Periodo Orientalizante en el Sur de Hispania, en la cual la mayor parte de las piezas y, por tanto, sus motivos iconográficos, son de tipo fenicio o más bien púnico, aunque verosímilmente eran interpretados desde una 


\begin{tabular}{|c|c|c|c|c|c|c|c|c|c|}
\hline & $650-600$ & $600-550$ & $550-500$ & $500-450$ & $450-400$ & $400-350$ & $350-300$ & $300-$ & total \\
\hline Nombre real & 3 & 3 & & & & & & & 6 \\
\hline Jeroglíficos & 3 & 5 & & & & & & & 8 \\
\hline Dios egipcio & 1 & 1 & & & & & & & 2 \\
\hline Antílope-cabra & 2 & 3 & 1 & & & & & & 6 \\
\hline Léon & 1 & 6 & 1 & & & & & & 8 \\
\hline Signos egipcios & 1 & 1 & & & & & & 1 & 3 \\
\hline Esfinge & & 7 & & & & & & & 7 \\
\hline Grypomachia & & 1 & & & & & & & 1 \\
\hline Círculo solar & & 15 & 1 & & & & & & 16 \\
\hline Árbol de Vida/loto & & 1 & 1 & 1 & & & & & 3 \\
\hline Cara humana & & 1 & & 1 & & & & & 2 \\
\hline Halcón/ave & & 4 & 1 & & & 1 & & 1 & 7 \\
\hline Grifo & & 1 & & & & & 1 & 1 & 3 \\
\hline Dios fenicio & & & 2 & 3 & 2 & 1 & 1 & & 9 \\
\hline Heroización ecuestre & & & & & 1 & 1 & 1 & & 3 \\
\hline Guerrero heroico & & & & & 1 & 3 & 1 & 2 & 7 \\
\hline Total & 11 & 49 & 7 & 5 & 4 & 6 & 4 & 5 & 91 \\
\hline
\end{tabular}

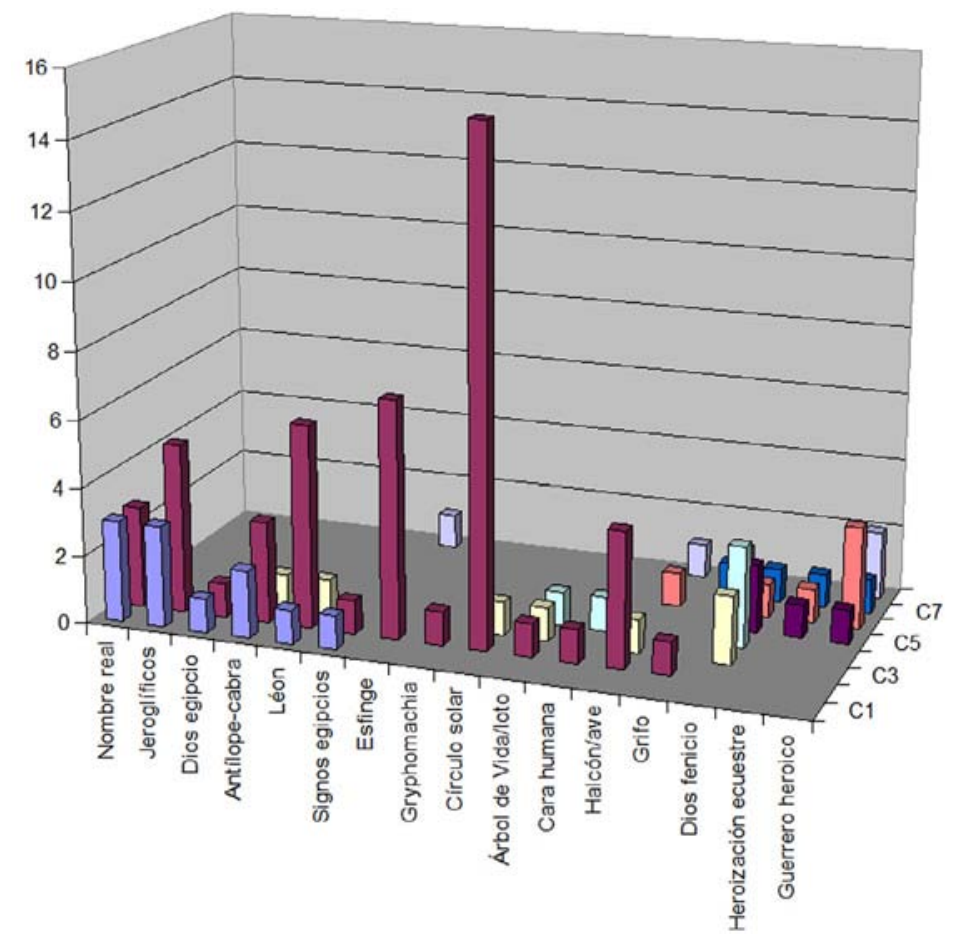

Figura 9: A-B, Evolución cronológica de la iconografía de los escarabeos del arco noroeste del Mediterráneo.

cosmología local de concepción solar. Esta fase se puede considerar iniciada ya a partir del siglo VI a.C. y parece perdurar hasta el siglo $\mathrm{V}$ a.C.

Como se constata en el Sur de Portugal y en Extremadura, es evidente que los escarabeos no ofrecen casi temas helenizantes hasta avanzado el siglo $\mathrm{V}$ y con seguridad en el siglo IV a.C., cuando se generalizan representaciones de carácter guerrero o ecuestre, con una iconografía claramente helenizante, que sustituye los motivos procedentes del Periodo Orientalizante, probablemente como reación contra las élites regias de carácter sacro de dicho periodo
(Almagro-Gorbea, 1996, 41 y ss., 79 ss.; Torres, 2002, 380 y ss.).

A pesar de esta neta diferenciación entre ambas fases, es difícil realizar la adscripción tipológica de las piezas a talleres concretos, pues no es fácil precisar el origen de estos escarabeos, hecho relativamente habitual con los hallados en Hispania. A juzgar por sus características, gran parte de los escarabeos de pasta proceden de Náucratis, mientras que sólo una minoría parecen ser escarabeos manufacturados en talleres egipcios de Época Saíta, como, probablemente, los de El Castillo de Castejón, EC1 a EC3. Este 
hecho destaca frente a la presencia de sólo 3 productos naucráticos en Portugal y prácticamente ninguno en Extremadura ni en Villaricos y parece confirmar la relación de estos productos con el comercio focense, tal como se ha señalado, aunque podría considerarse también una mediación etrusca (Graells, 2010, 189). Por el contrario, son escasos los escarabeos con representaciones iconográficas figuradas que pueden considerarse fenicios o de procedencia mayoritariamente cartaginesa, más habituales en las áreas citadas de la Hispania meridional.

Por último, cabe señalar la aparición de representaciones originarias de talleres sardos a partir del siglo V a.C., en clara competencia con los escarabeos etruscos que empiezan a llegar, unos y otros con representaciones helenizantes derivadas de las creaciones de época arcaica avanzada, aunque hay que insistir sobre la práctica ausencia de escarabeos griegos y etruscos arcaicos, a excepción del ejemplar AMP11, ya comentado.

Más interesante resulta un análisis diacrónico de los motivos (Fig. 9), que permite apreciar tres etapas. A una fase inicial, que corresponde al Periodo Orientalizante en el Sur de Hispania, pertenecen la mayor parte de las piezas y de los motivos iconográficos, cuyo auge se sitúa en la primera mitad del siglo VI a.C., aunque perdura hasta fines de dicho siglo, si bien en el siglo $\mathrm{V}$ se percibe una clara disminución, casi una ruptura, hasta una cierta recuperación en la fase final representada por la aparición de temas helenizantes a partir de la segunda mitad del siglo V a.C.

Entre los motivos orientalizantes, destacan el valor "mágico" de la escritura con signos jeroglíficos, atestiguada desde inicios del siglo VI a.C. hasta fines del mismo. También aparece entre las piezas más antiguas los animales de la divinidad, como leones, esfinges y grifos, si bien estos últimos perduran y enlazan con los escarabeos etruscos de la última fase.

También aparece alguna divinidad de tipo fenicio, que sólo representa una mínima parte del amplio repertorio del panteón fenicio, tradición que prosigue en la segunda mitad del V a.C., ya dentro de las tradiciones púnicas. La mayoría de los animales míticos se atestiguan en el siglo VI a.C. y vuelven a aparecer en el siglo V a.C., mientras que son escasas las representaciones de lotos y del Árbol de la Vida, fechadas en la segunda mitad del siglo VI a.C. Los escaraboides con "cabezas cortadas" se pueden fechar en el siglo VI a.C.

Tras el hiato que supone la primera mitad del $\mathrm{V}$ a.C., es interesante observar el cambio producido en la iconografía de los escarabeos documentados. Aparece en esta nueva fase la figura de Isis con Horus según el esquema púnico, pero la novedad más importante parece ser la aparición de figuras de guerreros heroizados, en un caso a caballo, pero en su mayoría a pie con armas o en el momento de armarse, que evidencian ya una clara iconografía heroica de origen helénico. Estas piezas ofrecen un estilo helenizante, pero proceden de talleres púnicos y etruscos (vid. supra). Sin embargo, su interés principal es que esta nueva iconografía evidencia la generalización de cambio iconográfico muy general por toda Hispania, que se debe relacionar con la sustitución de las monarquías sacras por nuevas élites de tipo heroico, más cercanas al ideario griego, a lo largo del siglo V a.C., cambio que refleja una clase guerrera aristocrática de tipo heroico que supone una nueva concepción socio-ideológica, basada en el antepasado heroico, seguramente de carácter mítico, como sustento del poder a partir de esas fechas, frente a la tradición orientalizante de élites regias de carácter sacro del mundo orientalizante (Almagro-Gorbea, 1996, 41 y ss.; Torres, 2002, 380 y ss.).

En resumen, el análisis de la iconografía de los escarabeos permite observar una evidente evolución socio-ideológica, con interesantes variaciones respecto a otras áreas geográficas de la propia Hispania. Las diferencias diacrónicas observadas reflejan variaciones iconográficas producidas en los centros productores de los escarabeos desde el siglo VII a.C. hasta finales del IV a.C., de acuerdo con las corrientes estilísticas y comerciales del Mediterráneo y con la evolución general de los pueblos ribereños hacia formas de vida cada vez más próximas al mundo urbano o 'civilizado'. Además, estas variaciones, todavía apenas documentadas, dejan percibir cambios ocurridos en la ideología y creencias de las élites que adquirían estas preciadas piezas, por su significado mágico y apotropaico y por su prestigio social, por lo que sus creencias y gustos debían orientar las ofertas del mercado y la selección de los temas, a la vez que las representaciones que ofrecían y, sobre todo, los mitos que éstas indicaban contribuían a sustentar el poder, lo que explica la reiteración de los tipos, que indica la plena comprensión de los temas por la élites que los adquirían.

En este sentido, la iconografía de los escarabeos del Nordeste de Hispania, lo mismo que se ha señalado en áreas meridionales de la misma, documenta la evolución religiosa e ideológica de las élites, por lo que, a medida que se logre 'descodificar' este mundo de imágenes, se podrá penetrar y analizar mejor no sólo el significado concreto de cada tema, sino la evolución del pensamiento, para cuyo conocimiento los escarabeos constituyen una de las mejores fuentes existentes.

\section{ConteXto SOCIO-IDEOLÓGICO.}

Un aspecto muy importante de los escarabeos es la información que ofrecen sobre su contexto socioideológico, para lo que resulta muy significativo hacer una comparación, aunque no sea muy detallada, con los abundantes escarabeos recuperados en otros puntos del Mediterráneo. En el ámbito del Egeo, los santuarios de Perachora permiten observar una proximidad tipo-cronológica entre sus series de escarabeos y los ejemplares antiguos recuperados en Cataluña, 
pues se observa, aunque con una concentración mucho mayor, series de escarabeos de finales de siglo VII e inicios del siglo VI a.C., a pesar de que las leyendas induzcan a pensar en cronologías más altas, incluso de mediados del II milenio a.C., ya que, como se ha señalado en distintos ejemplos, las producciones saítas debieron recuperar dichas leyendas en sus nuevas producciones. De este modo se puede concluir que los tipos de escarabeos documentados en territorio catalán y en regiones vecinas corresponden a producciones concentradas en un mismo momento entre finales de siglo VII e inicios del siglo VI a.C. Este hecho es un curioso dato a retener para las conclusiones finales sobre la tumba X de la necrópolis del Mas de Mussols y para comprender el tipo de comercio y el tipo de producciones que llegaron a las distintas comunidades del Nordeste a inicios de la primera Edad del Hierro. Esta concentración de aegyptiaca, sincrónicos a los contextos de amortización, de un mismo período y repartidos en un territorio tan vasto de manera exclusiva, no se documenta en ningún otro contexto mediterráneo, pues únicamente las cuentas de collar de pasta vítrea pueden relacionarse con este tipo de producciones ${ }^{5}$.

Los escarabeos egipcios y de tipo egipcio en Etruria y en la Italia Meridional tirrénica se concentran entre finales de siglo del VIII e inicios del VII a.C. (MorettiSgubini, 2003, 22; Timperi, 2001, 199, III.B.1.62-63 y 206, III.B.2.31), mientras que la presencia de escarabeos se documenta en un momento posterior en la orilla adriática italiana ${ }^{6}$. El auge de su uso se relaciona con el surgimiento de las distintas aristocracias locales en el pleno cénit de los intercambios comerciales

5. En relación con la presencia de escarabeos debe considerarse el hallazgo de cuentas de pasta vítrea, fayenza o directamente en vidrio y colgantes realizados en conchas de diversos tipos. Se encuentran en un número pequeño de tumbas y normalmente con pocos ejemplares en cada tumba. Para el caso de las cuentas de pasta vítrea, fayenza y vidrio, lejos quedan los grandes collares del sur de la Península Ibérica o de Italia. Seguramente, la presencia de estas cuentas de collar deba relacionarse con el gusto por decorar los collares con elementos importados con colores y brillos, como bien lo ejemplifican los diferentes escarabeos que anteriormente han sido presentados de las necrópolis de Mas de Mussols, Can Canyís, la Muralla N.E. de Ampurias, Puig de la Nau (Padró 1982-1983), La Solivella o Peralada. Viene a reforzar esta idea el hallazgo conjunto de cuentas de pasta vítrea y un escarabeo naucrático en la tumba 6 de la Solivella (Padró, 1974b, 72) o la tumba 70 de la necrópolis de Coimbra del Barranco Ancho con una cuenta idéntica a la recuperada en Milmanda (Graells, 2008, 80-81, fig. 52) asociada a cuatro escaraboides (García-Cano, 1997, 261-263).

6. Éste es el caso de la tumba 8 de la necrópolis de Pianello di Castelbellino (Capriotti-Vittozzi, 1999a, 231, no 352), atribuido a una producción de Psamético I con características similares al ejemplar de Tossal del Moro de Pinyeres, o la tumba 47 de la necrópolis de Campovalano (Capriotti-Vittozzi, 1999b, 231-232, no 353), igualmente producción naucrática de cronología a caballo entre los siglos VII y VI a.C., y un fenómeno semejante se observa en Sicilia. mediterráneos (Martelli, 2000, 455-456). Otros dos escarabeos egipcios se han recuperado en las tumbas 36 de la necrópolis Lippi de Verrucchio (fines del siglo VIII-inicios del VII a.C.) y 4 de la necrópolis Le Pegge, también en Verrucchio (pleno siglo VII a.C.), que han sido relacionados con los colgantes de pasta vítrea de la tumba 89 de la necrópolis Lippi de Verrucchio (Gentili, 2003, 48 y 226, tavv.12 y 106; Malnati, 2004, 82; von Eles, 2002, 174). Por otro lado, también han sido señalados algunos escarabeos en las necrópolis de Marsigliana d'Albegna y de Vetulonia (Bartoloni et alii, 2000, 137-138) y al menos en una tumba de la fase Arnoaldi de la necrópolis de Bolonia (Malnati, 2004, 83). Esta circulación de aegyptiaca se considera para el área norte de los Apeninos y del Piceno fruto del comercio etrusco y del intercambio de éste con la colonia de Pythekoussai, donde los escarabeos son frecuentes, especialmente como amuletos en tumbas infantiles.

En fechas recientes, J. Padró (2002-2003, 248) ha señalado a partir de los resultados obtenidos en el análisis de los escarabeos aparecidos en contextos itálicos que cabe suponer una función apotropaica de estos elementos y no únicamente una función ornamental. Por otro lado, respecto al uso y tratamiento que los escarabeos recibían, cabe señalar que en la necrópolis de Can Canyís, según D. Bea (1996), ninguno de los ejemplares presentaba evidencias de cremación o fusión, por lo que se supone que no habrían sido incluidos en la cremación. Este hecho se contrapone a la mayoría de las piezas de ornamentación personal y de vestuario que caracteriza el ritual de la necrópolis de Can Canyís, que sí presentan abundantes muestras de cremación, por lo que las piezas en cuestión recibieron un trato preferencial en el ritual funerario al depositarse al margen, separadas del resto de los ajuares ${ }^{7}$, tal vez como preciadas ofrendas post mortem. Como hemos visto con las otras producciones importadas en contextos funerarios del Nordeste, pierde su fuerza comercial y especialmente su representación en el registro funerario como elementos de prestigio.

Como ocurre en otros yacimientos de la Península Ibérica y de todo el Mediterráneo, la aparición de escarabeos como parte del ajuar funerario indica que fueron utilizados con su significado original, ya que eran amuletos mágicos con un marcado significado apotropaico y profiláctico, que tras ser usados para proteger al difunto en vida posteriormente garantizaban su tránsito al Más Allá (Vercoutter, 1945, 11; Bianchi, 1984, 968 y ss.). Pero también tendrían función de objeto representativo del papel social de su poseedor como sellos y marcas de propiedad de sus usuarios (Marras, 1990, 52 y 58; Bergès, 1998), con lo que ello supone en el orden social, hecho que en ocasiones pasa

\footnotetext{
7. Se utiliza la expresión "separadas" en referencia al tiempo y al orden, no en relación al espacio, ya que éste resulta desconocido.
} 
desapercibido y que no está atestiguado en estas zonas del Nordeste, aunque no se deba excluir en principio, pues éstá bien documentado en el ámbito tartesio del Tesoro de Aliseda, de la necrópolis de Medellín o del palacio-fortín de Cancho Roano (Almagro-Gorbea y Torres, 2009). En todo caso, el uso de escarabeos ofrece una connotación de símbolo de estatus social (Almagro-Gorbea, 2008).

La falta de documentación sobre el contexto de muchas de las piezas impide conocer si ofrecen desfases entre la fecha teórica de su fabricación y la de su deposición en la tumba, que puede oscilar entre coincidir con la fecha de fabricación o tener 50 o más años de desfase en el momento de su deposición en la tumba, como se ha observado en otras zonas (Almagro Gorbea y Almagro-Gorbea, 2009; Almagro-Gorbea et alii, 2009) y como evidencia el escarabeo AMP11 de la inhumación Martí 15. Estos lapsos parecen lógicos respecto al uso y funciones de estas piezas, ya que no hay por qué excluir que en algún caso incluso se heredaran, lo que pudo mantenerlas en uso durante una o varias generaciones, como indicarían los desfases señalados. Pero la falta de precisión de las excavaciones antiguas y la ausencia de un trabajo de revisión analítica de sus contextos arqueológicos impide afinar su cronología, muchas veces incierta por carecer de buenos datos la excavación, por lo que la cronología resulta excesivamente amplia para poder precisar la fecha de estos materiales tan característicos.

También sería interesante conocer la proporción con que aparecen los escarabeos en las sepulturas de las necrópolis para poder compararlos con otros cementerios con datos conocidos. En Medellín su número es claramente inferior al documentado en otros cementerios del mundo colonial púnico (Almagro-Gorbea, 2008), donde están presentes casi en el $50 \%$ de las sepulturas, a juzgar por los numerosos escarabeos hallados en Cartago, con una proporción de 1:2 en la necrópolis de Dermech y 4:9 en Junon (Vercoutter, 1945, 15), proporción igualmente elevada en Ibiza, aunque en sus necrópolis no se ha llegado a cuantificar con precisión el número de escarabeos por sepultura (Fernández y Padró, 1982; Boardman, 1984). Igualmente, en Villaricos, a excepción del grupo E (Astruc, 1951; Almagro Gorbea y Almagro-Gorbea, 2009), la proporción general es de $<1: 10$, menor que la de otras necrópolis púnicas rurales, como la de Jardín (Málaga), cuya proporción de 2:101 supone un 2\% (Schubart y Maass-Lindemann, 2007, 328), proporción semejante a la que ofrece la necrópolis orientalizante tartesia de Medellín, en la que los escarabeos y escaraboides aparecen en una proporción de 1:40 por tumba, esto es, un $2.5 \%$. En cualquier caso, tal como se ha señalado, los escarabeos deben considerarse un elemento de estatus social, hecho claramente reconocido y apreciado en la sociedad hispano-fenicia y tartesia (Almagro-Gorbea, 2008), aunque sea casi desconocido el sexo y el contexto social de la mayoría de las tumbas en las que han aparecido los escarabeos del Nordeste de Hispania.
Los 72 escarabeos hasta ahora documentado en esta región se encuadran en el amplio proceso cultural que representa la colonización griega y la helenización, frente a su relación con el proceso orientalizante de las áreas meridionales de la Península Ibérica, que aparece fuertemente ligado a los fenicios (Blázquez, 1975; Almagro-Gorbea, 1977; Torres, 2002; Koch, 1984, 2004; Celestino y Jiménez Ávila, eds., 2005), aunque, en un marco más amplio, el uso de escarabeos entre las poblaciones del Nordeste de la Península Ibérica, debe considerarse consecuencia del proceso de helenización sufrido por el Mediterráneo desde el siglo VI al IV a.C.

\section{CONCLUSIONES}

Este trabajo dedicado al análisis de los 72 sellos y escarabeos aparecidos en el Noreste de la Península Ibérica permite comprender la función y el significado de estas piezas desde la perspectiva de quienes las adquirían, lo que ayuda a precisar los datos hasta ahora ofrecidos por las visiones de conjunto dedicadas a analizar los materiales egipcios y egiptizantes de la Península Ibérica importados por los fenicios (Gammer-Wallert, 1978; Padró, 1985 a 1987; García Martínez, 2001).

La primera conclusión que resulta evidente es la amplia dispersión de las piezas, que alcanzaron el Valle del Ebro y las costas de la Galia mediterránea, aunque su difusión se limita en la inmensa mayoría de los casos a las áreas costeras.

Muy interesante es el hecho de que la aparición de los escarabeos se produce en esta región en un momento tan avanzado como el siglo VI a.C., probablemente en su inicio, en el momento de auge de la colonización focense, a cuya actividad parece deberse la aparición de la inmensa mayoría de las piezas. Por otra parte, su aparición puede considerarse indicio de relaciones con gentes originarias del ámbito urbano, fuera del cual estos escarabeos quizás carecieran de significado por el menor grado de desarrollo socio-económico, a pesar de su evidente carácter mágico.

En la fase de introducción predominan una mayoría de escarabeos de Náucratis junto a algunos egipcios y, quizás, con alguno de origen fenicio. Pero, a partir de la segunda mitad del siglo VI a.C. se percibe una fuerte crisis y un claro cambio en los gustos y en la ideología que éstos reflejan, pues las piezas egipcias fueron sustituidas por productos fenicios y púnicos y al final también por etruscos, con la consiguiente desaparición de los jeroglíficos con nombres de faraones, con criptogramas divinos y con fórmulas mágicas de protección, sustituidos por escenas iconográficas parlantes de divinidades y de animales míticos protectores, cuya creciente variedad de tipos, de talleres de origen y de representaciones refleja la creciente apertura al Mediterráneo y, en concreto, la de esas áreas de la Península Ibérica, abocadas de modo progresivo a la helenización. 
En resumen, los escarabeos del Nordeste de Hispania y de la Galia mediterránea conforman un conjunto coherente y representativo para comprender la función de estas piezas desde la perspectiva indígena, a la vez que ayuda a documentar los complejos procesos comerciales y culturales en las zonas de influjo focense. Igualmente, confirman de nuevo el hecho, cada día mejor documentado, de que su significado religioso, su simbolismo mágico protector y su función de símbolo de estatus personal era perfectamente conocidos por quienes los adquirían y usaban, ya que sus imágenes serían comprensibles para las élites que los adquirían. En consecuencia, como repetidas veces se ha señalado, los cambios que ofrece su iconografía indican cambios en la mentalidad y la ideología de las élites indígenas, que resultan paralelos a los observados en otros ámbitos del Mediterráneo, lo que prueba una vez más la inserción del estas áreas del Mediteráneo en las grandes corrientes culturales e ideológicas en la Antigüedad.

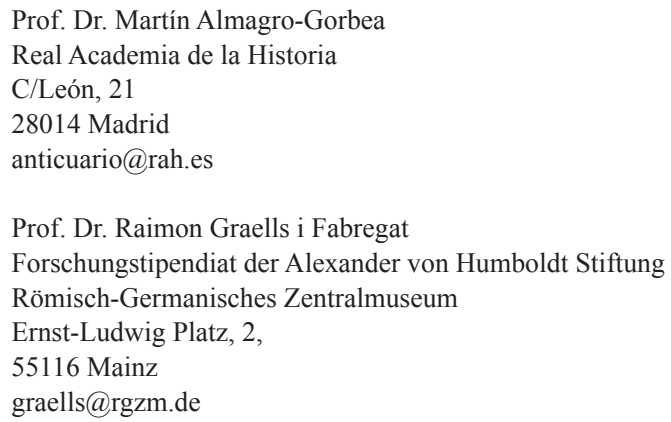

\section{BIBLIOGRAFÍA}

AA.VV., 2002: Castejón.Cuatro milenios de Historia, Castejón.

AA.VV., 2005: La fragilitat en el temps. El vidre a l'antiguetat (catálogo de exposición), Girona.

ACQUARO, E., 1980: "Due falsi punici", Rivista di Studi Fenici, 8, 43-46.

ACQUARO, E., 1986: "Motivi iconografici negli scarabei ibicenchi”, Aula Orientalis, 4, 105-110.

Aguilar, S., 1895: Ampurias, Figueres.

Almagro BASCH, M., 1953-1955: Las Necrópolis de Ampurias, I-II, Barcelona.

Almagro-GorbeA, M., 1977: El bronce final y el periodo orientalizante en Extremadura, Bibliotheca Praehistorica Hispánica 14, Madrid.

Almagro-GorbeA, M., 1982: "Escarabeo etrusco", en M. Almagro-GorbeA (ed.), El Santuario de Juno en Gabii. Excavaciones 1956-1969, 51-252, lám. 40,1, Madrid-Roma.

Almagro-GorbeA, M., 1995: La moneda hispánica con jinete y cabeza varonil ¿Tradición indígena o creación romana?, Zephyrus, 48, 235-266.

Almagro-Gorbea, M., 1996: Ideología y Poder en Tartessos y el mundo ibérico. Discurso de ingreso en la Real Academia de la Historia, Madrid.
Almagro-GorbEA, M. 2008: "Escarabeos y escaraboides", en M. Almagro-Gorbea (ed.), La necrópolis de Medellín. II, Estudio de los hallazgos, Bibliotheca Archaeologica Hispana 26-2, 371-399, Madrid.

Almagro-GorbeA, M. 2008a: "Marfiles", en M. AlmAGRO-GORBEA (ed.), La necrópolis de Medellín. II, Estudio de los hallazgos, Bibliotheca Archaeologica Hispana 26-2, 371-399, Madrid.

Almagro-Gorbea, M., 2009a: "El culto al Héros Ktístes en Hispania prerromana: ensayo de mitología comparada", en M. GARCÍA QUINTELA (ed.), Veingt ans après Georges Dumèzil (1898-1986), Archaeolingua, Casa de Velázquez, 227-250, Budapest.

Almagro-GorbeA, M., 2009b: "La representación del guerrero", en M. Almagro-Gorbea (coord.), Prehistoria y Antigüedad, Historia Militar de España, I, 365373, Madrid.

Almagro-Gorbea, M., 2010a: "Los leones de Puente de Noy", en M. Almagro-Gorbea y M. TORRES, La escultura fenicia en Hispania, Bibliotheca Archaeologica Hispana, 171-185, Madrid.

Almagro-GorbeA, M., 2010b: "La escultura hispano-fenicia: características y significado", en M. ALMAGROGORBEA y M. TORRES, La escultura fenicia en Hispania, Bibliotheca Archaeologica Hispana, 333-396, Madrid.

Almagro Gorbea, M. J. y Almagro-GorbeA, M., 2009: "Los escarabeos de la necrópolis de Baria, Villaricos (Cuevas de Vera, Almería)", en Homenaje al académico Julio Más, 33-68, Murcia.

Almagro-Gorbea, M., Arroyo, A., Corbi, J. F. M. y MARÍN, B., 2009: "Los escarabeos de Extremadura: una lectura socioideológica”, Zephyrus, 63.1, 71-104.

Almagro-GorbeA, M. y Lorrio, A., 2011: Teutates. El Héroe Fundador y el culto heroico al antepasado en Hispania y en la Keltiké, Bibliotheca Archaeologica Hispana 36, Madrid.

Almagro-Gorbea, M. y Ruiz Zapatero, G., 1993: “Paleoetnología de la Península Ibérica. Reflexiones y perspectivas de futuro", M. Almagro-GorbeA y G. RuIZ ZAPATERo (eds), Paleoetnología de la Península Ibérica, Complutum, 2-3, 469-499, Madrid.

Almagro-GorbeA, M. Y TORRES, M., 1999: Las fíbulas de jinete y de caballito. Aproximación a las elites ecuestres y su expansión en la Hispania céltica, Zaragoza.

Almagro-Gorbea, M. y TORRes, M., 2008: "Los escarabeos fenicios de Portugal. Un estado de la cuestión", en Estudos Arqueológicos de Oeiras 17, Volume comememorativo do XX aniversario do Centro de Estudos Arqueologicos do Concelho de Oeiras, 1988-2008, 521554, Oeiras.

Almagro-Gorbea, M. y Torres, M., 2010: La escultura fenicia en Hispania, Bibliotheca Archaeologica Hispana, Madrid.

ARrudA, A. M., 2002: Los Fenicios en Portugal. Fenicios e indígenas en el centro y sur de Portugal (siglos VIII-VI a.C.), Barcelona.

ARRIBAS, A. y WiLKINS, J., 1969: “La necrópolis fenicia del Cortijo de las Sombras (Frigiliana, Málaga)", Pyrenae, $5,185-244$. 
ArTeAga, O., PAdró, J. y SANMARTí, E., 1990: El poblado ibérico del Tossal del Moro de Pinyeres (Batea, Terra Alta, Tarragona), Barcelona.

BARNETT, R. D., 1957: A Catalogue of the Nimrud Ivories with other examples of Near Eastern Ivories in the British Museum, London.

BARnett, R. D. y Mendleson, C. (eds.), 1987: Tharros. A Catalogue of the Material in the British Museum from Phoenician and Other Tombs at Tharros, Sardinia, British Museum Publications, London.

Bartoloni, G., Delpino, F., Morigi-Govi, C. y SassateLLI, G. (eds.), 2000: Principi etruschi tra Mediterraneo ed Europa (catálogo de exposición), Bolonia.

BEA, D., 1996: Can Canyís. Una necròpolis de la primera edat del ferro al Penedès, Tesis de licenciatura inédita de la Universidad de Barcelona, Barcelona.

Belén, M; AngladA, R., Escacena, J.L., JimÉnez, A., Lineros, R. y Rodríguez, I. (1997): Arqueología en Carmona (Sevilla). Excavaciones en la Casa-Palacio del Marqués de Saltillo, Sevilla.

BENOIT, F., 1957: Entremont. Capitale celto-ligure des Salyens de Provence, Aix-en-Provence.

BENOIT, F., 1965: Recherches sur l'hellénisation du Midi de la Gaule, Publication des Annales de la Faculté des Lettres, Nouvelle Série n ${ }^{\circ} 43$, Aix-en-Provence - Paris.

BERGES, D., 1998: "Los sellos de arcilla del archivo del templo cartaginés", en M. VeGAS (ed.), Cartago feniciopúnica: las excavaciones alemanas en Cartago 19751997, Cuadernos de Arqueología Mediterránea 4, 111132, Barcelona.

Bienes CAlvo, J. J., 1996: "La necrópolis de El Castejón, Árguedas", Trabajos de Arqueología Navarra, 12, 308-309.

Bissing, F. W. VON, 1951: "Naukratis", Bulletin de la Société Royale d'Archéologie d'Alexandrie, 39, 32-82.

BITTEL, K., 1976: Los Hititas, Madrid.

Blanco FreiJeIro, A., 1987: "Las esculturas de Porcuna I. Estatuas de guerreros", Boletín de la Real Academia de la Historia, CLXXXIV, 405-445.

BLÁNQUEZ, J. y BELÉN, M., 2003: “Cerámicas orientalizantes del Museo de Cabra (Córdoba)", en J. BLÁNQUEZ (ed.), Cerámicas orientalizantes del Museo de Cabra, 81-145, Madrid.

BLÁzQUEZ, J. Ma, 1975: Tartessos y los inicios de la colonización fenicia en Occidente, Acta Salmanticensia 85, Salamanca.

BoARDMAn, J., 1968: Engraved Gems: The Ionides Collection, London.

BOARDMAN, J., 1970: Greek Gems and Finger Rings: Early Bronze Age to Late Classical, London.

BOARDMAN, J., 1975: Intaglios and Rings. Greek, Etruscan and Eastern from a private collection. London.

BOARDMAN, J., 1984: Escarabeos de piedra procedentes de Ibiza, Catálogos y monografías del Museo Arqueológico Nacional, 8, Madrid.

BoArdman, J., 2003: Classical Phoenician Scarabs. A catalogue and study, BAR-International Series 1190, Studies in Gems and Jewellery, II, Oxford.

BOARDMAN, J., DÖRING, J., FUCHS, W. y HIRMER, M., 1967: The Art and Architeture of Ancient Greece, London.
BoARdMan, J., WollenWIEDER, M. L., 1978: Catalogue of the engraved gems and finger rings, Ashmolean $\mathrm{Mu}-$ seum, Oxford.

Bofarull, B.,1992: "Víctor Català i Empúries", en E. PRAT y P. Vila (eds.): Actes de les Primeres Jornades d'Estudi sobre vida i obra de Caterina Albert i Paradís, (1'Escala 9-11 abril 1992), Biblioteca Abat Oliva, Publicacions Abadia de Montserrat.

BONSOR, G., 1928: Early Engraved Ivories in the Collection of the Hispanic Society of America, New York.

Boschloos, V., 2006: Scarabée figurant un sphinx couché. E. WARMENBOL (ed.), Sfinx. De wachters van Egypte (catálogo de exposición), 231, nº 91, Brussel.

BoTET, J., J., 1875: Empúries, notícia histórico-arqueológica de Emporion, Madrid.

Botet, J., 1908: Data aproximada en que els Grecs s'establiren a Empúries i estat de cultura dels naturals del país en realitzar-se aquell establiment (sic), Discurso... leído en la Real Academia de Buenas Letras, Gerona.

Bothmer, D. VON, 1985: The Amasis Painter and His World. Vase Painting in Sixth-Century B.C. Athens, Malibu.

CABRERA, P., 1988-89: "El comercio foceo en Huelva: cronología y fisonomía”, J. FERNÁNDEZ JURADO (ed.), Tartessos y Huelva, Huelva Arqueológica, X-XI, 1-3, 41-100.

CAMPO, M., 1976: Las monedas de Ebusus, Barcelona.

CANÓS, I., 2002: L'epigrafia grega a Catalunya, Hungarian Polis Studies 9, Debrecen.

CAPriotti-VitTOZZI, G., 1999a: "352. Skarabäus", en L. FRANCHI DELl'OrTo (ed.), Die Picener. Ein Volk Europas, (catálogo de exposición), 231, Frankfurt.

CAPRIOTTI-VitTOZZI, G., 1999b: "353. Skarabäus", en L. FrANChi DELl'OrTo (ed.), Die Picener. Ein Volk Europas, (catálogo de exposición), 231-232, Frankfurt.

CATÁLOGO, 1867: Catálogo de la exposición retrospectiva de obras de pintura, de escultura y de artes suntuarias, celebrada por la Academia de Bellas Artes, junio 1867, Barcelona.

Celestino, S., 2001: Cancho Roano, Madrid.

Celestino, S., JiméneZ-Ávila, J. (eds.), 2005: El Período Orientalizante. Actas del III Simposio Internacional de Arqueología de Mérida: Protohistoria del Mediterráneo Occidental, Anejos de Archivo Español de Arqueología 35, Mérida.

CHAPA, T., 1980: La escultura zoomorfa ibérica en piedra, Tesis Doctoral, Universidad Complutense, Madrid.

CHAPA, T., 1986: Influjos griegos en la escultura zoomorfa ibérica, Madrid.

ChÉHAB, M., 1975: "Les Phéniciens au Proche Orient”, Les Phéniciens, 25-142, Paris.

Clausell, G., 1999: "La incineración 20 de la necrópolis del Torrelló del Boverot d'Almassora (Castellón)", en Actas del XXV Congreso Nacional de Arqueología, 495500 , Valencia.

Clausell, G., 2002-2003: "Un escarabeo estrusco en la necrópolis del Torrelló del Boverot (Almazora, Castellón)", Quaderns de Prehistòria i Arqueologia de Castelló, 23, 241-246. 
ColonnA, G., 2002: Il santuario di Portonaccio a Veio. I. Gli scavi di Massimo Pallottino nella zona dell'altare (1939-1940), Monumenti Antichi LVIII, Serie Miscellanea VI.3, Roma.

CONDE, M., 2003: "Escarabeos y amuletos procedentes de Cancho Roano", en S. CELESTino (ed.), Cancho Roano VIII. Los Materiales Arqueológicos I, 231-260, Badajoz.

CUliCAN, W., 1961: "Melqart representations on Phoenicians Seals", Abr-Nahrain, 6, 41-54.

CULICAN, W., 1972: "Phoenician remains from Gibraltar", Australian Journal of Biblical Archaeology, 1.5, 110-145.

CulicAn, W., 1976: “Baal on a Ibiza Gem”, Rivista di Studi Fenici, 4, 57-68.

CULICAN, W., 1986a: Opera selecta, Göteborg.

CULICAN, W., 1986b: "The Iconography of Some Phoenician Seals and Seals Impressions", Opera selecta, 50103, Göteborg.

DE MARININS, R. C., 2007: "L'ambra in Italia settentrionale tra Alpi e Po durante l'età del bronzo", en M. L. NAVA y A. SALERNO (eds.), Ambre, trasparenze dall'antico, (MAN-Napoli, 26 marzo - 10 settembre 2007), 60-67, Nápoles.

DEDET, B., 2008: Les enfants dans la société protohistorique. L'exemple du sud de la France, Collection de l'École Française de Rome, 396, Roma.

Demangel, R., 1935: “Un scarabée androcéphale de Ramsès III à Murviel-lès-Montpellier", Monspeliensia, II.1, $1-6$.

Duplouy, A., 2006: Le prestige des élites. Recherches sur les modes de reconnaissance sociale en Grèce entre les Xe et Ve siècles avant J.-C. Histoire - Les Belles lettres, Paris.

ELES, P. VON (ed.), 2002: Guerriero e sacerdote. Autorità e comunità nell'età del ferro a Verrucchio. La Tomba del Trono, Quaderni di Archeologia dell'Emilia Romagna, 6, Bolonia.

ENGELBACH, R., 1915: Riqque and Mephis VI, London.

FANTAR, M., 1966: "Le cavalier punique de Kerkouane", Africa, 1, 19-39.

FARNIÉ, C. y QUESADA, F., 2005: Espadas de hierro, grebas de bronce. Símbolos de poder e instrumentos de guerra a comienzos de la Edad del Hierro en la Península Ibérica, Serie Monografías del Museo de Arte Ibérico de El Cigarralejo 2, Murcia.

FARO, J. A., CAÑADA, F. y UnZU, M., 2003: "Necrópolis de El Castillo (Castejón, Navarra): Primeras valoraciones, Campañas 2000, 2001, 2002", Trabajos de Arqueología Navarra, 16, 45-77.

FERnÁndez Gómez, J. y MezQuidA, A., 2011: "Una incineración excepcional arcaica en urna lítica de la necrópolis de Puig des Molins", Los púnicos de Iberia: proyectos, revisiones, síntesis, Mainake 22,1, 499-523, Málaga.

FERNÁNDEZ, J. H. y PADRÓ, J., 1982: Escarabeos del Museo Arqueológico de Ibiza, Trabajos del Museo Arqueológico de Ibiza, 7, Ibiza.

FERRER, E., 1991: "Notas aclaratorias sobre el escarabeo de la ría de Huelva", Habis, 22, 411-416.
FLETCHER, D., 1965: La necrópolis ibérica de La Solivella (Alcalá de Xivert, Castellón), Trabajos Varios del S.I.P., 32, Valencia.

FurTwÄNGLER, A., 1900: Die Antiken Gemmen Geschichte der Steinschneidekunst im Klassischn Alterum, Leipzig - Berlin.

GAllet DE SANTERre, H., 1964: "Montpellier", Gallia, 22.2, 473-509.

Gallet De SANTERRE, H., 1962: "Circonscription de Montpellier", Gallia, 20.2, 611-640.

GAMER-WALLERT, I., 1973: "Der Skarabäus vom Cabezo de la Joya in Huelva”, Madrider Mitteilungen 14, 121-126.

GAMER-WALLERT, I., 1975: "Consideraciones sobre el escarabeo de Frigiliana (Málaga)”, Pyrenae, 11, 63-70.

GAMER-WALLERT, I., 1977: "Ein neuer Skarabäus vom Jardín bei Torre del Mar”, Madrider Mitteilungen, 18, 98-100.

GAMER-WALLERT, I., 1978: Ägyptische und ägyptisierende Funde von der Iberischen Halbinsel, Beihefte zum Tübinger Atlas des Vorderen Oriens, Reihe B, Nr. 21, Wiesbaden.

GAMER-WALLERT, I., 1982: "Der neue Skarabäus aus Alcácer do Sal”, Madrider Mitteilungen, 23, 96-100.

GAMER-WALlert, I. y CAVAlEIRO-PAIXÃO, A., 1983: “A inscrição do escaravelho de Psamético I, da necrópole do Olival do Senhor dos Mártires. Novos elementos para sua interpretação", O Arqueólogo Português, Série IV, 1, 267-272.

GARBINI, G., 1993: "La dea di Tharros", Rivista di Studi Fenici, XXI, 99-110.

GARcíA Alfonso, E., 1998: "El cilindro-sello de VélezMálaga”, Madrider Mitteilungen, 39, 49-97.

GARCÍA GANDÍA, J. R., 2005: "La necrópolis orientalizante de les Casetes. Ajuares y estructuras funerarias". L. ABAD, F. SALA e I. GRAU (eds.): La Contestania Ibérica, 30 años después, 345-355, Alicante.

GARCÍA GANDÍA, J. R., 2009: La necrópolis orientalizante de Les Casetes (La Vila Joiosa, Alicante), Alicante.

GARCÍA-CANO, J. M., 1997: La necrópolis de Coimbra del Barranco Ancho (Jumilla, Murcia). I. Las excavaciones y estudio analítico de los materiales, Murcia.

Garcia i Roselló, J., 1993: Turó dels Dos Pins. Necròpolis ibèrica, Mataró.

Garcia MartíneZ, M. A., 2001: Documentos Prerromanos de tipo egipcio de la vertiente atlántica hispano-mauritana, Orientalia Monspeliensia, XIII, Montpellier.

GARDNER, E. A., 1888: Naukratis, II. London.

GAUTHIER, H., 1916: Le livre des rois d'Égypte. IV, De la $X X V^{e ̀ m e}$ dynastie à la fin des Ptolémées, I.F.A.O. 20, Le Caire.

GENTILI, G.V., 2003: Verucchio villanoviana. Il sepolcreto in Località Le Pegge e la necropoli al piede della Rocca Malatestiana, Monumenti Antichi, vol. 59 - Serie monografica vol. 6, Roma.

Giovanelli, E., 2010: “A proposito di uno scarabeo da Colle del Forno: alcune considerazioni sulla produzione di stile globulare", LANX, 5, 208-216.

GIVEON, R., 1985: Egyptian scarabs from western Asia from the Collections of the British Museum, Orbis Biblicus et Orientalis, Series Archaeologica, 3, Friburg. 
GJERSTAD, E. ET ALII, 1935: The Swedish Cyprus Expedition. Finds and Results of the Excavation in Cyprus 1927-1931, Vol. II, Estokholm.

GORTON, A. F., 1996: Egyptian and Egyptianizing Scarabs, A typology of steatite, faience and paste scarabs from Punic and other Mediterranean sites, Oxford University Committee for Archaeology, Mongraph 44, Oxford.

GRAELLS, R., 2008: La necrópolis protohistórica de Milmanda (Vimbodí, Conca de Barberà, Tarragona). Un exemple del món funerari català durant el trànsit entre els segles VII $i$ VI aC., Hic et Nunc 5, Tarragona.

GRAELLS, R., 2009a: Análisis de las manifestaciones funerarias en Catalunya durante los ss. VII y VI aC. Sociedad y Cultura Material: la asimilación de estímulos mediterráneos (26 enero de 2009), http://hdl.handle. net/10803/8217

GRAELLS, R., 2009b: "Les enfants dans la société protohistorique. L'exemple du sud de la France", por Bernard Dedet, Collection de l'École Française de Rome, 396, Revista d'Arqueologia de Ponent, 19, 408-410.

GRAELLS, R., 2010: Las tumbas con importaciones y la recepción del Mediterráneo en el nordeste de la Península Ibérica (siglos VII-VI aC), Revista d'Arqueologia de Ponent-Extra 1, Lleida.

GRAELls, R., 2011: Dactyliothecae cataloniae. El col-leccionisme de glíptica a Catalunya abans de 1900, Espai / Temps, 58, Lleida.

Green, M., 1992: Dictionary of Celtic Myth and Legend, Singapore.

GrIfFITH, F. L., 1888: en W. N. F. Petrie, Tanis II, London.

GRIFFITH, F. L., 1923: “Oxford Excavations in Nubia”, Liverpool Annals of Archaeology and Anthropology, 10,34, 73-171.

GRUMMOND, N. T., 2010: "A Scarab Gem from the Etruscan Artisans' Quarter and Sacred Area at Cetamura del Chianti”, Rasenna. Journal of the Center for Etruscan Studies, 2, 1-24.

Gubel, E., 1987: Phoenician Furniture. A Typology based on Iron Age Representations with Reference to the Iconographical background, Leuven.

GuIRAuD, H., 1973: "Pierres gravées de la collection Charra", Bulletin Comm. Arch. Narbonne, 35, 175-190.

GUIRAUD, H., 1980: "Quelques remarques sur la glyptiques en Gaule du Sud aux derniers siècles avant notre ère", Pallas, 27, 69-87.

GUIRAUD, H., 1988: Intailles et camées de l'époque romaine en Gaule (territoire français), Suppl. Gallia, 48, Paris.

Hall, H. R., 1913: Catalogue of Egyptian Scarabs, \&c., in the British Museum, I, Royal Scarabs, London.

HANSSON, U. R., 2005: A Globolo Gems: Late Etrusco-italic Scarab Intaglios, Göteborg.

HENIG, M., 1970 "The Veneration of Heroes in the Roman Army: The Evidence of Engraved Gemstones", Britannia, 1, 249-265.

HodJAsH, S., 1999: Ancient Egyptian Scarabs, Ed. Vostochnaya Literatura, Moscú.

HoGARTH, D. G., 1898-1899: "Excavations at Naukratis", Annual of the British School at Athens, 5, 26-97.
Hogarth, D. G., Lorimer, H. L. y EdGar, C. C., 1905: "Naukratis 1903", Journal of Hellenic Studies, 25, $105-136$

HöLBL, G., 1979: Beziehungen der ägyptischen Kultur zu Altitalien, Leiden.

HöLBL, G., 1986: Ägyptisches Kulturgut in phönizischen und punischen Sardinien, Leiden.

HorTA, M. A., 1975: "Objectos egípcios do porto do Sabugueiro (Muge)", Conimbriga, XIV, 173-175.

JAEGER, B., 1982: Essai de classification et datation des scarabées Menkhéperrê, Fribourg.

JAMES, P., 2003: "Naukratis revisited", Hyperboreus, Studia Classica, 9.2, 235-264.

JAMES, T. H. G., 1962: "The egyptian-type objects", en T. J. Dunbabin (ed.), Perachora, the Sanctuaries of Hera Akraia and Limenia. Excavations of the British School of Archaeology at Athens, 1930-1933, II, Pottery, Ivories, scarabs, and other objects from the votive deposit of Hera Limenia, Oxford.

JANIN, Th., 2008: "Lattes, Saint-Sauveur", Bilan Scientifique de la Région Languedoc-Roussillon - 2005, Service Régional de l'Archéologie, 133-137.

JENKINS, G. K., 1972: Monnaies grecques, Friburg.

KeEL, O., 1972: Die Welt der orientalischen Bildsymbolik und das Alte Testament, Neukirchen.

KEEL, O., 1992: "Ägyptische Baumgöttinnen der 18.-21. Dynastie. Bild und Wort, Wort und Bild. O. Keel”, Das Recht der Bilder gesehen zu werden, Orbis Biblicus et Orientalis 122, 61-138, Freiburg.

KeEL, O., 1998: Goddesses and Tries, New Moon and Yaveh, Journal for the Study of the Old Testament. Supplement Series 261, Sheffild.

KeEL, O. y Ühlinger, C., 1992: Göttinen, Götter und Göttessymbole. Neue Erkenntnissezur zur Religiongeschichte Kanaaans und Israels aufgrund bislang unerloschenner ikonographiker Quellen, Freiburg.

KeEl, O. y Ühlinger, C., 1998: Gods, Goddesses, and Images og God in Ancient Israel, Edinburgh.

KENYON, K.M., 1965: Excavations at Jericho, II, The tombs excavated in 1955-1958, London.

KocH, M., 1984: Tarschisch und Hispanien (Madrider Forschungen 14), Berlin (trad., Madrid, 2004).

LAGARCE, E., 1983: "Le rôle d'Ugarit dans l'élaboration du repertoire iconographique syro-phénicien du premier millénaire avant J.-C.", en Atti I Congresso Internazionale di Studi Fenici e Punici, 547-561, Roma.

LANGLOYS, G., 2000: "Les têtes coupées du Midi de la Gaule et leur contribution au mythe de la barbarie", Bulletin archéologique de Provence, 28, 39-51.

Le Meaux, H., 2005: "Estilos orientalizantes: el caso de los marfiles peninsulares", en El periodo orientalizante, III Simposio Internacional de Arqueología de Mérida, Congreso de Protohistoria del Mediterráneo Occidental, (Mérida-2003), 1117-1135, Madrid.

LisSARRAGUE, F., 1990: L'autre guerrier. Archers, peltastes, cavaliers dans l'imagerie attique, Paris-Rome.

LÓPEZ DE LA ORDEN, D., 1990: La glíptica de la antigüedad en Andalucía. Cádiz. 
MALlowan, M.E.L. y HerRmann, G. 1974: Forniture from SW.7 Fort Shalmeneser, Ivories from Nimrud III, London.

MALUQUeR DE Motes, J., 1992: “'Cowroid' de cerámica vidriada hallado en el poblado ibérico de "Tossal del Moro" en Piñeras (Batea, Tarragona)". Pyrenae, 22-23, 155-160

MALUQUeR DE Motes, J., 1969: "Los Fenicios en Catalunya”, en V Symposium de Prehistoria Peninsular. Tartessos y sus Problemas (1968), 241-250, Barcelona.

MALUQUeR DE MoTeS, J., 1981: El santuario protohistórico de Zalamea de la Serena, Badajoz, 1: 19781981, Programa de Investigaciones Protohistoricas, 4, Barcelona.

MAluquer de Motes, J., 2000: "Los Fenicios en Cataluña”, Homenatge al Prof. Dr. Joan Maluquer de Motes, Pyrenae, 22-23, Barcelona, 141-149.

MAncebo, J., FerRer, E., 1992: "El escarabeo de Pancorvo, Sevilla", SPAL, 1, 313-320.

MARTELLI, M., 2000: "Le arti minori. Sfragistica e glittica", M. TORELLi (ed.), Gli Etruschi (catalogo de exposición), 455-462, Venezia.

MARRAS, L., 1990: "Un insediamento fluviale fenicio: stato e prospettive", Incontro "I Fenici", 51-58, Cagliari.

MAs, P., RomeU, J. y ARDITE, X., 2008: "Iconografia de la Creu de Vilabertran", Annals de l'Institut d'Estudis Empordanesos, 39, 277-299.

MATTHiae SCANDONE, G., 1975: Scarabei e Scaraboidi egiziani ed egittizzanti del Museo Nazionale di Cagliari, Roma.

MelandRI, G., 2010: “Aegyptiaca a Capua nel quadro dei traffici col mondo vicino-orientale tra età del Ferro e Orientalizzante", Bollettino di Archeologia on line I 2010/, Volume speciale F / F3 / 3, 20-32.

MIARI, M., 2007: "L'ambra in area terramaricola", en M. L. NAVA y A. SALERno (eds.), Ambre, trasparenze dall'antico (catálogo de exposición), 68-72, Nápoles.

MolinA, F., RUIZ, A. y HuERTAS, C., 1982: Almuñecar en la antigüedad. La necrópolis fenicio-púnica de Puente de Noy, Granada.

NAS, P., 1992: “s.v. Numismatique”, en E. LIPINSKI (ed.), Dictionnaire de la civilisation phénicienne et punique, 320-321, Bruxelles.

NAVA, M.L., SALERNO, A., 2007: 'L'ambra nell'Italia centro-meridionale peninsulare durante l'età del bronzo", in M. L. NAVA y A. SALERNO (eds.): Ambre, trasparenze dall'antico (catálogo de exposición), 82-87, Nápoles.

NÉMETH, G., 2007: "Intailles et camées avec inscriptions grecques à Catalogne", Acta XII Congrés Internationale d'Epigraghie Grecque et Latine, 1007-1012, Barcelona.

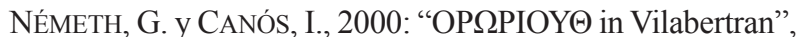
Zeitschrift für Papyrologie und Epigraphik, 130, 139-142.

NEWBERRY, P. E., 1906: Egyptian antiquities. Scarabs. An introduction to the study of Egyptian seals and signet rings, London.

NEWBERry, P. E., 1907: Scarab-shaped-seals. Catalogue Général des Antiquités Egyptiennes du Musée du Cairo, 32, London.
Olcina, M. H. Y RAmón, J. J., 2010: Objetos egipcios en Alicante (catálogo de exposición), Alicante.

Oliver, A., 1999: “Avance de las campañas de 1996-1999 en el yacimiento ibérico del Puig de la Nau (Benicarló, Baix Maestrat)", Quaderns de Prehistòria i Arqueologia de Castelló, 20, 351-358.

Oliver, A., 2007: El Puig de la Nau, Benicarló, Castellón.

Oliver, A. y Gusi, F., 1995: El Puig de la Nao. Un hábitat fortificado ibérico en ámbito ibérico mediterráneo peninsular, Castellón.

OLMOS, R., 1983: "El centauro de Rollos y el centauro en el mundo ibérico”, Homenaje al Prof. Martín Almagro Basch, II, 377-388, Madrid.

Olmos, R., 2002: "Los grupos escultóricos del Cerrillo Blanco de Porcuna (Jaén). Un ensayo de lectura iconográfica convergente", Archivo Español de Arqueología, 75, 107-122.

PADRÓ I PARCERISA, J., 1971: "Breus notes sobre els escarabeus i escaraboids de la necròpolis de Can Canyís", Pyrenae, 7, 129-133.

PADRÓ I PARCERISA, J., 1971-1972: "Un escarabeo de ámbar procedente de las excavaciones de Rhode (Roses)", Ampurias, 33-34, 293-295.

PADRÓ I PARCERISA, J., 1974a: “A propósito del escarabeo de la Solivella (Alcalá de Xivert, Castellón) y de otras piezas egipcias del Bajo Ebro", Cuadernos de Prehistoria y Arqueología Castellonenses, 1, 71-78.

PADRÓ I PARCERISA, J., 1974b: "Los escarabeos de Emporion”, en Miscelánea Arqueológica, II. XXV Aniversario de los Cursos Internacionales de Prehistoria y Arqueología de Ampurias. Barcelona, 113-125.

PADRÓ I PARCERISA, J., 1976: Los materiales de tipo egipcio del litoral mediterráneo de la Península Ibérica, Barcelona.

PADRÓ I PARCERISA, J., 1976-1978: "Datos para una valoración del factor egipcio y de su incidencia en los orígenes del proceso de iberización", Ampurias 38-40, 487-510.

PADRÓ I PARCERISA, J., 1980: Egytian-type documents from the mediterranean littoral of the Iberian Peninsula before the roman conquest, I. Introductory Surrey, Leiden.

PADRÓ I PARCERISA, J., 1982-1983: "De nuevo sobre los hallazgos egipcios y egiptizantes de la Península Ibérica", Cuadernos de Prehistoria y Arqueología Castellonenses, 9, 149-191.

PADRÓ I PARCERISA, J., 1983: Egytian-type documents from the mediterranean littoral of the Iberian Peninsula before the roman conquest, II. Study of the material: From Western Languedoc to Murcia, Leiden.

PADRÓ I PARCERISA, J., 1985: Egytian-type documents from the mediterranean littoral of the Iberian Peninsula before the roman conquest, III. Study of the material: Andalusia, Leiden.

PADRÓ I PARCERISA, J., 1991: “Un joiell d'argent egiptitzant del puig de la Nau de Benicarló". Cuadernos de Prehistoria y Arqueología Castellonenses, 15, 443-446.

PADRÓ I PARCERISA, J., 2000: “Sobre la publicación "Los Fenicios en Cataluña"', Pyrenae, 22-23, Homenatge al Prof. Dr. Joan Maluquer de Motes, 151-153. 
PADRÓ I PARCERISA, J., 2002-2003: "Una función apotropaica de los amuletos de tipo egipcio en el mundo prerromano hispánico", Cuadernos de Prehistoria y Arqueología Castellonense, 23, 247-249.

PADRÓ I PARCERISA, J., 2010: "Un scarabée punique découvert à Lattes", Lattara, 21, 757-758.

PANCRAZZI, O., 1979: Cavallino, Pubblicazzione del Dipartimento di Beni Culturali dell'Università di LecceSettore Storico Archeologico, 2, Lecce.

Perdigones, L.; BALIÑA, R., 1987: "Excavaciones de urgencia en un solar de la $\mathrm{C} /$ Tolosa Latour (Cádiz) en 1985”, en Anuario Arqueológico de Andalucía 1985 / III Actividades de Urgencia, 63-70, Sevilla.

Perdigones, L., MuÑoz, A. y PisAno, G., 1990: La necrópolis fenicio-púnica de Cádiz. Siglosd VI-IV a. de C., Studia Punica 7) Roma.

PernigotTi, S., 1979: "Nota. Scarabeo della tomba CV.1", en O. PANCRAZI (ed.), Cavallino, 227-229, Lecce.

Petrie, W. M. F., 1886: Naukratis, I, London.

Petrie, W. M. F., 1889: Historical Scarabs, London.

Petrie, W. M. F., 1914: Amulets, London.

Petrie, W. M. F., 1917: Scarabs and Cylinders with Names. London.

Petrie, W. M. F., 1925: Buttons and Design Scarabs, London.

PISANO, G., 1978: "Dieci scarabei da Tharros", Rivista di Studi Fenici, 6, 37-56.

PISANO, G., 1996: "L'iconografia del cavaliere, nella glittica punica", en E. ACQUARO (ed.), ALLE SOGLIE DELLA CLASSICITÀ. Il Mediterraneo tra tradizione e innovazione, Studi in onore di Sabatino Moscati, II, 917-924, Pisa-Roma.

Pujol, C., 1890: "Un anillo ibérico", Boletín de la Real Academia de la Historia, 16, 165-169.

PY, M., 2009: Lattara. Lattes, Hérault. Comptoir gaulois méditerranéen entre Étrusques, Grecs et Romains, Paris.

RADDATZ, K. 1969: Die Schatzfunde der Iberischen Halbinsel, Madrider Forschungen 5, Berlín.

RichTER, G. M. A., 1956: Catalogue of Engraved Gems Greek, Etruscan and Roman, Roma.

Richter, G. M. A., 1968: Engraved Gems of the Greeks and Etruscans, A History of Greek Art in Miniature, London.

RicOMÀ, R. M., 1982: Les gemmes del Museu Nacional Arqueològic de Tarragona, Tarragona.

RIDDER, A. de, 1911: Collection de Clercq, VII.2, Paris.

RODÀ, I., 2010: "Las gemas de Tarraco. Iconografía e identificación de los materiales", Histria Antiqua, 19, 37-46.

Roulin, E., 1899: Monuments et mémoires, VI, 201-214.

SANMARTÍ, J., 1994: "Eléments de type laténièn au nord-est de la Péninsule Ibérique", L'Age du Fer en Europe sudoccidentale, Actes du XVIe Colloque de l'Association
Française pour l'Etude de l'Age du Fer (Agen-1992), Aquitania, XII, 336-351.

SCHAEFFER, Cl. F.-A., 1949: Ugaritica II, Paris.

SCHUBART, H., y MAASS-LindeMANN, G., 2007: Toscanos. Die phönizische Niederlasung an der Mündung des río de Vélez. 2. Grabungskampagnen in Toscanos, Alarcón und Jardín, Madrider Forschungen 6, 2, Berlin.

SenA-ChiesA, G., 1966: Gemme del Museo Nazionale di Aquileia, Padova.

SOLIER, Y., 1960: "Les fouille de Peyriac-de-Mer", Bulletin de la Société d'Études Scientifiques de l'Aude, 61.

SPIER, J., 1992: Ancient gems and finger rings: catalogue of the collections, J. Paul Getty Museum Catalogs, 3, Kyoto.

TORELLI, M., 2002: “Autorappresentarsi. Immagine di sé, ideologia e mito greco attraverso gli scarabei etruschi", Ostraka, 11.1, 101-155.

TORRES, M., 2002: Tartessos, Madrid.

TRIAS, G., 1967-1969: CERÁMICAS GRIEGAS DE LA PENÍNSULA IBÉRICA, VALENCIA.

UNZU, M., y FARO, J. A., 2006: "La necrópolis de la Edad del Hierro de El Castillo (Castejón, Navarra). Primeras valoraciones: campañas 2000-2002", Complutum, 17, 145-166.

UROZ, H., 2006: El programa iconográfico religioso de la "tumba del orfebre" de Cabezo Lucero (Guardamar del Segura, Alicante), Monografías del Museo de Arte Ibérico de El Cigarralero, 3, Murcia.

VERCOUTTER, J., 1945: Les objets Egyptiens et Egyptisants du Mobilier Funéraire Carthaginois, Paris.

VilaseCA, S., SolÉ, J. M. y MAÑé, R., 1963: La necrópolis de Can Canyís (Banyeres. prov. de Tarragona), Trabajos de Prehistoria, 8, Madrid.

VOLLENWEIDER, M. L., 1979: Catalogue raisonné des sceaux, cylindres, intailles et camées. II. Les portraits, les masques de théatre, les symboles politiques: une contribution à l'histoire des civilisations hellénistique et romaine, Mainz am Rhein.

Walters, H. B., 1926: Catalogue of the Engraved Gems and Cameos. Greek, Etruscan and Roman in the British Museum, London.

WeIDIG, J., 2010: Bazzano. Ein Gräberfeld bei l'Aquila (Abruzzen) I. Die Bestattungen des 8-5 Jhs. v. Chr. Untersuchungen zu Chronologie, Bestattungsbräuchen und Sozialstrukturen im apenninischen Mittelitalien (Die Ausgrabungen 1992-2004 einschließlich einiger Fundkontexte der Grabung 2004-2005) (Dissertation im Fachbereich Geschichte und Kulturwissenschaften der Philipps-Universität Marburg), Marburg-Mainz.

ZAZOFF, P., 1968: Etruskische Skarabäen, Mainz am Rhein. ZWIERLEIN-DIEHL, E., 1973: Die antiken Gemmen des Kunsthistorisches Museums im Wien, I, Wien. 